Cochrane Database of Systematic Reviews

\title{
Interventions for treating oral lichen planus: corticosteroid therapies (Review)
}

Lodi G, Manfredi M, Mercadante V, Murphy R, Carrozzo M

Lodi G, Manfredi M, Mercadante V, Murphy R, Carrozzo M.

Interventions for treating oral lichen planus: corticosteroid therapies.

Cochrane Database of Systematic Reviews 2020, Issue 2. Art. No.: CD001168.

DOI: 10.1002/14651858.CD001168.pub3.

www.cochranelibrary.com 
TABLE OF CONTENTS

HEADER

ABSTRACT

PLAIN LANGUAGE SUMMARY

SUMMARY OF FINDINGS

2

BACKGROUND

OBJECTIVES

METHODS

RESULTS

Figure 1.

Figure 2.

Figure 3.

DISCUSSION

AUTHORS' CONCLUSIONS

ACKNOWLEDGEMENTS

REFERENCES

CHARACTERISTICS OF STUDIES

DATA AND ANALYSES

Analysis 1.1. Comparison 1 Corticosteroids versus placebo, Outcome 1 Pain score.

Analysis 1.2. Comparison 1 Corticosteroids versus placebo, Outcome 2 Pain resolution.

Analysis 1.3. Comparison 1 Corticosteroids versus placebo, Outcome 3 Clinical score.

Analysis 1.4. Comparison 1 Corticosteroids versus placebo, Outcome 4 Clinical resolution.

Analysis 1.5. Comparison 1 Corticosteroids versus placebo, Outcome 5 Adverse effects.

Analysis 2.1. Comparison 2 Corticosteroids versus calcineurin inhibitors, Outcome 1 Pain score.

Analysis 2.2. Comparison 2 Corticosteroids versus calcineurin inhibitors, Outcome 2 Pain resolution.

Analysis 2.3. Comparison 2 Corticosteroids versus calcineurin inhibitors, Outcome 3 Clinical score.

Analysis 2.4. Comparison 2 Corticosteroids versus calcineurin inhibitors, Outcome 4 Clinical resolution.

Analysis 2.5. Comparison 2 Corticosteroids versus calcineurin inhibitors, Outcome 5 Adverse effects.

Analysis 3.1. Comparison 3 Corticosteroid A versus corticosteroid B, Outcome 1 Pain score.

Analysis 3.2. Comparison 3 Corticosteroid A versus corticosteroid B, Outcome 2 Pain resolution.

Analysis 3.3. Comparison 3 Corticosteroid A versus corticosteroid B, Outcome 3 Clinical score.

Analysis 3.4. Comparison 3 Corticosteroid A versus corticosteroid B, Outcome 4 Clinical resolution.

Analysis 3.5. Comparison 3 Corticosteroid A versus corticosteroid B, Outcome 5 Adverse effects.

Analysis 4.1. Comparison 4 Corticosteroids versus other treatments, Outcome 1 Pain score.

Analysis 4.2. Comparison 4 Corticosteroids versus other treatments, Outcome 2 Pain score (split-mouth study).

Analysis 4.3. Comparison 4 Corticosteroids versus other treatments, Outcome 3 Pain resolution.

Analysis 4.4. Comparison 4 Corticosteroids versus other treatments, Outcome 4 Clinical score.

Analysis 4.5. Comparison 4 Corticosteroids versus other treatments, Outcome 5 Clinical score (split-mouth study). ................

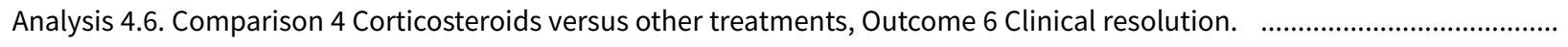

Analysis 4.7. Comparison 4 Corticosteroids versus other treatments, Outcome 7 Clinical Resolution (split-mouth study). ........

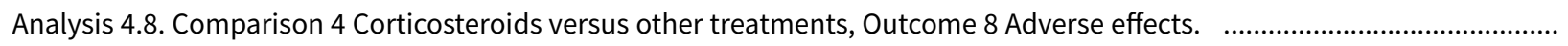

Analysis 4.9. Comparison 4 Corticosteroids versus other treatments, Outcome 9 Adverse events (split-mouth study). .............

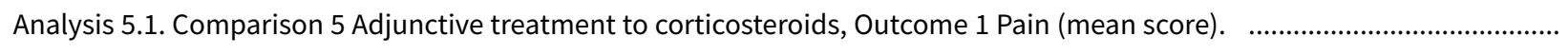

Analysis 5.2. Comparison 5 Adjunctive treatment to corticosteroids, Outcome 2 Clinical score.

Analysis 5.3. Comparison 5 Adjunctive treatment to corticosteroids, Outcome 3 Clinical resolution.

Analysis 5.4. Comparison 5 Adjunctive treatment to corticosteroids, Outcome 4 Adverse effects.

ADDITIONAL TABLES

APPENDICES

WHAT'S NEW

HISTORY 
[Intervention Review]

\title{
Interventions for treating oral lichen planus: corticosteroid therapies
}

\author{
Giovanni Lodi ${ }^{1}$, Maddalena Manfredi², Valeria Mercadante ${ }^{3}$, Ruth Murphy ${ }^{4}$, Marco Carrozzo 5
}

1Department of Biomedical, Surgical and Dental Sciences, University of Milan, Milan, Italy. ${ }^{2}$ Polo Clinico di Odontostomatologia, SBiBiT Department, University of Parma, Parma, Italy. ${ }^{3}$ Eastman Dental Institute, University College of London, London, UK. ${ }^{4}$ Department of Dermatology, Sheffield Children's Hospital, Sheffield Children's NHS Foundation Trust, Sheffield, UK. 5Department of Oral Medicine, School of Dental Sciences, University of Newcastle upon Tyne, Newcastle upon Tyne, UK

Contact address: Marco Carrozzo, Department of Oral Medicine, School of Dental Sciences, University of Newcastle upon Tyne, Framlington Place, Newcastle upon Tyne, NE2 4BW, UK. marco.carrozzo@ncl.ac.uk.

Editorial group: Cochrane Oral Health Group.

Publication status and date: New search for studies and content updated (conclusions changed), published in Issue 2, 2020.

Citation: Lodi G, Manfredi M, Mercadante V, Murphy R, Carrozzo M. Interventions for treating oral lichen planus: corticosteroid therapies. Cochrane Database of Systematic Reviews 2020, Issue 2. Art. No.: CD001168. DOI: 10.1002/14651858.CD001168.pub3.

Copyright @ 2020 The Cochrane Collaboration. Published by John Wiley \& Sons, Ltd.

\section{A B S T R A C T}

\section{Background}

Oral lichen planus (OLP) is a relatively common chronic T cell-mediated disease, which can cause significant pain, particularly in its erosive or ulcerative forms. As pain is the indication for treatment of OLP, pain resolution is the primary outcome for this review. This review is an update of a version last published in 2011, but focuses on the evidence for corticosteroid treatment only. A second review considering non-corticosteroid treatments is in progress.

\section{Objectives}

To assess the effects and safety of corticosteroids, in any formulation, for treating people with symptoms of oral lichen planus.

\section{Search methods}

Cochrane Oral Health's Information Specialist searched the following databases to 25 February 2019: Cochrane Oral Health's Trials Register, CENTRAL (2019, Issue 1), MEDLINE Ovid, and Embase Ovid. ClinicalTrials.gov and the World Health Organization International Clinical Trials Registry Platform were searched for ongoing trials. There were no restrictions on language or date of publication.

\section{Selection criteria}

We considered randomised controlled clinical trials (RCTs) of any local or systemic corticosteroid treatment compared with a placebo, a calcineurin inhibitor, another corticosteroid, any other local or systemic (or both) drug, or the same corticosteroid plus an adjunctive treatment.

\section{Data collection and analysis}

Three review authors independently scanned the titles and abstracts of all reports identified, and assessed risk of bias using the Cochrane tool and extracted data from included studies. For dichotomous outcomes, we expressed the estimates of effects of an intervention as risk ratios (RR), with 95\% confidence intervals (CI). For continuous outcomes, we used mean differences (MD) and 95\% Cl. The statistical unit of analysis was the participant. We conducted meta-analyses only with studies of similar comparisons reporting the same outcome measures. We assessed the overall certainty of the evidence using GRADE.

\section{Main results}

We included 35 studies (1474 participants) in this review. We assessed seven studies at low risk of bias overall, 11 at unclear and the remaining 17 studies at high risk of bias. We present results for our main outcomes, pain and clinical resolution measured at the end of 
the treatment course (between one week and six months), and adverse effects. The limited evidence available for comparisons between different corticosteroids, and corticosteroids versus alternative or adjunctive treatments is presented in the full review.

\section{Corticosteroids versus placebo}

Three studies evaluated the effectiveness and safety of topical corticosteroids in an adhesive base compared to placebo. We were able to combine two studies in meta-analyses, one evaluating clobetasol propionate and the other flucinonide. We found low-certainty evidence that pain may be more likely to be resolved when using a topical corticosteroid rather than a placebo (RR $1.91,95 \% \mathrm{Cl} 1.08$ to $3.36 ; 2$ studies, 72 participants; $I^{2}=0 \%$ ). The results for clinical effect of treatment and adverse effects were inconclusive (clinical resolution: RR 6.00, 95\% $\mathrm{Cl} 0.76$ to 47.58 ; 2 studies, 72 participants; $\mathrm{I}^{2}=0 \%$; very low-certainty evidence; adverse effects RR $1.48,95 \% 0.48$ to $4.56 ; 3$ studies, 88 participants, $\mathrm{I}^{2}=0 \%$, very low-certainty evidence).

\section{Corticosteroids versus calcineurin inhibitors}

Three studies compared topical clobetasol propionate versus topical tacrolimus. We found very low-certainty evidence regarding any difference between tacrolimus and clobetasol for the outcomes pain resolution (RR $0.45,95 \% \mathrm{Cl} 0.24$ to $0.88 ; 2$ studies, 100 participants; $\mathrm{I}^{2}=80 \%$ ), clinical resolution (RR $0.61,95 \% \mathrm{Cl} 0.38$ to $0.99 ; 2$ studies, 52 participants; $\mathrm{I}^{2}=95 \%$ ) and adverse effects (RR $0.05,95 \% \mathrm{Cl} 0.00$ to 0.83 ; 2 studies, 100 participants; very low-certainty evidence).

One study (39 participants) compared topical clobetasol and ciclosporin, and provided only very low-certainty evidence regarding the rate of clinical resolution with clobetasol (RR 3.16, 95\% Cl 1.00 to 9.93), pain resolution (RR $2.11,95 \% \mathrm{Cl} 0.76$ to 5.86 ) and adverse effects (RR $6.32,95 \% \mathrm{Cl} 0.84$ to 47.69$)$.

Two studies (60 participants) that compared triamcinolone and tacrolimus found uncertain evidence regarding the rate of clinical resolution (RR $0.86,95 \% \mathrm{Cl} 0.55$ to 1.35 ; very low-certainty evidence) and that there may be a lower rate of adverse effects in the triamcinolone group (RR $0.47,95 \% \mathrm{Cl} 0.22$ to 0.99 ; low-certainty evidence). These studies did not report on pain resolution.

\section{Authors' conclusions}

Corticosteroids have been first line for the treatment of OLP. This review found that these drugs, delivered topically as adhesive gels or similar preparations, may be more effective than placebo for reducing the pain of symptomatic OLP; however, with the small number of studies and participants, our confidence in the reliability of this finding is low. The results for clinical response were inconclusive, and we are uncertain about adverse effects. Very low-certainty evidence suggests that calcineurin inhibitors, specifically tacrolimus, may be more effective at resolving pain than corticosteroids, although there is some uncertainty about adverse effects and clinical response to tacrolimus showed conflicting results.

\section{PLAIN LANGUAGE SUMMARY}

\section{Corticosteroids for treating oral lichen planus}

\section{Review question}

Are corticosteroids effective and safe for the treatment of oral lichen planus that is causing pain?

\section{Background}

Oral lichen planus is a common condition that can cause long-term, painful areas on the lining of the mouth. Usual treatment is with drugs known as corticosteroids applied directly to the painful areas (topically), or taken internally (systemically). Treatment aims to reduce pain and improve healing of the mouth, but there is no cure for the disease.

\section{Study characteristics}

The evidence in this review is up-to-date as of 25 February 2019. We included 35 randomised controlled trials (clinical studies where people are randomly put into one of two or more treatment groups) with 1474 participants, which tested several different corticosteroids, mostly delivered topically (on the skin). Corticosteroids were compared with one of the following: a placebo (a treatment that resembled the corticosteroid but had no active ingredient); a medicine from a category called calcineurin inhibitors; another medicine type; another corticosteroid or mode of delivery; the same corticosteroid plus an extra treatment; or an alternative treatment. Treatments were given for between one week and six months, with side effects measured throughout the treatment, and pain and healing measured at the end of treatment.

\section{Key results}

Results from two studies showed that topical corticosteroids (e.g. clobetasol propionate, flucinonide, betamethasone and triamcinolone acetonide), when applied to the mouth in a sticky cream, may be effective in reducing and stopping pain. We do not have the evidence that topical corticosteroids can eliminate the oral lichen planus lesions, and we are uncertain about side effects. 
We found no consistent evidence that any particular corticosteroid was better than any other.

Three studies using another topical medicine called tacrolimus (a calcineurin inhibitor) found that this medicine may be more effective than corticosteroids, but may be more likely to cause mild side effects.

Available evidence comparing corticosteroids with other treatments is very limited.

\section{Reliability of the evidence}

The reliability of most of the evidence is very low, so we cannot be sure about the findings and future research may lead us to different conclusions.

\section{Conclusion}

The available evidence suggests that topical corticosteroids may be effective for treating painful oral lichen planus, but our confidence in these findings is limited as there were only a small number of studies and participants. There is some evidence that tacrolimus may be more effective than a corticosteroid, but evidence on negative side effects is inconclusive. 


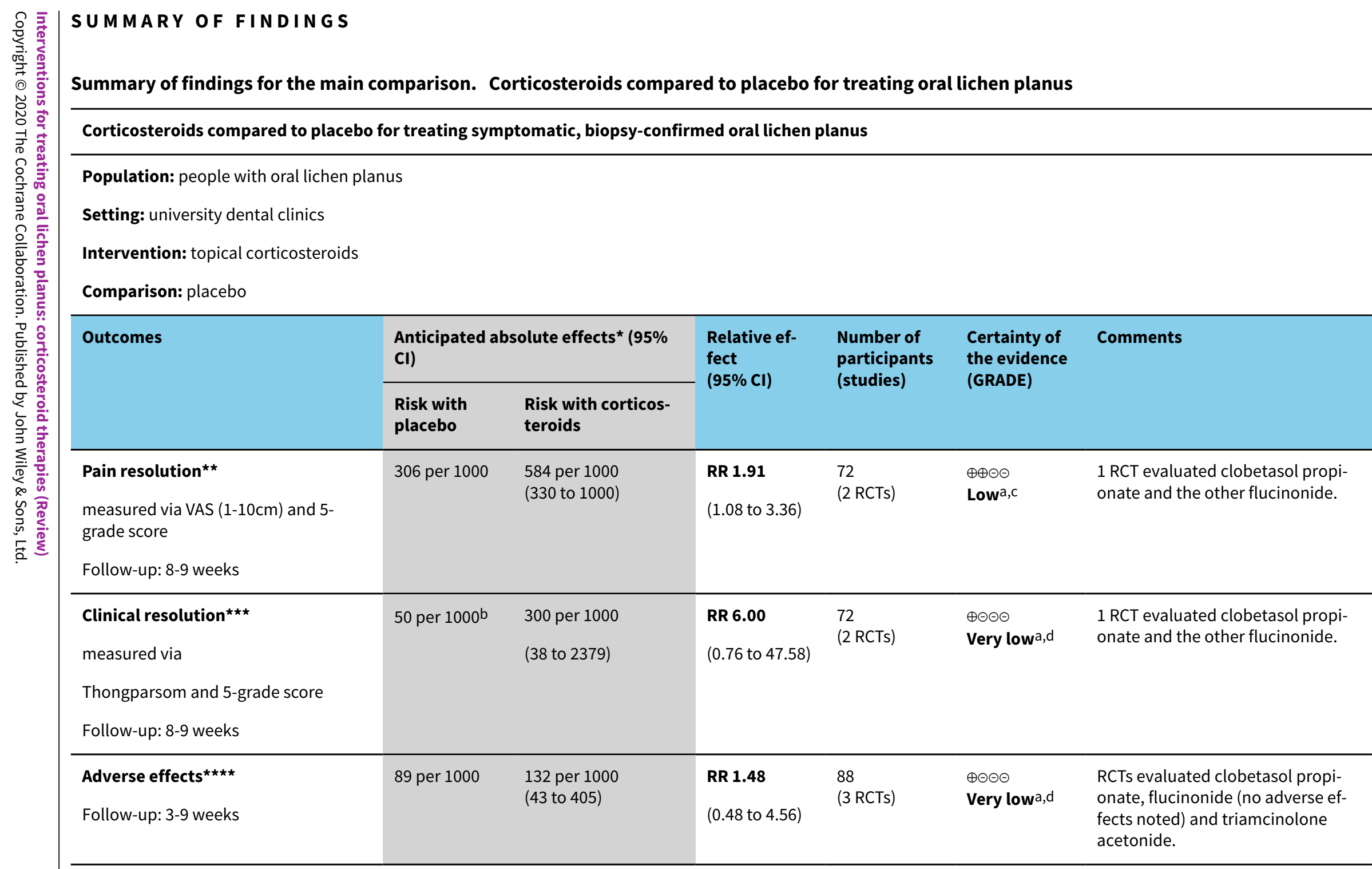

${ }^{\star}$ The risk in the intervention group (and its $95 \%$ confidence interval) is based on the assumed risk in the comparison group and the relative effect of the intervention (and its $95 \% \mathrm{Cl})$.

** Subjective assessment by participants at the end of treatment

${ }^{\star \star \star}$ Assessment by clinicians at the end of treatment 


\section{GRADE Working Group grades of evidence}

High certainty: we are very confident that the true effect lies close to that of the estimate of the effect.

Moderate certainty: we are moderately confident in the effect estimate: the true effect is likely to be close to the estimate of the effect, but there is a possibility that it is substantially different.

Low certainty: our confidence in the effect estimate is limited: the true effect may be substantially different from the estimate of the effect.

Very low certainty: we have very little confidence in the effect estimate: the true effect is likely to be substantially different from the estimate of effect.

a Downgraded one level due to risk of bias (one study judged at unclear risk).

bThere was zero risk in control group so we assumed a rate of $5 \%$.

cDowngraded one level due to imprecision (few participants and large $\mathrm{Cl}$ ).

dDowngraded two levels due to serious imprecision (few participants and large $\mathrm{Cl}$ that includes possibility of either corticosteroid or placebo being superior).

\section{Summary of findings 2 . Corticosteroids versus calcineurin inhibitors for treating oral lichen planus}

\section{Corticosteroids compared to calcineurin inhibitors for treating symptomatic, biopsy-confirmed oral lichen planus}

Population: people with oral lichen planus

Setting: university dental clinics

Intervention: topical corticosteroids

Comparison: topical calcineurin inhibitors

\begin{tabular}{|c|c|c|c|c|c|c|c|}
\hline \multirow[t]{2}{*}{ Outcomes } & \multirow{2}{*}{$\begin{array}{l}\text { Treatment compari- } \\
\text { son }\end{array}$} & \multicolumn{2}{|c|}{ Anticipated absolute effects ${ }^{\star}(95 \% \mathrm{Cl})$} & \multirow{2}{*}{$\begin{array}{l}\text { Relative effect } \\
(95 \% \mathrm{CI})\end{array}$} & \multirow{2}{*}{$\begin{array}{l}\text { № of partic- } \\
\text { ipants } \\
\text { (studies) }\end{array}$} & \multirow{2}{*}{$\begin{array}{l}\text { Certainty of } \\
\text { the evidence } \\
\text { (GRADE) }\end{array}$} & \multirow[t]{2}{*}{ Comments } \\
\hline & & $\begin{array}{l}\text { Risk with cal- } \\
\text { cineurin in- } \\
\text { hibitors }\end{array}$ & $\begin{array}{l}\text { Risk with corticos- } \\
\text { teroids }\end{array}$ & & & & \\
\hline $\begin{array}{l}\text { Pain resolution }{ }^{\star \star} \\
\text { measured via VAS and }\end{array}$ & $\begin{array}{l}\text { clobetasol vs ci- } \\
\text { closporin }\end{array}$ & 200 per 1000 & $\begin{array}{l}422 \text { per } 1000 \\
(152 \text { to } 1000)\end{array}$ & $\begin{array}{l}\text { RR } 2.11 \\
(0.76 \text { to } 5.86)\end{array}$ & $\begin{array}{l}39 \\
(1 \mathrm{RCT})\end{array}$ & $\begin{array}{l}\oplus \odot \odot \ominus \\
\text { Very low } a\end{array}$ & - \\
\hline Follow-up: 3-8 weeks & $\begin{array}{l}\text { clobetasol vs } \\
\text { tacrolimus }\end{array}$ & 440 per 1000 & $\begin{array}{l}198 \text { per } 1000 \\
\text { (106 to } 387)\end{array}$ & $\begin{array}{l}\mathbf{R R} \mathbf{0 . 4 5} \\
(0.24 \text { to } 0.88)\end{array}$ & $\begin{array}{l}100 \\
(2 \mathrm{RCTs})\end{array}$ & $\begin{array}{l}\oplus \odot \odot \ominus \\
\text { Very low } b\end{array}$ & - \\
\hline
\end{tabular}




\begin{tabular}{|c|c|c|c|c|c|c|c|}
\hline & $\begin{array}{l}\text { triamcinolone vs } \\
\text { tacrolimus }\end{array}$ & - & - & - & - & - & $\begin{array}{l}\text { No data for } \\
\text { this out- } \\
\text { come }\end{array}$ \\
\hline \multirow{3}{*}{$\begin{array}{l}\text { Clinical resolution }{ }^{\star \star \star} \\
\text { measured via Thong- } \\
\text { prasom and 4-grade } \\
\text { scale } \\
\text { Follow-up: 3-8 weeks }\end{array}$} & $\begin{array}{l}\text { clobestol vs ci- } \\
\text { closporin }\end{array}$ & 150 per 1000 & $\begin{array}{l}474 \text { per } 1000 \\
(150 \text { to } 1000)\end{array}$ & $\begin{array}{l}\text { RR } 3.16 \\
\text { (1.00 to } 9.93)\end{array}$ & $\begin{array}{l}39 \\
(1 \mathrm{RCT})\end{array}$ & $\begin{array}{l}\oplus \ominus \ominus \ominus \\
\text { Very lowc }\end{array}$ & - \\
\hline & $\begin{array}{l}\text { clobetasol vs } \\
\text { tacrolimus }\end{array}$ & 654 per 1000 & $\begin{array}{l}399 \text { per } 1000 \\
(248 \text { to } 647)\end{array}$ & $\begin{array}{l}\text { RR } 0.61 \\
(0.38 \text { to } 0.99)\end{array}$ & $\begin{array}{l}52 \\
\text { (2 RCTs) }\end{array}$ & $\begin{array}{l}\oplus \ominus \odot \ominus \\
\text { Very low }\end{array}$ & - \\
\hline & $\begin{array}{l}\text { triamcinolone vs } \\
\text { tacrolimus }\end{array}$ & 467 per 1000 & $\begin{array}{l}401 \text { per } 1000 \\
(257 \text { to } 630)\end{array}$ & $\begin{array}{l}\text { RR } 0.86 \\
(0.55 \text { to } 1.35)\end{array}$ & $\begin{array}{l}60 \\
\text { (2 RCTs) }\end{array}$ & $\begin{array}{l}\oplus \ominus \ominus \ominus \\
\text { Very lowe }\end{array}$ & - \\
\hline \multirow[t]{3}{*}{$\begin{array}{l}\text { Adverse effects } \\
\text { Follow-up: } 3-8 \text { weeks }\end{array}$} & $\begin{array}{l}\text { clobetasol vs ci- } \\
\text { closporin }\end{array}$ & 50 per 1000 & $\begin{array}{l}316 \text { per } 1000 \\
(42 \text { to } 1000)\end{array}$ & $\begin{array}{l}\text { RR } 6.32 \\
(0.84 \text { to } 47.69)\end{array}$ & $\begin{array}{l}39 \\
(1 \mathrm{RCT})\end{array}$ & $\begin{array}{l}\oplus \odot \odot \ominus \\
\text { Very low } a\end{array}$ & - \\
\hline & $\begin{array}{l}\text { clobetasol vs } \\
\text { tacrolimus }\end{array}$ & 180 per 1000 & $\begin{array}{l}9 \text { per } 1000 \\
(0 \text { to } 149)\end{array}$ & $\begin{array}{l}\text { RR } 0.05 \\
(0.00 \text { to } 0.83)\end{array}$ & $\begin{array}{l}100 \\
\text { (2 RCTs) }\end{array}$ & $\begin{array}{l}\oplus \ominus \odot \odot \\
\text { Very low }\end{array}$ & - \\
\hline & $\begin{array}{l}\text { triamcinolone vs } \\
\text { tacrolimus }\end{array}$ & 516 per 1000 & $\begin{array}{l}243 \text { per } 1000 \\
\text { (114 to } 511)\end{array}$ & $\begin{array}{l}\text { RR } \mathbf{0 . 4 7} \\
(0.22 \text { to } 0.99)\end{array}$ & $\begin{array}{l}58 \\
\text { (2 RCTs) }\end{array}$ & $\begin{array}{l}\oplus \oplus \ominus \ominus \\
\text { Lowg }\end{array}$ & - \\
\hline
\end{tabular}

${ }^{\star}$ The risk in the intervention group (and its $95 \%$ confidence interval) is based on the assumed risk in the comparison group and the relative effect of the intervention (and its $95 \% \mathrm{Cl}$ ).

** Subjective assessment by participants at the end of treatment

${ }^{* * *}$ Assessment by clinicians at the end of treatment

**** Reported by participants throughout the duration of the study

CI: confidence interval; RCT: randomised controlled trial; RR: risk ratio; VAS: visual analogue scale.

\section{GRADE Working Group grades of evidence}

High certainty: we are very confident that the true effect lies close to that of the estimate of the effect.

Moderate certainty: we are moderately confident in the effect estimate: the true effect is likely to be close to the estimate of the effect, but there is a possibility that it is substantially different.

Low certainty: our confidence in the effect estimate is limited: the true effect may be substantially different from the estimate of the effect.

Very low certainty: we have very little confidence in the effect estimate: the true effect is likely to be substantially different from the estimate of effect. 
${ }^{a}$ Downgraded three levels as very small single study at unclear risk of bias, with large $\mathrm{Cl}$ that includes the possibility of either intervention being superior.

bDowngraded three levels as small number of participants, with one study at unclear risk of bias, and very high heterogeneity.

'Downgraded three levels as very small single study at unclear risk of bias, with large $\mathrm{Cl}$ that included the possibility that there is no difference between the interventions.

dDowngraded three levels as small number of participants in two studies at unclear risk of bias, and very high heterogeneity.

eDowngraded three levels as small number of participants in two studies at unclear risk of bias, and very high heterogeneity, with large $\mathrm{Cl}$ that included the possibility of either intervention being superior.

fDowngraded three levels as small number of participants and events, both studies at unclear risk of bias and large $\mathrm{Cl}$ including no difference between the interventions.

gDowngraded two levels as small number of participants and wide $\mathrm{Cl}$, and one study at unclear risk of bias. 


\section{B A C K G R O U N D}

\section{Description of the condition}

Oral lichen planus (OLP) is a chronic disorder of the oral cavity that rarely undergoes spontaneous remission. Despite the lack of good epidemiological data, OLP is thought to be relatively common, affecting approximately $1 \%$ to $2 \%$ of the population, mainly middle-aged adults (Alrashdan 2016). Women are slightly more likely than men to have this condition. The most commonly affected sites are the buccal mucosa bilaterally, the borders and dorsum of the tongue, and the gingiva. The palate (either hard or soft), the lips and the floor of the mouth are rarely involved.

Typical OLP clinical features are represented by bilaterally located white papules that enlarge and coalesce to form reticulations, the so-called Wickham's striae (Carrozzo 1999), which are rarely symptomatic. In contrast, erythematous and erosive or ulcerative lesions can cause varying degrees of discomfort. Symptomatic OLP is relatively frequent and can significantly impair quality of life (López-Jornet 2010; Tadakamadla 2015).

Moreover, the disease has a fluctuating course with apparent spontaneous exacerbations and improvements in disease activity within an individual patient.

Current evidence suggests that people with OLP have an increased risk of developing oral squamous cell carcinoma (SCC) (Eisen 2002; Gonzalez-Moles 2008), and this has to be considered when planning therapeutic interventions (Aghbari 2017). However, this topic will not be addressed in this review.

Clinical appearance alone, particularly when showing the 'classic' reticular form, may sometimes allow a definitive diagnosis. However, given the chronic course of the disease, the sometimes pleomorphic clinical manifestations, and the common long-term treatment and monitoring of people with OLP, biopsy is a prudent - yet still controversial - clinical practice. Inappropriate diagnosis is a notable cause of therapy failure, so histopathological confirmation of OLP is helpful before starting an active treatment. Histopathology can be subjective and non-specific (Van der Meij 2003), but it can be useful to exclude dysplasia and SCC. When exclusive gingival or predominantly erosive or ulcerative lesions are present, immunological tests are warranted to achieve a proper diagnosis.

OLP is probably a T cell-mediated immunological reaction to an induced antigenic change in the oral mucosa in predisposed people. An early event in OLP is the genetically driven enhanced production of Th1 cytokines, particularly tumour necrosis factoralpha (TNF- $\alpha$ ) and interferon-gamma (IFN- $\gamma$ ) (Carrozzo 2004). Studies of $\mathrm{T}$ cell receptor variable region genes have highlighted that OLP is likely to be the common outcome of a limited combination of extrinsic antigens, altered self-antigens or super antigens (Thomas 1997). In a minority of people, aetiological factors can be identified and they are usually drugs, dental materials and infectious agents, especially hepatitis $C$ virus infection (Lodi 2005a; Lodi 2010).

\section{Description of the intervention}

Various treatment regimens have been employed to treat ulcerative lesions, and, more importantly, to reduce the associated pain, though a definitive cure for OLP has not yet been achieved (Lodi 2005b). The primary goal of treatment of symptomatic OLP is the reduction and preferably elimination of pain associated with the lesions.

\section{How the intervention might work}

Because OLP is considered a T cell-mediated disease associated with a Th1 imbalance of cytokine production, most of the therapeutic interventions have aimed to target the inflammatory pathway underlying OLP. In particular, local suppression of T cells and $a$ reduction in the release of cytokines such as TNF- $\alpha$ and IFN- $\gamma$ are highly regarded in OLP management. As a result, the mainstay medications in OLP management are anti-inflammatory drugs. The most commonly used anti-inflammatory medication is glucocorticosteroids, commonly called corticosteroids. Around 1950, topical glucocorticosteroids (TGCs) were employed to treat skin inflammatory disease; the use of TGCs for mouth diseases, including OLP, started around a decade later (Zegarelli 1960). TGCs have a multiplicity of actions: anti-inflammatory, immunomodulatory, vasoconstrictor, and they can inhibit the activity of several cytokines following inactivation of specific transcription factors such as activator protein 1 (AP-1) and nuclear factor kappa B (NFKB) (Ahluwalia 1998). Specifically, the analgesic effect of corticosteroids is likely related to their effect on the inflammatory pathway underlying OLP and its beneficial effect on mucosal healing and integrity.

\section{Why it is important to do this review}

Symptomatic OLP is a relatively common, painful oral disorder that can significantly impair quality of life (Tadakamadla 2015). Because of its chronic nature and lack of an apparent cause, a definitive cure is very difficult to achieve. Current treatments aim to reduce pain and to heal erosive and ulcerative lesions. Most published reviews on the topic suggest the use of topical drugs, mainly TGCs (Al-Hashimi 2007; Carrozzo 1999; Carrozzo 2009; Cribier 1998; Eisen 2005; Lodi 2005b); however, the previous version of this Cochrane Review provided only weak evidence for the superiority of any interventions over placebo for palliation of symptomatic OLP (Other published versions of this review). As we were aware of an increasing number of randomised controlled trials (RCTs) evaluating corticosteroids, we updated the review, focusing on these interventions. A further review on non-corticosteroids is also being produced.

\section{O B JECT IVES}

To assess the effects and safety of corticosteroids, in any formulation, for treating people with symptoms of oral lichen planus.

\section{METHODS}

\section{Criteria for considering studies for this review}

\section{Types of studies}

We included RCTs. We excluded quasi-randomised trials (where treatment assignment was by alternating sequence, date of birth, registration number or some other such non-random method).

\section{Types of participants}

We included participants satisfying the following criteria. 
- Having a clinical and histological diagnosis of OLP.

- Having painful symptoms associated with OLP.

- Not concurrently receiving any other treatment for OLP or treatment likely to modify their OLP (e.g. systemic steroids, antifungals or immunosuppressants).

For people being treated for both skin and OLP, we extracted only the OLP data; if this was not possible, we excluded the study.

\section{Types of interventions}

Any local or systemic corticosteroid treatment compared with a placebo, a calcineurin inhibitor, another corticosteroid, any other local or systemic treatment, or the same corticosteroid plus an adjunctive treatment.

\section{Types of outcome measures}

\section{Primary outcomes}

- Pain (score and resolution) as assessed by participants (measured at the end of the treatment course).

\section{Secondary outcomes}

- Clinical response (score and resolution of the disease) in terms of changes in the extension and severity (degree of erosion, erythema and reticulation) as assessed by clinicians (measured at the end of the treatment course).

- Adverse effects, including clinical candidiasis or other toxic and side effects (measured at any time point).

\section{Search methods for identification of studies}

\section{Electronic searches}

Cochrane Oral Health's Information Specialist conducted systematic searches in the following databases. The search was inclusive of RCTs and controlled clinical trials, but the latter were filtered out during the selection process. There were no language, publication year or publication status restrictions.

- Cochrane Oral Health's Trials Register (searched 25 February 2019; Appendix 1).

- Cochrane Central Register of Controlled Trials (CENTRAL; 2019, Issue 1) in the Cochrane Library (searched 25 February 2019; Appendix 2).

- MEDLINE Ovid (1946 to 25 February 2019; Appendix 3).

- Embase Ovid (1980 to 25 February 2019; Appendix 4).

Subject strategies were modelled on the search strategy designed for MEDLINE Ovid. Where appropriate, they were combined with subject strategy adaptations of the highly sensitive search strategy designed by Cochrane for identifying RCTs and controlled clinical trials as described in Chapter 6 of the Cochrane Handbook for Systematic Reviews of Interventions (Lefebvre 2011).

\section{Searching other resources}

The following trial registries were searched for ongoing studies:

- US National Institutes of Health Ongoing Trials Register ClinicalTrials.gov (clinicaltrials.gov; searched 25 February 2019; Appendix 5);
- World Health Organization International Clinical Trials Registry Platform (apps.who.int/trialsearch; searched 25 February 2019; Appendix 6).

We also checked the reference lists of identified publications for relevant studies, and contacted authors to identify missing and unreported trials.

We checked that none of the included studies in this review were retracted due to error or fraud.

We did not perform a separate search for adverse effects of interventions used; we considered adverse effects described in included studies only.

\section{Data collection and analysis}

\section{Selection of studies}

Three review authors independently scanned titles and abstracts (when available) of all reports identified. The search was designed to be sensitive and include controlled clinical trials, these were filtered out early in the selection process if they were not randomised. For studies appearing to meet the inclusion criteria, or when there was insufficient information in the title and abstract to make a clear decision, we obtained the full reports and all review authors independently assessed them to establish if they met inclusion criteria. We resolved disagreements by discussion. We recorded studies that we rejected at this or subsequent stages in the Characteristics of excluded studies table, along with the reasons for exclusion.

\section{Data extraction and management}

At least two review authors extracted data from all studies meeting the inclusion criteria, using a specially designed form. We recorded the characteristics of the trial participants, interventions and outcomes in the Characteristics of included studies table. The studies measured the effects of treatment on pain and clinical presentation using scales and scoring systems, which were often significantly different and difficult to compare. In order to increase the amount of comparable data, we decided to record the number of participants who did not receive benefit in terms of symptoms (pain) and clinical signs.

\section{Assessment of risk of bias in included studies}

All review authors independently assessed the risk of bias of the included trials. All review authors independently assessed the full-text papers, unblinded, and resolved disagreements through discussion and consensus. We used the recommended tool for assessing risk of bias in studies included in Cochrane Reviews (Higgins 2011). It is a two-part tool, addressing seven specific domains as follows:

- random sequence generation (selection bias);

- allocation concealment (selection bias);

- blinding of participants and personnel (performance bias);

- blinding of outcome assessment (detection bias);

- incomplete outcome data (attrition bias);

- selective reporting (reporting bias);

- other bias. 
Each domain in the tool includes one or more specific entries in a 'Risk of bias' table. Within each entry, the first part of the tool describes what was reported to have happened in the study, in sufficient detail to support a judgement about the risk of bias. The second part of the tool assigns a judgement relating to the risk of bias for that entry. This is achieved by assigning a judgement of 'low', 'high' or 'unclear' risk of bias.

After taking into account the additional information provided by trial authors, we categorised trials as:

- overall low risk of bias if low risk of bias for all key domains;

- overall unclear risk of bias if unclear risk of bias for one or more key domains; or

- overall high risk of bias if high risk of bias for one or more key domains.

We completed a 'Risk of bias' table for each included study (see Characteristics of included studies table), and presented the results graphically by study and by domain across all studies.

\section{Measures of treatment effect}

For dichotomous outcomes, we expressed the estimates of effects of an intervention as risk ratios (RR) or odds ratios (OR) if paired, together with $95 \%$ confidence intervals $(\mathrm{Cls})$. For continuous outcomes, we used mean differences (MD) and standard deviation (SD) for each group in order to express the estimate of effect as MD with $95 \% \mathrm{Cl}$. If studies reported continuous outcomes on different scales, we planned to use standardised mean difference (SMD) to pool these data in meta-analyses. For paired data (split-mouth studies), we used the generic inverse variance method (Higgins 2011).

\section{Unit of analysis issues}

The statistical unit of analysis was the participant.

For studies with more than two control arms, we selected the one we considered most appropriate to compare.

We intended to analyse split-mouth and cross-over trials. Where the intraclass correlation was not provided for cross-over and splitmouth trials, we estimated this as 0.5 .

\section{Dealing with missing data}

We contacted trialists to ask them to supply missing information and to clarify points.

\section{Assessment of heterogeneity}

We assessed the significance of any discrepancies in the estimates of the treatment effects from the different trials by means of Cochrane's test for heterogeneity and the $\mathrm{I}^{2}$ statistic, which describes the percentage total variation across studies that is due to heterogeneity rather than chance. We considered heterogeneity to be statistically significant if the $P$ value was less than 0.1 . A rough guide to the interpretation of the $1^{2}$ statistic given in the Cochrane Handbook for Systematic Reviews of Interventions is: $0 \%$ to $40 \%$ might not be important, $30 \%$ to $60 \%$ may represent moderate heterogeneity, $50 \%$ to $90 \%$ may represent substantial heterogeneity and $75 \%$ to $100 \%$ is considerable heterogeneity (Higgins 2011).

\section{Assessment of reporting biases}

We attempted to minimise reporting biases by conducting a thorough search of multiple sources including trial registries, and efforts to identify unpublished trials and non-English language publications.

\section{Data synthesis}

Where studies comparing similar interventions reported the same outcome measures, we combined the data in meta-analyses. We combined RRs for dichotomous data, and MDs for continuous data, using fixed-effect models unless there were more than three studies being combined. We dichotomised four- or five-step rating scales as appropriate. If studies reported continuous outcomes on different scales, we planned to use SMD to pool these data in meta-analyses.

\section{Subgroup analysis and investigation of heterogeneity}

If there were sufficient studies, we planned to assess clinical heterogeneity by examining the characteristics of participants included in the studies.

\section{Sensitivity analysis}

If there were sufficient studies, we planned to undertake sensitivity analyses to examine the effect of the study risk of bias assessment on the overall estimates of effect.

\section{'Summary of findings' table}

We created 'Summary of findings' tables for the comparisons of treatments considered 'first choice' and routinely adopted in clinical practice, and presented summary information for primary outcomes, in particular pain resolution, clinical resolution and adverse effects. At least two review authors (of GL, MM, MC, VM) independently assessed the certainty of evidence using GRADE criteria (Schünemann 2017), which considers a body of RCT evidence to provide high-certainty evidence unless 'downgraded' by one, two or three levels (to moderate, low or very low certainty, respectively) on the basis of problems in study design, imprecision, inconsistency, indirectness or publication bias.

\section{RES U L T S}

\section{Description of studies}

See Characteristics of included studies table.

\section{Results of the search}

We identified 1030 records and rejected 943 on the basis of title or abstract. We considered 87 articles in full text and excluded 36 of these (we also excluded 11 studies that had been included in the previous version of the review as these will be part of our sister review on non-corticosteroids). Two studies are awaiting classification and we found 12 ongoing studies. Therefore, we included 37 articles (35 RCTs) in this review. See Figure 1. 
Figure 1. Study flow diagram of searches for this update.

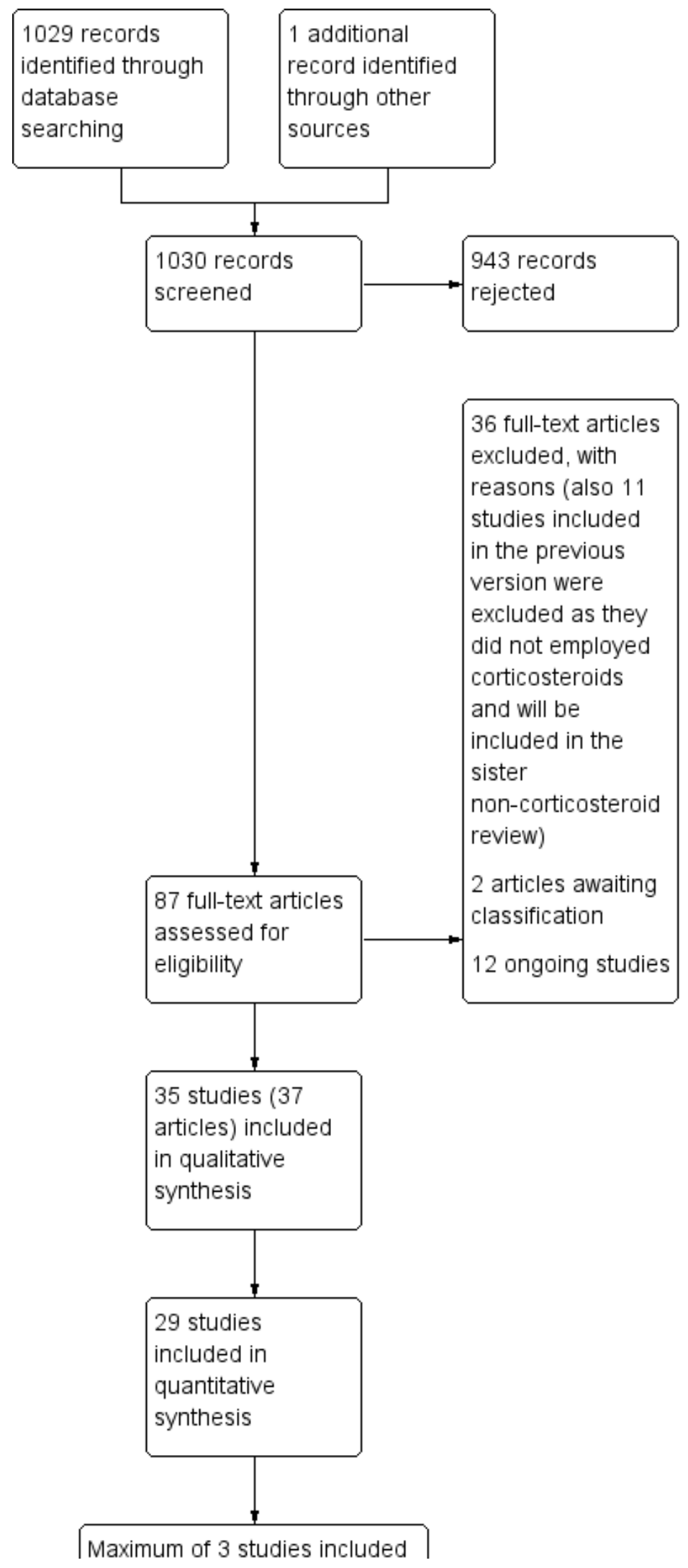


Figure 1. (Continued)

$$
\begin{aligned}
& \text { Maximum of } 3 \text { studies included } \\
& \text { in any individual meta-analysis }
\end{aligned}
$$

\section{Included studies}

For a summary of the characteristics of each of the included studies, see the Characteristics of included studies tables.

\section{Characteristics of the trials}

\section{Design}

Twenty-nine trials used a two-arm parallel design; four used a three-arm parallel design (Hesen 2017; Siponen 2017; Sivaraman 2016; Thomas 2017), though we used only two arms from Hesen 2017 and Thomas 2017; one used a two-arm cross-over design (Hegarty 2002); and one used a split-mouth design (Amanat 2014).

The total number of participants included in the trials was 1474 , with the number per study ranging from 20 to 139 .

\section{Setting}

Seven studies were conducted in Iran (Amanat 2014; Amirchaghmaghi 2016; Bakhtiari 2017; Ghabanchi 2009; Gorouhi 2007; Kia 2015; Pakfetrat 2015), six in Italy (Arduino 2018; Campisi 2004; Carbone 2009; Conrotto 2006; Corrocher 2008; Lodi 2007), five in China (Fu 2012; Liu 2013; Wei 2003; Xiong 2009; Xu 2002), four in India (Arunkumar 2015; Malhotra 2008; Sivaraman 2016; Thomas 2017), four in Egypt (Ezzatt 2019; Hashem 2019; Hesen 2017; Mostafa 2017), two in the Netherlands (Laeijendecker 2006; Voute 1993), one in the US (Chainani-Wu 2007), one in Sweden (Rodstrom 1994), one in the UK (Hegarty 2002), one in Brazil (Dillenburg 2014), one in Sri Lanka (Hettiarachchi 2017), one in Finland (Siponen 2017), and one was an Asian multicentre study (Singapore, South Korea, India, Thailand) (Yoke 2006). All the studies were conducted in university clinics or hospitals.

\section{Funding}

Companies provided drugs to four trials (Conrotto 2006; Gorouhi 2007; Voute 1993; Yoke 2006); one trial received support for the multicentric co-ordination and study drug from the sponsor (Yoke 2006); two received support from the principal investigator (Arduino 2018; Ezzatt 2019); and 10 received support from institutional funding bodies (Amanat 2014; Amirchaghmaghi 2016; Chainani-Wu 2007; Dillenburg 2014; Ghabanchi 2009; Hettiarachchi 2017; Lodi 2007; Pakfetrat 2015; Siponen 2017; Xiong 2009).

\section{Characteristics of the interventions}

See Table 1.

Three trials compared a corticosteroid drug (flucinonide, triamcinolone acetonide and clobetasol propionate in different adhesive bases) with placebo (Arduino 2018; Siponen 2017; Voute 1993).

Eleven studies compared a corticosteroid with a calcineurin inhibitor; they compared: clobetasol propionate with ciclosporin (Conrotto 2006); clobetasol propionate with tacrolimus (Corrocher 2008; Hettiarachchi 2017; Sivaraman 2016); triamcinolone acetonide with pimecrolimus (Arunkumar 2015; Gorouhi 2007; Pakfetrat 2015); triamcinolone acetonide with tacrolimus (Laeijendecker 2006; Siponen 2017; Sivaraman 2016); and triamcinolone acetonide with ciclosporin (Yoke 2006); and betamethasone gel with pimecrolimus gel (Ezzatt 2019).

Eight studies compared two corticosteroids or the same corticosteroid in different modalities: one compared two different formulations of clobetasol propionate (Campisi 2004); one compared two ointments with different concentrations (Carbone 2009); two compared different preparations of betamethasone with triamcinolone acetonide (Liu 2013; Malhotra 2008); two compared clobetasol propionate with triamcinolone acetonide (Rodstrom 1994; Sivaraman 2016); one compared prednisolone with triamcinolone acetonide (Ghabanchi 2009); one compared fluticasone propionate with betamethasone sodium phosphate (Hegarty 2002).

Nine trials compared corticosteroids with other treatments; two compared triamcinolone acetonide with curcumin (Kia 2015; Thomas 2017), two compared topical corticosteroids with photodynamic therapy (Bakhtiari 2017; Mostafa 2017); one compared triamcinolone acetonide with cryotherapy (Amanat 2014), one compared clobetasol propionate with laser diode (Dillenburg 2014), one compared triamcinolone acetonide with bacillus Calmette-Guerin polysaccharide nucleic acid (Xiong 2009), one compared dexamethasone with amlexanox (Fu 2012), and one compared triamcinolone acetonide gel with hyaluronic acid gel (Hashem 2019).

Five trials tested a treatment adjunctive to the corticosteroid (i.e. both groups received the same corticosteroid) (Amirchaghmaghi 2016; Chainani-Wu 2007; Hesen 2017; Lodi 2007; Wei 2003). Two studies tested antimycotic drugs as adjunctive treatment (Lodi 2007; Wei 2003), and two tested curcumin (Chainani-Wu 2007; Dillenburg 2014). One study compared three-stage treatment integrating Western and Chinese medicine, with a two-stage Western medicine approach (Xu 2002).

Due to the limited availability of commercial preparations to be used in the oral mucosa, most of the studies employed ad hoc or galenical preparations.

The treatment courses varied from one week to six months, with the majority lasting one to two months.

\section{Characteristics of the outcomes}

There were three main outcomes reported in the trials included in this review: pain (score and resolution), clinical response (score and resolution) and adverse effects of treatment. The outcomes were measured between one week and six months.

\section{Pain}

Twenty-seven studies used visual analogue scales (VAS) to measure pain. This is a validated tool used by participants to assess their 
own pain on a $0-\mathrm{mm}$ to $100-\mathrm{mm}$ or $0-\mathrm{cm}$ to $10-\mathrm{cm}$ scale, where the lower the value, the lower the pain. Three studies adopted rating scales (Corrocher 2008; Thomas 2017; Voute 1993). We dichotomised Likert scales into complete resolution versus partial or no resolution. Five studies did not measure pain (Ghabanchi 2009; Laeijendecker 2006; Sivaraman 2016; Wei 2003; Xu 2002).

\section{Conrotto?}

\section{Clinical response}

All studies measured clinical response to treatment. Four measured the size of the affected area (Fu 2012; Liu 2013; Lodi 2007; Xiong 2009). Seventeen studies used the Thongprasom clinical score or a modification of it (Amanat 2014; Amirchaghmaghi 2016; Arduino 2018; Arunkumar 2015; Bakhtiari 2017; Campisi 2004; Carbone 2009; Conrotto 2006; Dillenburg 2014; Gorouhi 2007; Hegarty 2002; Hesen 2017; Hettiarachchi 2017; Kia 2015; Mostafa 2017; Pakfetrat 2015; Yoke 2006). Three studies used the modified oral mucositis index (Chainani-Wu 2007; Hashem 2019; Thomas 2017). Eight studies used a four- or five-grade rating scale (Corrocher 2008; Ezzatt 2019; Ghabanchi 2009; Laeijendecker 2006; Rodstrom 1994; Voute 1993; Wei 2003; Xu 2002). Malhotra 2008 used a semiquantitative scoring system and Siponen 2017 measured changes in clinical scores (modified from Setterfield) from baseline to week three. Sivaraman 2016 provided a dichotomous outcome only: complete resolution.

\section{Adverse effects}

Twenty-one studies reported general adverse effects of treatment (Amirchaghmaghi 2016; Arduino 2018; Campisi 2004; Carbone 2009; Chainani-Wu 2007; Conrotto 2006; Corrocher 2008; Dillenburg 2014; Ezzatt 2019; Fu 2012; Ghabanchi 2009; Gorouhi 2007; Hegarty 2002; Hettiarachchi 2017; Laeijendecker 2006; Liu 2013; Lodi 2007; Malhotra 2008; Rodstrom 1994; Siponen 2017; Xiong 2009). The remaining studies either did not consider adverse effects at all, or did not report data in an usable form.

\section{Other outcomes not relevant for this review}

Other outcomes reported in the studies but not relevant for this review were relapses (Arduino 2018; Carbone 2009; Dillenburg 2014; Liu 2013), quality of life (Gorouhi 2007; Hegarty 2002), anxiety and function (Dillenburg 2014), and cost (Conrotto 2006).

\section{Excluded studies}

We divided the content of our previous reviews (Chan 1999; Thongprasom 2011) into two reviews, this one focusing on corticosteroid treatment, and another, currently in progress, on non-corticosteroid treatments. Therefore, we removed from this update 11 trials of non-corticosteroid treatments that were included in the previous version of this review (Agha-Hosseini 2010; Choonhakarn 2008; Eisen 1990; Gaeta 1994; Lundquist 1995; Mousavi 2009; Nolan 2009; Passeron 2007; Salazar-Sánchez 2010; Swift 2005; Volz 2008). These are listed in the Characteristics of excluded studies table. There we also listed the 47 articles that seemed initially to be relevant but we found did not fulfil inclusion criteria when we studied the full texts.

\section{Studies awaiting classification}

Two studies await classification (Fricain 2014; Qu 2016) (see Characteristics of studies awaiting classification tables).

\section{Ongoing studies}

We found 12 ongoing studies (2017-002193-40; ChiCTR1800016507; CTRI/2018/03/012661; CTRI/2018/08/015185; CTRI/2018/08/015563; Ferri 2018; IRCT20171017036835N2; IRCT20181226042133N1; NCT03386643; NCT03592342; NCT03738176; NCT03793634) (see Characteristics of ongoing studies). Two trials are comparing a corticosteroid drug (clobetasol propionate patches) with placebo; eight trials are comparing a corticosteroid drug with another treatment (systemic and topic curcumin; natural products with Vitamin E; vitamin $\mathrm{C}$ and propolis; neem leaves mouthwash; photobiomodulation; vitamin D capsules; probiotic treatment; topical sesame oil and topical chamomile). Finally, two trials are comparing two different corticosteroids (betamethasone versus dexamethasone mouth rinse; mucoadhesive nano-triamcinolone gel versus conventional triamcinolone gel).

\section{Risk of bias in included studies}

\section{Allocation}

We considered the method of randomisation adequate in both its components (sequence generation and allocation concealment) in 14 trials (Amirchaghmaghi 2016; Arduino 2018; Carbone 2009; Conrotto 2006; Ezzatt 2019; Gorouhi 2007; Hegarty 2002; Hesen 2017; Hettiarachchi 2017; Lodi 2007; Malhotra 2008; Pakfetrat 2015; Siponen 2017; Yoke 2006); in nine trials, sequence generation was adequate, but allocation concealment unclear (ChainaniWu 2007; Corrocher 2008; Dillenburg 2014; Fu 2012; Kia 2015; Laeijendecker 2006; Liu 2013; Sivaraman 2016; Xiong 2009), and in the remaining 12 trials, sequence generation and allocation concealment were both unclear (Amanat 2014; Arunkumar 2015; Bakhtiari 2017; Campisi 2004; Ghabanchi 2009; Hashem 2019; Mostafa 2017; Rodstrom 1994; Thomas 2017; Voute 1993; Wei 2003; Xu 2002).

\section{Blinding \\ Performance bias}

We judged 12 trials at low risk of performance bias as both participants and personnel were blinded (Amirchaghmaghi 2016; Arduino 2018; Carbone 2009; Chainani-Wu 2007; Corrocher 2008; Ezzatt 2019; Hettiarachchi 2017; Lodi 2007; Rodstrom 1994; Siponen 2017; Voute 1993; Wei 2003).

We judged 14 trials at high risk of performance bias (Amanat 2014; Bakhtiari 2017; Campisi 2004; Dillenburg 2014; Ghabanchi 2009; Gorouhi 2007; Hegarty 2002; Liu 2013; Malhotra 2008; Mostafa 2017; Pakfetrat 2015; Thomas 2017; Xiong 2009; Xu 2002), and nine studies as unclear (Arunkumar 2015; Conrotto 2006; Fu 2012; Hashem 2019; Hesen 2017; Kia 2015; Laeijendecker 2006; Sivaraman 2016; Yoke 2006).

\section{Detection bias}

Fourteen studies reported that outcome assessment was blind so we judged these at low risk of detection bias (Amirchaghmaghi 2016; Arduino 2018; Carbone 2009; Chainani-Wu 2007; Conrotto 2006; Corrocher 2008; Ezzatt 2019; Hettiarachchi 2017; Kia 2015; Lodi 2007; Rodstrom 1994; Siponen 2017; Voute 1993; Wei 2003).

Fifteen studies were at high risk of detection bias (Amanat 2014; Bakhtiari 2017; Campisi 2004; Dillenburg 2014; Ghabanchi 2009; Gorouhi 2007; Hegarty 2002; Hesen 2017; Liu 2013; Malhotra 2008; 
Mostafa 2017; Pakfetrat 2015; Thomas 2017; Xiong 2009; Xu 2002), and six studies as unclear (Arunkumar 2015; Fu 2012; Hashem 2019; Laeijendecker 2006; Sivaraman 2016; Yoke 2006).

\section{Incomplete outcome data}

We judged 31 trials at low risk of attrition bias since all enrolled participants completed the study, or the number of participants lost was not likely to have a clinically relevant impact on the intervention effect estimate, or intention-to-treat (ITT) analysis was performed (Amirchaghmaghi 2016; Arduino 2018; Arunkumar 2015; Bakhtiari 2017; Campisi 2004; Carbone 2009; Chainani-Wu 2007; Conrotto 2006; Corrocher 2008; Ezzatt 2019; Fu 2012; Ghabanchi 2009; Gorouhi 2007; Hashem 2019; Hegarty 2002; Hesen 2017; Hettiarachchi 2017; Kia 2015; Laeijendecker 2006; Liu 2013; Lodi 2007; Malhotra 2008; Mostafa 2017; Rodstrom 1994; Siponen 2017; Sivaraman 2016; Thomas 2017; Voute 1993; Wei 2003; Xu 2002; Yoke 2006).

We judged four trials at high risk of attrition bias since the rate of dropouts was higher than 20\% (Amanat 2014; Dillenburg 2014; Pakfetrat 2015), or was very imbalanced between groups (Xiong 2009).

\section{Selective reporting}

We judged 26 trials at low risk of bias since all planned outcomes were reported (Amanat 2014; Amirchaghmaghi 2016; Arduino 2018; Arunkumar 2015; Campisi 2004; Carbone 2009; Conrotto 2006; Corrocher 2008; Ezzatt 2019; Fu 2012; Gorouhi 2007; Hashem 2019; Hegarty 2002; Hettiarachchi 2017; Kia 2015; Laeijendecker 2006; Liu 2013; Lodi 2007; Mostafa 2017; Pakfetrat 2015; Siponen 2017 ;

\section{Figure 2. Risk of bias graph: review authors' judgements about each risk of bias item presented as percentages}

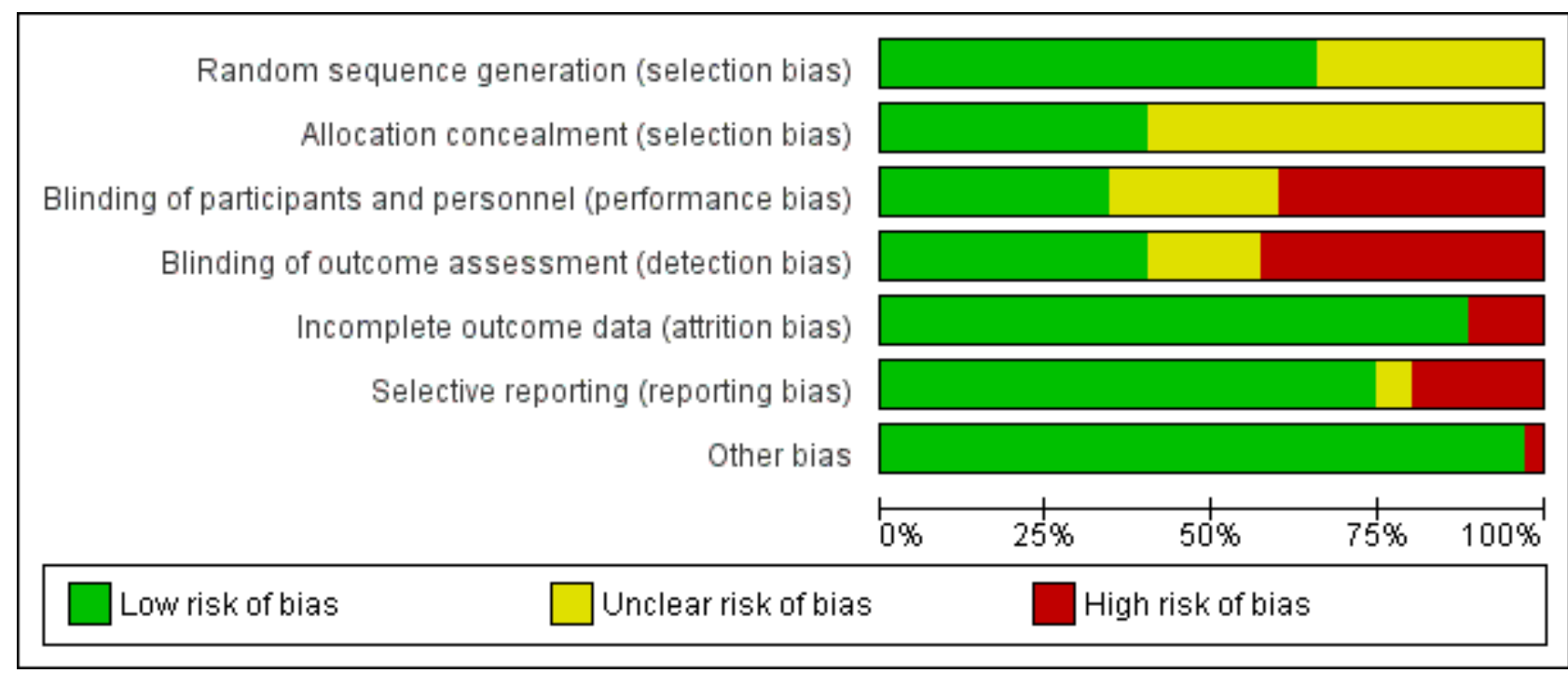

Interventions for treating oral lichen planus: corticosteroid therapies (Review)

Copyright ( 2020 The Cochrane Collaboration. Published by John Wiley \& Sons, Ltd. Xu 2002; Yoke 2006).

Seven studies reported one or more outcomes of interest incompletely or in a way that did not allow quantitative analysis, thus we judged them at high risk of bias (Bakhtiari 2017; ChainaniWu 2007; Dillenburg 2014; Ghabanchi 2009; Hesen 2017; Malhotra 2008; Rodstrom 1994).

We assessed the remaining two trials at unclear risk of selective outcome reporting bias as there was insufficient information to make a judgement (Wei 2003; Xu 2002).

\section{Other potential sources of bias}

In one study, the two groups had a statistically significant difference in clinical score at baseline (Malhotra 2008).

\section{Overall risk of bias}

Seven studies were at overall low risk of bias (Amirchaghmaghi 2016; Arduino 2018; Carbone 2009; Ezzatt 2019; Hettiarachchi 2017; Lodi 2007; Siponen 2017); 11 were at unclear risk of bias overall (Arunkumar 2015; Conrotto 2006; Corrocher 2008; Fu 2012; Hashem 2019; Kia 2015; Laeijendecker 2006; Sivaraman 2016; Voute 1993; Wei 2003; Yoke 2006); and the remaining 17 studies were at high risk of bias (because of no blinding, incomplete outcome data, selective reporting or baseline imbalance) (Amanat 2014; Bakhtiari 2017; Campisi 2004; Chainani-Wu 2007; Dillenburg 2014; Ghabanchi 2009; Gorouhi 2007; Hegarty 2002; Hesen 2017; Liu 2013; Malhotra 2008; Mostafa 2017; Pakfetrat 2015; Rodstrom 1994; Thomas 2017; Xiong 2009; Xu 2002). Risk of bias assessments are summarised in Figure 2 and Figure 3.

\section{across all included studies.}


Figure 3. Risk of bias summary: review authors' judgements about each risk of bias item for each included study.

\begin{tabular}{|c|c|c|c|c|c|c|c|}
\hline & 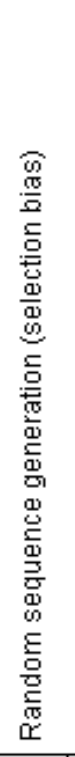 & 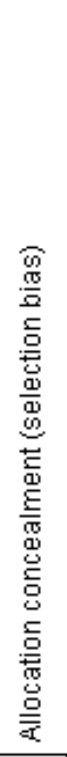 & 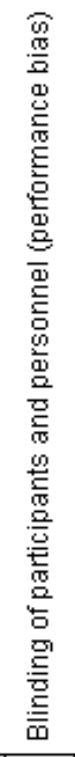 & 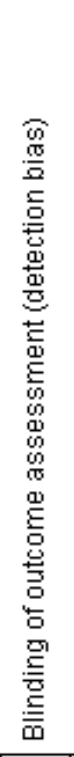 & 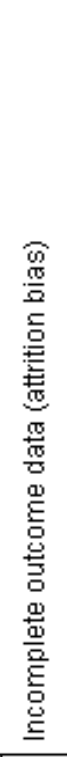 & 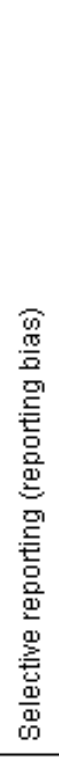 & 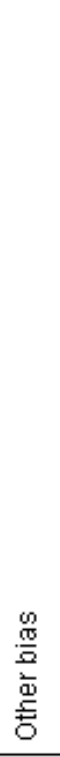 \\
\hline Amanat 2014 & $?$ & $?$ & $\odot$ & $\odot$ & $\odot$ & $\oplus$ & $\odot$ \\
\hline Amirchaghmaghi 2016 & + & $\odot$ & $\odot$ & + & + & $\odot$ & $\odot$ \\
\hline Arduino 2018 & + & $\odot$ & + & + & $\odot$ & + & $\odot$ \\
\hline Arunkumar 2015 & $?$ & $?$ & $?$ & $?$ & $\odot$ & 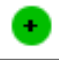 & $\odot$ \\
\hline Bakhtiari 2017 & $?$ & $?$ & - & - & + & $\odot$ & + \\
\hline Campisi 2004 & $?$ & $?$ & $\theta$ & $\theta$ & + & + & + \\
\hline Carbone 2009 & + & $\odot$ & + & + & + & $\oplus$ & $\odot$ \\
\hline Chainani-Wu 2007 & + & $?$ & + & + & + & $\Theta$ & + \\
\hline Conrotto 2006 & $\odot$ & $\odot$ & $?$ & $\odot$ & $\odot$ & $\odot$ & $\odot$ \\
\hline Corrocher 2008 & + & $?$ & 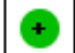 & $\odot$ & $\odot$ & $\oplus$ & $\odot$ \\
\hline Dillenburg 2014 & + & $?$ & $\theta$ & O & $\theta$ & - & + \\
\hline Ezzatt 2019 & + & + & + & + & + & + & + \\
\hline Fu 2012 & + & $?$ & $?$ & $?$ & + & $\oplus$ & $\odot$ \\
\hline Ghabanchi 2009 & $?$ & $?$ & - & - & $\odot$ & $\odot$ & $\odot$ \\
\hline Gorouhi 2007 & + & $\odot$ & $\theta$ & $\theta$ & $\odot$ & + & $\odot$ \\
\hline Hashem 2019 & $?$ & $?$ & $?$ & ? & $\odot$ & + & $\odot$ \\
\hline Hegarty 2002 & + & + & $\theta$ & $\theta$ & + & + & + \\
\hline Hesen 2017 & + & $\odot$ & $?$ & - & + & $\odot$ & $\odot$ \\
\hline Hettiarachchi 2017 & + & $\odot$ & + & + & $\odot$ & $\odot$ & $\odot$ \\
\hline Kia 2015 & + & $?$ & $?$ & + & + & + & $\odot$ \\
\hline
\end{tabular}


Figure 3. (Continued)

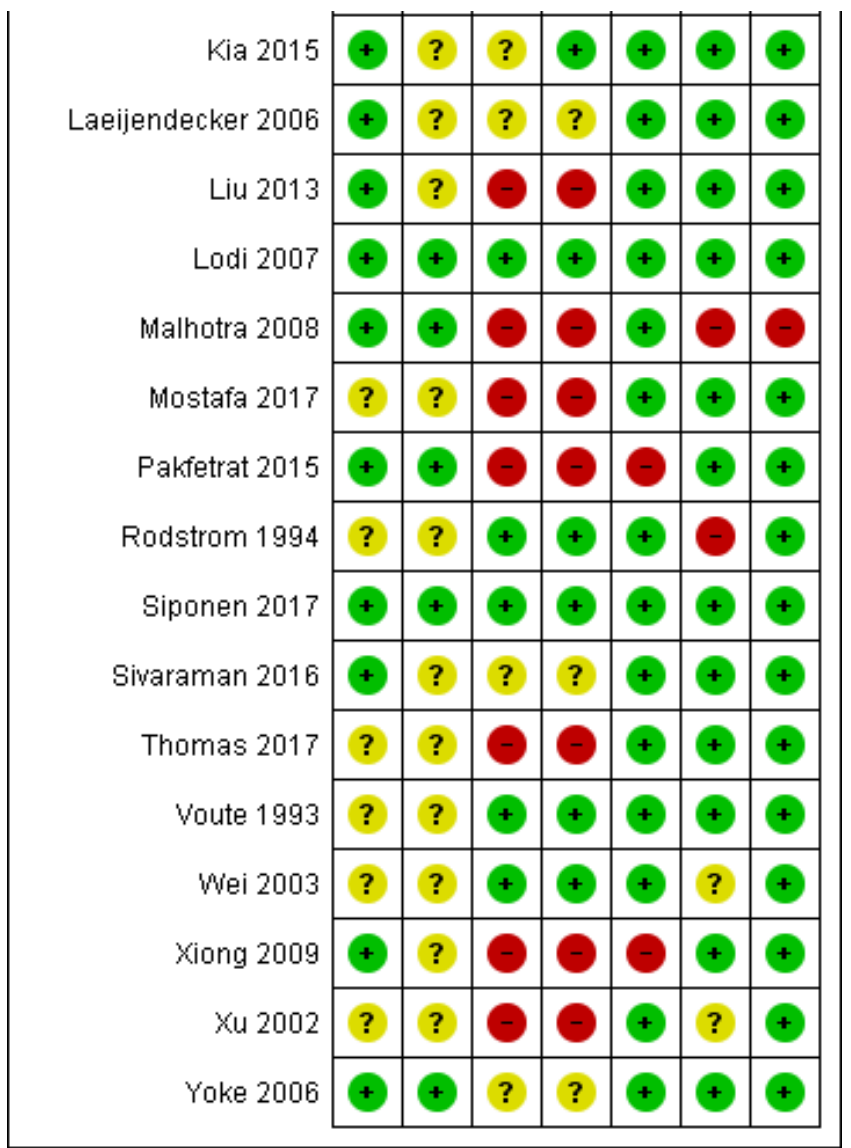

\section{Effects of interventions}

See: Summary of findings for the main comparison Corticosteroids compared to placebo for treating oral lichen planus; Summary of findings $\mathbf{2}$ Corticosteroids versus calcineurin inhibitors for treating oral lichen planus

\section{Corticosteroids versus placebo}

Three studies compared the effects of a corticosteroid with a placebo. The active treatments were flucinonide (Voute 1993), triamcinolone acetonide (Siponen 2017), and clobetasol propionate (Arduino 2018). All studies employed topical corticosteroids that were characterised by adhesive formulations, allowing longer contact with oral mucosa. In Arduino 2018, both arms received miconazole gel once a day plus $0.12 \%$ chlorhexidine mouthrinse twice a day, thus, although not strictly placebocontrolled, we considered it correct to include it in this comparison.

The effectiveness data of Siponen 2017 were not reported in a way that allowed us to perform quantitative analysis.

\section{Pain score}

One study measured pain score on a 0 to 10 scale (Arduino 2018). Clobetasol propionate had a higher rate of pain control than placebo (MD $-1.81,95 \% \mathrm{Cl}-3.54$ to -0.09 ; 1 study, 32 participants; low-certainty evidence; Analysis 1.1).

\section{Pain resolution}

Two studies measured pain resolution (Arduino 2018; Voute 1993). Topical corticosteroids were more likely than placebo to resolve pain (RR 1.91 , $95 \% \mathrm{Cl} 1.08$ to $3.36 ; 2$ studies, 72 participants; $1^{2}=0 \%$; low-certainty evidence; Analysis 1.2).

\section{Clinical score}

One study measured clinical score as continuous data, based on Thongprasom's signs (Arduino 2018). There seemed to be little or no difference in clinical score between clobetasol propionate and placebo (MD $-0.38,95 \% \mathrm{Cl}-0.89$ to $0.14 ; 1$ study, 32 participants; low-certainty evidence; Analysis 1.3).

\section{Clinical resolution}

Two studies comparing a corticosteroid with a placebo considered clinical resolution (Arduino 2018; Voute 1993), but the findings were inconclusive (RR $6.00,95 \% \mathrm{Cl} 0.76$ to $47.58 ; 2$ studies, 72 participants; $I^{2}=0 \%$; very low-certainty evidence; Analysis 1.4).

\section{Adverse effects}

Neither flucinonide nor placebo caused any adverse effects in Voute 1993. In Arduino 2018 and Siponen 2017, the number of participants experiencing adverse effects were similar in both arms of the trials. Arduino 2018 reported one case of gastro-oesophageal reflux in the corticosteroid group (clobetasol propionate) and a severe skin reaction in the placebo group (possibly due to the antimycotic drug). Both participants left the study for this reason. Siponen 2017 
reported that $43 \%$ of participants taking triamcinolone acetonide and 33\% taking placebo experienced local adverse effects. Adverse effects reported with triamcinolone included "smarting sensation" in the mouth and tenderness in the gingiva, while placebo users reported burning and sensitivity to hot food or drink, soreness of the gingiva, and increased salivary flow after applying the paste (RR $1.48,95 \% \mathrm{Cl} 0.48$ to $4.56 ; 3$ studies, 88 participants; $I^{2}=0 \%$; very lowcertainty evidence; Analysis 1.5).

\section{Corticosteroids versus calcineurin inhibitors}

Eleven studies compared a corticosteroid with a calcineurin inhibitor, in particular they compared: clobetasol propionate with ciclosporin (Conrotto 2006), clobetasol propionate with tacrolimus (Corrocher 2008; Hettiarachchi 2017; Sivaraman 2016), triamcinolone acetonide with pimecrolimus (Arunkumar 2015; Gorouhi 2007; Pakfetrat 2015), triamcinolone acetonide with tacrolimus (Laeijendecker 2006; Siponen 2017; Sivaraman 2016), triamcinolone acetonide with ciclosporin (Yoke 2006), and betamethasone $0.1 \%$ gel with pimecrolimus $1 \%$ gel (Ezzatt 2019).

The effectiveness data of Ezzatt 2019, Pakfetrat 2015, and Siponen 2017 were not reported in a way that allowed us to perform quantitative analysis.

\section{Pain score}

Four studies comparing a corticosteroid with a calcineurin inhibitor measured pain by VAS as a continuous value: clobetasol cream versus tacrolimus cream (Hettiarachchi 2017); triamcinolone acetonide in Orabase versus ciclosporin mouthwash (Yoke 2006); and triamcinolone acetonide paste versus pimecrolimus paste (Arunkumar 2015; Gorouhi 2007). None of the studies showed a difference between the two treatments in terms of mean pain values (low- to very low-certainty evidence; Analysis 2.1).

\section{Pain resolution}

Three studies comparing a corticosteroid with a calcineurin inhibitor reported pain resolution (Conrotto 2006; Corrocher 2008; Hettiarachchi 2017). Conrotto 2006 found no evidence of a difference between clobetasol propionate and ciclosporin in the same adhesive gel (RR 2.11, $95 \% \mathrm{Cl} 0.76$ to 5.86; 39 participants; very low-certainty evidence; Analysis 2.2). Two studies found that people treated with clobetasol propionate reported pain resolution less frequently compared with those treated with topical tacrolimus (RR $0.45,95 \% \mathrm{Cl} 0.24$ to $0.88 ; 100$ participants; $\mathrm{I}^{2}=80 \%$; very low-certainty evidence; Analysis 2.2).

\section{Clinical score}

Three studies comparing a steroid with a calcineurin inhibitor measured clinical score: Arunkumar 2015 and Gorouhi 2007 compared triamcinolone acetonide paste with pimecrolimus paste and Hettiarachchi 2017 compared clobetasol propionate cream with tacrolimus cream. Neither of the comparisons showed evidence of a difference between the two treatments in terms of clinical score (low to very low-certainty evidence; Analysis 2.3).

\section{Clinical resolution}

Four studies comparing a corticosteroid with a calcineurin inhibitor measured clinical resolution (Analysis 2.4; Conrotto 2006; Corrocher 2008; Laeijendecker 2006; Sivaraman 2016).
Conrotto 2006 found a better rate of clinical resolution among participants treated with clobetasol propionate gel compared with ciclosporin gel (RR 3.16, $95 \% \mathrm{Cl} 1.00$ to 9.93 ; 39 participants; very low-certainty evidence).

Pooled data from Corrocher 2008 and Sivaraman 2016 showed that participants treated with clobetasol reported clinical resolution less frequently compared with those treated with topical tacrolimus (RR $0.61,95 \% \mathrm{Cl} 0.38$ to $0.99 ; 2$ studies, 52 participants; $\mathrm{I}^{2}=95 \%$; very low-certainty evidence). The high heterogeneity, also found for pain resolution, was difficult to explain, as the two studies were very similar. The main difference was related to drug dosage. In Corrocher 2008, participants applied them four times a day for four weeks, while in Hettiarachchi 2017, application was only two times a day for three weeks. One possibility was that tacrolimus may benefit more than clobetasol from frequent applications.

Pooled data from Laeijendecker 2006 and Sivaraman 2016 showed no evidence of a difference between triamcinolone acetonide ointment and tacrolimus ointment (RR $0.86,95 \% \mathrm{Cl} 0.55$ to 1.35 ; 2 studies, 60 participants; $I^{2}=83 \%$; very low-certainty evidence). We do not know why there was such high heterogeneity between the two studies. It is not possible to reliably investigate causes of heterogeneity when there are only two studies.

\section{Adverse effects}

Seven studies that compared a topical corticosteroid with a topical calcineurin inhibitor reported adverse effects. One study reported that there were no adverse effects in either group (very low-certainty evidence) (Hettiarachchi 2017). One study, comparing clobetasol propionate and ciclosporin, showed a higher incidence of adverse effects among participants treated with the corticosteroid (low-certainty evidence) (Conrotto 2006). All the other studies showed higher incidence of adverse effects in the calcineurin inhibitor group (Corrocher 2008; Gorouhi 2007; Laeijendecker 2006; Siponen 2017; Yoke 2006).

The pooled data of two studies comparing triamcinolone acetonide with tacrolimus showed a higher incidence of adverse effects among participants treated with tacrolimus (RR $0.47,95 \% \mathrm{Cl} 0.22$ to $0.99 ; 2$ studies, 58 participants; $I^{2}=0 \%$; very low-certainty evidence; Analysis 2.5; Laeijendecker 2006; Siponen 2017).

The most frequently reported adverse effects were transient burning or stinging associated with application, and some participants also reported dyspepsia, skin rashes, local swelling and gastrointestinal upsets. Conrotto 2006 reported an increased burning sensation in the tacrolimus group that reduced as the lesions healed.

Notably, one study, conducted in Italy between 1999 and 2002, compared costs, which were considerably less for the corticosteroid (ciclosporin EUR 1.82 per day and clobetasol EUR 0.35 per day (Conrotto 2006).

\section{Corticosteroid A versus corticosteroid B}

Eight studies compared two corticosteroids or the same corticosteroid with different modalities (Campisi 2004; Carbone 2009; Ghabanchi 2009; Hegarty 2002; Liu 2013; Malhotra 2008; Rodstrom 1994; Sivaraman 2016). In particular, they compared two different formulations of clobetasol (Campisi 2004); two clobetasol ointments with different concentrations (Carbone 
2009); betamethasone with triamcinolone (Liu 2013; Malhotra 2008); clobetasol with triamcinolone (Rodstrom 1994; Sivaraman 2016); prednisolone with triamcinolone (Ghabanchi 2009); and fluticasone with betamethasone (Hegarty 2002).

For two studies, data were not suitable for quantitative analysis (Ghabanchi 2009; Hegarty 2002).

\section{Pain score}

Three studies comparing different corticosteroids measured pain score (Campisi 2004; Carbone 2009; Liu 2013). Carbone 2009 compared two different concentrations of clobetasol ointment and found no difference between $0.025 \%$ and $0.05 \%$ formulations (MD $0.26,95 \% \mathrm{Cl}-1.42$ to $0.90 ; 30$ participants; low-certainty evidence). Campisi 2004 compared two different formulations of topical clobetasol propionate and showed that participants treated with $0.025 \%$ microspheres of clobetasol reported significantly less pain in comparison with standard ointment at the same concentration (MD 1.83, 95\% Cl 0.80 to 2.86; 45 participants). Liu 2013 compared two different intralesional corticosteroids (betamethasone and triamcinolone acetonide), and found no evidence in terms of pain reduction between the two groups (MD $-0.41,95 \% \mathrm{Cl}-1.47$ to 0.65 ; 59 participants; low-certainty evidence).

\section{Pain resolution}

One study that compared systemic betamethasone and topical triamcinolone acetonide showed no evidence of a difference in pain resolution between the two treatments (RR 1.04, 95\% Cl 0.60 to 1.80 ; 49 participants; very low-certainty evidence; Analysis 3.2 ) (Malhotra 2008).

\section{Clinical score}

Four studies comparing steroids included clinical score (Campisi 2004; Carbone 2009; Liu 2013; Malhotra 2008).

Carbone 2009 compared two different concentrations of clobetasol propionate ointment, and showed no difference between $0.025 \%$ and $0.05 \%$ formulations (MD $0.47,95 \% \mathrm{Cl}-0.26$ to $1.20 ; 30$ participants; low-certainty evidence; Analysis 3.3). Campisi 2004 compared two different formulations of topical clobetasol, and showed no difference between participants treated with $0.025 \%$ microspheres of clobetasol and those treated with standard clobetasol $0.025 \%$ (MD $0.00,95 \% \mathrm{Cl}-0.61$ to $0.61 ; 45$ participants; Analysis 3.3). Malhotra 2008 compared systemic betamethasone and topical triamcinolone acetonide, showing a better clinical score among participants treated with topical triamcinolone acetonide (MD 1.13, 95\% Cl 0.09 to 2.17; 46 participants; very low-certainty evidence; Analysis 3.3). In contrast, Liu 2013 found in favour of intralesional betamethasone over triamcinolone acetonide when measuring clinical improvement at 14 days (MD 9.77, 95\% $\mathrm{Cl} 0.81$ to 18.73; 59 participants; very low-certainty evidence).

\section{Clinical resolution}

Five studies comparing steroids included clinical resolution (Campisi 2004; Carbone 2009; Liu 2013; Rodstrom 1994; Sivaraman 2016).

Carbone 2009 compared two different concentrations of clobetasol ointment and showed no evidence of a difference between $0.025 \%$ and $0.05 \%$ formulations (RR $1.14,95 \% \mathrm{Cl} 0.56$ to $2.35 ; 30$ participants; very low-certainty evidence). Campisi 2004 compared two different formulations of topical clobetasol and showed no evidence of a difference between participants treated with $0.025 \%$ microspheres of clobetasol and those treated with standard clobetasol $0.025 \%$. Liu 2013 compared two different intralesional corticosteroids (betamethasone and triamcinolone acetonide) and showed a better resolution rate among participants treated with betamethasone (RR 1.40, 95\% Cl 1.06 to 1.83; 59 participants; lowcertainty evidence). Two studies compared clobetasol propionate ointment with triamcinolone acetonide ointment (Rodstrom 1994; Sivaraman 2016): the pooled data showed that participants treated with clobetasol were more likely to achieve clinical resolution (RR 1.56, 95\% Cl 1.09 to $2.21 ; 2$ studies, 57 participants; $I^{2}=$ 96\%; low-certainty evidence) (Analysis 3.4). There was very high heterogeneity. In one study, all participants experienced clinical resolution.

\section{Adverse effects}

Five studies provided data on adverse effects. In Carbone 2009, there were no adverse effects in either group. In Campisi 2004, the two formulations of clobetasol propionate caused adverse effects with similar frequency. In Malhotra 2008, oral betamethasone caused significantly more adverse effects than triamcinolone oral paste. In Rodstrom 1994, three participants had adverse effects, all from the clobetasol group (they did not complete the study). Liu 2013 reported only one participant with adverse effects in the intralesional betamethasone group (Analysis 3.5). The evidence from these studies was low to very low certainty.

\section{Corticosteroids versus other treatments}

Nine studies compared one corticosteroid with another treatment: two compared local corticosteroids, namely dexamethasone mouthrinse and triamcinolone acetonide in Orabase, with photodynamic therapy (Bakhtiari 2017; Mostafa 2017); two compared triamcinolone acetonide cream with curcumin paste (Kia 2015; Thomas 2017); one split-mouth study compared triamcinolone acetonide cream with cryotherapy (Amanat 2014); one compared triamcinolone acetonide cream with local injections with Bacillus Calmette-Guerin polysaccharide nucleic acid (BCGPSN) (Xiong 2009); one compared clobetasol propionate ointment with low-level laser therapy (LLLT) (Dillenburg 2014); one compared dexamethasone ointment with amlexanox paste (Fu 2012); and one compared triamcinolone acetonide gel with hyaluronic acid gel (Hashem 2019).

\section{Pain score}

All nine studies comparing one corticosteroid with another treatment reported pain score. There was very low-certainty evidence that three local treatments may have achieved better pain control than local corticosteroids, namely LLLT (MD 0.62, 95\% CI 0.42 to 0.82 ; 1 study, 42 participants; Analysis 4.1 ), photodynamic therapy (MD 4.90, 95\% Cl 2.98 to 6.82; 1 study, 20 participants; Analysis 4.1) and cryotherapy (MD 1.48, $95 \% \mathrm{Cl} 0.58$ to 2.38 ; 1 study, 52 participants; Analysis 4.2). Topical triamcinolone acetonide achieved better pain control than topical curcumin (MD - $0.64,95 \%$ $\mathrm{Cl}-1.19$ to $-0.10 ; 2$ studies, 100 participants; $\mathrm{I}^{2}=0 \%$; low-certainty evidence). For the other treatments, there were no differences (moderate- to very low-certainty evidence). 


\section{Pain resolution}

Fu 2012 compared dexamethasone ointment with amlexanox paste and found no difference in pain resolution between the two treatments ( $\mathrm{RR} 0.75,95 \% \mathrm{Cl} 0.34$ to $1.66,36$ participants; very lowcertainty evidence) (Analysis 4.3).

\section{Clinical score}

All nine studies comparing one corticosteroid with another treatment reported clinical score. Two treatments obtained a better clinical improvement than local corticosteroids, namely LLLT (MD 0.56, 95\% Cl 0.50 to $0.62 ; 42$ participants; very low-certainty evidence; Dillenburg 2014), and photodynamic therapy (MD 1.52, $95 \% \mathrm{Cl} 0.17$ to $2.87 ; 20$ participants; low-certainty evidence; Mostafa 2017). For the other treatments, there were no differences (low- to very low-certainty evidence) (Analysis 4.4; Analysis 4.5).

\section{Clinical resolution}

Five studies comparing one corticosteroid with another treatment reported clinical resolution (Amanat 2014; Bakhtiari 2017; Dillenburg 2014; Fu 2012; Kia 2015). One treatment, LLLT, achieved a better clinical resolution rate than local corticosteroid (RR 0.46 , $95 \% \mathrm{Cl} 0.22$ to 0.98 ; 42 participants; very low-certainty evidence; Analysis 4.6; Dillenburg 2014). For the other treatments, there were no differences (low- to very low-certainty evidence; Analysis 4.6; Analysis 4.7).

\section{Adverse effects}

Five studies provided data on adverse effects (Amanat 2014; Dillenburg 2014; Fu 2012; Kia 2015; Xiong 2009). In one study, there were no adverse events in any group (Kia 2015). Cryotherapy caused significantly more adverse events than triamcinolone (Analysis 4.9; Amanat 2014). In the other studies, the two treatments caused the same type of adverse effects with similar frequency (Analysis 4.8). The evidence was from low to very-low certainty.

\section{Adjunctive treatment to corticosteroids}

Six studies investigated the putative benefits of treatments adjunctive to corticosteroids. Two studies investigated the effect of antifungals, with the aim of improving OLP or preventing candidosis secondary to local immunosuppression, or both: one compared dexamethasone with and without nystatin (Wei 2003), and the other compared clobetasol propionate gel with and without miconazole gel (Lodi 2007). One study compared dexamethasone mouthwash $(0.5 \%)$ plus nystatin suspension, with or without curcumin tablets (Amirchaghmaghi 2016). One study compared triamcinolone with or without systemic glucosamine sulphate (Hesen 2017).

One study was designed to assess the effect of adjunctive treatment with curcuminoids (compounds found to have anti-inflammatory effects and used in Ayurvedic medicine (one of the world's oldest holistic healing systems developed in India)) in people also receiving treatment with oral prednisone (Chainani-Wu 2007). This study planned to recruit 100 participants but recruitment stopped after a planned interim analysis showed no difference between the adjunctive curcuminoid and placebo groups.

One study compared an unusual three-stage treatment integrating Western and Chinese medicine, with a two-stage Western medicine approach. Western-Chinese included topical application of herbal pulvis, herbal decoction together with oral corticosteroid (prednisone), oral antihistamine (chlorphenamine) and vitamin C using gradually decreasing doses, followed by herbal decoction alone. The comparison group received prednisone, chlorphenamine and vitamin $\mathrm{C}$ in fixed dose, followed by a phase of gradually decreasing dosage (Xu 2002).

\section{Pain score}

Three studies investigating adjunctive treatment with corticosteroids included pain measured by VAS as a continuous value. There was no benefit of miconazole, curcumin or glucosamine sulphate in terms of pain relief (Analysis 5.1; Amirchaghmaghi 2016; Hesen 2017; Lodi 2007). The evidence was from low to very low certainty.

\section{Pain resolution}

None of the studies investigating adjunctive treatment with corticosteroids included pain resolution as a dichotomous outcome.

\section{Clinical score}

Three studies investigating adjunctive treatment with corticosteroids included clinical score. Lodi 2007 found no difference in the percentage of oral mucosa affected between the adjunctive antifungal and steroid-only groups. Amirchaghmaghi 2016 and Hesen 2017 found no difference in terms of Thongprasom score (Thongprasom 1992) between the two groups, with or without adjunctive treatment (Analysis 5.2). The evidence was from low to very low certainty.

Xu 2002 found a benefit favouring the integrated Chinese and Western medicine that just attained statistical significance, although this study was at high risk of bias.

\section{Clinical resolution}

Two studies investigating adjunctive treatment with corticosteroids included clinical resolution (Amirchaghmaghi 2016; Wei 2003). Neither study found a difference in the number of participants in each group reporting clinical resolution (Analysis 5.3). The evidence was very-low certainty.

\section{Adverse effects}

Two studies investigating adjunctive treatment with corticosteroids reported adverse effects. One study recorded no adverse effects in either group (Amirchaghmaghi 2016), while the other reported five cases of candidosis among the 15 participants of the group without antifungal compared with no cases in the group with antifungal (Lodi 2007) (Analysis 5.4). The evidence was of low certainty.

\section{DISCUSSION}

\section{Summary of main results}

The main objective of this review was to evaluate the efficacy of corticosteroids to treat people with symptoms of OLP. We included participants with symptoms only, as presence of pain is the main indication for OLP treatment, and for this reason, pain was the primary outcome of this review, measured as resolution of symptoms or change in pain score. The efficacy of corticosteroid 
treatments was also evaluated on the basis of resolution of clinical lesions and change in clinical score. We also considered adverse effects of treatments.

We included 35 RCTs in our review. We assessed seven studies at overall low risk of bias, 10 studies at unclear risk and the remaining 18 at high risk.

Three studies compared a topical corticosteroid with a placebo. The corticosteroids used in the studies were flucinonide, triamcinolone acetonide and clobetasol propionate, all in adhesive preparations. Pain resolution was more common among participants treated by topical corticosteroids than those receiving placebo. As reported in Summary of findings for the main comparison, the certainty of evidence as measured according to GRADE criteria was low. We found no evidence of a difference between topical steroids and placebo when measuring clinical resolution. Adverse effects caused by topical steroids were not significant in terms of frequency or severity. The certainty of the evidence assessed was very low for clinical resolution and adverse effects.

Twelve studies compared a corticosteroid with a calcineurin inhibitor; in particular, clobetasol propionate versus ciclosporin (one study); clobetasol propionate versus tacrolimus (three studies); triamcinolone acetonide versus pimecrolimus (three studies); triamcinolone acetonide versus tacrolimus (three studies); triamcinolone acetonide versus ciclosporin (one study) and betamethasone versus pimecrolimus (one study). We were able to conduct meta-analyses for studies comparing clobetasol propionate versus tacrolimus (outcomes: pain resolution, clinical resolution and adverse effects) and studies comparing triamcinolone acetonide versus tacrolimus (outcomes: clinical resolution and adverse effects). Pain resolution and clinical resolution were significantly more frequent among participants treated with topical tacrolimus compared with clobetasol propionate, with the certainty of evidence assessed according to GRADE being very low (Summary of findings 2). Two studies only compared clinical resolution among participants treated with triamcinolone acetonide and tacrolimus, showing conflicting results; the pooled data indicated no significant benefit among participants treated with tacrolimus; however, such results must be carefully interpreted because of the very low certainty of the evidence assessed according to GRADE (Summary of findings 2). One study showed higher incidence of adverse effects in participants treated with corticosteroids when compared to calcineurin inhibitors, while all the other studies showed higher incidence of adverse effects in the calcineurin inhibitor group (lowto very low-certainty evidence).

The results for calcineurin inhibitors should be also considered with caution and the benefits and adverse effects of this class of medication on OLP will be scrutinised in more in depth scrutinised our the sister review on non-corticosteroids.

Twenty-three studies compared either two corticosteroids or the same corticosteroid in different modalities (eight studies), or one corticosteroid with another treatment (nine studies), or treatments adjunctive to corticosteroids (six studies). Although no corticosteroid or formulation has proven to be convincingly superior, single trials suggest that low-level laser, cryotherapy and photodynamic therapy may be superior to topical corticosteroids (low- to very low-certainty evidence). One single trial at high risk of bias has also reported benefit from integrating traditional Chinese medicine with corticosteroids (very low-certainty evidence).

Although not negligible (Varoni 2012), systemic absorption of topical corticosteroids throughout oral mucosa is less likely to cause the adverse events characteristic of long-term use of such drugs, particularly in those due to adrenal suppression. For this reason, topical application is considered the preferable approach for first-line corticosteroid treatment of OLP.

\section{Overall completeness and applicability of evidence}

In this review, we presented the evidence regarding the effects of corticosteroids, mainly used in topical preparations, in treating people affected by symptomatic OLP.

The studies included in the review investigated the efficacy of a large number of systemic and topical corticosteroids, including some of the drugs most frequently used as first-line treatment, such as clobetasol propionate and triamcinolone acetonide. In this updated version of the review, we identified three placebocontrolled trials of corticosteroids of different potencies, namely triamcinolone acetonide, flucinonide and clobetasol propionate, for treating symptomatic OLP, which showed some benefit. Interestingly, all three corticosteroids were delivered in adhesive creams. Because of high variability in corticosteroid formulation, concentration or dosage regimen among studies, it is difficult to evaluate and compare them, and to meta-analyse data. Interestingly, topical corticosteroids seem to be more effective than most other treatment modalities except topical tacrolimus. However, when it comes to clinical response, the benefit of topical tacrolimus over topical corticosteroids is less clear and more better-conducted trials are clearly warranted. Moreover, topical tacrolimus seems to cause more adverse effects than corticosteroids and there is some concern that this drug could increase the risk of malignant transformation of OLP (Becker 2006; Mattsson 2010).

Thirty of 35 included studies measured pain, which was the primary outcome of this review as it is most often the reason that people seek treatment. Measuring pain in clinical trials of treatments for OLP is difficult due to the fluctuating nature of OLP pain and variations between participants. In addition, pain scores may be influenced by the timing of the evaluation: assessments at different times of the day (e.g. between meals, while eating or while performing oral care) may give rise to different pain scores. Moreover, the impact of pain on physical, emotional and social functions may require multidimensional qualitative tools and health-related quality of life instruments that are uncommonly used in OLP trials. For our secondary outcomes, $100 \%$ of studies measured clinical presentation and $62 \%$ measured adverse effects. However, the methods adopted to measure such outcomes were different and often difficult to compare, representing another obstacle to summarising their effects and to meta-analysing data. Less than half $(47 \%)$ of the studies included in this review assessed Improvement of clinical signs of OLP using the same clinical criteria score (one devised by Thongprasom 1992). The remaining studies used a variety of assessments. The lack of a widely accepted system for scoring the clinical severity of OLP makes it difficult to compare the effectiveness of drugs within and between individuals, and between different institutions. Therefore, clinical assessment criteria should be established and accepted by clinicians before further RCTs are undertaken. 
Due to the chronic nature of OLP and the impact of this condition on quality of life, the use of patient-reported outcome measures (PROMs) in assessing the treatment of chronic oral mucosal diseases is of great importance (Ní Ríordáin 2015). For this reason, the next update of this review will include PROMs among primary outcome measures.

Because of small sample size in many trials, it is likely that there was a lack of power to detect differences between treatments, if indeed such a difference existed.

The evidence for corticosteroids should have reasonable applicability as the included studies reported data from participants from different countries. In addition, our criteria limited the inclusion in the review, to studies enrolling participants who can benefit from corticosteroid treatment, that is, affected by symptomatic OLP, with the typical clinical features of people attending the majority of oral medicine services.

\section{Quality of the evidence}

Seven studies were at overall low risk of bias (Amirchaghmaghi 2016; Arduino 2018; Carbone 2009; Ezzatt 2019; Hettiarachchi 2017; Lodi 2007; Siponen 2017). Seventeen included studies were at high risk of bias: 15 for detection or performance bias (blinding), four for attrition bias, seven for reporting bias and one for 'other potential sources of bias', because of differences between groups in clinical score at baseline (Malhotra 2008).

When assessed using the GRADE method (Atkins 2004), the overall certainty of the evidence from placebo-controlled studies was low to very low due to the small number of participants and relatively large $\mathrm{Cls}$, risk of bias and high heterogeneity (Summary of findings for the main comparison). Likewise, for studies comparing topical corticosteroids with topical calcineurin inhibitors, the certainty of the evidence varied from low to very low, mainly due to heterogeneity, risk of bias, small number of participants and large Cls (Summary of findings 2).

\section{Potential biases in the review process}

We have taken steps to minimise the bias in every step of the review. We searched databases and trial registries with no language limitations to identify all the relevant reports. We tried to contact the study authors for missing data through e-mails. We provided a narrative description of trials with data that did not allow quantitative analysis.

\section{Agreements and disagreements with other studies or reviews}

Most published reviews, both systematic and narrative, on OLP management consider topical corticosteroids to be the most useful agents for the treatment of this disease (e.g. Al-Hashimi 2007; Carrozzo 2009; Cribier 1998; Le Cleach 2012).

Chamani 2015, a systematic review and meta-analysis including 10 studies, assessed the efficacy of tacrolimus and clobetasol in the treatment of OLP. Three out of 10 studies directly compared clobetasol with tacrolimus and two found this drug more effective than the topical corticosteroid, which is similar to the findings of our systematic review.
Another systematic review assessed the efficacy of any form of intervention used to medically manage OLP and included 29 clinical trials using corticosteroid as an active intervention (Suresh 2016). Conclusions suggest that betamethasone valerate, fluocinonide and clobetasol propionate are more effective than placebo. Whereas these conclusions are, generally speaking, in agreement with our review, it should be emphasised that the inclusion criteria of the Suresh 2016 review were significantly different from our review and the results were mainly reported in a descriptive way. The review stated that it fulfils the PRISMA checklist (Moher 2009); however, reporting of the data collection process and data items were unclear and no meta-analysis was attempted (Suresh 2016).

Two systematic reviews compared the efficacy of LLLT in OLP to that of topical corticosteroids (Akram 2018; Al-Maweri 2018). Both reviews selected the same three RCTs, only one of which was included in our review (Dillenburg 2014). We excluded the other two RCTs: Jajarm 2011 enrolled participants without symptoms, and Kazancioglu 2015 did not use corticosteroids. Akram 2018 also considered two non-RCTs. The reviews reached different conclusions: Al-Maweri 2018 stated that LLLT is effective and can be used as an alternative to corticosteroids; Akram 2018 concluded that is unclear whether LLLT is more or as effective as topical corticosteroids in OLP management. Our review concords with the latter, as we found little evidence that LLLT is better than TCs.

Another review has systematically evaluated the efficacy of aloe vera in comparison to triamcinolone acetonide paste in the management of OLP (Ali 2017). It concluded that they showed comparable effectiveness. The review included two RCTs (Mansourian 2011; Reddy 2012). Notably, neither of these studies is included in our review because they enrolled participants without symptoms (Characteristics of excluded studies table).

\section{AUTHORS' CONCLUSIONS}

\section{Implications for practice}

We identified 35 randomised controlled trials (RCTs) testing corticosteroids for the treatment of people with symptoms of oral lichen planus (OLP), three of them comparing a topical drug to placebo. Low-certainty evidence suggested that corticosteroids, particularly in topical formulations with adhesive bases, are effective in controlling pain of OLP, though the findings were inconclusive for improving clinical presentation and we are uncertain about adverse effects. There is very low-certainty evidence that the calcineurin inhibitor tacrolimus may be more effective than a corticosteroid for reducing pain, but maybe more likely to have mild adverse effects, and clinical response to tacrolimus compared with corticosteroid showed conflicting results. There is no convincing evidence that one steroid treatment is better or worse than another.

\section{Implications for research}

Better intervention trials comparing different topical corticosteroids and corticosteroids with calcineurin inhibitors are still needed. Future trials should compare different doses and treatment lengths, particularly in terms of long-term relapses and adverse effects. In addition, future trials should standardise research methods, in particular, assessment methods for the main outcomes: pain and clinical presentation. Sample size should be 
preliminary and properly calculated to avoid lack of power to detect differences between treatments.

\section{ACKNOWLEDGEMENTS}

We thank Laura MacDonald, Anne Littlewood, Prof Sumanth Kumbargere Nagraj, Dr Philip Riley, Janet Lear, Professor Jan Clarkson and Professor Helen Worthington of Cochrane Oral Health, Dr Nuala Livingston, Dr Stefano Fedele and Anne Lawson.
We thank authors of cited studies who provided data used in the review.

For their input to previous versions of this review, we thank Luisa Fernandez-Mauleffinch, Jo Weldon, Susan Furness and Professor Kobkan Thongprasom. 


\section{R E F E R E N C E S}

\section{References to studies included in this review}

Amanat 2014 \{published data only\}

Amanat D, Ebrahimi H, Zahedani MZ, Zeini N, Pourshahidi S, Ranjbar Z. Comparing the effects of cryotherapy with nitrous oxide gas versus topical corticosteroids in the treatment of oral lichen planus. Indian Journal Dental Research 2014;25:711-6.

\section{Amirchaghmaghi 2016 \{published data only\}}

Amirchaghmaghi M, Pakfetrat A, Delavarian Z, Ghalavani H, Ghazi A. Evaluation of the efficacy of curcumin in the treatment of oral lichen planus: a randomized controlled trial. Journal of Clinal and Diagnostic Research 2016;10:ZC134-7.

\section{Arduino 2018 \{published data only\}}

Arduino PG, Campolongo MG, Sciannameo V, Conrotto D, Gambino A, Cabras M, et al. Randomized, placebo-controlled, double-blind trial of clobetasol propionate $0.05 \%$ in the treatment of oral lichen planus. Oral Diseases 2018;24(5):772-7.

\section{Arunkumar 2015 \{published data only\}}

Arunkumar S, Kalappanavar AN, Annigeri RG, Kalappa SG. Relative efficacy of pimecrolimus cream and triamcinolone acetonide paste in the treatment of symptomatic oral lichen planus. Indian Journal of Dentistry 2015;6:14-9.

\section{Bakhtiari 2017 \{published data only\}}

Bakhtiari S, Azari-Marhabi S, Mojahedi SM, Namdari M, Rankohi ZE, Jafari S. Comparing clinical effects of photodynamic therapy as a novel method with topical corticosteroid for treatment of oral lichen planus. Photodiagnosis and Photodynamic Therapy 2017;20:159-64.

\section{Campisi 2004 \{published data only\}}

Campisi G, Giandalia G, De Caro V, Di Liberto C, Arico P, Giannola LI. A new delivery system of clobetasol-17-propionate (lipid-loaded microspheres $0.025 \%$ ) compared with a conventional formulation (lipophilic ointment in a hydrophilic phase $0.025 \%$ ) in topical treatment of atrophic/erosive oral lichen planus. A phase IV, randomized, observer-blinded, parallel group clinical trial. British Journal of Dermatology 2004;150(5):984-90.

\section{Carbone 2009 \{published data only\}}

Carbone M, Arduino PG, Carrozzo M, Caiazzo G, Broccoletti R, Conrotto D, et al. Topical clobetasol in the treatment of atrophic-erosive oral lichen planus: a randomized controlled trial to compare two preparations with different concentrations. Journal of Oral Pathology \& Medicine 2009;38(2):227-33.

\section{Chainani-Wu 2007 \{published data only\}}

Chainani-Wu N, Silverman S Jr, Reingold A, Bostrom A, Mc Culloch C, Lozada-Nur F, et al. A randomized, placebocontrolled, double-blind clinical trial of curcuminoids in oral lichen planus. Phytomedicine 2007;14(7-8):437-46.

\section{Conrotto 2006 \{published and unpublished data\}}

Conrotto D, Carbone M, Carrozzo M, Arduino P, Broccoletti R, Pentenero M, et al. Ciclosporin vs. clobetasol in the topical management of atrophic and erosive oral lichen planus: a double-blind, randomized controlled trial. British Journal of Dermatology 2006;154(1):139-45.

Corrocher 2008 \{published data only\}

Corrocher G, Di Lorenzo G, Martinelli N, Mansueto P, Biasi D, Nocini PF, et al. Comparative effect of tacrolimus $0.1 \%$ ointment and clobetasol $0.05 \%$ ointment in patients with oral lichen planus. Journal of Clinical Periodontology 2008;35(3):244-9.

Dillenburg 2014 \{published data only\}

Dillenburg CS, Martins MA, Munerato MA, Marques MM, Carrard VC, Sant'Ana Filho M, et al. Efficacy of laser phototherapy in comparison to topical clobetasol for the treatment of oral lichen planus: a randomised controlled trial. Journal of Biomedical Optics 2014;19(6):068002-9.

\section{Ezzatt 2019 \{published data only\}}

Ezzatt OM, Helmy IM. Topical pimecrolimus versus betamethasone for oral lichen planus: a randomized clinical trial. Clinical Oral Investigations 2019;23:947-56.

Fu 2012 \{published data only\}

Fu J, Zhu X, Dan H, Zhou Y, Liu C, Wang F, et al. Amlexanox is effective as dexamethasone in topical treatment of erosive lichen planus: a short-term pilot study. Oral Surgery, Oral Medicine, Oral Pathology, and Oral Radiology 2012;113:638-43.

\section{Ghabanchi 2009 \{published data only\}}

Ghabanchi J, Bahri Najafi R, Haghnegahdar S. Treatment of oral inflammatory diseases with a new mucoadhesive prednisolone table versus triamcinolone acetonide paste. Iranian Red Crescent Medical Journal 2009; Vol. 11, issue 2:155-9.

\section{Gorouhi 2007 \{published data only\}}

Gorouhi F, Solhpour A, Beitollahi JM, Afshar S, Davari P, Hashemi $P$, et al. Randomized trial of pimecrolimus cream versus triamcinolone acetonide paste in the treatment of oral lichen planus. Journal of the American Academy of Dermatology 2007;57(5):806-13.

\section{Hashem 2019 \{published data only\}}

Hashem AS, Issrani R, Elsayed TE, Prabhu N. Topical hyaluronic acid in the management of oral lichen planus: a comparative study. Journal of Investigative and Clinical Dentistry 2019;10:e12385.

\section{Hegarty 2002 \{published data only\}} Hegarty AM, Hodgson TA, Lewsey JD, Porter SR. Fluticasone propionate spray and betamethasone sodium phosphate mouthrinse: a randomized crossover study for the treatment of symptomatic oral lichen planus. Journal of the American Academy of Dermatology 2002;47(2):271-9.

\section{Hesen 2017 \{published data only\}}

Hesen RR, Abuel-Ela HA, Helmy IM, El Sayed MH, Ezzatt OM. Glucosamine as a novel adjunctive therapy in symptomatic oral lichen planus. Journal of Pharmaceutical Sciences and Research 2017;9:941-6 


\section{Hettiarachchi 2017 \{published data only\}}

Hettiarachchi PV, Hettiarachchi RM, Jayasinghe RD, Sitheeque M. Comparison of topical tacrolimus and clobetasol in the management of symptomatic oral lichen planus: a double-blinded, randomized clinical trial in Sri Lanka. Journal of Investigative and Clinical Dentistry 2017;8(4):e12237.

\section{Kia 2015 \{published data only\}}

Kia SJ, Shirazian S, Mansourian A, Khodadadi Fard L, Ashnagar S. Comparative efficacy of topical curcumin and triamcinolone for oral lichen planus: a randomized, controlled clinical trial. Journal of Dentistry (Tehran) 2015;12:789-96.

\section{Laeijendecker 2006 \{published data only\}}

Laeijendecker R, Tank B, Dekker SK, Neumann HA. A comparison of treatment of oral lichen planus with topical tacrolimus and triamcinolone acetonide ointment. Acta Dermato-venereologica 2006;86:227-9.

\section{Liu 2013 \{published data only\}}

Liu C, Xie B, Yang Y, lin D, Wang C, Lin M, et al. Efficacy of intralesional betamethasone for erosive oral lichen planus and evaluation of recurrence: a randomized, controlled trial. Oral Surgery, Oral Medicine, Oral Pathology, and Oral Radiology 2013;116:584-90

\section{Lodi 2007 \{published data only\}}

Lodi G, Tarozzi M, Sardella A, Demarosi F, Canegallo L, Di Benedetto D, et al. Miconazole as adjuvant therapy for oral lichen planus: a double-blind randomized controlled trial. British Journal of Dermatology 2007;156(6):1336-41.

\section{Malhotra 2008 \{published data only\}}

Khaitan BK, Malhotra A, Sharma VK, Sethuraman G. Efficacy and safety of betamethasone oral mini-pulse therapy compared with topical triamcinolone acetonide oral paste in oral lichen planus: a randomized comparative study (Abstract FC03.11). Journal of the of the European Academy of Dermatology and Venereology 2005;19 Suppl 2:12-3.

* Malhotra AK, Khaitan BK, Sethuraman G, Sharma VK. Betamethasone oral mini-pulse therapy compared with topical triamcinolone acetonide $(0.1 \%)$ paste in oral lichen planus: a randomized comparative study. Journal of the American Academy of Dermatology 2008;58(4):596-602.

\section{Mostafa 2017 \{published data only\}}

Mostafa D, Moussa E, Alnouaem M. Evaluation of photodynamic therapy in treatment of oral erosive lichen planus in comparison with topically applied corticosteroids. Photodiagnosis and Photodynamic Therapy 2017;19:56-66.

\section{Pakfetrat 2015 \{published and unpublished data\}}

Pakfetrat A, Delavarian Z, Falaki F, Khorashadizadeh M, Saba $M$. The effect of pimecrolimus cream $1 \%$ compared with triamcinolone acetonide paste in treatment of atrophic-erosive oral lichen planus. Iranian Journal of Otorhinolaryngology 2015;27:119-26.
Rodstrom 1994 \{published and unpublished data\}

* Rodstrom PO, Hakeberg M, Jontell M, Nordin P. Erosive oral lichen planus treated with clobetasol propionate and triamcinolone acetonide in Orabase: a double-blind clinical trial. Journal of Dermatological Treatment 1994;5(1):7-10.

Rodstrom PO, Hakeburg M, Jontell M, Nordin P, et al. Treatment of oral lichen planus by topical application of clobetasol propionate (Dermovat) in Orabase (IADR Abstract 1123). Journal of Dental Research 1992;72:656.

\section{Siponen 2017 \{published data only\}}

Siponen M, Huuskonen L, Kallio-Pulkkinen S, Nieminen P, Salo T. Topical tacrolimus, triamcinolone acetonide, and placebo in oral lichen planus: a pilot randomized controlled trial. Oral Diseases 2017;23:660-8.

\section{Sivaraman 2016 \{published data only\}}

Sivaraman S, Santham K, Nelson A, Laliytha B, Azhalvel P, Deepak $\mathrm{JH}$. A randomized triple-blind clinical trial to compare the effectiveness of topical triamcinolone acetonate $(0.1 \%)$, clobetasol propionate $(0.05 \%)$, and tacrolimus Orabase $(0.03 \%)$ in the management of oral lichen planus. Journal of Pharmacy and Bioallied Sciences 2016;8(Suppl 1):S86-9.

\section{Thomas 2017 \{published data only\}}

Thomas AE, Varma B, Kurup S, Jose R, Chandy ML, Kumar SP, et al. Evaluation of efficacy of $1 \%$ curcuminoids as local application in management of oral lichen planus interventional study. Journal of Clinical and Diagnostic Research 2017;11:ZC89-93.

\section{Voute 1993 \{published data only\}}

Voute AB, Schulten EA, Langendijk PN, Kostense PJ, Van der Waal I. Fluocinonide in an adhesive base for treatment of oral lichen planus. A double-blind, placebo-controlled clinical study. Oral Surgery, Oral Medicine, and Oral Pathology 1993;75(2):181-5

\section{Wei 2003 \{published data only\}}

Wei X, Li BQ, Zhou XD, Chen QM. Clinical effect of mycostatin paste plus dexamethasone paste in treatment of patients with OLP. Journal of Clinical Stomatology 2003;19(9):568-9.

\section{Xiong 2009 \{published data only\}}

Xiong C, Li Q, Lin M, Li X, Meng W, Wu Y, et al. The efficacy of topical intralesional BCG-PSN injection in the treatment of erosive oral lichen planus: a randomized controlled trial. Journal of Oral Pathology and Medicine 2009;38:551-8.

\section{Xu 2002 \{published data only\}}

Xu YZ, Geng Y, Liu YX, Fuan YQ, Li J. Clinical study on threestep treatment of oral lichen planus by integrated traditional and western medicine. Journal of Modern Stomatology 2002;16:344-6.

\section{Yoke 2006 \{published data only\}}

Yoke PC, Tin GB, Kim MJ, Rajaseharan A, Ahmed S, Thongprasom $\mathrm{K}$, et al. A randomized controlled trial to compare steroid with cyclosporine for the topical treatment of oral 
lichen planus. Oral Surgery, Oral Medicine, Oral Pathology, Oral Radiology, and Endodontics 2006;102:47-55.

\section{References to studies excluded from this review}

Agarwal 2013 \{published data only\}

Agarwal S, Gupta G, Sayal SK. Comparative study of the therapeutic efficacy of the dapsone (alone), dapsone plus tacrolimus (topical) and dapsone plus triamcinolone (topical) in oral lichen planus. Indian Journal of Public Health Research and Development 2013;4(1):83-6.

\section{Agha-Hosseini 2010 \{published data only\}}

Agha-Hosseini F, Borhan-Mojabi K, Monsef-Esfahani HR, MirzaiiDizgah I, Etemad-Moghadam S, Karagah A. Efficacy of purslane in the treatment of oral lichen planus. Phytotherapy Research 2010;24(2):240-4.

\section{Amirchaghmaghi 2014 \{published data only\}}

Amirchaghmaghi M, Delavarian Z, Iranshahi M, Shakeri MT, Mozafari PM, Mohammadpour AH, et al. A randomized placebocontrolled double blind clinical trial of quercetin for treatment of oral lichen planus. Journal of Dental Research, Dental Clinics, Dental Prospects 2014;9(1):23-8.

\section{Arbabi-Kalati 2017 \{published data only\}}

Arbabi-Kalati F, Farahmand MM. Evaluation of the efficacy of lycopene in the management of oral lichen planus. Tehran University Medical Journal 2017;75:658-62.

\section{Azizi 2015 \{published data only\}}

Azizi A, Dadras OG, Jafari M, Ghadim NM, Lawaf S, Sadri D. Efficacy of $0.1 \%$ triamcinolone with nanoliposomal carrier formulation in Orabase for oral lichen planus patients: a clinical trial. European Journal of Integrative Medicine 2015;8:275-80.

Bakhtiar 2018 \{published data only\}

Bakhtiar R, Noor SM, Paracha MM. Effectiveness of oral methotrexate therapy versus systemic corticosteroid therapy in treatment of generalised lichen planus. Journal of the College of Physicians and Surgeons--Pakistan : JCPSP 2018;28:505-8.

Boisnic 1994 \{published data only\}

Boisnic S, Branchet MC, Pascal F, Ben Slama L, Rostin M, Szpirglas $\mathrm{H}$. Topical tretinoin in the treatment of lichen planus and leukoplakia of the mouth mucosa. A clinical evaluation. Annales de Dermatologie et de Venereologie 1994;121(6-7):459-63.

\section{Bouloc 2000 \{published data only\}}

Bouloc A, Revuz J, Bagot M, Wechsler J, Natta P. KH 1060 for the treatment of lichen planus: a multicenter, randomized, doubleblind, vehicle-controlled study. Archives of Dermatology 2000; Vol. 136, issue 10:1272.

\section{Buajeeb 1997 \{published data only\}}

Buajeeb W, Kraivaphan P, Pobrurksa C. Efficacy of topical retinoic acid compared with topical fluocinolone acetonide in the treatment of oral lichen planus. Oral Surgery, Oral Medicine, Oral Pathology, Oral Radiology, and Endodontics 1997;83(1):21-5.

\section{Buajeeb 2000 \{published data only\}}

Buajeeb W, Pobrurksa C, Kraivaphan P. Efficacy of fluocinolone acetonide gel in the treatment of oral lichen planus. Oral Surgery, Oral Medicine, Oral Pathology, Oral Radiology, and Endodontics 2000;89(1):42-5.

\section{Chang 2008 \{published data only\}}

Chang AL, Badger J, Rehmus W, Kimball AB. Alefacept for erosive lichen planus: a case series. Journal of Drugs in Dermatology 2008;7(4):339-43.

\section{Choonhakarn 2008 \{published data only\}}

Choonhakarn C, Busaracome P, Sripanidkulchai B, Sarakarn P. The efficacy of aloe vera gel in the treatment of oral lichen planus: a randomized controlled trial. British Journal of Dermatology 2008;158(3):573-7.

\section{Cilurzo 2010 \{published data only\}}

Cilurzo F, Gennari CG, Selmin F, Epstein JB, Gaeta GM, Colella G, et al. A new mucoadhesive dosage form for the management of oral lichen planus: formulation study and clinical study. European Journal of Pharmaceutics and Biopharmaceutics 2010;76(3):437-42.

\section{Delavarian 2010 \{published data only\}}

Delavarian Z, Javadzadeh-Bolouri A, Dalirsani Z, Arshadi HR, Toofani-Asl $\mathrm{H}$. The evaluation of psychiatric drug therapy on oral lichen planus patients with psychiatric disorders. Medicina Oral, Patologia Oral y Cirugia Bucal 2010; Vol. 15, issue 2:e322-7.

Eisen 1990 \{published data only\}

Eisen D, Ellis CN, Duell EA, Griffiths CE, Voorhees JJ. Effect of topical cyclosporine rinse on oral lichen planus. A double-blind analysis. New England Journal of Medicine 1990;323(5):290-4.

Gaeta 1994 \{published data only\}

Gaeta GM, Serpico R, Femiano F, La Rotonda MI, Cappello B, Gombos F. Cyclosporin bioadhesive gel in the topical treatment of erosive oral lichen planus. International Journal of Immunopathology and Pharmacology 1994;7:125-32.

\section{Giustina 1986 \{published data only\}}

Giustina TA, Stewart JC, Ellis CN, Regezi JA, Annesley T, Woo TY, et al. Topical application of isotretinoin gel improves oral lichen planus. A double-blind study. Archives of Dermatology 1986;122(5):534-6.

\section{Glade 1998 \{published data only\}}

Glade CP, Van der Vleuten CJ, Van Erp PE, De Jong EM, Van de Kerkhof PC. The epidermis of chronic idiopathic lichen planus during topical treatment with the vitamin D3 analogue KH 1060. Clinical and Experimental Dermatology 1998;23(1):14-8.

\section{Greenspan 1978 \{published data only\}}

Greenspan JS, Yeoman CM, Harding SM. Oral lichen planus. A double-blind comparison of treatment with betamethasone valerate aerosol and pellets. British Dental Journal 1978;144(3):83-4. 


\section{Gunther 1973 \{published data only\}}

Gunther S. The therapeutic value of retinoic acid (vitamin A acid) in lichen planus of the oral mucous membrane. Dermatologica 1973;147(2):130-6.

\section{Hantash 2007 \{published data only\}}

Hantash BM, Kanzler MH. The efficacy of tetracycline antibiotics for treatment of lichen planus: an open-label clinical trial. British Journal of Dermatology 2007; Vol. 156, issue 4:758-60.

\section{Harpenau 1995 \{published data only\}}

Harpenau LA, Plemons JM, Rees TD. Effectiveness of a low dose of cyclosporine in the management of patients with oral erosive lichen planus. Oral Surgery, Oral Medicine, Oral Pathology, Oral Radiology, and Endodontics 1995;80(2):161-7.

\section{Hersle 1982 \{published data only\}}

Hersle K, Mobacken H, Sloberg K, Thilander H. Severe oral lichen planus: treatment with an aromatic retinoid (etretinate). British Journal of Dermatology 1982;106(1):77-80.

\section{Jajarm 2011 \{published data only\}}

Jajarm HH, Falaki F, Mahdavi O. A comparative pilot study of low intensity laser versus topical corticosteroids in the treatment of erosive-atrophic oral lichen planus. Photomedicine and Laser Surgery 2011;29(6):421-5

\section{Javadzadeh 2008 \{published data only\}}

Javadzadeh A, Vatanpour H, Delavarian Z, Momajed A, Esmaeily $\mathrm{H}$, Vatanpour M, et al. Efficacy of clobetasol, ketoconazole and amitriptyline mouthwash on oral lichen planus. Iranian Journal of Pharmaceutical Research 2008; Vol. 7 , issue 3:171-8.

\section{Joshy 2018 \{published data only\}}

Joshy A, Doggalli N, Patil K, Kulkarni PK. To evaluate the efficacy of topical propolis in the management of symptomatic oral lichen planus: a randomized controlled trial. Contemporary Clinical Dentistry 2018;9(65):71.

\section{Kellett 1990 \{published data only\}}

Kellett JK, Ead RD. Treatment of lichen planus with a short course of oral prednisolone. British Journal of Dermatology 1990; Vol. 123, issue 4:550-1.

\section{Laurberg 1991 \{published data only\}}

Laurberg G, Geiger JM, Hjorth N, Holm P, Hou-Jensen K, Jacobsen KU, et al. Treatment of lichen planus with acitretin. A double-blind, placebo-controlled study in 65 patients. Journal of the American Academy of Dermatology 1991;24(3):434-7.

\section{Lee 2013 \{published data only\}}

Lee YC, Shin SY, Kim SW, Eun YG. Intralesional injection versus mouth rinse of triamcinolone acetonide in oral lichen planus: a randomized controlled study. Otolaryngology and Head and Neck Surgery 2013;148:443-9.

\section{Lin 2005 \{published data only\}}

Lin LM, Qi XM. Comparative observation on the effects of Radix tripterygium hypoglaucum tablet and Tripterygium glycosides tablet in treating erosive oral lichen planus. Chinese Journal of Integrative Medicine 2005;11(2):149-50.

Lundquist 1995 \{published data only\}

Lundquist G, Forsgren H, Gajecki M, Emtestam L.

Photochemotherapy of oral lichen planus. A controlled study. Oral Surgery, Oral Medicine, Oral Pathology, Oral Radiology, and Endodontics 1995;79(5):554-8.

Mansourian 2011 \{published data only\}

Mansourian A, Momen-Heravi F, Saheb-Jamee M, Esfehani M, Khalilzadeh O, Momen-Beitollahi J. Comparison of aloe vera mouthwash with triamcinolone acetonide $0.1 \%$ on oral lichen planus: a randomized double-blinded clinical trial. American Journal of the Medical Sciences 2011;342(6):447-51.

McCaughey 2010 \{published data only\}

McCaughey C, Machan M, Bennett R, Zone J, Hull C.

Pimecrolimus $1 \%$ cream for oral erosive lichen planus: a 6-week randomized, double-blind, vehicle-controlled study with a 6week open-label extension to assess efficacy and safety. Journal of the European Academy of Dermatology and Venereology 2010;25(9):1061-7.

\section{Mirza 2018 \{published data only\}}

Mirza S, Rehmanb N, Alrahlahc A, Alamrid WR, Vohrae F. Efficacy of photodynamic therapy or low level laser therapy against steroid therapy in the treatment of erosive-atrophic oral lichen planus. Photodiagnosis Photodynamic Therapy 2018;21:404-8.

\section{Mostafa 2018 \{published data only\}}

Mostafa B, Zakaria M. Evaluation of combined topical ozone and steroid therapy in management of oral lichen planus. Open Access Macedonian Journal of Medical Science 2018;20:879-84.

Mousavi 2009 \{published data only\}

Mousavi F, Sherafati S, Mojaver YN. Ignatia in the treatment of oral lichen planus. Homeopathy 2009;98(1):40-4.

\section{Nolan 2009 \{published data only\}}

Nolan A, Badminton J, Maguire J, Seymour RA. The efficacy of topical hyaluronic acid in the management of oral lichen planus. Journal of Oral Pathology \& Medicine 2009;38(3):299-303.

\section{Passeron 2007 \{published data only\}}

Passeron T, Lacour JP, Fontas E, Ortonne JP. Treatment of oral erosive lichen planus with $1 \%$ pimecrolimus cream: a doubleblind, randomized, prospective trial with measurement of pimecrolimus levels in the blood. Archives of Dermatology 2007;143(4):472-6.

\section{Radfar 2008 \{published data only\}}

Radfar L, Wild RC, Suresh L. A comparative treatment study of topical tacrolimus and clobetasol in oral lichen planus. Ora Surgery, Oral Medicine, Oral Pathology, Oral Radiology, and Endodontics 2008;105(2):187-93.

Reddy 2012 \{published data only\}

Reddy RL, Reddy RS, Ramesh T, Singh TR, Swapna LA, Laxmi NV. Randomized trial of aloe vera gel vs triamcinolone acetonide 
ointment in the treatment of oral lichen planus. Quintessence International 2012;43(9):793-800.

\section{Riaz 2017 \{published data only\}}

Riaz HM, Shakeel A, Shaheen MA, Jaa K. Efficacy of pimecrolimus cream and triamcinolone acetonide paste in the treatment of symptomatic oral lichen planus. Medical Forum 2017;28:76-80.

\section{Salazar-Sánchez 2010 \{published data only\}}

Salazar-Sánchez N, López-Jornet P, Camacho-Alonso F, Sánchez-Siles M. Efficacy of topical Aloe vera in patients with oral lichen planus: a randomized double-blind study. Journal of Oral Pathology \& Medicine 2010;39(10):735-40.

\section{Singh 2017 \{published data only\}}

Singh AR, Rai A, Aftab M, Jain S, Singh M. Efficacy of steroidal vs non-steroidal agents in oral lichen planus: a randomised, openlabel study. Journal of Laryngology and Otology 2017;131:69-76.

\section{Swift 2005 \{published data only\}}

Swift JC, Rees TD, Plemons JM, Hallmon WW, Wright JC. The effectiveness of $1 \%$ pimecrolimus cream in the treatment of oral erosive lichen planus. Journal of Periodontology 2005;76(4):627-35

\section{Tyldesley 1977 \{published data only\}}

Tyldesley WR, Harding SM. Betamethasone valerate aerosol in the treatment of oral lichen planus. British Journal of Dermatology 1977;96(6):659-62.

\section{Volz 2008 \{published data only\}}

Volz T, Caroli U, Ludtke H, Brautigam M, Kohler-Spath H, Rocken $\mathrm{M}$, et al. Pimecrolimus cream $1 \%$ in erosive oral lichen planus - a prospective randomized double-blind vehicle-controlled study. British Journal of Dermatology 2008;159(4):936-41.

\section{Wu 2010 \{published data only\}}

Wu Y, Zhou G, Zeng H, Xiong CR, Lin M, Zhou HM. A randomized double-blind, positive-control trial of topical thalidomide in erosive oral lichen planus. Oral Surgery, Oral Medicine, Oral Pathology, Oral Radiology, and Endodontics 2010;110(2):188-95.

\section{References to studies awaiting assessment}

\section{Fricain 2014 \{published and unpublished data\}}

Fricain JC, Boralevi F, Hüttenberger B, Sammini M, Vaillant L. Effectiveness of topical rapamycin in the treatment of lichen planus. Oral Diseases 2014;20(s2):16.

\section{Qu 2016 \{published data only\}}

Qu CH. Observation on the therapeutic effect of therapy of integrated medicine in the treatment of oral lichen planus. Chinese Medicine Modern Distance Education of China 2016;14(5):96-7.

\section{References to ongoing studies}

2017-002193-40 \{published data only\}

2017-002193-40. Clinical study in oral lichen planus (OLP) patients to assess how safe and effective the Rivelin ${ }^{\circledR}$-CLO patches are when applied in the mouth. www.clinicaltrialsregister.eu/ctr-search/search?query= \%222017-002193-40\%22 (first received 4 April 2018).

ChiCTR1800016507 \{published data only\}

ChiCTR1800016507. An evaluation on the short-term efficacy and safety of $0.01 \%$ compound betamethasone mouth rinse in treatment of oral erosion lichen planus: a randomized controlled clinical trial. chictr.org.cn/showproj.aspx?proj=28090 (first received 5 June 2018).

\section{CTRI/2018/03/012661 \{published data only\}}

CTRI/2018/03/012661. Use of curcumin (turmeric) in treatment of oral ulcers due to lichen planus. ctri.nic.in/Clinicaltrials/ pmaindet2.php?trialid=21106 (first received 19 March 2018).

\section{CTRI/2018/08/015185 \{published data only\}}

CTRI/2018/08/015185. Treatment for the local application of oral ulcers seen in oral lichen planus. ctri.nic.in/Clinicaltrials/ pmaindet2.php?trialid=19980 (first received 3 August 2018).

\section{CTRI/2018/08/015563 \{published data only\}}

CTRI/2018/08/015563. Evaluation of the effectiveness of neem extracts mouthwash as an adjuvant therapeutic modality in the management of oral lichen planus. ctri.nic.in/Clinicaltrials/ pmaindet2.php?trialid=26260 (first received 31 August 2018).

\section{Ferri 2018 \{published data only\}}

Ferri E, de Barros Gallo C, Saad Abboud C, Yanaguizawa WH, Ratto Tempestini Horliana AC, de Fatima Teixeira da Silva D, et al. Efficacy of photobiomodulation on oral lichen planus: a protocol study for a double-blind, randomised controlled clinical trial. BMJ Open 2018;8:e024083.

\section{IRCT20171017036835N2 \{published data only\}}

IRCT20171017036835N2. The effect of vitamin D on oral lichen planus. en.irct.ir/trial/27430 (first received 8 March 2018).

IRCT20181226042133N1 \{published data only\}

IRCT20181226042133N1. Comparison of therapeutic effect of mucoadhesive nano-triamcinolone gel and conventional triamcinolone gel on oral lichen planus. en.irct.ir/trial/36282 (first received 8 January 2019).

NCT03386643 \{published data only\}

NCT03386643. Effect of Bifidobacterium animals subsp. lactis HN019 on oral lichen planus. clinicaltrials.gov/ct2/show/ nct03386643 (first received 29 December 2017).

NCT03592342 \{published data only\}

NCT03592342. Intra-oral treatment of OLP With Rivelin ${ }^{\circledR}$-CLO Patche. clinicaltrials.gov/show/NCT03592342 (first received 19 July 2018). 


\section{NCT03738176 \{published data only\}}

NCT03738176. The efficacy of topical sesame oil versus topical triamcinolone on oral lichen planus and salivary level of oxidative stress biomarker. clinicaltrials.gov/show/ NCT03738176 (first received 13 November 2018).

\section{NCT03793634 \{published data only\}}

NCT03793634. Evaluation of topical chamomile versus topical triamcinolone acetonide in management of oral lichen planus. clinicaltrials.gov/show/NCT03793634 (first received 4 January 2019).

\section{Additional references}

\section{Aghbari 2017}

Aghbari SM, Abushouk Al, Attia A, Elmaraezy A, Menshawy A, Ahmed MS, et al. Malignant transformation of oral lichen planus and oral lichenoid lesions: a meta-analysis of 20095 patient data. Oral Oncology 2017;68:92-102.

\section{Ahluwalia 1998}

Ahluwalia A. Topical glucocorticoids and the skin - mechanisms of action: an update. Mediators of Inflammation 1998;7:183-93.

\section{Akram 2018}

Akram Z, Abduljabbar T, Vohra F, Javed F. Efficacy of low-level laser therapy compared to steroid therapy in the treatment of oral lichen planus: a systematic review. Journal of Oral Pathology \& Medicine 2018;47:11-7.

\section{Al-Hashimi 2007}

Al-Hashimi I, Schifter M, Lockhart PB, Wray D, Brennan M, Migliorati CA, et al. Oral lichen planus and oral lichenoid lesions: diagnostic and therapeutic considerations. Oral Surgery, Oral Medicine, Oral Pathology, Oral Radiology, and Endodontics 2007;103(Suppl 1):S25.e1-12.

\section{Al-Maweri 2018}

Al-Maweri SA, Ashraf S, Kalakonda B, Halboub E, Petro W, AlAizari NA. Efficacy of photodynamic therapy in the treatment of symptomatic oral lichen planus: a systematic review. Journal of Oral Pathology \& Medicine 2018;47(4):326-32.

\section{Ali 2017}

Ali S, Wahbi W. The efficacy of aloe vera in management of oral lichen planus: a systematic review and meta-analysis. Oral Diseases 2017:23:913-8.

\section{Alrashdan 2016}

Alrashdan MS, Cirillo N, McCullough M. Oral lichen planus: a literature review and update. Archives of Dermatological Research 2016;308:539-51.

\section{Atkins 2004}

Atkins D, Best D, Briss PA, Eccles M, Falck-Ytter Y, Flottorp S, et al. Grading quality of evidence and strength of recommendations. BMJ 2004;328:1490.

\section{Becker 2006}

Becker JC, Houben R, Vetter CS, Bröcker EB. The carcinogenic potential of tacrolimus ointment beyond immune suppression: a hypothesis creating case report. BMC Cancer 2006;6:7.

\section{Carrozzo 1999}

Carrozzo M, Gandolfo S. The management of oral lichen planus. Oral Diseases 1999;5(3):196-205.

\section{Carrozzo 2004}

Carrozzo M, Uboldi de Capei M, Dametto E, Fasano ME, Arduino P, Broccoletti R, et al. Tumor necrosis factor-alpha and interferon-gamma polymorphisms contribute to susceptibility to oral lichen planus. Journal of Investigative Dermatology 2004;122(1):87-94.

\section{Carrozzo 2009}

Carrozzo M, Thorpe R. Oral lichen planus: a review. Minerva Stomatologica 2009;58(10):519-37.

\section{Chamani 2015}

Chamani G, Rad M, Zarei MR, Lotfi S, Sadeghi M, Ahmadi Z. Efficacy of tacrolimus and clobetasol in the treatment of oral lichen planus: a systematic review and meta-analysis. International Journal of Dermatology 2015;54:996-1004.

\section{Cribier 1998}

Cribier B, Frances C, Chosidow O. Treatment of lichen planus. An evidence-based medicine analysis of efficacy. Archives of Dermatology 1998;134(12):1521-30.

\section{Eisen 2002}

Eisen D. The clinical features, malignant potential, and systemic associations of oral lichen planus: a study of 723 patients. Journal of the American Academy of Dermatology 2002;46(2):207-14.

\section{Eisen 2005}

Eisen D, Carrozzo M, Bagan Sebastian JV, Thongprasom K. Number $V$ Oral lichen planus: clinical features and management. Oral Diseases 2005;11(6):338-49.

\section{Gonzalez-Moles 2008}

Gonzalez-Moles MA, Scully C, Gil-Montoya JA. Oral lichen planus: controversies surrounding malignant transformation. Oral Diseases 2008;14(3):229-43.

\section{Higgins 2011}

Higgins JP, Green S, editor(s). Cochrane Handbook for Systematic Reviews of Interventions Version 5.1.0 (updated March 2011). The Cochrane Collaboration, 2011. Available from handbook.cochrane.org.

\section{Kazancioglu 2015}

Kazancioglu HO, Erisen M. Comparison of low-level laser therapy versus ozone therapy in the treatment of oral lichen planus. Annals of Dermatology 2015;27:485-91.

\section{Kramer 1978}

Kramer IR, Lucas RB, Pindborg JJ, Sobin LH. Definition of leukoplakia and related lesions: an aid to studies on oral 
precancer. Oral Surgery, Oral Medicine, and Oral Pathology 1978;46:518-39.

\section{Le Cleach 2012}

Le Cleach L, Chosidow O. Clinical practice. Lichen planus. New England Journal of Medicine 2012;366:723-32.

\section{Lefebvre 2011}

Lefebvre C, Manheimer E, Glanville J. Chapter 6: Searching for studies. In: Higgins JP, Green S, editor(s). Cochrane Handbook for Systematic Reviews of Interventions Version 5.1.0 (updated March 2011). The Cochrane Collaboration, 2011. Available from handbook.cochrane.org.

\section{Lodi 2005a}

Lodi G, Scully C, Carrozzo M, Griffiths M, Sugerman PB, Thongprasom K. Current controversies in oral lichen planus: report of an international consensus meeting. Part 1. Viral infections and etiopathogenesis. Oral Surgery, Oral Medicine, Oral Pathology, Oral Radiology, and Endodontics 2005;100(1):40-51.

\section{Lodi 2005b}

Lodi G, Scully C, Carrozzo M, Griffiths M, Sugerman PB, Thongprasom K. Current controversies in oral lichen planus: report of an international consensus meeting. Part 2. Clinical management and malignant transformation. Oral Surgery, Oral Medicine, Oral Pathology, Oral Radiology, and Endodontics 2005;100(2):164-78.

\section{Lodi 2010}

Lodi G, Pellicano R, Carrozzo M. Hepatitis C virus infection and lichen planus: a systematic review with meta-analysis. Oral Diseases 2010;16:601-12.

\section{López-Jornet 2010}

López-Jornet P, Camacho-Alonso F. Quality of life in patients with oral lichen planus. Journal of Evaluation in Clinical Practice 2010;16(1):111-3.

\section{Mattsson 2010}

Mattsson U, Magnusson B, Jontell M. Squamous cell carcinoma in a patient with oral lichen planus treated with topical application of tacrolimus. Oral Surgery, Oral Medicine, Oral Pathology, Oral Radiology, and Endodontics 2010;110(1):e19-25.

\section{Moher 2009}

Moher D, Liberati A, Tetzlaff J, Altman DG, The PRISMA Group. Preferred Reporting Items for Systematic Reviews and Meta-Analyses: the PRISMA statement. PLoS Medicine 2009;6(7):e1000097.

\section{Ní Ríordáin 2015}

Ní Ríordáin R, Shirlaw P, Alajbeg I, Al Zamel G, Fung L, Yuan AD, et al. World Workshop on Oral Medicine VI: patient-reported outcome measures and oral mucosal disease: current status and future direction. Oral Surgery, Oral Medicine, Oral Pathology, and Oral Radiology 2015;120:152-60.

\section{Schünemann 2017}

Schünemann HJ, Oxman AD, Higgins JP, Vist GE, Glasziou P, Akl $E$, et al. on behalf of the Cochrane GRADEing Methods Group and the Cochrane Statistical Methods Group. Chapter 11: Completing 'Summary of findings' tables and grading the confidence in or quality of the evidence. In: Higgins JP, Churchill R, Chandler J, Cumpston MS, editor(s), Cochrane Handbook for Systematic Reviews of Interventions version 5.2.0 (updated June 2017). The Cochrane Collaboration, 2017. Available from www.training.cochrane.org/handbook.

\section{Suresh 2016}

Suresh SS, Chokshi K, Desai S, Malu R, Chokshi A. Medical management of oral lichen planus: a systematic review. Journal of Clinical and Diagnostic Research 2016;10:ZE10-5.

\section{Tadakamadla 2015}

Tadakamadla J, Kumar S, Johnson NW. Quality of life in patients with oral potentially malignant disorders: a systematic review. Oral Surgery, Oral Medicine, Oral Pathology, and Oral Radiology 2015;119:644-55.

\section{Thomas 1997}

Thomas DW, Stephens P, Stephens M, Patten DW, Lim SH. T-cell receptor $\mathrm{V}$ beta usage by lesional lymphocytes in oral lichen planus. Journal of Oral Pathology and Medicine 1997;26:105-9.

\section{Thongprasom 1992}

Thongprasom K, Luangjarmekorn L, Sererat T, Taweesap W. Relative efficacy of fluocinolone acetonide compared with triamcinolone acetonide in treatment of oral lichen planus. Journal of Oral Pathology \& Medicine 1992;21(10):456-8.

\section{Van der Meij 2003}

Van der Meij EH, Van der Waal I. Lack of clinicopathologic correlation in the diagnosis of oral lichen planus based on the presently available diagnostic criteria and suggestions for modifications. Journal of Oral Pathology and Medicine 2003;32:507-12.

\section{Varoni 2012}

Varoni EM, Molteni A, Sardella A, Carrassi A, Di Candia D, Gigli F, et a. Pharmacokinetics study about topical clobetasol on oral mucosa. Journal of Oral Pathology \& Medicine 2012;41:255-60.

\section{Zegarelli 1960}

Zegarelli EV, Kutscher AH. Triamcinolone acetonide in the treatment of erosive lichen planus of the oral mucosae. Preliminary report. Archives of Dermatology 1960;82:1010-1.

\section{References to other published versions of this review Chan 1999}

Chan ES, Thornhill M, Zakrzewska JJ. Interventions for treating oral lichen planus. Cochrane Database of Systematic Reviews 1999, Issue 2. [DOI: 10.1002/14651858.CD001168] 


\section{Thongprasom 2011}

Thongprasom K, Carrozzo M, Furness S, Lodi G. Interventions

* Indicates the major publication for the study for treating oral lichen planus. Cochrane Database of Systematic Reviews 2011, Issue 7. [DOI: 10.1002/14651858.CD001168.pub2]

\section{CHARACTERISTICS OF STUDIES}

Characteristics of included studies [ordered by study ID]

Amanat 2014

Methods
Study design: split-mouth RCT
Conducted in Iran
Number of centres: 1
Recruitment period: July 2012 to January 2013
Funding source: supported by Vice Chancellory of Shiraz University of Medical Sciences (no. 90010342)
Inclusion criteria: bilateral clinically and biopsy confirmed OLP lesions (size $>4 \mathrm{~cm}$ ), similar in form bi-
laterally with < 1 cm difference in size
Exclusion criteria: systemic disease, pregnancy, drug consumption, smoking, people with lesions con-
tacting dental amalgam, and people with dermal and other mucosal involvement at the time of the
therapy. Participants did not receive any treatment for OLP at least 1 month prior to the beginning of
the study.
Randomised 30 participants; analysed 23 participants at final follow-up (split-mouth design)

Interventions Group A: triamcinolone acetonide ointment $0.1 \%$ in Orabase (3 times daily for 1 week, tapered to twice daily on week 2 , once daily on week 3 , alternate day on week 4 and discontinued at week 5 )

Group B: single session of cryotherapy with nitrous oxide gas

$\begin{array}{ll}\text { Outcomes } & \text { Pain score (VAS), Thongprasom sign score (based on size and appearance), improvement scale based } \\ \text { on } \mathrm{EI}(\mathrm{no} \text { improvement }(\mathrm{EI}=0) \text {, mild improvement ( } \mathrm{EI}>0 \text { to } 25 \%) \text {, moderate improvement }(\mathrm{EI} \geq 25 \% \text { to } \\ <75 \%) \text {, marked improvement }(\mathrm{EI} \geq 75 \% \text { to }<100 \%) \text { and healed }(\mathrm{EI}=100 \%)\end{array}$

Measured before treatment and after 2, 4 and 6 weeks of treatment

Notes

\section{Risk of bias}

\begin{tabular}{lll}
\hline Bias & Authors' judgement & Support for judgement \\
\hline $\begin{array}{l}\text { Random sequence genera- } \\
\text { tion (selection bias) }\end{array}$ & Unclear risk & Insufficient information to permit judgement. \\
\hline $\begin{array}{l}\text { Allocation concealment } \\
\text { (selection bias) }\end{array}$ & Unclear risk & Insufficient information to permit judgement. \\
\hline $\begin{array}{l}\text { Blinding of participants } \\
\begin{array}{l}\text { and personnel (perfor- } \\
\text { mance bias) } \\
\text { All outcomes }\end{array}\end{array}$ & High risk & Not feasible. \\
\hline
\end{tabular}

$\begin{array}{ll}\text { Blinding of outcome as- } & \text { High risk }\end{array}$


Amanat 2014 (Continued)

All outcomes

$\begin{array}{ll}\begin{array}{l}\text { Incomplete outcome data } \\ \text { (attrition bias) }\end{array} & \text { High risk } \\ \text { All outcomes } & \text { Quote: "Two patients chose to discontinue the study protocol after } 3 \text { weeks } \\ & \begin{array}{l}\text { and other treatments were begun. Two patients were also excluded on week } \\ 4 \text { due to poor compliance and wrong use of ointment. Three patients did not } \\ \text { come for the third follow-up session." }\end{array}\end{array}$

Selective reporting (re- Low risk Planned outcomes reported.

porting bias)

Other bias Low risk No other sources of bias identified.

Amirchaghmaghi 2016

\begin{tabular}{|c|c|c|}
\hline \multirow[t]{5}{*}{ Methods } & \multicolumn{2}{|l|}{ Study design: RCT } \\
\hline & \multicolumn{2}{|l|}{ Conducted in Iran } \\
\hline & \multicolumn{2}{|l|}{ Number of centres: 1} \\
\hline & \multicolumn{2}{|c|}{ Recruitment period: October 2012 to June 2013} \\
\hline & \multicolumn{2}{|c|}{ Funding source: supported by Vice Chancellory of Mashhadd University of Medical Sciences } \\
\hline \multirow[t]{4}{*}{ Participants } & \multicolumn{2}{|c|}{$\begin{array}{l}\text { Inclusion criteria: people with clinical signs of erosive-atrophic OLP which was confirmed by clinical } \\
\text { and histopathological examination }\end{array}$} \\
\hline & \multicolumn{2}{|c|}{$\begin{array}{l}\text { Exclusion criteria: pregnancy; breastfeeding; current use of anticoagulants or antiplatelet agents; cur- } \\
\text { rent orthodontic treatment; history of gastric ulcers, duodenal ulcers, gallstones, hepatic diseases, any } \\
\text { existing malignancy or viral infection in mouth; receiving any topical treatment for OLP in the past } 2 \\
\text { weeks or any systemic treatment for OLP in the past } 4 \text { weeks; use of azathioprine, ciclosporin or receiv- } \\
\text { ing PUVA, UVA or UVB in the last month; history of allergy to corticosteroids or curcumin }\end{array}$} \\
\hline & \multicolumn{2}{|c|}{ Group A: randomised 12; analysed 12} \\
\hline & \multicolumn{2}{|c|}{ Group B: randomised 8; analysed 8} \\
\hline \multirow[t]{2}{*}{ Interventions } & \multicolumn{2}{|c|}{$\begin{array}{l}\text { Group A: } 1 \text { dexamethasone mouthwash } 0.5 \mathrm{mg} 3 \text { times daily }+1 \text { nystatin }(100,000 \text { units) suspension } 3 \\
\text { times daily + } 4 \text { curcumin tablets }(500 \mathrm{mg}) \text { twice daily for } 4 \text { weeks }\end{array}$} \\
\hline & \multicolumn{2}{|c|}{$\begin{array}{l}\text { Group B: } 1 \text { dexamethasone mouthwash } 0.5 \mathrm{mg} 3 \text { times daily }+1 \text { nystatin }(100,000 \text { units }) \text { suspension } 3 \\
\text { times daily + } 4 \text { placebo tablets twice daily for } 4 \text { weeks }\end{array}$} \\
\hline \multirow[t]{2}{*}{ Outcomes } & \multicolumn{2}{|c|}{ Pain (VAS), clinical score (Thongprasom), complete resolution, adverse effects } \\
\hline & \multicolumn{2}{|c|}{ Measured at baseline, 14 days and 28 days } \\
\hline \multicolumn{3}{|l|}{ Notes } \\
\hline \multicolumn{3}{|l|}{ Risk of bias } \\
\hline Bias & Authors' judgement & Support for judgement \\
\hline $\begin{array}{l}\text { Random sequence genera- } \\
\text { tion (selection bias) }\end{array}$ & Low risk & $\begin{array}{l}\text { Quote: "Randomization was performed using a computer-generated random } \\
\text { number table." }\end{array}$ \\
\hline
\end{tabular}


Amirchaghmaghi 2016 (Continued)

Allocation concealment Low risk
(selection bias)

Quote: "Randomization was performed using a computer-generated random number table. Study medication tablets with $95 \%$ curcominoids (Samilabs Limited, Bangalore, India) and identical placebo tablets (containing lactose) were prepackaged by a university pharmacist in identical containers. During treatment, both of the practitioners and the patients were unaware of medications they were using."

\begin{tabular}{|c|c|c|}
\hline $\begin{array}{l}\text { Blinding of participants } \\
\text { and personnel (perfor- }\end{array}$ & Low risk & $\begin{array}{l}\text { Quote: "During treatment, both of [sic] the practitioners and the pa } \\
\text { unaware of medications they were using." }\end{array}$ \\
\hline
\end{tabular}

All outcomes

\begin{tabular}{|c|c|c|}
\hline $\begin{array}{l}\text { Blinding of outcome as- } \\
\text { sessment (detection bias) }\end{array}$ & Low risk & $\begin{array}{l}\text { Quote: "During treatment, both of [sic] the practitioners and the patients were } \\
\text { unaware of medications they were using." }\end{array}$ \\
\hline
\end{tabular}

\begin{tabular}{lll}
\hline $\begin{array}{l}\text { Incomplete outcome data } \\
\text { (attrition bias) } \\
\text { All outcomes }\end{array}$ & Low risk & $\begin{array}{l}\text { Comment: no missing data. All randomised participants included in the result } \\
\text { analysis. }\end{array}$ \\
\hline $\begin{array}{l}\text { Selective reporting (re- } \\
\text { porting bias) }\end{array}$ & Low risk & Planned outcomes reported. \\
\hline Other bias & Low risk & No other sources of bias identified. \\
\hline
\end{tabular}

Arduino 2018

Study design: RCT
Conducted in Italy
Number of centres: 1
Recruitment period: unspecified
Funding source: supported by the principal investigator's own funds

Participants Inclusion criteria: histological diagnosis of OLP, on the basis of WHO criteria (Kramer 1978), and presenting painful lesions

Exclusion criteria: occurrence dysplasia in the histopathological specimen; use of lichenoid reaction inducing medication and presence of amalgam fillings nearby the lesions; interventions for OLP in the previous 12 weeks; pregnant or breastfeeding women; confirmed or suspected hypersensitivity to any of the chemicals used in the treatment

Group A: randomised 18; analysed 16

Group B: randomised 18; analysed 16

Interventions Group A: clobetasol propionate $0.025 \%$ in $4 \%$ hydroxyethyl cellulose gel + miconazole gel once daily + $0.12 \%$ chlorhexidine mouthrinse twice daily for 8 weeks

Group B: hydroxyethyl cellulose twice daily + miconazole gel once daily $+0.12 \%$ chlorhexidine mouthrinse twice daily for 8 weeks

Outcomes Pain (VAS 0-10 cm), clinical score (Thongprasom), adverse effects

\section{Notes}


Arduino 2018 (Continued)

Risk of bias

\begin{tabular}{|c|c|c|}
\hline Bias & Authors' judgement & Support for judgement \\
\hline $\begin{array}{l}\text { Random sequence genera- } \\
\text { tion (selection bias) }\end{array}$ & Low risk & $\begin{array}{l}\text { Quote: "Computer-generated randomisation list (with blocked randomisation } \\
\text { of 4)." }\end{array}$ \\
\hline $\begin{array}{l}\text { Allocation concealment } \\
\text { (selection bias) }\end{array}$ & Low risk & $\begin{array}{l}\text { Quote: "Allocation concealment was ensured by keeping the randomisation } \\
\text { list in the care of one of the investigators not involved in the clinical part of the } \\
\text { study." }\end{array}$ \\
\hline $\begin{array}{l}\text { Blinding of participants } \\
\text { and personnel (perfor- } \\
\text { mance bias) } \\
\text { All outcomes }\end{array}$ & Low risk & $\begin{array}{l}\text { Quote: "During treatment, neither the principal investigator nor the involved } \\
\text { subjects knew which one of the two treatments they were using." }\end{array}$ \\
\hline $\begin{array}{l}\text { Blinding of outcome as- } \\
\text { sessment (detection bias) } \\
\text { All outcomes }\end{array}$ & Low risk & $\begin{array}{l}\text { Quote: "During treatment, neither the principal investigator nor the involved } \\
\text { subjects knew which one of the two treatments they were using." }\end{array}$ \\
\hline $\begin{array}{l}\text { Incomplete outcome data } \\
\text { (attrition bias) } \\
\text { All outcomes }\end{array}$ & Low risk & $\begin{array}{l}\text { Comment: missing data balanced in numbers across intervention groups ( } 2 \\
\text { and } 2 \text { ) and not likely to have a clinically relevant impact on the intervention ef- } \\
\text { fect estimate. Unlikely to have introduced bias. }\end{array}$ \\
\hline $\begin{array}{l}\text { Selective reporting (re- } \\
\text { porting bias) }\end{array}$ & Low risk & Planned outcomes reported. \\
\hline Other bias & Low risk & No other sources of bias identified. \\
\hline
\end{tabular}

Arunkumar 2015

$\begin{array}{ll}\text { Methods } & \text { Study design: RCT } \\ & \text { Conducted in India } \\ & \text { Number of centres: } 1 \\ & \text { Recruitment period: unspecified } \\ \text { Funding source: } \text { nil }\end{array}$

Participants Inclusion criteria: people with symptomatic OLP (pain or burning sensation, or both) who were agreeing for the biopsy and were ready to apply the medication supplied

Exclusion criteria: people with a history of malignancy, immunocompromised diseases, current systemic or generalised infections, pregnancy or breastfeeding, received topical or systemic immunosuppressants, retinoids or any other systemic therapies known to cause or suspected to have an effect on OLP within the last 4 weeks and allergic to the drugs supplied

Group A: randomised 15; analysed 15

Group B: randomised 15; analysed 15

Interventions Group A: triamcinolone acetonide $0.1 \%$ oral paste 4 times daily for 2 months

Group B: pimecrolimus $1 \%$ oral paste 4 times daily for 2 months 
Arunkumar 2015 (Continued)

Outcomes Pain (VAS), clinical score (Thongprasom), presence of erythematous areas

\section{Notes}

\section{Risk of bias}

\begin{tabular}{lll}
\hline Bias & Authors' judgement & Support for judgement \\
\hline $\begin{array}{l}\text { Random sequence genera- } \\
\text { tion (selection bias) }\end{array}$ & Unclear risk & Comment: insufficient information to permit judgement. \\
\hline $\begin{array}{l}\text { Allocation concealment } \\
\text { (selection bias) }\end{array}$ & Unclear risk & Comment: insufficient information to permit judgement. \\
\hline $\begin{array}{l}\text { Blinding of participants } \\
\text { and personnel (perfor- } \\
\text { mance bias) }\end{array}$ & Unclear risk & Comment: insufficient information to permit judgement. \\
All outcomes & & \\
\hline
\end{tabular}

Blinding of outcome as- Unclear risk Comment: insufficient information to permit judgement.

sessment (detection bias)

All outcomes

Incomplete outcome data Low risk Comment: no missing data. All randomised participants included in analysis.

(attrition bias)

All outcomes

\begin{tabular}{lll}
\hline $\begin{array}{l}\text { Selective reporting (re- } \\
\text { porting bias) }\end{array}$ & Low risk & Planned outcomes reported. \\
\hline Other bias & Low risk & No other sources of bias identified. \\
\hline
\end{tabular}

\section{Bakhtiari 2017}

\begin{tabular}{ll}
\hline Methods & Study design: RCT \\
Conducted in Iran \\
Number of centres: 1 \\
Recruitment period: unclear \\
Funding source: unspecified
\end{tabular}

\section{Participants}

Inclusion criteria: clinically and histopathologically diagnosed with reticular and erosive LP, seeking medical management

Exclusion criteria: presence of histological signs of dysplasia, use of drugs which caused lichenoid reactions, therapy for OLP in 2 months prior to the study, pregnant or breastfeeding women, uncontrolled systemic disease, lesions adjacent to amalgam fillings and people with photosensitivity

Group A: randomised 15; analysed 15

Group B: randomised 15; analysed 15

Interventions

Group A: dexamethasone mouthwash ( $0.5 \mathrm{mg}$ in $5 \mathrm{~mL}$ of water) 4 times daily +1 nystatin mouthwash 4 times daily for 2 weeks 
Bakhtiari 2017 (Continued)

Group B: methylene blue as photosensitiser and light source of LED $630 \mathrm{~nm}$ (Fotosan, Denmark). Device was used according to manufacturer's instructions. Output power was $7.2-14.4 \mathrm{~J} / \mathrm{cm}^{2}$ and probe diameter was $8 \mathrm{~mm}$. Participants gargled methylene blue $5 \%$ for 5 minutes and 10 minutes prior to irradiation. Each lesion was irradiated for 30 seconds up to 2 minutes with spot technique

\begin{tabular}{ll}
\hline Outcomes & Pain (VAS), clinical score (Thongprasom), clinical severity index, EI \\
& Measured at days $15,30,60$ and 90 after beginning of the treatment
\end{tabular}

Notes VAS results were reported graphically; data extraction was not possible

\section{Risk of bias}

\begin{tabular}{|c|c|c|}
\hline Bias & Authors' judgement & Support for judgement \\
\hline $\begin{array}{l}\text { Random sequence genera- } \\
\text { tion (selection bias) }\end{array}$ & Unclear risk & Comment: insufficient information to permit judgement. \\
\hline $\begin{array}{l}\text { Allocation concealment } \\
\text { (selection bias) }\end{array}$ & Unclear risk & Comment: insufficient information to permit judgement. \\
\hline $\begin{array}{l}\text { Blinding of participants } \\
\text { and personnel (perfor- } \\
\text { mance bias) } \\
\text { All outcomes }\end{array}$ & High risk & Comment: blinding not feasible. \\
\hline $\begin{array}{l}\text { Blinding of outcome as- } \\
\text { sessment (detection bias) } \\
\text { All outcomes }\end{array}$ & High risk & $\begin{array}{l}\text { Comment: participants (self-assessed, pain was primary outcome) were not } \\
\text { blinded. }\end{array}$ \\
\hline $\begin{array}{l}\text { Incomplete outcome data } \\
\text { (attrition bias) } \\
\text { All outcomes }\end{array}$ & Low risk & Comment: no missing data. All randomised participants included in analysis. \\
\hline $\begin{array}{l}\text { Selective reporting (re- } \\
\text { porting bias) }\end{array}$ & High risk & $\begin{array}{l}\text { Comment: } \geq 1 \text { outcomes of interest were reported incompletely (standard de- } \\
\text { viations were missing) so data could not be entered in a meta-analysis. }\end{array}$ \\
\hline Other bias & Low risk & No other sources of bias identified. \\
\hline
\end{tabular}

Campisi 2004

\begin{tabular}{ll}
\hline Methods & Study design: RCT \\
Conducted in Italy & Number of centres: 1 \\
& Recruitment period: unclear \\
& Funding source: unspecified \\
\hline Participants & $\begin{array}{l}\text { OLP; naive status (no previous treatment for OLP in last } 6 \text { months); willingness (written informed con- } \\
\text { sent) and ability to complete the trial }\end{array}$ \\
& $\begin{array}{l}\text { Exclusion criteria: histological presence of dysplasia; use of drugs associated with lichenoid reactions; } \\
\text { contemporary skin or genital lesions (or both), pregnancy, immunodysfunction and haematological } \\
\text { disease }\end{array}$
\end{tabular}



application daily for the second month

Group B: clobetasol propionate $0.025 \%$ in a dispersion of a lipophilic ointment in a hydrophilic phase, 2 applications daily for the first month and 1 application daily for the second month

Outcomes Pain (VAS), clinical score (Thongprasom), adverse effects

\section{Notes}

\section{Risk of bias}

\begin{tabular}{|c|c|c|}
\hline Bias & Authors' judgement & Support for judgement \\
\hline $\begin{array}{l}\text { Random sequence genera- } \\
\text { tion (selection bias) }\end{array}$ & Unclear risk & Comment: insufficient information to permit judgement. \\
\hline $\begin{array}{l}\text { Allocation concealment } \\
\text { (selection bias) }\end{array}$ & Unclear risk & Comment: insufficient information to permit judgement. \\
\hline $\begin{array}{l}\text { Blinding of participants } \\
\text { and personnel (perfor- } \\
\text { mance bias) } \\
\text { All outcomes }\end{array}$ & High risk & Not feasible. \\
\hline $\begin{array}{l}\text { Blinding of outcome as- } \\
\text { sessment (detection bias) } \\
\text { All outcomes }\end{array}$ & High risk & $\begin{array}{l}\text { Comment: participants (self-assessed, pain was primary outcome) were not } \\
\text { blinded. }\end{array}$ \\
\hline $\begin{array}{l}\text { Incomplete outcome data } \\
\text { (attrition bias) } \\
\text { All outcomes }\end{array}$ & Low risk & $\begin{array}{l}\text { Comment: missing data balanced in numbers across intervention groups ( } 2 \\
\text { and } 3 \text { ) and unlikely to have a clinically relevant impact on the intervention ef- } \\
\text { fect estimate. Unlikely to have introduced bias. }\end{array}$ \\
\hline $\begin{array}{l}\text { Selective reporting (re- } \\
\text { porting bias) }\end{array}$ & Low risk & Planned outcomes reported. \\
\hline Other bias & Low risk & No other sources of bias identified. \\
\hline
\end{tabular}

\section{Carbone 2009}

\begin{tabular}{ll}
\hline Methods & Study design: RCT \\
Conducted in Italy & Number of centres: 1 \\
& Recruitment period: $2005-2006$ \\
& Funding source: unspecified \\
\hline Participants & $\begin{array}{l}\text { Inclusion criteria: histological diagnosis of OLP on the basis of WHO criteria; hyperkeratosis of the su- } \\
\text { perficial epithelial layers, vacuolar degeneration of the germinative layer of the epithelium and band- } \\
\text { like subepithelial lymphocytic inflammatory infiltrate; presence of painful and atrophic-erosive oral le- } \\
\text { sions, at the same time with reticular ones; ability to complete the present clinical trial }\end{array}$ \\
\hline
\end{tabular}


Exclusion criteria: presence of histological signs of dysplasia; use of lichenoid reaction-inducing drugs; presence of amalgam fillings close to lesions; therapy for OLP in 6 months prior to study; skin, genital or other extraoral lesions; pregnant or breastfeeding women; confirmed or suspected hypersensitivity caused by the tested chemicals

Group A: randomised 18; analysed 15

Group B: randomised 17; analysed 15

Group A: clobetasol priopionate $0.025 \%$ in $4 \%$ hydroxyethyl cellulose gel, 2 applications daily for 2
months
Group B: clobetasol priopionate $0.05 \%$ in $4 \%$ hydroxyethyl cellulose gel, 2 applications daily for 2
months

Outcomes

Pain (VAS), clinical score (Thongprasom), relapses, adverse effects

\section{Notes}

\section{Risk of bias}

\begin{tabular}{|c|c|c|}
\hline Bias & Authors' judgement & Support for judgement \\
\hline $\begin{array}{l}\text { Random sequence genera- } \\
\text { tion (selection bias) }\end{array}$ & Low risk & Quote: "computer generated random number tables." \\
\hline $\begin{array}{l}\text { Allocation concealment } \\
\text { (selection bias) }\end{array}$ & Low risk & $\begin{array}{l}\text { Quote: "the medication, packed by a pharmacist, was distributed in indistin- } \\
\text { guishable containers." }\end{array}$ \\
\hline $\begin{array}{l}\text { Blinding of participants } \\
\text { and personnel (perfor- } \\
\text { mance bias) } \\
\text { All outcomes }\end{array}$ & Low risk & Quote: "Double blind." \\
\hline $\begin{array}{l}\text { Blinding of outcome as- } \\
\text { sessment (detection bias) } \\
\text { All outcomes }\end{array}$ & Low risk & Quote: "Double blind." \\
\hline $\begin{array}{l}\text { Incomplete outcome data } \\
\text { (attrition bias) } \\
\text { All outcomes }\end{array}$ & Low risk & $\begin{array}{l}\text { Comment: missing data balanced in numbers across intervention groups ( } 3 \\
\text { and } 2 \text { ) and not likely to have a clinically relevant impact on the intervention ef- } \\
\text { fect estimate. Unlikely to have introduced bias. }\end{array}$ \\
\hline $\begin{array}{l}\text { Selective reporting (re- } \\
\text { porting bias) }\end{array}$ & Low risk & Planned outcomes reported. \\
\hline Other bias & Low risk & No other sources of bias identified. \\
\hline
\end{tabular}

\section{Chainani-Wu 2007}

Study design: RCT
Conducted in USA
Number of centres: 1
Recruitment period: February 2003 to August 2004 (then stopped for futility following an interim analy-
sis)


Chainani-Wu 2007 (Continued)

Funding source: Mount Zion Health Fund, through UCSF

Participants Inclusion criteria: aged $>21$ years, with a current presentation of atrophic or erosive OLP, and a symptom score for OLP between 3 and 8 at enrolment. All participants had been diagnosed by clinical as well as histopathological examination of oral lesions.

Exclusion criteria: pregnancy; breastfeeding; medical contraindication to prednisone or fluconazole; on long-term corticosteroid therapy; current use of anticoagulants or antiplatelet agents; current orthodontic treatment; history of gastric ulcers, duodenal ulcers, gallstones or liver disease

Group A: randomised 17; analysed 17 (ITT analysis)

Group B: randomised 16; analysed 16 (ITT analysis)

\begin{tabular}{|c|c|}
\hline Interventions & $\begin{array}{l}\text { Group A: prednisone } 60 \mathrm{mg}+\text { curcuminoids } 2000 \mathrm{mg} \text { daily (in } 2 \text { divided doses) for } 7 \text { weeks } \\
\text { Group B: prednisone } 60 \mathrm{mg}+\text { placebo daily (in } 2 \text { divided doses) for } 7 \text { weeks }\end{array}$ \\
\hline Outcomes & Pain (VAS), clinical score (modified Oral Mucositis Index), change in symptoms scale, adverse effects \\
\hline Notes & $\begin{array}{l}\text { Among participants who completed the study, all participants in the placebo group had }>85 \% \text { compli- } \\
\text { ance, and } 14 \text { had }>95 \% \text { compliance (range } 87.7-100 \% \text { ); in the curcuminoids group, all but } 1 \text { had }>95 \% \\
\text { compliance (range } 64.2-100 \% \text { ). }\end{array}$ \\
\hline & $\begin{array}{l}\text { Comment: after enrolling } 33 \text { participants, the study was halted for futility following an interim analysis. } \\
\text { Estimated post hoc power to detect a difference was } 7 \% \text {. }\end{array}$ \\
\hline
\end{tabular}

\section{Risk of bias}

\begin{tabular}{|c|c|c|}
\hline Bias & Authors' judgement & Support for judgement \\
\hline $\begin{array}{l}\text { Random sequence genera- } \\
\text { tion (selection bias) }\end{array}$ & Low risk & $\begin{array}{l}\text { Quote: "The randomisation sequence was generated [...] using random num- } \\
\text { ber generator." }\end{array}$ \\
\hline $\begin{array}{l}\text { Allocation concealment } \\
\text { (selection bias) }\end{array}$ & Unclear risk & Comment: insufficient information to permit judgement. \\
\hline $\begin{array}{l}\text { Blinding of participants } \\
\text { and personnel (perfor- } \\
\text { mance bias) } \\
\text { All outcomes }\end{array}$ & Low risk & Quote: "Both patients and investigators were blind." \\
\hline $\begin{array}{l}\text { Blinding of outcome as- } \\
\text { sessment (detection bias) } \\
\text { All outcomes }\end{array}$ & Low risk & Quote: "Both patients and investigators were blind." \\
\hline $\begin{array}{l}\text { Incomplete outcome data } \\
\text { (attrition bias) } \\
\text { All outcomes }\end{array}$ & Low risk & ITT analysis. 5/33 (15\%) participants lost at follow-up, unbalanced (4 and 1). \\
\hline $\begin{array}{l}\text { Selective reporting (re- } \\
\text { porting bias) }\end{array}$ & High risk & $\begin{array}{l}\text { Comment: } \geq 1 \text { outcomes of interest were reported incompletely (standard de- } \\
\text { viations were missing) so they could not be entered in a meta-analysis. }\end{array}$ \\
\hline Other bias & Low risk & $\begin{array}{l}5 \text { participants used topical corticosteroids during the study. Of these, } 2 \text { were in } \\
\text { the placebo group and } 3 \text { were in the curcuminoids group ( } 1 \text { of whom dropped } \\
\text { out of the study after } 4 \text { weeks, at the second follow-up visit). Unlikely to have } \\
\text { caused bias. }\end{array}$ \\
\hline
\end{tabular}


Conrotto 2006

\begin{tabular}{|c|c|}
\hline \multirow[t]{5}{*}{ Methods } & Study design: RCT \\
\hline & Conducted in Italy \\
\hline & Number of centres: 1 \\
\hline & Recruitment period: $1999-2002$ \\
\hline & Funding source: company provided drugs \\
\hline \multirow[t]{4}{*}{ Participants } & Inclusion criteria: clinical and histological OLP; painful lesions \\
\hline & $\begin{array}{l}\text { Exclusion criteria: presence of histological signs of dysplasia; use of lichenoid reaction-inducing drugs; } \\
\text { presence of amalgam fillings close to lesions; therapy for OLP in the } 6 \text { months prior to the study; skin, } \\
\text { genital or other extraoral lesions; pregnant or breastfeeding women }\end{array}$ \\
\hline & Group A: randomised 20; analysed 19 \\
\hline & Group B: randomised 20; analysed 20 \\
\hline \multirow[t]{2}{*}{ Interventions } & Group A: clobetasol propionate $0.025 \%$ in $4 \%$ hydroxyethyl cellulose gel, twice daily for 2 months \\
\hline & Group B: ciclosporin $1.5 \%$ in $4 \%$ hydroxyethyl cellulose gel, twice daily for 2 months \\
\hline Outcomes & Pain resolution, clinical score (Thongprasom), adverse effects, cost \\
\hline
\end{tabular}

\section{Risk of bias}

\begin{tabular}{|c|c|c|}
\hline Bias & Authors' judgement & Support for judgement \\
\hline $\begin{array}{l}\text { Random sequence genera- } \\
\text { tion (selection bias) }\end{array}$ & Low risk & Quote: "computer-generated random number tables." \\
\hline $\begin{array}{l}\text { Allocation concealment } \\
\text { (selection bias) }\end{array}$ & Low risk & $\begin{array}{l}\text { Authors implied that the allocation list was hidden and allocation performed } \\
\text { by pharmacy. }\end{array}$ \\
\hline $\begin{array}{l}\text { Blinding of participants } \\
\text { and personnel (perfor- } \\
\text { mance bias) } \\
\text { All outcomes }\end{array}$ & Unclear risk & $\begin{array}{l}\text { Quote: "double blind"; however, ciclosporine has a distinct foul taste so as- } \\
\text { sessed as 'unclear' }\end{array}$ \\
\hline $\begin{array}{l}\text { Blinding of outcome as- } \\
\text { sessment (detection bias) } \\
\text { All outcomes }\end{array}$ & Low risk & Quote: "double blind." \\
\hline $\begin{array}{l}\text { Incomplete outcome data } \\
\text { (attrition bias) } \\
\text { All outcomes }\end{array}$ & Low risk & $\begin{array}{l}\text { Comment: missing data not likely to have a clinically relevant impact on the in- } \\
\text { tervention effect estimate ( } 1 \text { participant from Group A). Unlikely to have intro- } \\
\text { duced bias. }\end{array}$ \\
\hline $\begin{array}{l}\text { Selective reporting (re- } \\
\text { porting bias) }\end{array}$ & Low risk & Planned outcomes reported. \\
\hline Other bias & Low risk & No other sources of bias identified. \\
\hline
\end{tabular}


Corrocher 2008

\begin{tabular}{ll}
\hline Methods & Study design: RCT \\
Conducted in Italy & Number of centres: 1 \\
& Recruitment period: unclear \\
& Funding source: unspecified \\
\hline Inclusion criteria: aged > 18 years; moderate-to-severe OLP; clinical and histological diagnosis \\
Exclusion criteria: presence of skin or genital lesions (or both); histopathological signs of dysplasia; \\
treatment with drugs that may have induced lichenoid reactions; treatment with systemic corticos- \\
teroids, immunosuppressant therapy, topical glucocorticoids or tacrolimus within the previous 8 \\
weeks; chronic liver disease; immune system dysfunction; haematological disease; pregnancy; breast- \\
feeding \\
Group A: randomised 16; analysed 16 \\
Group B: randomised 16; analysed 16
\end{tabular}

Interventions

Group A: tacrolimus $0.1 \%$ ointment $2 \mathrm{~mL} 4$ times daily for 4 weeks

Group B: clobetasol $0.05 \%$ ointment $2 \mathrm{~mL} 4$ times daily for 4 weeks

Outcomes Pain (4-grade scale: absent, mild, moderate, severe), clinical score (4-grade scale: absent, mild, moderate, severe), adverse effects

\section{Notes}

\section{Risk of bias}

\begin{tabular}{|c|c|c|}
\hline Bias & Authors' judgement & Support for judgement \\
\hline $\begin{array}{l}\text { Random sequence genera- } \\
\text { tion (selection bias) }\end{array}$ & Low risk & Quote: "Computer randomisation." \\
\hline $\begin{array}{l}\text { Allocation concealment } \\
\text { (selection bias) }\end{array}$ & Unclear risk & Comment: insufficient information to permit judgement. \\
\hline $\begin{array}{l}\text { Blinding of participants } \\
\text { and personnel (perfor- } \\
\text { mance bias) } \\
\text { All outcomes }\end{array}$ & Low risk & Quote: "Double blind." \\
\hline $\begin{array}{l}\text { Blinding of outcome as- } \\
\text { sessment (detection bias) } \\
\text { All outcomes }\end{array}$ & Low risk & Quote: "Double blind." \\
\hline $\begin{array}{l}\text { Incomplete outcome data } \\
\text { (attrition bias) } \\
\text { All outcomes }\end{array}$ & Low risk & $\begin{array}{l}\text { Comment: no missing data. All randomised participants included in the result } \\
\text { analysis. }\end{array}$ \\
\hline $\begin{array}{l}\text { Selective reporting (re- } \\
\text { porting bias) }\end{array}$ & Low risk & Planned outcomes reported. \\
\hline Other bias & Low risk & No other sources of bias identified. \\
\hline
\end{tabular}


Dillenburg 2014

\begin{tabular}{ll}
\hline Methods & Study design: RCT \\
Conducted in Brazil \\
Number of centres: 1 \\
Recruitment period: February 2012 to November 2012 \\
Funding source: supported by Postgraduate Research Group of Porto Alegre University Hospital \\
Inclusion criteria: aged > 21 years, symptomatic atrophic/erosive OLP, histopathological diagnosis of \\
OLP based on WHO-based criteria \\
Exclusion criteria: pregnancy or nursing women, histological signs of dysplasia, OLP therapy in the pre- \\
vious 3 months, amalgam restorations near the lesions and the use of medications associated with oral \\
lichenoid reactions \\
Group A: randomised 21; analysed 16 \\
Group B: randomised 21; analysed 17
\end{tabular}

Interventions Group A: clobetasol propionate gel $0.05 \% 3$ times daily for 4 weeks and nystatin 100,000 UI/mL oral rinses 3 times daily

Group B: InGaAIP laser applications, 3 times weekly for 4 weeks (12 sessions) and nystatin 100,000 UI/ $\mathrm{mL}$ oral rinses 3 times daily

Outcomes Pain (VAS), clinical score (Thongrasom), functional score (Lilleby score - 5 grades), relapse rate, anxiety questionnaire (Beck Anxiety Inventory), adverse effects

Measured once weekly during treatment (days 7, 14, 21 and 30) and 4 weeks (day 60) and 8 weeks (day 90) after treatment

\section{Notes}

\section{Risk of bias}

\begin{tabular}{|c|c|c|}
\hline Bias & Authors' judgement & Support for judgement \\
\hline $\begin{array}{l}\text { Random sequence genera- } \\
\text { tion (selection bias) }\end{array}$ & Low risk & $\begin{array}{l}\text { Quote: "The patients were randomly assigned to one of the two treatment } \\
\text { groups using computer-generated random number tables." }\end{array}$ \\
\hline $\begin{array}{l}\text { Allocation concealment } \\
\text { (selection bias) }\end{array}$ & Unclear risk & Comment: insufficient information to permit judgement. \\
\hline $\begin{array}{l}\text { Blinding of participants } \\
\text { and personnel (perfor- } \\
\text { mance bias) } \\
\text { All outcomes }\end{array}$ & High risk & Quote: "The patient was not blinded to the treatment." \\
\hline $\begin{array}{l}\text { Blinding of outcome as- } \\
\text { sessment (detection bias) } \\
\text { All outcomes }\end{array}$ & High risk & $\begin{array}{l}\text { Comment: participants (self-assessed, pain was primary outcome) were not } \\
\text { blinded. }\end{array}$ \\
\hline $\begin{array}{l}\text { Incomplete outcome data } \\
\text { (attrition bias) } \\
\text { All outcomes }\end{array}$ & High risk & $\begin{array}{l}5 / 21(23.8 \%) \text { participants from Group A and } 4 / 21 \text { (19\%) from Group B were lost } \\
\text { at follow-up. }\end{array}$ \\
\hline
\end{tabular}


Dillenburg 2014 (Continued)

$\begin{array}{ll}\begin{array}{l}\text { Selective reporting (re- } \\ \text { porting bias) }\end{array} & \text { High risk } \\ \end{array}$

Other bias Low risk No other sources of bias identified.

\section{Ezzatt 2019}

Study design: RCT
Conducted in Egypt
Number of centres: 2 (Department of Oral Medicine, Oral Diagnosis and Periodontology, Faculty of Den-
tistry and the Department of Skin and Venereal Diseases, Faculty of Medicine in Ain Shams Universi-
ty-Egypt)
Recruitment period: unspecified
Funding source: supported by the principal investigator's own funds

\begin{tabular}{|c|c|}
\hline \multirow[t]{4}{*}{ Participants } & $\begin{array}{l}\text { Inclusion criteria: systemically free, both genders aged } 25-60 \text { years, clinically and histologically con- } \\
\text { firmed painful erosive or atrophic OLP according to modified WHO criteria }\end{array}$ \\
\hline & $\begin{array}{l}\text { Exclusion criteria: history of drug-induced lichenoid lesions, potential treatment of OLP for }<2 \text { weeks } \\
\text { by topical and } 4 \text { weeks systemic therapy before study, pregnancy, breastfeeding, smoking and known } \\
\text { hypersensitivity or severe adverse effects to the treatment drugs or to any ingredient of their prepara- } \\
\text { tion }\end{array}$ \\
\hline & Group A: randomised 15; analysed 15 \\
\hline & Group B: randomised 15; analysed 15 \\
\hline
\end{tabular}

Interventions

Group A: betamethasone 17 -valerate $0.1 \%$ adhesive gel base, 4 times daily for 4 weeks

Group B: pimecrolimus adhesive $1 \%$ gel base, 4 times daily for 4 weeks

\begin{tabular}{ll}
\hline Outcomes & Pain (VAS), clinical score (5-grade scale), adverse effects \\
\hline Notes & All the outcomes were reported in a way that allowed us to perform quantitative analysis.
\end{tabular}

\section{Risk of bias}

\begin{tabular}{|c|c|c|}
\hline Bias & Authors' judgement & Support for judgement \\
\hline $\begin{array}{l}\text { Random sequence genera- } \\
\text { tion (selection bias) }\end{array}$ & Low risk & Quote: "computer-generated randomization assignment (blocks of 4)." \\
\hline $\begin{array}{l}\text { Allocation concealment } \\
\text { (selection bias) }\end{array}$ & Low risk & $\begin{array}{l}\text { Quote: "Allocation concealment was performed by sealed envelopes contain- } \\
\text { ing the randomization number." }\end{array}$ \\
\hline $\begin{array}{l}\text { Blinding of participants } \\
\text { and personnel (perfor- } \\
\text { mance bias) } \\
\text { All outcomes }\end{array}$ & Low risk & $\begin{array}{l}\text { Quote: "both patients and outcome assessors were blinded for the type of } \\
\text { medication." }\end{array}$ \\
\hline $\begin{array}{l}\text { Blinding of outcome as- } \\
\text { sessment (detection bias) } \\
\text { All outcomes }\end{array}$ & Low risk & $\begin{array}{l}\text { Quote: "both patients and outcome assessors were blinded for the type of } \\
\text { medication." }\end{array}$ \\
\hline
\end{tabular}


Ezzatt 2019 (Continued)

Incomplete outcome data Low risk Comment: no missing data. All randomised participants included in the result (attrition bias) analysis.

All outcomes

Selective reporting (re- Low risk Planned outcomes reported.

porting bias)

Other bias Low risk No other sources of bias identified.

Fu 2012

Study design: RCT
Conducted in West China
Number of centres: 1 (Department of Oral Medicine, School of Stomatology, Sichuan University)
Recruitment period: September 2009 to December 2009
Funding source: unspecified

Participants Inclusion criteria: histopathologically and clinically diagnosed with erosive OLP; presence of a single erosion lesion; aged from 18 to approximately 70 years; erosive area not exceeding $1.5 \mathrm{~cm}^{2}$; and normal physical examination results before medication (including complete blood cell count, renal and hepatic clinical chemistry examination, urine and stool routine test, blood pressure examination, ultrasonic examination of abdomen, chest x-ray and electrocardiogram).

Exclusion criteria: presence of severe systemic diseases or other severe oral mucous diseases; use of antibiotics within 1 month or immunomodulating drugs within 3 months; history of topical treatment within 1 week; presence of lichenoid reaction caused by amalgam fillings or certain drugs (including beta-blockers, dapsone, oral hypoglycaemics, non-steroidal anti-inflammatory drugs, penicillamine, phenothiazines, sulphonylureas and gold salts); pregnancy, intention of pregnancy, breastfeeding or recent use of steroid hormone-based contraceptives; history of psychiatric disorders; participation in any other clinical trials in the 3 months before enrolment in study; refusing to follow medical advice; or could not finish the return visits

Group A: randomised 20; analysed 19

Group B: randomised 18; analysed 17

Interventions

Group A: amlexanox paste $250 \mathrm{mg}, 3$ times daily for 1 week

Group B: dexamethasone paste $6.45 \mathrm{mg}$ (0.043\%), 3 times daily for 1 week

Outcomes Pain (VAS), size of erosive area, adverse effects

Notes

\section{Risk of bias}

Bias Authors' judgement Support for judgement

Random sequence genera- Low risk tion (selection bias)

Quote: "The patients were assigned to the experimental group or positive-control group by using a computer generated random number list."

Allocation concealment Unclear risk Comment: insufficient information to permit judgement.

(selection bias) 


\section{Fu 2012 (Continued)}

Blinding of participants Unclear risk Comment: the trial authors reported that the containers were the same, but and personnel (performance bias)

All outcomes no details were reported about blinding of personnel or the assessor, so we

judged the study as unclear.

\section{Blinding of outcome as- Unclear risk sessment (detection bias) \\ Comment: the trial authors reported that the containers were the same, but All outcomes no details were reported about blinding of personnel or assessor, so we judged the study as unclear.}

Incomplete outcome data Low risk (attrition bias)

All outcomes
Comment: missing data balanced in numbers across intervention groups (1 and 1 ) and not likely to have a clinically relevant impact on the intervention effect estimate. Unlikely to have introduced bias.

Selective reporting (re- Low risk $\quad$ Planned outcomes reported.
porting bias)

Other bias Low risk No other sources of bias identified.

Ghabanchi 2009

\begin{tabular}{|c|c|}
\hline \multirow[t]{4}{*}{ Methods } & Study design: RCT \\
\hline & Conducted in Iran \\
\hline & Number of centres: 1 \\
\hline & Recruitment period: unclear \\
\hline \multirow[t]{3}{*}{ Participants } & Inclusion criteria: not specified \\
\hline & Exclusion criteria: not specified \\
\hline & Group A: randomised 9; analysed 9 \\
\hline \multirow[t]{2}{*}{ Interventions } & Group A: prednisolone 5 mg mucoadhesive tablet, twice daily for 2 weeks \\
\hline & Group B: triamcinolone acetonide $0.1 \%$ paste, 3 times daily for 2 weeks \\
\hline \multirow[t]{2}{*}{ Outcomes } & Clinical score (5-grade score), adverse effects \\
\hline & $\begin{array}{l}\text { Quote: "Every variable (pain, atrophy, ulceration and interference in daily life) was evaluated indepen- } \\
\text { dently by the same experienced clinician at 2-6 follow ups (the first one } 48 \text { hours after the beginning of } \\
\text { treatment)." }\end{array}$ \\
\hline
\end{tabular}

Notes

\section{Risk of bias}

\begin{tabular}{lll}
\hline Bias & Authors' judgement & Support for judgement \\
\hline $\begin{array}{l}\text { Random sequence genera- } \\
\text { tion (selection bias) }\end{array}$ & Unclear risk & Comment: insufficient information to permit judgement. \\
\hline
\end{tabular}


Ghabanchi 2009 (Continued)

$\begin{aligned} & \text { Allocation concealment Unclear risk } \\ & \text { (selection bias) }\end{aligned}$ Comment: insufficient information to permit judgement.

\begin{tabular}{|c|c|c|}
\hline $\begin{array}{l}\text { Blinding of participants } \\
\text { and personnel (perfor- } \\
\text { mance bias) } \\
\text { All outcomes }\end{array}$ & High risk & Not feasible. \\
\hline $\begin{array}{l}\text { Blinding of outcome as- } \\
\text { sessment (detection bias) } \\
\text { All outcomes }\end{array}$ & High risk & Not feasible. \\
\hline $\begin{array}{l}\text { Incomplete outcome data } \\
\text { (attrition bias) } \\
\text { All outcomes }\end{array}$ & Low risk & $\begin{array}{l}\text { Comment: no missing data. All randomised participants included in result } \\
\text { analysis. }\end{array}$ \\
\hline $\begin{array}{l}\text { Selective reporting (re- } \\
\text { porting bias) }\end{array}$ & High risk & $\begin{array}{l}\text { Comment: } \geq 1 \text { outcomes of interest were reported incompletely (standard de- } \\
\text { viations were missing) so they could not be entered in a meta-analysis. Data } \\
\text { on adverse effects were not reported clearly (quote: "many patients dislike the } \\
\text { bitter taste of topical prednisolone mucoadhesive tablet"). }\end{array}$ \\
\hline Other bias & Low risk & No other sources of bias identified. \\
\hline
\end{tabular}

\section{Gorouhi 2007}

$\begin{array}{ll}\text { Methods } & \text { Study design: RCT } \\ \text { Conducted in Iran } \\ \text { Number of centres: } 1 \\ \text { Recruitment period: May } 2005 \text { to January } 2006 \\ \text { Funding source: company provided drugs }\end{array}$

Participants Inclusion criteria: people with histopathologically confirmed OLP, aged $>8$ years

Exclusion criteria: malignant or viral involvement in the mouth; had received topical therapy for OLP in the last 2 weeks or systemic therapy in the last 4 weeks; used azathioprine, ciclosporin, psoralen $+\mathrm{ul}-$ traviolet (UV) A, UVA, or UVB in the last month; or had a history of allergy to either immunomodulators or corticosteroids

Group A: randomised 20; analysed 18

Group B: randomised 20; analysed 17

Interventions $\quad$ Group A: pimecrolimus $1 \%$ cream, 4 times daily for 2 months
Group B: triamcinolone acetonide $0.1 \%$ paste, 4 times daily for 2 months

Outcomes

Pain (VAS), clinical score (Thongprasom), quality of life (OHIP), adverse effects

Treatment lasted 2 months and follow-up for a further 2 months

\section{Notes}

\section{Risk of bias}


Gorouhi 2007 (Continued)

\section{Bias Authors' judgement Support for judgement}

Random sequence genera- Low risk Quote: "randomization sequence was generated by use of a randomization tation (selection bias) ble."

Allocation concealment Low risk Quote: "randomization numbers in sealed envelopes."

(selection bias)

Blinding of participants High risk Quote: "single blind" (assessor).
and personnel (perfor-
mance bias)
All outcomes

\begin{tabular}{lll}
\hline $\begin{array}{l}\text { Blinding of outcome as- } \\
\text { sessment (detection bias) }\end{array}$ & High risk & $\begin{array}{l}\text { Comment: participants (self-assessed, pain was primary outcome) were not } \\
\text { blinded. }\end{array}$ \\
All outcomes &
\end{tabular}

\begin{tabular}{lll}
\hline $\begin{array}{l}\text { Incomplete outcome data } \\
\text { (attrition bias) } \\
\text { All outcomes }\end{array}$ & Low risk & ITT analysis. 5/40 (12.5\%) participants lost at follow-up, balanced (2 and 3). \\
\hline $\begin{array}{l}\text { Selective reporting (re- } \\
\text { porting bias) }\end{array}$ & Low risk & Planned outcomes reported. \\
\hline Other bias & Low risk & No other sources of bias identified. \\
\hline
\end{tabular}

Hashem 2019

\begin{tabular}{|c|c|}
\hline \multirow[t]{5}{*}{ Methods } & $\begin{array}{l}\text { Study design: RCT (trials authors incorrectly described their study as an "observational prospective } \\
\text { study") }\end{array}$ \\
\hline & Conducted in Egypt \\
\hline & Number of centres: 1 \\
\hline & Recruitment period: June to December 2017 \\
\hline & Funding source: unspecified \\
\hline \multirow[t]{4}{*}{ Participants } & $\begin{array}{l}\text { Inclusion criteria: any age or sex who had symptomatic OLP (including mixed forms), not related to any } \\
\text { identifiable cause (e.g. lichenoid drug reactions), and confirmed by histopathology }\end{array}$ \\
\hline & $\begin{array}{l}\text { Exclusion criteria: people undergoing systemic chemotherapy, people who were immunosuppressed or } \\
\text { had malignant diseases, pregnant women, and history of hypersensitivity to hyaluronic acid }\end{array}$ \\
\hline & Group A: randomised 20; analysed 20 \\
\hline & Group B: randomised 20; analysed 20 \\
\hline \multirow[t]{2}{*}{ Interventions } & Group A: triamcinolone preparation $0.1 \%, 3$ times daily for 28 days \\
\hline & Group B: hyaluronic acid preparation $0.2 \%, 3$ times daily for 28 days \\
\hline Outcomes & Pain (VAS), clinical score (modified oral mucositis index), size of erosive areas \\
\hline Notes & \\
\hline
\end{tabular}


Hashem 2019 (Continued)

Risk of bias

\begin{tabular}{|c|c|c|}
\hline Bias & Authors' judgement & Support for judgement \\
\hline $\begin{array}{l}\text { Random sequence genera- } \\
\text { tion (selection bias) }\end{array}$ & Unclear risk & Comment: insufficient information to permit judgement. \\
\hline $\begin{array}{l}\text { Allocation concealment } \\
\text { (selection bias) }\end{array}$ & Unclear risk & Comment: insufficient information to permit judgement. \\
\hline $\begin{array}{l}\text { Blinding of participants } \\
\text { and personnel (perfor- } \\
\text { mance bias) } \\
\text { All outcomes }\end{array}$ & Unclear risk & Comment: insufficient information to permit judgement. \\
\hline $\begin{array}{l}\text { Blinding of outcome as- } \\
\text { sessment (detection bias) } \\
\text { All outcomes }\end{array}$ & Unclear risk & Comment: insufficient information to permit judgement. \\
\hline $\begin{array}{l}\text { Incomplete outcome data } \\
\text { (attrition bias) } \\
\text { All outcomes }\end{array}$ & Low risk & $\begin{array}{l}\text { Comment: no missing data. All randomised participants included in the result } \\
\text { analysis. }\end{array}$ \\
\hline $\begin{array}{l}\text { Selective reporting (re- } \\
\text { porting bias) }\end{array}$ & Low risk & Planned outcomes reported. \\
\hline Other bias & Low risk & No other sources of bias identified. \\
\hline
\end{tabular}

Hegarty 2002

$\begin{array}{ll}\text { Methods } & \text { Study design: 2-arm cross-over RCT } \\ \text { Conducted in UK } \\ \text { Number of centres: } 1 \\ \text { Recruitment period: unclear } \\ \text { Funding source: unspecified }\end{array}$

\begin{tabular}{|c|c|}
\hline \multirow[t]{4}{*}{ Participants } & $\begin{array}{l}\text { Inclusion criteria: symptomatic erosive or ulcerative OLP, had not previously used fluticasone or be- } \\
\text { tamethasone, and were generally healthy }\end{array}$ \\
\hline & Exclusion criteria: unclear \\
\hline & Group A: randomised 22; analysed 19 \\
\hline & Group B: randomised 22; analysed 20 \\
\hline \multirow[t]{4}{*}{ Interventions } & $\begin{array}{l}\text { Fluticasone } 50 \mu \mathrm{g} \text { spray, } 2 \text { puffs applied to lesions } 4 \text { times daily, for } 6 \text { weeks and betamethasone sodi- } \\
\text { um phosphate } 500 \mu \mathrm{g}(0.5 \mathrm{mg} \text { in } 10 \mathrm{~mL} \text { of water), } 3 \text { minutes mouthrinse } 4 \text { times daily for } 6 \text { weeks }\end{array}$ \\
\hline & Group A: sequence fluticasone and betamethasone \\
\hline & Group B: sequence betamethasone and fluticasone \\
\hline & Washout period: 2 weeks \\
\hline
\end{tabular}


Hegarty 2002 (Continued)

Outcomes
Pain (VAS), clinical score (modified from Thongprasom), size of affected mucosa, quality of life (OHIP, $\mathrm{OHQOL})$, adverse effects

Notes

All 5 people who left the study ( 3 in group A and 2 in group B) did so during fluticasone treatment because of adverse effects.

\section{Risk of bias}

\begin{tabular}{|c|c|c|}
\hline Bias & Authors' judgement & Support for judgement \\
\hline $\begin{array}{l}\text { Random sequence genera- } \\
\text { tion (selection bias) }\end{array}$ & Low risk & Quote: "A table of random numbers was used." \\
\hline $\begin{array}{l}\text { Allocation concealment } \\
\text { (selection bias) }\end{array}$ & Low risk & $\begin{array}{l}\text { Quote: "The sequence was concealed until the effect of both intervention was } \\
\text { analysed." }\end{array}$ \\
\hline $\begin{array}{l}\text { Blinding of participants } \\
\text { and personnel (perfor- } \\
\text { mance bias) } \\
\text { All outcomes }\end{array}$ & High risk & Not feasible. \\
\hline $\begin{array}{l}\text { Blinding of outcome as- } \\
\text { sessment (detection bias) } \\
\text { All outcomes }\end{array}$ & High risk & Not feasible. \\
\hline $\begin{array}{l}\text { Incomplete outcome data } \\
\text { (attrition bias) } \\
\text { All outcomes }\end{array}$ & Low risk & $\begin{array}{l}\text { Comment: missing data balanced in numbers across intervention groups ( } 3 \\
\text { and } 2 \text { ) and not likely to have a clinically relevant impact on the intervention ef- } \\
\text { fect estimate. Unlikely to have introduced bias. }\end{array}$ \\
\hline $\begin{array}{l}\text { Selective reporting (re- } \\
\text { porting bias) }\end{array}$ & Low risk & $\begin{array}{l}\text { Planned outcomes reported. } \\
\text { Comment: data from this cross-over study were not analysed as paired and, } \\
\text { therefore, they could not be entered in a meta-analysis. }\end{array}$ \\
\hline Other bias & Low risk & No other sources of bias identified. \\
\hline
\end{tabular}

\section{Hesen 2017}

\begin{tabular}{ll}
\hline Methods & Study design: 3-arm RCT \\
& Conducted in Egypt \\
& Number of centres: 2 \\
& Recruitment period: unclear \\
& Funding source: unspecified \\
\hline Inclusion criteria: both sexes, aged 25-60 years, with clinically and histologically confirmed erosive/at- \\
rophic OLP and free from any systemic disease \\
Exclusion criteria: people with history of drug-induced lichenoid lesions or potential treatment for OLP \\
(for <2 weeks by topical or 4 weeks by systemic therapy) before start of study; pregnant or breastfeed- \\
ing women; smokers; known hypersensitivity or adverse effects to treatment drugs; losses of pliability \\
or flexibility in tissues involved by oral lesions or histological signs of epithelial dysplasia or lichenoid \\
lesions \\
Group A: randomised 10; analysed 10
\end{tabular}


Hesen 2017 (Continued)

Group B: randomised 10; analysed 10

Group C: randomised 10; analysed 10

\begin{tabular}{ll} 
Interventions & $\begin{array}{l}\text { Group A: topical triamcinolone acetonide } 0.1 \% \text { oral paste (GEO ORALOG; Geopharma, Cairo, Egypt) } 4 \\
\text { times daily + glucosamine sulphate } 500 \text { mg capsules orally } 3 \text { times daily (glucosamine; GlaxoSmithK- } \\
\text { line, Cairo, Egypt) for } 8 \text { weeks }\end{array}$ \\
$\begin{array}{l}\text { Group B: topical triamcinolone acetonide } 0.1 \% \text { oral paste twice daily + glucosamine sulphate } 500 \text { mg } 3 \\
\text { times daily for } 8 \text { weeks } \\
\text { Group C: topical triamcinolone acetonide } 0.1 \% \text { oral paste alone } 4 \text { times daily for } 8 \text { weeks }\end{array}$ \\
\hline Outcomes & Pain (VAS, resolution), clinical score (Thongprasom Classification score) \\
Measured at baseline, $1,2,4,6,8$ and 12 weeks \\
We compared the outcomes of Group A and Group C as the triamcinolone daily dose was the same (4 \\
times daily).
\end{tabular}

\section{Risk of bias}

\begin{tabular}{|c|c|c|}
\hline Bias & Authors' judgement & Support for judgement \\
\hline $\begin{array}{l}\text { Random sequence genera- } \\
\text { tion (selection bias) }\end{array}$ & Low risk & $\begin{array}{l}\text { Quote: "Patients were randomised into three groups (10 patients each) using } \\
\text { computer-generated randomisation assignment." }\end{array}$ \\
\hline $\begin{array}{l}\text { Allocation concealment } \\
\text { (selection bias) }\end{array}$ & Low risk & Quote: "allocation concealment with sealed envelopes." \\
\hline $\begin{array}{l}\text { Blinding of participants } \\
\text { and personnel (perfor- } \\
\text { mance bias) } \\
\text { All outcomes }\end{array}$ & Unclear risk & Comment: insufficient information to permit judgement. \\
\hline $\begin{array}{l}\text { Blinding of outcome as- } \\
\text { sessment (detection bias) } \\
\text { All outcomes }\end{array}$ & High risk & $\begin{array}{l}\text { Comment: participants (self-assessed, pain was primary outcome) were not } \\
\text { blinded. }\end{array}$ \\
\hline $\begin{array}{l}\text { Incomplete outcome data } \\
\text { (attrition bias) } \\
\text { All outcomes }\end{array}$ & Low risk & $\begin{array}{l}\text { Comment: no missing data. All randomised participants included in result } \\
\text { analysis. }\end{array}$ \\
\hline $\begin{array}{l}\text { Selective reporting (re- } \\
\text { porting bias) }\end{array}$ & High risk & Adverse effects, mentioned in the Methods were not reported in the Results. \\
\hline Other bias & Low risk & No other sources of bias identified. \\
\hline
\end{tabular}

Hettiarachchi 2017

$\begin{array}{ll}\text { Methods } & \text { Study design: RCT } \\ \text { Conducted in Sri Lanka } \\ \text { Number of centres: } 1 \text { (Oral Medicine Clinic, University Dental Hospital, Peradeniya, Sri Lanka) } \\ \text { Recruitment period: June } 2014 \text { to July } 2015 \\ \text { Funding source: University Research Grant RG/2013/08/D }\end{array}$


Hettiarachchi 2017 (Continued)

Participants

Inclusion criteria: histologically confirmed symptomatic OLP with main involvement of the bilateral buccal mucosae

Exclusion criteria: taken any topical or systemic medication for OLP in the previous 3 months; contraindication for use of medications, including history of allergy to either corticosteroids or tacrolimus; history suggestive of immunosuppression; history of developing possible lichenoid reactions either drug induced or due to dental amalgam; or pregnant or breastfeeding; people with diabetes taking oral hypoglycaemic drugs and people with concurrent skin/genital LP lesions.

Group A: randomised 34; analysed 34

Group B: randomised 34; analysed 34

$\begin{array}{ll}\text { Interventions } & \text { Group A: clobetasol } 0.05 \% \text { cream, twice daily for } 3 \text { weeks } \\ \text { Group B: tacrolimus } 0.1 \% \text { cream, twice daily for } 3 \text { weeks }\end{array}$

Outcomes Pain (VAS, resolution), clinical score (Thongprasom Classification score), adverse effects

Measured at baseline and 3 weeks

Notes

Pain and clinical score were recorded separately for right and left mucosal surfaces. As pooling was not feasible, we decided to randomly select 1 side only (right)

\section{Risk of bias}

\begin{tabular}{|c|c|c|}
\hline Bias & Authors' judgement & Support for judgement \\
\hline $\begin{array}{l}\text { Random sequence genera- } \\
\text { tion (selection bias) }\end{array}$ & Low risk & $\begin{array}{l}\text { Quote: "The randomisation sequence for patients was sourced using comput- } \\
\text { er-generated numbers." }\end{array}$ \\
\hline $\begin{array}{l}\text { Allocation concealment } \\
\text { (selection bias) }\end{array}$ & Low risk & $\begin{array}{l}\text { Quote: "that were sent in sealed envelopes to a trained nurse who was respon- } \\
\text { sible for giving the assigned treatment drug to each patient." }\end{array}$ \\
\hline $\begin{array}{l}\text { Blinding of participants } \\
\text { and personnel (perfor- } \\
\text { mance bias) } \\
\text { All outcomes }\end{array}$ & Low risk & $\begin{array}{l}\text { Quote: "Medications were identically prepackaged to maintain examiner and } \\
\text { patient blinding." }\end{array}$ \\
\hline $\begin{array}{l}\text { Blinding of outcome as- } \\
\text { sessment (detection bias) } \\
\text { All outcomes }\end{array}$ & Low risk & $\begin{array}{l}\text { Quote: "Medications were identically prepackaged to maintain examiner and } \\
\text { patient blinding." }\end{array}$ \\
\hline $\begin{array}{l}\text { Incomplete outcome data } \\
\text { (attrition bias) } \\
\text { All outcomes }\end{array}$ & Low risk & No missing data. All randomised participants included in analysis. \\
\hline $\begin{array}{l}\text { Selective reporting (re- } \\
\text { porting bias) }\end{array}$ & Low risk & Planned outcomes reported. \\
\hline Other bias & Low risk & No other sources of bias identified. \\
\hline
\end{tabular}

Kia 2015

$\begin{array}{ll}\text { Methods } & \text { Study design: RCT } \\ & \text { Conducted in Iran, Guilian University of Medical Sciences }\end{array}$


Kia 2015 (Continued)

Number of centres: 1

Recruitment period: 2 months

Funding source: unspecified

Participants Inclusion criteria: clinical signs of OLP (atrophic and ulcerative forms), confirmed by clinical and
histopathological examination

Exclusion criteria: pregnancy and breastfeeding; current use of anticoagulants or antiplatelet agents; current orthodontic treatment; history of gastric ulcers, duodenal ulcers, gallstones, hepatic diseases, any existing malignancy or viral infections in the mouth; history of topical treatment for OLP in the preceding 2 weeks or any systemic treatment for OLP in the preceding 4 weeks; taking azathioprine, ciclosporin or receiving Psoralen + ultraviolet A, ultraviolet A or ultraviolet B radiation in the past month; history of allergy to corticosteroids or curcumin

Group A: randomised 25; analysed 25

Group B: randomised 25; analysed 25

\begin{tabular}{ll} 
Interventions & Group A: curcumin paste $5 \%, 3$ times daily for 4 weeks \\
& Group B: triamcinolone acetonide paste $0.1 \%, 3$ times daily for 4 weeks \\
\hline Outcomes & $\begin{array}{l}\text { Complete remission (100\% reduction of signs and symptoms), pain (VAS), clinical response (Thongpra- } \\
\text { som Classification score) } \\
\text { Appearance score and severity of pain assessed at baseline and at end of } 2 \text { and } 4 \text { weeks }\end{array}$ \\
\hline Notes & $\begin{array}{l}\text { Trial registered in an unspecified register with code number IRCT2001105012950N2 } \\
\text { of the report they stated that the trial enrolled } 50 \text { participants and that all of them were included in the } \\
\text { analysis. }\end{array}$
\end{tabular}

\section{Risk of bias}

\begin{tabular}{|c|c|c|}
\hline Bias & Authors' judgement & Support for judgement \\
\hline $\begin{array}{l}\text { Random sequence genera- } \\
\text { tion (selection bias) }\end{array}$ & Low risk & $\begin{array}{l}\text { Quote: "The sample size of } 25 \text { was chosen based on expected and actual enrol- } \\
\text { ment of study subjects over a two-month time period. A blocked randomisa- } \\
\text { tion (block size of six) was used. The pharmacy of Guilan University of Medical } \\
\text { Sciences (...) generated the randomisation sequence using the random num- } \\
\text { ber generator in Microsoft Excel (Microsoft Corp, Seattle, WA)." }\end{array}$ \\
\hline $\begin{array}{l}\text { Allocation concealment } \\
\text { (selection bias) }\end{array}$ & Unclear risk & Insufficient information to permit judgement. \\
\hline $\begin{array}{l}\text { Blinding of participants } \\
\text { and personnel (perfor- } \\
\text { mance bias) } \\
\text { All outcomes }\end{array}$ & Unclear risk & $\begin{array}{l}\text { Quote: "Both participants and investigators were blinded to the treatment as- } \\
\text { signment." However, one intervention is yellow and the other white, so we as- } \\
\text { sessed this as unclear. }\end{array}$ \\
\hline $\begin{array}{l}\text { Blinding of outcome as- } \\
\text { sessment (detection bias) } \\
\text { All outcomes }\end{array}$ & Low risk & $\begin{array}{l}\text { Quote: "Both participants and investigators were blinded to the treatment as- } \\
\text { signment." }\end{array}$ \\
\hline $\begin{array}{l}\text { Incomplete outcome data } \\
\text { (attrition bias) } \\
\text { All outcomes }\end{array}$ & Low risk & No missing data. All randomised participants included in result analysis. \\
\hline
\end{tabular}


Kia 2015 (Continued)
Selective reporting (re-
Low risk
Planned outcomes reported. porting bias)

Other bias

Low risk

No other sources of bias identified.

Laeijendecker 2006

\begin{tabular}{ll}
\hline Methods & Study design: RCT \\
Conducted in Netherlands \\
Number of centres: 1 \\
Recruitment period: $2001-2004$ \\
Funding source: unspecified
\end{tabular}

Participants

Inclusion criteria: Caucasian people with a confirmed diagnosis of symptomatic OLP based on clinical and histopathological features

Exclusion criteria: aged < 18 years; histopathological examination with atypical or lichenoid dysplastic features; asymptomatic oral lesions and specific treatment within 4 weeks prior to the study

Group A: randomised 20; analysed 20

Group B: randomised 20; analysed 20

Interventions $\quad$ Group A: tacrolimus $0.1 \%$ ointment, 4 times daily for 6 weeks
Group B: triamcinolone acetonide $0.1 \%$ in hypromellose $20 \%$ ointment, 4 times daily for 6 weeks

Outcomes Clinical score (4-grade score), adverse effects

Notes

Risk of bias

\begin{tabular}{lll}
\hline Bias & Authors' judgement & Support for judgement \\
\hline $\begin{array}{l}\text { Random sequence genera- } \\
\text { tion (selection bias) }\end{array}$ & Low risk & Quote: "pre-determined randomisation list stratified by sex." \\
\hline $\begin{array}{l}\text { Allocation concealment } \\
\text { (selection bias) }\end{array}$ & Unclear risk & Comment: insufficient information to permit judgement. \\
\hline $\begin{array}{l}\text { Blinding of participants } \\
\text { and personnel (perfor- } \\
\text { mance bias) } \\
\text { All outcomes }\end{array}$ & Unclear risk & Comment: insufficient information to permit judgement. \\
\hline $\begin{array}{l}\text { Blinding of outcome as- } \\
\text { sessment (detection bias) } \\
\text { All outcomes }\end{array}$ & Unclear risk & Comment: insufficient information to permit judgement. \\
\hline $\begin{array}{l}\text { Incomplete outcome data } \\
\text { (attrition bias) } \\
\begin{array}{l}\text { All outcomes } \\
\hline\end{array}\end{array}$ & Low risk & Comment: no missing data. All randomised participants included in analysis. \\
\hline
\end{tabular}


Laeijendecker 2006 (Continued)

Selective reporting (re- Low risk Planned outcomes reported. porting bias)

Other bias Low risk No other sources of bias identified.

Liu 2013

$\begin{array}{ll}\text { Methods } & \text { Study design: RCT } \\ \text { Conducted in West China } \\ \text { Number of centres: } 1 \text { (Hospital of Stomatology, Sichuan University) } \\ \text { Recruitment period: April } 2011 \text { to May } 2012 \\ \text { Funding source: unspecified }\end{array}$

Participants

Inclusion criteria: erosive OLP determined clinically and pathologically, aged 18-60 years; single erosive lesion; erosive area $100 \mathrm{~mm}^{2}$; disease process duration < 2 months; normal physical examination results before medication (including complete blood cell count, blood glucose test, renal and hepatic clinical chemistry examination, blood pressure examination, ultrasonic examination of abdomen, chest $\mathrm{x}$-ray and electrocardiogram)

Exclusion criteria: > 1 site of erosion (e.g. people with bilateral erosions); hypertension (stage 2), cardiovascular disease, blood disease, or other systemic diseases; other oral mucosal diseases; immunotherapy within 3 months or other topical or systemic treatment of OLP within 1 week of the start of the study; lichenoid reaction caused by amalgam fillings or certain drugs; pregnancy or intention of pregnancy; breastfeeding; use of steroid hormone-based contraceptives recently; refusal to follow the doctor's advice or to complete the follow-up review

Group A: randomised 30; analysed 29

Group B: randomised 31; analysed 30

Interventions

Group A: betamethasone compound $1.4 \mathrm{mg}$ (betamethasone dipropionate $5 \mathrm{mg}$ + betamethasone disodium phosphate $2 \mathrm{mg} / \mathrm{mL}$ ), intralesional injection, once weekly for 2 weeks

Group B: triamcinolone acetonide $8 \mathrm{mg}$, intralesional injection, once weekly for 2 weeks

\section{Risk of bias}

\begin{tabular}{lll}
\hline Bias & Authors' judgement & Support for judgement \\
\hline $\begin{array}{l}\text { Random sequence genera- } \\
\text { tion (selection bias) }\end{array}$ & Low risk & $\begin{array}{l}\text { Quote: "Participants were assigned randomly to the experimental and control } \\
\text { groups using a computer-generated random number list." }\end{array}$ \\
\hline $\begin{array}{l}\text { Allocation concealment } \\
\text { (selection bias) }\end{array}$ & Unclear risk & Comment: insufficient information to permit judgement. \\
\hline $\begin{array}{l}\text { Blinding of participants } \\
\begin{array}{l}\text { and personnel (perfor- } \\
\text { mance bias) }\end{array}\end{array}$ & High risk & $\begin{array}{l}\text { Quote: "All injections were performed by the same researcher, who was the } \\
\text { only researcher aware of which participants received which medication." }\end{array}$ \\
\hline
\end{tabular}


Liu 2013 (Continued)

$\begin{array}{ll}\begin{array}{l}\text { Blinding of outcome as- } \\ \text { sessment (detection bias) }\end{array} \quad \text { High risk } & \begin{array}{l}\text { Comment: participants (self-assessed, pain was primary outcome) were not } \\ \text { blinded. }\end{array}\end{array}$
All outcomes blinded.

\begin{tabular}{|c|c|c|}
\hline $\begin{array}{l}\text { Incomplete outcome data } \\
\text { (attrition bias) } \\
\text { All outcomes }\end{array}$ & Low risk & $\begin{array}{l}\text { Comment: missing data balanced in numbers across intervention groups ( } 1 \text { in } \\
\text { each) and not likely to have a clinically relevant impact on the intervention ef- } \\
\text { fect estimate. Unlikely to have introduced bias. }\end{array}$ \\
\hline
\end{tabular}

\begin{tabular}{lll}
\hline $\begin{array}{l}\text { Selective reporting (re- } \\
\text { porting bias) }\end{array}$ & Low risk & Planned outcomes reported. \\
\hline Other bias & Low risk & No other sources of bias identified. \\
\hline
\end{tabular}

Lodi 2007

\begin{tabular}{|c|c|}
\hline \multirow[t]{5}{*}{ Methods } & Study design: RCT \\
\hline & Conducted in Italy \\
\hline & Number of centres: 1 \\
\hline & Recruitment period: May 2002 to January 2003 \\
\hline & Funding source: University of Milan \\
\hline \multirow[t]{4}{*}{ Participants } & $\begin{array}{l}\text { Inclusion criteria: clinical and histological diagnosis of OLP; symptomatic form of the disease; aged > } 18 \\
\text { years }\end{array}$ \\
\hline & $\begin{array}{l}\text { Exclusion criteria: previous treatment for OLP; systemic or local treatment with antifungal or corticos- } \\
\text { teroids in the } 6 \text { months prior to study; hypersensitivity to clobetasol propionate or miconazole; or un- } \\
\text { controlled diabetes or hypertension, systemic conditions that could hamper participation and compli- } \\
\text { ance with the study }\end{array}$ \\
\hline & Group A: randomised 18; analysed 15 \\
\hline & Group B: randomised 17; analysed 15 \\
\hline \multirow[t]{2}{*}{ Interventions } & Group A: clobetasol propionate gel $0.05 \%$ (twice daily) and miconazole $2 \%$ gel (once daily) for 6 weeks \\
\hline & Group B: clobetasol propionate gel $0.05 \%$ (twice daily) and placebo gel (once daily) for 6 weeks \\
\hline Outcomes & Pain (VAS), percentage of mucosa affected, adverse effects \\
\hline
\end{tabular}

\section{Risk of bias}

\begin{tabular}{lll}
\hline Bias & Authors' judgement & Support for judgement \\
\hline $\begin{array}{l}\text { Random sequence genera- } \\
\text { tion (selection bias) }\end{array}$ & Low risk & Quote: "allocation sequence was generated using software available online." \\
\hline $\begin{array}{l}\text { Allocation concealment } \\
\text { (selection bias) }\end{array}$ & Low risk & $\begin{array}{l}\text { Quote: "sequence was hidden from the researchers determining patient eligi- } \\
\text { bility." }\end{array}$ \\
\hline $\begin{array}{l}\text { Blinding of participants } \\
\begin{array}{l}\text { and personnel (perfor- } \\
\text { mance bias) }\end{array}\end{array}$ & Low risk & $\begin{array}{l}\text { Quote: "Neither the patient nor the clinician was aware of the content of the } \\
\text { syringes." }\end{array}$ \\
\hline
\end{tabular}


Lodi 2007 (Continued)

All outcomes

\begin{tabular}{|c|c|c|}
\hline $\begin{array}{l}\text { Blinding of outcome as- } \\
\text { sessment (detection bias) } \\
\text { All outcomes }\end{array}$ & Low risk & $\begin{array}{l}\text { Quote: "Neither the patient nor the clinician was aware of the content of the } \\
\text { syringes." }\end{array}$ \\
\hline $\begin{array}{l}\text { Incomplete outcome data } \\
\text { (attrition bias) } \\
\text { All outcomes }\end{array}$ & Low risk & $\begin{array}{l}\text { Comment: missing data balanced in numbers across intervention groups ( } 3 \\
\text { and } 2 \text { ) and not likely to have a clinically relevant impact on the intervention ef- } \\
\text { fect estimate. Unlikely to have introduced bias. }\end{array}$ \\
\hline $\begin{array}{l}\text { Selective reporting (re- } \\
\text { porting bias) }\end{array}$ & Low risk & Planned outcomes reported. \\
\hline Other bias & Low risk & No other sources of bias identified. \\
\hline
\end{tabular}

\section{Malhotra 2008}

\begin{tabular}{ll}
\hline Methods & Study design: RCT \\
Conducted in India \\
Number of centres: 1 \\
Recruitment period: January 2003 to March 2004 \\
Funding source: unspecified
\end{tabular}

\section{Participants}

Inclusion criteria: participants had either exclusive oral involvement or predominant oral involvement with few skin lesions, and had not received any treatment in the previous 4 weeks.

Exclusion criteria: children (aged < 15 years); elderly people (aged $>65$ years); pregnant and breastfeeding women; people with asymptomatic OLP; multiple or extensive skin lesions of LP; uncontrolled diabetes mellitus, or hypertension

Group A: randomised 25; analysed 23

Group B: randomised 24; analysed 23

Group A: betamethasone $5 \mathrm{mg}$ as single daily dose orally on 2 consecutive days every week (3 months), then $4 \mathrm{mg}$ (1 month), then $3 \mathrm{mg}$ ( 1 month), then $2 \mathrm{mg}$ (1 month)

Group B: triamcinolone acetonide $0.1 \%$ oral paste, 3 times daily during the first 3 months, followed by twice daily application in the 4th month, once daily application in the 5th month, and alternate day application during the 6 th month

Outcomes Pain (VAS), clinical score (semi-quantitative scoring system), adverse effects

\section{Notes}

\section{Risk of bias}

\begin{tabular}{lll}
\hline Bias & Authors' judgement & Support for judgement \\
\hline $\begin{array}{l}\text { Random sequence genera- } \\
\text { tion (selection bias) }\end{array}$ & Low risk & Quote: "generated from random table." \\
\hline $\begin{array}{l}\text { Allocation concealment } \\
\text { (selection bias) }\end{array}$ & Low risk & Quote: "patients were allocated using sealed envelope method." \\
\hline \hline
\end{tabular}


Malhotra 2008 (Continued)

Blinding of participants High risk Quote: "The study was not blinded." and personnel (performance bias)

All outcomes

\begin{tabular}{lll}
\hline Blinding of outcome as- & High risk $\quad$ Quote: "The study was not blinded." \\
sessment (detection bias) &
\end{tabular}

All outcomes

Incomplete outcome data Low risk

ITT analysis. $3 / 49$ (6\%) participants lost at follow-up, balanced ( 2 and 1 ).

(attrition bias)

All outcomes

\begin{tabular}{|c|c|c|}
\hline $\begin{array}{l}\text { Selective reporting (re- } \\
\text { porting bias) }\end{array}$ & High risk & $\begin{array}{l}\text { Comment: } \geq 1 \text { outcomes of interest were reported incompletely (standard de } \\
\text { viations were missing) so they could not be entered in a meta-analysis. }\end{array}$ \\
\hline
\end{tabular}

\begin{tabular}{ll}
\hline Other bias $\quad$ High risk & $\begin{array}{l}\text { The } 2 \text { groups showed statistically significant difference in clinical score at } \\
\text { baseline. }\end{array}$
\end{tabular}
baseline.

Mostafa 2017

$\begin{array}{ll}\text { Methods } & \text { Study design: RCT } \\ \text { Conducted in: Egypt } & \text { Number of centres: } 1 \\ \text { Recruitment period: unclear } \\ \text { Funding source: unspecified }\end{array}$

Inclusion criteria: oral erosive lesions were diagnosed according to Andreason classification; histologi-
cal confirmation of OLP according to the WHO's clinicopathological diagnostic criteria for OLP; no pre-
vious treatment of OLP for $\geq 3$ months; willingness and ability to complete the present clinical trial;
aged > 35 years without skin involvement
Exclusion criteria: histological signs of dysplasia; using drugs associated with lichenoid reaction; preg-
nant or breastfeeding; smoker; systemic diseases such as immunodysfunction, haematological and he-
patological; had photosensitivity history
Group A: randomised 10; analysed 10
Group B: randomised 10; analysed 10

Interventions

Group A: triamcinolone acetonide $0.1 \%$ in Orabase (Kenacort) 3 times daily for 6 weeks

Group B: photodynamic therapy mediated by methylene blue once weekly for 2 months

Outcomes Pain (VAS), clinical score (Thongprasom)

Notes

\section{Risk of bias}


Mostafa 2017 (Continued)

Random sequence genera- Unclear risk Comment: insufficient information to permit judgement. tion (selection bias)

Allocation concealment $\quad$ Unclear risk $\quad$ Comment: insufficient information to permit judgement.
(selection bias)

(selection bias)

Blinding of participants High risk Not feasible.
and personnel (perfor-
mance bias)

Blinding of outcome as- High risk Not feasible.

sessment (detection bias)

All outcomes

$\begin{array}{ll}\text { Incomplete outcome data Low risk } & \text { Comment: no missing data. All randomised participants included in the } \\ \text { (attrition bias) } & \text { study's analyses. }\end{array}$

All outcomes

Selective reporting (re- Low risk $\quad$ Planned outcomes reported.
porting bias)

porting bias)

Other bias Low risk No other sources of bias identified.

\section{Pakfetrat 2015}

Study design: RCT
Conducted in Iran (Department of Ora Medicine, Mashhad Dental Faculty)
Number of centres: 1
Recruitment period: $2008-2010$
Funding source: Vice Chancellor for Research, Mashhad University of Medical Sciences

Participants

Inclusion criteria: adults with atrophic-erosive OLP as confirmed by biopsy, lesion size $<2 \mathrm{~cm}$; atrophic-erosive lesions limited to 2 sides of the oral cavity; no current treatment with immunomodulatory agents; a 1-week washout period was required prior to enrolment if participants were taking immunomodulatory agents.

Exclusion criteria: inability to undergo oral biopsy for diagnosis; aged $<18$ years; systemic diseases or malignancy, pregnancy, lesion/lesions with dysplasia; history of allergic reaction to corticosteroids or immunomodulatory drugs; presence of lesions adjacent to an amalgam filling

Group A: randomised 14; analysed 6

Group B: randomised 14; analysed 4

Interventions $\quad$ Group A: pimecrolimus 1\% cream, 3 times daily for 2 months
Group B: triamcinolone acetonide $0.1 \%$ in Orabase, 3 times daily for 2 months

Outcomes

Pain (VAS), clinical score (Thongprasom), improvement of lesions

Notes Reporting of VAS and clinical score values did not allow quantitative analysis. 
Pakfetrat 2015 (Continued)

Risk of bias

\begin{tabular}{|c|c|c|}
\hline Bias & Authors' judgement & Support for judgement \\
\hline $\begin{array}{l}\text { Random sequence genera- } \\
\text { tion (selection bias) }\end{array}$ & Low risk & $\begin{array}{l}\text { Quote: "Patients were randomly divided in two groups, based on a random } \\
\text { numbering table." }\end{array}$ \\
\hline $\begin{array}{l}\text { Allocation concealment } \\
\text { (selection bias) }\end{array}$ & Low risk & $\begin{array}{l}\text { Quote unpublished: "We used sealed envelopes for each patient for guarantee } \\
\text { allocation concealment." }\end{array}$ \\
\hline $\begin{array}{l}\text { Blinding of participants } \\
\text { and personnel (perfor- } \\
\text { mance bias) } \\
\text { All outcomes }\end{array}$ & High risk & Quote: "Patients were aware of the medication allocated." \\
\hline $\begin{array}{l}\text { Blinding of outcome as- } \\
\text { sessment (detection bias) } \\
\text { All outcomes }\end{array}$ & High risk & $\begin{array}{l}\text { Comment: participants (self-assessed, pain was primary outcome) were not } \\
\text { blinded. }\end{array}$ \\
\hline $\begin{array}{l}\text { Incomplete outcome data } \\
\text { (attrition bias) } \\
\text { All outcomes }\end{array}$ & High risk & $\begin{array}{l}8 / 14(57 \%) \text { participants from Group A and } 10 / 14(71 \%) \text { participants from Group } \\
\text { B were lost at the } 4 \text { th and } 5 \text { th visit. }\end{array}$ \\
\hline $\begin{array}{l}\text { Selective reporting (re- } \\
\text { porting bias) }\end{array}$ & Low risk & Planned outcomes reported. \\
\hline Other bias & Low risk & No other sources of bias identified. \\
\hline
\end{tabular}

\section{Rodstrom 1994}

\begin{tabular}{|c|c|}
\hline \multirow[t]{5}{*}{ Methods } & Study design: RCT \\
\hline & Conducted in: Sweden \\
\hline & Number of centres: 1 \\
\hline & Recruitment period: unspecified \\
\hline & Funding source: unspecified \\
\hline \multirow[t]{4}{*}{ Participants } & $\begin{array}{l}\text { Inclusion criteria: consecutive patients with clinical and histological diagnosis of OLP according to } \\
\text { WHO recommendations }\end{array}$ \\
\hline & Exclusion criteria: lesions adjacent to buccal or lingual amalgam fillings \\
\hline & Group A: randomised 20; analysed 17 \\
\hline & Group B: randomised 20; analysed 20 \\
\hline \multirow[t]{2}{*}{ Interventions } & $\begin{array}{l}\text { Group A: clobetasol propionate } 0.025 \% \text { ointment in Orabase }(50 / 50) \text { twice daily for first } 3 \text { weeks, once } \\
\text { daily for second } 3 \text { weeks, once every other day for third } 3 \text { weeks (total } 9 \text { weeks) }\end{array}$ \\
\hline & $\begin{array}{l}\text { Group B: triamcinolone acetonide } 0.1 \% \text { ointment in Orabase }(50 / 50) \text { twice daily for first } 3 \text { weeks, once } \\
\text { daily for second } 3 \text { weeks, once every other day for third } 3 \text { weeks (total } 9 \text { weeks) }\end{array}$ \\
\hline Outcomes & Pain (VAS), clinical score (4-grade score), adverse effects \\
\hline
\end{tabular}


Rodstrom 1994 (Continued)

Notes

\section{Risk of bias}

\begin{tabular}{|c|c|c|}
\hline Bias & Authors' judgement & Support for judgement \\
\hline $\begin{array}{l}\text { Random sequence genera- } \\
\text { tion (selection bias) }\end{array}$ & Unclear risk & Comment: "randomised" - insufficient information to permit judgement. \\
\hline $\begin{array}{l}\text { Allocation concealment } \\
\text { (selection bias) }\end{array}$ & Unclear risk & Comment: insufficient information to permit judgement. \\
\hline $\begin{array}{l}\text { Blinding of participants } \\
\text { and personnel (perfor- } \\
\text { mance bias) } \\
\text { All outcomes }\end{array}$ & Low risk & Quote: "Double blind." \\
\hline $\begin{array}{l}\text { Blinding of outcome as- } \\
\text { sessment (detection bias) } \\
\text { All outcomes }\end{array}$ & Low risk & Quote: "Double blind." \\
\hline $\begin{array}{l}\text { Incomplete outcome data } \\
\text { (attrition bias) } \\
\text { All outcomes }\end{array}$ & Low risk & $\begin{array}{l}\text { Comment: missing data were not likely to have a clinically relevant impact on } \\
\text { the intervention effect estimate }(3 / 40(7.5 \%)) \text {. It must be noted that lost partic- } \\
\text { ipants were all from the clobetasol group. Unlikely to have introduced bias. }\end{array}$ \\
\hline $\begin{array}{l}\text { Selective reporting (re- } \\
\text { porting bias) }\end{array}$ & High risk & $\begin{array}{l}\text { Comment: } \geq 1 \text { outcomes of interest were reported incompletely (standard de- } \\
\text { viations were missing) so data could not be entered in a meta-analysis. }\end{array}$ \\
\hline Other bias & Low risk & No other sources of bias identified. \\
\hline
\end{tabular}

Siponen 2017

$\begin{array}{ll}\text { Methods } & \text { Study design: 3-arm parallel RCT } \\ \text { Conducted in Finland } \\ \text { Number of centres: } 2 \text { (Oulu and Kuopio) } \\ \text { Recruitment period: June } 2014 \text { to December } 2014 \\ \text { Funding source: Finnish Dental Society Apollonia, EVO Funds Oulu University Hospital, EVO/VTR Funds } \\ \text { Kuopio University Hospital, Sigrid Juselius Foundation, and MRC Oulu University Hospital } \\ \text { Inclusion criteria: diagnosis of symptomatic OLP, clinical score } \geq 20 \text { (including VAS >0), aged > 18 years, } \\ \text { washout period of } 2 \text { weeks } \\ \text { Exclusion criteria: pregnancy or current nursing; allergy to TAC, other macrolides or other substances } \\ \text { used in the study medications; hepatic insufficiency; and use of medications that could have significant } \\ \text { interactions with TAC, including ciclosporin, erythromycin, rifamycin, posaconazole, itraconazole, ke- } \\ \text { toconazole, fluconazole, voriconazole, rifampicin, phenytoin and dabigatran } \\ \text { Group A: randomised 11; analysed } 11 \\ \text { Group B: randomised 7; analysed } 7 \\ \text { Group C: randomised 9; analysed } 9\end{array}$


Siponen 2017 (Continued)

Group B: triamcinolone acetonide ointment $0.1 \% 3$ times daily for 3 weeks

Group C: placebo (Orabase) 3 times daily for 3 weeks from baseline to week 3 , adverse events

Notes Since clinical score and pain were reported only as percentage of change from baseline, they were not included in the quantitative analysis.

\section{Risk of bias}

\begin{tabular}{|c|c|c|}
\hline Bias & Authors' judgement & Support for judgement \\
\hline $\begin{array}{l}\text { Random sequence genera- } \\
\text { tion (selection bias) }\end{array}$ & Low risk & Quote: "Computer-generated randomisation lists." \\
\hline $\begin{array}{l}\text { Allocation concealment } \\
\text { (selection bias) }\end{array}$ & Low risk & $\begin{array}{l}\text { Quote: "Allocation concealment was ensured by keeping the randomisation } \\
\text { lists in the care of one of the investigators (TS) who was not involved in the } \\
\text { clinical part of the study." }\end{array}$ \\
\hline $\begin{array}{l}\text { Blinding of participants } \\
\text { and personnel (perfor- } \\
\text { mance bias) } \\
\text { All outcomes }\end{array}$ & Low risk & Quote: "double blind." \\
\hline $\begin{array}{l}\text { Blinding of outcome as- } \\
\text { sessment (detection bias) } \\
\text { All outcomes }\end{array}$ & Low risk & Quote: "double blind." \\
\hline $\begin{array}{l}\text { Incomplete outcome data } \\
\text { (attrition bias) } \\
\text { All outcomes }\end{array}$ & Low risk & $\begin{array}{l}\text { ITT analysis. } 4 / 27 \text { (15\%) participants lost at follow-up, balanced across groups } \\
(2,1 \text { and } 1) .\end{array}$ \\
\hline $\begin{array}{l}\text { Selective reporting (re- } \\
\text { porting bias) }\end{array}$ & Low risk & Planned outcomes reported. \\
\hline Other bias & Low risk & No other sources of bias identified. \\
\hline
\end{tabular}

Sivaraman 2016

Study design: 3-arm RCT
Conducted in: India
Number of centres: 1 (Department of Oral Medicine and Radiology, Rajah Muthiah Dental College and
Hospital, Annamalai University)
Recruitment period: September 2012 to July 2013
Funding source: unspecified
Participants
Inclusion criteria: clinically symptomatic oral lesions confirmed by histologically to be OLP
Exclusion criteria: people who had undergone treatment for OLP within 4 weeks of study, pregnant or nursing women, skin lesions, and lesion extending to soft palate and tonsils
Group A: randomised 10; analysed 10 
Sivaraman 2016 (Continued)

Group B: randomised 10; analysed 10

Group C: randomised 10; analysed 10

Interventions $\quad$ Group A: clobetasol propionate $0.05 \%$ topical 4 times daily for 6 weeks
Group B: triamcinolone acetonide $0.1 \%$ topical 4 times daily for 6 weeks
Group C: tacrolimus $0.03 \%$ topical 4 times daily for 6 weeks

\begin{tabular}{ll}
\hline Outcomes & Complete resolution after 6 weeks \\
\hline Notes & Complete resolution: clinical resolution or having reticular lesions only \\
\hline
\end{tabular}

\section{Risk of bias}

\begin{tabular}{|c|c|c|}
\hline Bias & Authors' judgement & Support for judgement \\
\hline $\begin{array}{l}\text { Random sequence genera- } \\
\text { tion (selection bias) }\end{array}$ & Low risk & Quote: "using randomisation chart." \\
\hline $\begin{array}{l}\text { Allocation concealment } \\
\text { (selection bias) }\end{array}$ & Unclear risk & Insufficient information to permit judgement. \\
\hline $\begin{array}{l}\text { Blinding of participants } \\
\text { and personnel (perfor- } \\
\text { mance bias) } \\
\text { All outcomes }\end{array}$ & Unclear risk & $\begin{array}{l}\text { Insufficient information to permit judgement, apart from the title of the paper: } \\
\text { "triple-blind." }\end{array}$ \\
\hline $\begin{array}{l}\text { Blinding of outcome as- } \\
\text { sessment (detection bias) } \\
\text { All outcomes }\end{array}$ & Unclear risk & $\begin{array}{l}\text { Insufficient information to permit judgement, apart from the title of the paper: } \\
\text { "triple-blind." }\end{array}$ \\
\hline $\begin{array}{l}\text { Incomplete outcome data } \\
\text { (attrition bias) } \\
\text { All outcomes }\end{array}$ & Low risk & No missing data. All randomised participants included in the analysis. \\
\hline $\begin{array}{l}\text { Selective reporting (re- } \\
\text { porting bias) }\end{array}$ & Low risk & Planned outcomes reported. \\
\hline Other bias & Low risk & No other sources of bias identified. \\
\hline
\end{tabular}

\section{Thomas 2017}

\begin{tabular}{|c|c|}
\hline \multirow[t]{5}{*}{ Methods } & Study design: 3-arm RCT \\
\hline & Conducted in India \\
\hline & Number of centres: 1 \\
\hline & Recruitment period: December 2013 to August 2015 \\
\hline & Funding source: unspecified \\
\hline Participants & $\begin{array}{l}\text { Inclusion criteria: clinically and histopathologically confirmed OLP without dysplasia in histopatholog- } \\
\text { ical evaluation and willing to take part in study. Clinical diagnosis was based on the presence of inter- } \\
\text { lacing white striations with intermixed erythematous or ulcerative areas. Histopathological diagnosis } \\
\text { based on presence of hydropic degeneration of basal cell layer, dense subepithelial inflammatory infil- }\end{array}$ \\
\hline
\end{tabular}


Thomas 2017 (Continued)

trate; participants with symptomatic OLP, i.e. burning sensation, and who had not undergone any previous treatment for the same in the last 6 months.

Exclusion criteria: evidence of lichenoid reaction in clinical or histopathological assessment; having extra oral manifestations of OLP; long-term glucocorticosteroid therapy for other systemic diseases; with other white lesions such as leukoplakia; systemic lupus erythematosus along with OLP; pregnancy, breastfeeding; history of allergic reactions to corticosteroids or herbal preparations

Group A: randomised 25; analysed 25

Group B: randomised 25; analysed 19

Group C: randomised 25; analysed 25

\begin{tabular}{ll}
\hline Interventions & Group A: triamcinolone acetonide $0.1 \% 3$ times daily for 2 weeks \\
& $\begin{array}{l}\text { Group B: Curenext Oral Gel (Piramel, Health Care, India each gram of which contains curcuma longa ex- } \\
\text { tracts } 10 \mathrm{mg}) 3 \text { times daily for } 2 \text { weeks } \\
\text { Group C: Curenext Oral Gel (Piramel, Health Care, India each gram of which contains curcuma longa ex- } \\
\text { tracts } 10 \mathrm{mg}) 6 \text { times daily for } 2 \text { weeks }\end{array}$ \\
\hline Outcomes & Pain (numerical rating scale), clinical score (Modified Oral Mucositis Index) \\
\hline Notes & We compared the outcomes of group A and group C (highest Curenext Oral Gel dose).
\end{tabular}

\section{Risk of bias}

\begin{tabular}{lll}
\hline Bias & Authors' judgement & Support for judgement \\
\hline $\begin{array}{l}\text { Random sequence genera- } \\
\text { tion (selection bias) }\end{array}$ & Unclear risk & Insufficient information to permit judgement. \\
\hline $\begin{array}{l}\text { Allocation concealment } \\
\text { (selection bias) }\end{array}$ & Unclear risk & Insufficient information to permit judgement. \\
\hline $\begin{array}{l}\text { Blinding of participants } \\
\text { and personnel (perfor- } \\
\text { mance bias) } \\
\text { All outcomes }\end{array}$ & High risk & Not feasible. \\
\hline
\end{tabular}

$\begin{array}{ll}\text { Blinding of outcome as- } & \text { High risk } \quad \text { Not feasible. } \\ \text { sessment (detection bias) } & \end{array}$

All outcomes

$\begin{array}{ll}\begin{array}{l}\text { Incomplete outcome data } \\ \text { (attrition bias) }\end{array} & \text { Low risk } \\ \text { All outcomes } & \text { No missing data in the } 2 \text { groups considered for analysis. All randomised partic- } \\ \end{array}$

\begin{tabular}{lll}
\hline $\begin{array}{l}\text { Selective reporting (re- } \\
\text { porting bias) }\end{array}$ & Low risk & Planned outcomes reported. \\
\hline Other bias & Low risk & No other sources of bias identified. \\
\hline
\end{tabular}

Voute 1993

Methods Study design: RCT


Voute 1993 (Continued)

Conducted in: The Netherlands

Number of centres: 1

Recruitment period: unspecified

Funding source: company provided drugs

\begin{tabular}{|c|c|}
\hline \multirow[t]{4}{*}{ Participants } & $\begin{array}{l}\text { Inclusion criteria: clinical features, his } \\
\text { non-use of medication and the absenc }\end{array}$ \\
\hline & Exclusion criteria: unspecified \\
\hline & Group A: randomised 20; analysed 20 \\
\hline & Group B: randomised 20; analysed 20 \\
\hline
\end{tabular}

Interventions

Group A: fluocinonide $0.025 \%$ in $40 \%$ hypromellose ointment in white soft paraffin least 6 times daily for 9 weeks

Group B: placebo at least 6 times daily for 9 weeks

Outcomes Pain (5-grade score: complete, good, partial, no effect, increase), clinical score (5-grade score: com-
plete, good, partial, no effect, increase)

Notes

Risk of bias

\begin{tabular}{|c|c|c|}
\hline Bias & Authors' judgement & Support for judgement \\
\hline $\begin{array}{l}\text { Random sequence genera- } \\
\text { tion (selection bias) }\end{array}$ & Unclear risk & $\begin{array}{l}\text { Quote: "randomised." } \\
\text { Insufficient information to permit judgement. }\end{array}$ \\
\hline $\begin{array}{l}\text { Allocation concealment } \\
\text { (selection bias) }\end{array}$ & Unclear risk & Insufficient information to permit judgement. \\
\hline $\begin{array}{l}\text { Blinding of participants } \\
\text { and personnel (perfor- } \\
\text { mance bias) } \\
\text { All outcomes }\end{array}$ & Low risk & Quote: "Double blind." \\
\hline $\begin{array}{l}\text { Blinding of outcome as- } \\
\text { sessment (detection bias) } \\
\text { All outcomes }\end{array}$ & Low risk & Quote: "Double blind." \\
\hline $\begin{array}{l}\text { Incomplete outcome data } \\
\text { (attrition bias) } \\
\text { All outcomes }\end{array}$ & Low risk & No missing data. All randomised participants included in the result analysis. \\
\hline $\begin{array}{l}\text { Selective reporting (re- } \\
\text { porting bias) }\end{array}$ & Low risk & No other sources of bias identified. \\
\hline Other bias & Low risk & No other sources of bias identified. \\
\hline
\end{tabular}


Wei 2003

\begin{tabular}{|c|c|}
\hline \multirow[t]{5}{*}{ Methods } & Study design: RCT \\
\hline & Conducted in China \\
\hline & Number of centres: 1 \\
\hline & Recruitment period: unspecified \\
\hline & Funding source: unspecified \\
\hline \multirow[t]{4}{*}{ Participants } & $\begin{array}{l}\text { Inclusion criteria: clinical demonstration of hyperaemic OLP, pathological examination confirmed the } \\
\text { diagnosis of OLP, history of OLP for } \geq 3 \text { months }\end{array}$ \\
\hline & $\begin{array}{l}\text { Exclusion criteria: OLP did not locate in the buccal mucosa, with other oral mucosa diseases or system- } \\
\text { atic diseases, first-onset OLP or history }<3 \text { months, already taking local or systematic therapy in the } \\
\text { past } 3 \text { months, OLP after the treatment of orthodontics and metallic full crown }\end{array}$ \\
\hline & Group A: randomised 37; analysed 37 \\
\hline & Group B: randomised 20; analysed 20 \\
\hline \multirow[t]{2}{*}{ Interventions } & Group A: alternative use of mycostatin paste and dexamethasone paste (twice daily each) for 6 weeks \\
\hline & Group B: dexamethasone paste (4 times daily) for 6 weeks \\
\hline Outcomes & Clinical score (4-grade score) \\
\hline Notes & \\
\hline
\end{tabular}

\section{Risk of bias}

\begin{tabular}{|c|c|c|}
\hline Bias & Authors' judgement & Support for judgement \\
\hline $\begin{array}{l}\text { Random sequence genera- } \\
\text { tion (selection bias) }\end{array}$ & Unclear risk & Method of sequence generation not described by translator. \\
\hline $\begin{array}{l}\text { Allocation concealment } \\
\text { (selection bias) }\end{array}$ & Unclear risk & Insufficient information to permit judgement. \\
\hline $\begin{array}{l}\text { Blinding of participants } \\
\text { and personnel (perfor- } \\
\text { mance bias) } \\
\text { All outcomes }\end{array}$ & Low risk & Quote: "Double blind." \\
\hline $\begin{array}{l}\text { Blinding of outcome as- } \\
\text { sessment (detection bias) } \\
\text { All outcomes }\end{array}$ & Low risk & Quote: "Double blind." \\
\hline $\begin{array}{l}\text { Incomplete outcome data } \\
\text { (attrition bias) } \\
\text { All outcomes }\end{array}$ & Low risk & No missing data. All randomised participants included in analysis. \\
\hline $\begin{array}{l}\text { Selective reporting (re- } \\
\text { porting bias) }\end{array}$ & Unclear risk & Insufficient information to permit judgement. \\
\hline Other bias & Low risk & No other sources of bias identified. \\
\hline
\end{tabular}


Xiong 2009

Study design: RCT
Conducted in China
Number of centres: 1
Recruitment period: July 2005 to January 2006
Funding source: study supported by grants from the National Natural Science Foundation of China
(No.30872873, No.30572041) and the Program for New Century Excellent Talents in University.

Participants

Inclusion criteria: erosive area not exceeding $1 \mathrm{~cm}^{2}$; disease process exceeding 2 months; and normal physical examination before medication (including complete blood cell count, and renal and hepatic clinical chemistry examination, urine and stool routine test, blood pressure examination, ultrasonic examination of abdomen, chest $\mathrm{x}$-ray and electrocardiogram)

Exclusion criteria: severe systemic diseases or other severe oral mucous diseases; taking immunopotentiating or immunosuppressive agents during the previous 3 months; having topical treatment within 1 week; lichenoid reaction caused by the amalgam fillings or certain drugs; pregnancy or breastfeeding period; and not taking drugs under the medical orders or not finishing the return visits and follow-up review

Group A: randomised 31; analysed 28

Group B: randomised 25; analysed 25

Interventions

Group A: Bacillus Calmette-Guerin polysaccharide nucleic acid, $0.5 \mathrm{~mL}$ intralesional injection every other day, until either erosive lesion disappeared or for 2 weeks. Total 6 injections

Group B: triamcinolone acetonide $10 \mathrm{mg}(0.25 \mathrm{~mL}$ from solution $40 \mathrm{mg} / \mathrm{mL})$ mixed $0.25 \mathrm{~mL}$ of $2 \%$ lidocaine solution, intralesional injection, once weekly for 2 weeks. Total 2 injections

Outcomes Pain (VAS), size of erosive area, adverse reactions

Notes

\section{Risk of bias}

\begin{tabular}{|c|c|c|}
\hline Bias & Authors' judgement & Support for judgement \\
\hline $\begin{array}{l}\text { Random sequence genera- } \\
\text { tion (selection bias) }\end{array}$ & Low risk & Quote: "random number table." \\
\hline $\begin{array}{l}\text { Allocation concealment } \\
\text { (selection bias) }\end{array}$ & Unclear risk & Insufficient information to permit judgement. \\
\hline $\begin{array}{l}\text { Blinding of participants } \\
\text { and personnel (perfor- } \\
\text { mance bias) } \\
\text { All outcomes }\end{array}$ & High risk & Not feasible. \\
\hline $\begin{array}{l}\text { Blinding of outcome as- } \\
\text { sessment (detection bias) } \\
\text { All outcomes }\end{array}$ & High risk & Not feasible. \\
\hline $\begin{array}{l}\text { Incomplete outcome data } \\
\text { (attrition bias) } \\
\text { All outcomes }\end{array}$ & High risk & $\begin{array}{l}\text { Missing data were unlikely to have a clinically relevant impact on the interven- } \\
\text { tion effect estimate ( } 3 / 56(5.3 \%) \text { participants). It must be noted that the lost } \\
\text { participants were all from the Bacillus Calmette-Guerin group. Unlikely to have } \\
\text { introduced bias. }\end{array}$ \\
\hline
\end{tabular}


Xiong 2009 (Continued)

Selective reporting (re- Low risk Important outcomes and adverse effects reported.
porting bias)

Other bias Low risk No other sources of bias identified.

Xu 2002

\begin{tabular}{ll}
\hline Methods & Study design: RCT \\
Conducted in China \\
Number of centres: 1 \\
Recruitment period: unclear \\
Funding source: unspecified
\end{tabular}

Participants Inclusion criteria: clinical and histopathological diagnosis of OLP

Exclusion criteria: systemic diseases, other oral mucosa diseases or advanced periodontal diseases; any immunomodulating drug in last 3 months

Group A: randomised 20; analysed 20

Group B: randomised 19; analysed 19

Interventions

Group A: 3-step treatment by traditional and Western medicine combined (herbal topical and decoction + prednisone $5-10 \mathrm{mg} 3$ times daily chlorphenamine $4 \mathrm{mg} 3$ times daily, vitamin $\mathrm{C} 0.1 \mathrm{~g} 3$ times daily). Herbal treatment applied topically, followed by herbal decoction + decreasing doses of Western medicine, followed by herbal decoction only. Treatment duration 6 weeks

Group B: Western medicine (prednisone 5-10 mg 3 times daily, chlorphenamine $4 \mathrm{mg} 3$ times daily, vitamin C $0.1 \mathrm{~g} 3$ times daily), dosage gradually decreased over 4-week period

Outcomes Clinical score (4-grade score), relapse rate

\section{Notes}

\section{Risk of bias}

\begin{tabular}{|c|c|c|}
\hline Bias & Authors' judgement & Support for judgement \\
\hline $\begin{array}{l}\text { Random sequence genera- } \\
\text { tion (selection bias) }\end{array}$ & Unclear risk & $\begin{array}{l}\text { Quote: "randomised trial." } \\
\text { Method of sequence generation not available. }\end{array}$ \\
\hline $\begin{array}{l}\text { Allocation concealment } \\
\text { (selection bias) }\end{array}$ & Unclear risk & Insufficient information to permit judgement. \\
\hline $\begin{array}{l}\text { Blinding of participants } \\
\text { and personnel (perfor- } \\
\text { mance bias) } \\
\text { All outcomes }\end{array}$ & High risk & Not feasible. \\
\hline $\begin{array}{l}\text { Blinding of outcome as- } \\
\text { sessment (detection bias) } \\
\text { All outcomes }\end{array}$ & High risk & Not feasible. \\
\hline
\end{tabular}


Xu 2002 (Continued)

Incomplete outcome data Low risk No missing data. All randomised participants included in result analysis. (attrition bias)

No missing data. All randomised participants included in result analysis.

All outcomes

Selective reporting (re- Unclear risk Insufficient information to permit judgement.
porting bias)

\begin{tabular}{ll}
\hline Other bias $\quad$ Low risk $\quad$ No other sources of bias identified. \\
\hline
\end{tabular}

Yoke 2006

Study design: RCT
Conducted in Singapore, South Korea, India, Thailand
Number of centres: 4: Singapore, Seoul (South Korea), Madras (India), Bangkok (Thailand)
Recruitment period: $2000-2003$
Funding source: National Medical Research Council, Ministry of Health, Singapore. Trident Pharm Pte
Ltd (Singapore) assisted with the distribution of Kenalog to the overseas centres; Novartis Pte Ltd (Sin-
gapore) provided Sandimmun Neoral (ciclosporin) at cost for the trial and assisted in co-ordinating the
trial supplies at the overseas centres

Participants Inclusion criteria: histologically confirmed OLP and with both clinical signs and symptoms of OLP requiring treatment

Exclusion criteria: treated previously by either of the trial medications and had worsened during that treatment or had uncontrolled or severe hypertension, serious active or recurrent infections, severe respiratory, renal, or heart disease, recent history of malignancy, insulin-dependent diabetes, active peptic ulcer disease, active inflammatory gastrointestinal disease or pregnancy

Group A: randomised 71; analysed 71

Group B: randomised 68; analysed 68

Interventions $\quad$ Group A: ciclosporin solution $0.1 \%, 3$ times daily for 8 weeks
Group B: triamcinolone acetonide $0.1 \%$ in Orabase, 3 times daily for 8 weeks

\begin{tabular}{lll}
\hline Outcomes & Pain (VAS), clinical score (Thongprasom) \\
\hline Notes & & \\
\hline Risk of bias & Authors' judgement & Support for judgement \\
\hline Bias & Low risk & $\begin{array}{l}\text { Quote: "patients were randomly assigned to receive steroid or cyclosporin } \\
\text { through central randomization office of the Clinical trials and Epidemiology } \\
\text { Research Unit, Singapore." }\end{array}$ \\
\hline $\begin{array}{ll}\text { Random sequence genera- } \\
\text { tion (selection bias) }\end{array}$ & $\begin{array}{l}\text { Quote: "Once eligibility had been confirmed [...] patients were randomly as- } \\
\text { signed [...] by telephone (Singapore and South Korea) or sealed envelope (In- } \\
\text { dia and Thailand)." }\end{array}$ \\
\hline $\begin{array}{l}\text { Allocation concealment } \\
\text { (selection bias) }\end{array}$ & Low risk & \\
\hline
\end{tabular}


Yoke 2006 (Continued)
Blinding of participants
Unclear risk
Comment: insufficient information to permit judgement. and personnel (performance bias)

All outcomes

\begin{tabular}{lll}
\hline $\begin{array}{l}\text { Blinding of outcome as- } \\
\text { sessment (detection bias) }\end{array}$ & Unclear risk & Comment: insufficient information to permit judgement. \\
$\begin{array}{ll}\text { All outcomes } \\
\text { Incomplete outcome data }\end{array}$ & Low risk & $\begin{array}{l}\text { ITT analysis. 23/139 (16.5\%) participants lost at follow-up, balanced (13 and } \\
\text { (attrition bias) }\end{array}$ \\
$\begin{array}{ll}\text { All outcomes } & \text { 10). }\end{array}$
\end{tabular}

\begin{tabular}{lll}
\hline $\begin{array}{l}\text { Selective reporting (re- } \\
\text { porting bias) }\end{array}$ & Low risk & Clinical improvement, pain and adverse effects reported. \\
\hline Other bias & Low risk & No other sources of bias identified. \\
\hline
\end{tabular}

EI: Efficacy Index; ITT: intention to treat; LED: light-emitting diode; LP: lichen planus; OHIP: Oral Health Impact Profile; OHQoL: Oral Health related Quality of Life; OLP: oral lichen planus; RCT: randomised controlled trial; UVB: ultraviolet B; VAS: visual analogue scale; WHO: World Health Organization.

\section{Characteristics of excluded studies [ordered by study ID]}

\begin{tabular}{|c|c|}
\hline Study & Reason for exclusion \\
\hline Agarwal 2013 & Included people without symptoms. \\
\hline Agha-Hosseini 2010 & $\begin{array}{l}\text { Evaluated purslane vs placebo. Included in previous version of the review, which has now been } \\
\text { split into } 2 \text {. Will be included in non-corticosteroid review (in preparation). }\end{array}$ \\
\hline Amirchaghmaghi 2014 & Included people without symptoms. \\
\hline Arbabi-Kalati 2017 & Not a randomised clinical trial. \\
\hline Azizi 2015 & Not a randomised clinical trial (quasi-randomised). \\
\hline Bakhtiar 2018 & Included participants with lichen planus without oral lesions. \\
\hline Boisnic 1994 & Study author informed us that they included people without symptoms. \\
\hline Bouloc 2000 & Included participants with lichen planus without oral lesions. \\
\hline Buajeeb 1997 & Included people without symptoms. \\
\hline Buajeeb 2000 & Included people without symptoms. \\
\hline Chang 2008 & $\begin{array}{l}\text { Included people without symptoms; not all participants underwent biopsy; included participants } \\
\text { with lichen planus without oral lesions. }\end{array}$ \\
\hline Choonhakarn 2008 & $\begin{array}{l}\text { Evaluated aloe vera vs placebo. Included in previous version of the review, which has now been } \\
\text { split into } 2 \text {. Will be included in non-corticosteroid review (in preparation). }\end{array}$ \\
\hline Cilurzo 2010 & Included people without symptoms. \\
\hline
\end{tabular}




\begin{tabular}{|c|c|}
\hline Study & Reason for exclusion \\
\hline Delavarian 2010 & $\begin{array}{l}\text { Study included OLP with psychiatric disorders only and did not specify whether all participants } \\
\text { were symptomatic. }\end{array}$ \\
\hline Eisen 1990 & $\begin{array}{l}\text { Evaluated ciclosporin rinse vs placebo. Included in previous version of the review, which has now } \\
\text { been split into } 2 \text {. Will be included in non-corticosteroid review (in preparation). }\end{array}$ \\
\hline Gaeta 1994 & $\begin{array}{l}\text { Evaluated ciclosporin in bioadhesive gel vs bioadhesive gel. Included in previous version of the re- } \\
\text { view, which has now been split into } 2 \text {. Will be included in non-corticosteroid review (in prepara- } \\
\text { tion). }\end{array}$ \\
\hline Giustina 1986 & Included people without symptoms. \\
\hline Glade 1998 & Included participants with lichen planus without oral lesions. \\
\hline Greenspan 1978 & Not all participants underwent biopsy. \\
\hline Gunther 1973 & Not a randomised clinical trial. \\
\hline Hantash 2007 & Included participants with lichen planus without oral lesions. \\
\hline Harpenau 1995 & Not a randomised clinical trial (quasi-randomised). \\
\hline Hersle 1982 & Included people without symptoms. \\
\hline Jajarm 2011 & Included people without symptoms. \\
\hline Javadzadeh 2008 & Included people without symptoms. \\
\hline Joshy 2018 & Participants did not receive an histological diagnosis. \\
\hline Kellett 1990 & $\begin{array}{l}\text { Not all participants underwent biopsy and the study included participants with lichen planus with- } \\
\text { out oral lesions. }\end{array}$ \\
\hline Laurberg 1991 & Included participants with lichen planus without oral lesions. \\
\hline Lee 2013 & Included people without symptoms. \\
\hline Lin 2005 & Included people without symptoms. \\
\hline
\end{tabular}

Lundquist $1995 \quad$ Evaluated methoxsalen and ultraviolet A irradiation vs no treatment. Included in previous version of the review, which has now been split into 2 . Will be included in non-corticosteroid review (in preparation).

\begin{tabular}{ll}
\hline Mansourian 2011 & Included people without symptoms. \\
\hline McCaughey 2010 & Included people without symptoms. \\
\hline Mirza 2018 & Included people without symptoms. \\
\hline Mostafa 2018 & Included people without symptoms. \\
\hline Mousavi 2009 & $\begin{array}{l}\text { Evaluated Ignatia vs placebo. Included in previous version of the review, which has now been split } \\
\text { into 2. Will be included in non-corticosteroid review. }\end{array}$ \\
\hline
\end{tabular}




\begin{tabular}{|c|c|}
\hline Study & Reason for exclusion \\
\hline Nolan 2009 & $\begin{array}{l}\text { Evaluated topical hyaluronic acid vs placebo. Included in previous version of the review, which has } \\
\text { now been split into } 2 \text {. Will be included in non-corticosteroid review (in preparation). }\end{array}$ \\
\hline Passeron 2007 & $\begin{array}{l}\text { Evaluated pimecrolimus vs placebo. Included in previous version of the review, which has now } \\
\text { been split into } 2 \text {. Will be included in non-corticosteroid review (in preparation). }\end{array}$ \\
\hline Radfar 2008 & Included people without symptoms. \\
\hline Reddy 2012 & Included people without symptoms. \\
\hline Riaz 2017 & Clinically diagnosed oral lichen planus. \\
\hline Salazar-Sánchez 2010 & $\begin{array}{l}\text { Evaluated aloe vera vs placebo. Included in previous version of the review, which has now been } \\
\text { split into } 2 \text {. Will be included in non-corticosteroid review (in preparation). }\end{array}$ \\
\hline Singh 2017 & $16 / 40$ participants did not receive an histological diagnosis. \\
\hline Swift 2005 & $\begin{array}{l}\text { Evaluated pimecrolimus vs placebo. Included in previous version of the review, which has now } \\
\text { been split into } 2 \text {. Will be included in non-corticosteroid review (in preparation). }\end{array}$ \\
\hline Tyldesley 1977 & Not all participants underwent biopsy. \\
\hline Volz 2008 & $\begin{array}{l}\text { Evaluated pimecrolimus vs placebo. Included in previous version of the review, which has now } \\
\text { been split into } 2 \text {. Will be included in non-corticosteroid review (in preparation). }\end{array}$ \\
\hline Wu 2010 & Included people without symptoms. \\
\hline
\end{tabular}

Characteristics of studies awaiting assessment [ordered by study ID]

Fricain 2014

\begin{tabular}{ll}
\hline Methods & Multicentric, double-blind, randomised trial \\
\hline Participants & Randomised 75 participants with biopsy-confirmed OLP; analysed 75 \\
\hline Interventions & Topical betamethasone or rapamycin \\
\hline Outcomes & Total healing of erosion at 3 months, pain, adverse effects \\
\hline Notes & \\
\hline
\end{tabular}

\section{Qu 2016}

\begin{tabular}{ll}
\hline Methods & RCT \\
\hline Participants & 100 \\
\hline Interventions & "Western medical method" vs "integrated Chinese and Western medicine treatment" \\
\hline Outcomes & Oral mucosa examined at 1 month, recurrence (1-year follow-up)
\end{tabular}


Qu 2016 (Continued)

Notes

OLP: oral lichen planus; RCT: randomised controlled trial.

Characteristics of ongoing studies [ordered by study ID]

\section{7-002193-40}

Trial name or title

A randomized, double-blind, placebo-controlled, parallel group clinical study to assess the safety and efficacy of three doses of clobetasol propionate when administered intra-orally twice daily in patients with oral lichen planus (OLP) using Rivelin ${ }^{\circledR}$-CLO patches

Methods $\quad$ Parallel, double-blind RCT

Multiple sites and in multiple countries (Canada, Denmark, Germany, Ireland, the UK, the USA)

\section{Participants}

Adults (120 aged 18-65 years and 120 aged $>65$ years)

Inclusion criteria: people with OLP aged $\geq 18$ years with $\geq 1$ visible and measurable symptomatic ulcerative OLP lesion, assessable via OLPClinROM; clinical diagnosis of symptomatic OLP with a total score $\geq 5$ for $\geq 4$ days during week prior to baseline/randomisation visit, when summarising the individual scores of items \#1-7 of the OLPSSM; diagnosis of lichen planus histologically confirmed by result of existing clinically relevant biopsy or a new clinically representative biopsy taken at first screening visit (i.e. biopsy report indicative of OLP, lichen planus or lichenoid inflammation; written informed consent form signed and dated by participant following receipt of verbal and written information about study; practicing daily oral hygiene (by tooth brushing or mouthrinse, or both) and willing to maintain at least their routine oral hygiene procedure during study participation; willingness to keep already used permitted concomitant medication, food supplements (e.g. probiotics) or herbals, which might have in the discretion of the investigator a potential influence on OLP, on a stable basis from second screening (visit 1 ) to the end of study (visit 7); only if a diagnostic biopsy needs to be taken at first screening visit: complete healing of biopsy wound, including complete relief of pain associated with the biopsy site (defined as no/no further need to use any pain relief medication) at date of the second screening visit (visit 1 ).

\begin{tabular}{ll}
\hline Interventions & Groups A-D: clobetasol propionate patches (4 treatment arms - different doses) \\
& $\begin{array}{l}\text { Group E: placebo } \\
\text { 4-week treatment }\end{array}$ \\
\hline Outcomes & Primary: change in ulcer area from baseline (visit 2) to mean of visit 5 and visit 6 \\
\hline Starting date & 4 April 2018 \\
\hline Contact information & alexandra.greindl@proinnovera.com \\
\hline Notes & Sponsor: Dermtreat ApS
\end{tabular}

\section{ChicTR1800016507}

Trial name or title An evaluation on the short-term efficacy and safety of $0.01 \%$ compound betamethasone mouth rinse in treatment of oral erosion lichen planus: a randomized controlled clinical trial

Methods

\section{Parallel RCT}

China 
ChiCTR1800016507 (Continued)
Participants
Adults with OLP
Inclusion criteria: people with OLP aged 18-60 years
Exclusion criteria: people with severe systemic diseases that cannot be controlled by medicine

\begin{tabular}{ll}
\hline Interventions & Group A: $0.01 \%$ betamethasone mouthrinse \\
& Group B: $0.02 \%$ dexamethasone mouthrinse \\
\hline Outcomes & Lesion size, pain level, plasma concentration, healing rate, recurrence rate \\
\hline Starting date & Not reported \\
\hline Contact information & www.chictr.org.cn/com/25/showprojen.aspx?.proj=28090 \\
\hline Notes & Website in Chinese \\
\hline
\end{tabular}

\section{CTRI/2018/03/012661}

\begin{tabular}{|c|c|}
\hline Trial name or title & Use of curcumin (turmeric) in treatment of oral ulcers due to lichen planus \\
\hline \multirow[t]{2}{*}{ Methods } & Parallel RCT \\
\hline & India \\
\hline \multirow[t]{3}{*}{ Participants } & People affected by OLP \\
\hline & Inclusion criteria: diagnosed cases of OLP \\
\hline & Exclusion criteria: pregnant women, not willing to participate, on other medications \\
\hline \multirow[t]{2}{*}{ Interventions } & $\begin{array}{l}\text { Group A: curcumin in tablet form } 2000 \mathrm{mg} / \text { day ( } 500 \mathrm{mg} \text { per tablet): oral administration of } 2 \text { tablets } \\
\text { in morning and } 2 \text { tablets in evening for } 6 \text { months }\end{array}$ \\
\hline & $\begin{array}{l}\text { Group B: clobetasol propionate ointment } 0.05 \% \text { : topical application for } 3 \text { times daily for } 1 \text { month, } \\
\text { twice daily for next } 2 \text { months and once daily for following } 3 \text { months }\end{array}$ \\
\hline \multirow[t]{2}{*}{ Outcomes } & Reduction in burning sensation, size of lesion and reduction in erythema \\
\hline & Time points: 15 days; $1,3,6$ months \\
\hline Starting date & Not reported \\
\hline \multicolumn{2}{|l|}{ Contact information } \\
\hline Notes & \\
\hline
\end{tabular}

\section{CTRI/2018/08/015185}

\begin{tabular}{ll}
\hline Trial name or title & Treatment for the local application of oral ulcers seen in oral lichen planus \\
\hline Methods & Parallel, multiple arm, RCT \\
& India \\
\hline
\end{tabular}


CTRI/2018/08/015185 (Continued)
Participants
Adults affected by OLP
Inclusion criteria: clinically determined cases of OLP; histopathologically confirmed cases of OLP; aged 20-65 years; individuals compliant and ready for study procedure and who will give written consent to undergo the study willingly.
Exclusion criteria: asymptomatic; history of use of antibiotics within 1 month or immunomodulat- ing agents within 3 months; presence of lichenoid reactions caused by amalgam fillings, drugs, etc; pregnant women and nursing mothers; uncontrolled diabetes mellitus, hypertension, acidity, im- munocompromised conditions; history of allergy or hypersensitivity to drugs under trial; unwilling to undergo the study and do not give informed consent.

Interventions

Group A (intervention 1): clobetasol propionate $0.05 \%$ ointment topically using finger on all involved surfaces and to keep it there for 15 minutes followed by rinsing with cold water. Participant will be recalled and assessed every week for 1 month, then recalled every 15 days for next 2 months.

Group B (intervention 2): Nano Bio Fusion gel (NBF): natural product consisting of vitamin E, vitamin $\mathrm{C}$ and Propolis, which has anti-inflammatory and antioxidant properties. Topical application 3 times daily for 1 month. Recall every week for first month and then every 15 days for next 3 months.

Group C (intervention 3): topical curcumin oral gel, which has anti-inflammatory properties. Topical application 3 times daily for 1 month. Recall every week for first month and then every 15 days for next 3 months.

Group D (control 1): Nano Bio Fusion gel (NBF) topically using finger on all involved surfaces and to keep it there for 15 minutes followed by rinsing with cold water. Participant will be recalled and assessed every week for 1 month, then recalled every 15 days for next 2 months.

Group E (control 2): topical curcumin oral gel topically using finger on all involved surfaces and to keep it there for 15 minutes followed by rinsing with cold water. Participant will be recalled and assessed every week for 1 month, then recalled every 15 days for next 2 months.

\begin{tabular}{ll}
\hline Outcomes & $\begin{array}{l}\text { Primary outcomes: burning sensation (VAS), clinical improvement of the lesion (Escudier scale) } \\
\text { Secondary outcomes: mucosal atrophy, candidiasis, estimation of malignant transformation rate } \\
\text { of OLP }\end{array}$ \\
\hline Starting date & 30 October 2017 \\
\hline Contact information & Dr Priyanka Verma, priyankavermamds@gmail.com \\
\hline Notes & Sponsor: Maulana Azad Institute of Dental Sciences \\
\hline
\end{tabular}

\section{CTRI/2018/08/015563}

\begin{tabular}{ll}
\hline Trial name or title & Benefits of neem for oral lichen planus patients \\
\hline Methods & Randomised, parallel group, multiple arm trial \\
& India \\
\hline Participants & People with symptoms of OLP attending OPD of Oral Medicine and Radiology Department of \\
S.P.D.C. DMIMS Sawangi, Wardha, India & Inclusion criteria: adults with symptoms aged 16-70 years with any clinical types and manifesta- \\
tions of OLP, confirmed histopathologically; people who have discontinued previous treatment for \\
OLP for last 6 months.
\end{tabular}


Exclusion criteria: < 16 years; with skin lesions; with non-symptomatic OLP lesions; with lesions showing malignant or dysplasic changes; undergoing any other treatment for OLP; pregnant and breastfeeding women; having systemic problems or under any medications for the same; having habit of chewing tobacco and betel nut or smoking.

Interventions

Group A (intervention 1): clobetasol $(0.05 \%)+$ nystatin $(100,000 \mathrm{IU} / \mathrm{mL})$ mouthwash and neem leaves extract mouthwash (5-20\%). Participants asked to use mouthwash for 15 minutes, 3 times daily. 1 hour after using clobetasol + nystatin mouthwash, neem leaves extract mouthwash has to be used.

Group B (intervention 2): neem leaves mouthwash (5-20\%) 3 times daily.

Group C: (control): clobetasol $(0.05 \%)+$ nystatin $(100,000 \mathrm{IU} / \mathrm{mL})$ mouthwash 3 times daily.

\begin{tabular}{ll}
\hline Outcomes & $\begin{array}{l}\text { Primary outcomes: burning sensation (VAS); severity of lesions (Thongprasom) } \\
\text { Secondary outcome: acceptability of neem mouthwash; total duration required to decrease the } \\
\text { symptoms; recurrence of the lesions }\end{array}$ \\
\hline Starting date & 17 September 2018 \\
\hline Contact information & Dr Ashita Kalaskar, kalaskarashita@gmail.com \\
\hline Notes & Sponsor: PI \\
\hline
\end{tabular}

\section{Ferri 2018}

Trial name or title
Efficacy of photobiomodulation on oral lichen planus: a protocol study for a double-blind, randomised controlled clinical trial

Methods Randomised (1:1), parallel-group, controlled, single-centre, 3-month clinical trial

Participants

People with both clinical and histopathological diagnosis of OLP

Inclusion criteria: men and women aged $>18$ years diagnosed with symptomatic lesions of reticular, atrophic an erosive OLP, based on the clinical and histopathological criteria of the WHO (1978) and modified by van der Meij and van der Waal.

Exclusion criteria: ongoing cancer, pregnancy or breastfeeding; history of corticosteroids or nonsteroidal anti-inflammatory drugs treatment in last month; uncontrolled systemic disease; consumption of illicit drugs; use of medication associated with oral lichenoid reactions such as methyldopa, IFNa, imatinib or infliximab (or both); amalgam restoration near to OLP lesions or epithelial dysplasia (or both) in the histopathological examination

Group A: topical clobetasol propionate gel $0.05 \%$ for 30 consecutive days and with placebo laser twice weekly. Laser device will be positioned over lesion but will be switched off to mask the treatment. Participants will apply the clobetasol propionate gel $0.05 \%$ over the entire lesion 3 times daily. To prevent oral candidiasis, participants will use antimycotic solution (nystatin oral suspension $100,000 \mathrm{USP} / \mathrm{mL}$ ) once daily for 4 weeks

Group B: localised low-level laser therapy with a continuous wave diode laser (Laser Therapy XT, DMC Equipment, São Carlos, SP, Brazil; $660 \pm 10 \mathrm{~nm}$; power: $100 \mathrm{~mW}$; energy density: $177 \mathrm{~J} / \mathrm{cm}^{2}$; 5 -second exposure time per point and $0.5 \mathrm{~J}$ of total energy per point) applied directly to the surrounding oral mucosa and to the centre of OLP, always by the same operator, twice weekly for 4 weeks, totalling 8 sessions. Participants will use antimycotic solution (nystatin oral suspension 100 $000 \mathrm{USP} / \mathrm{mL}$ ) once daily for 4 weeks. 
Ferri 2018 (Continued)

Secondary outcome: clinical scores (Thongprasom); functional scores (Libelly); clinical resolution

(Carozzo); recurrence rate; quality of life (OHIP-14); Hospital Anxiety and Depression Scale

\begin{tabular}{ll}
\hline Starting date & November 2018 \\
\hline Contact information & Dr Maria Fernanda Setúbal Destro Rodrigues; fernandarodrigues@ usp.br \\
\hline Notes & No sponsors \\
\hline
\end{tabular}

\section{IRCT20171017036835N2}

\begin{tabular}{|c|c|}
\hline Trial name or title & The effect of vitamin D on oral lichen planus \\
\hline \multirow[t]{2}{*}{ Methods } & Randomised, double-blind, controlled trial (phase III) \\
\hline & Iran \\
\hline \multirow[t]{3}{*}{ Participants } & Men and women with OLP aged $18-80$ years \\
\hline & $\begin{array}{l}\text { Inclusion criteria: people with erosive-atrophic OLP who have not used any systemic or topical } \\
\text { drug for the treatment of lichen planus over past } 2 \text { weeks and have not used any vitamin supple- } \\
\text { ment in past } 3 \text { months; with vitamin D deficiency or insufficiency }(25(\mathrm{OH}) \mathrm{D}<30 \mathrm{mg} / \mathrm{dL}) \text {. }\end{array}$ \\
\hline & $\begin{array}{l}\text { Exclusion criteria: _. dy splasia or ichenoid reaction, calcium levels }>10 \mathrm{mg} / \mathrm{dL} \text {, phosphorus }< \\
2.5 \mathrm{mg} / \mathrm{dL} \text {, pregnancy, metabolic bone diseases such as osteomalacia and primary hyperparathy- } \\
\text { roidism, history of severe renal-hepatic dysfunction, allergy to vitamin } \mathrm{D} \text { supplements, usage of } \\
\text { barbiturates and phenytoin, granulomatous diseases, malabsorption or chronic pancreatitis }\end{array}$ \\
\hline \multirow[t]{2}{*}{ Interventions } & $\begin{array}{l}\text { Group A: dexamethasone mouthwash + nystatin mouthwash (Jaber ebne Hayan Company) will } \\
\text { be prescribed, } 2 \text { or } 3 \text { times daily, for } 8 \text { weeks. Additionally, vitamin D capsules } 50,000 \text { IU (manufac- } \\
\text { tured by Dana Pharmaceutical Company) will be prescribed, } 1 \text { pearl every week for } 8 \text { weeks }\end{array}$ \\
\hline & $\begin{array}{l}\text { Group B: dexamethasone mouthwash + nystatin mouthwash (Jaber ebne Hayan Company) will be } \\
\text { prescribed, } 2 \text { or } 3 \text { times daily, for } 8 \text { weeks. Additionally, placebo capsules filled with lactose and in } \\
\text { the same weight of vitamin D capsules will be prescribed, } 1 \text { capsule every week for } 8 \text { weeks. }\end{array}$ \\
\hline \multirow[t]{2}{*}{ Outcomes } & Primary outcome: burning and pain (VAS), type and severity of lesions (Thongprasom) \\
\hline & Secondary outcome: levels of vitamin D and cytokines (ELISA) \\
\hline Starting date & 23 March 2018 \\
\hline Contact information & Dr Zohreh Dalirsan, dalirsaniz@mums.ac.in \\
\hline Notes & Sponsor: Mashhad University of Medical Sciences \\
\hline
\end{tabular}

\section{IRCT20181226042133N1}

\section{Trial name or title}

Methods

Comparison of therapeutic effect of mucoadhesive nano-triamcinolone gel and conventional triamcinolone gel on oral lichen planus

Triple-blind, parallel, RCT

Iran 
IRCT20181226042133N1 (Continued)

Participants Men and women with definite diagnosis of lichen planus

Inclusion criteria: OLP clinical criteria and histopathology confirmed, aged 17-70 years, completion of written consent

Exclusion criteria: breastfeeding, use of drugs that cause lichenoid reactions usage of immunosuppressor drugs, sensitivity to Corton denture usage

\begin{tabular}{ll}
\hline $\begin{array}{l}\text { Interventions } \\
\text { Group A: nano-triamcinolone } \\
\text { Gutcomes }\end{array}$ & Primary outcomes: pain (VAS), size of lesions (paper lace), clinical score (Thongprasom) \\
\hline Starting date & 10 October 2016 \\
\hline Contact information & Dr Rastin Sadeghian; dr.rastinsadeghian@gmail.com \\
\hline Notes & Sponsor: Artesh University of Medical Sciences \\
& $\begin{array}{l}\text { Thongprasom scale, which categorises the phenotype of OPL lesions and includes } 6 \text { grades }(0= \\
\text { perfectly healthy, } 1=\text { mild white lines without inflammatory regions, } 2=\text { white lines with atrophic } \\
\text { regions }<1 \mathrm{~cm}^{2}, 3=\text { white lines with atrophic regions }>1 \mathrm{~cm}^{2}, 4=\text { white lines accompanied with ero- } \\
\text { sive regions }<1 \mathrm{~cm}^{2}, 5=\text { white lines with erosive areas }>1 \mathrm{~cm}^{2}\end{array}$
\end{tabular}

\section{NCT03386643}

Trial name or title

Effect of probiotic Bifidobacterium animalis subsp. lactis HNO19 on clinical, histopathological and immunophenotypic features of oral lichen planus

\begin{tabular}{ll}
\hline Methods & Parallel, double-blind RCT \\
& Brazil \\
\hline Participants & 22 adults \\
& $\begin{array}{l}\text { Inclusion criteria: men and women aged } \geq 18 \text { years old, consented to participate; with sympto- } \\
\text { matic reticular lesion or white-grey papules (or both). In afro-descendent people, reticular lesions } \\
\text { may be associated with hyperpigmented lesions; additional clinical features such as ulcerative, } \\
\text { erythematous, plaque and bullous lesions will be accepted in the presence of bilateral and sym- } \\
\text { metrical reticular lesions. }\end{array}$
\end{tabular}

Histopathological inclusion criteria: presence of subepithelial infiltrate predominantly lymphocytic, in band and confined to the subepithelial area; liquefaction degeneration of the basal cells layer.

Interventions

Group A: probiotic (Bifidobacterium animalis subsp. lactis HN019)

Group B: clobetasol propionate $0.05 \%$ mouthwash twice daily for 4 weeks

\begin{tabular}{ll}
\hline Starting date & 6 November 2017 \\
\hline Contact information & Ana Carolina Fragoso Motta \\
\hline
\end{tabular}


NCT03386643 (Continued)

Notes

Sponsor: University of Sao Paulo, Brazil

NCT03592342

\begin{tabular}{ll} 
Trial name or title & Intra-oral treatment of OLP with Rivelin ${ }^{\circledR}$-CLO patches \\
\hline Methods & Randomised, double-blind, placebo-controlled, parallel group clinical study \\
& Multicentre (Denmark, Germany, Ireland, the UK, the USA)
\end{tabular}

Participants

Inclusion criteria: people with OLP with $\geq 1$ visible and measurable symptomatic ulcerative OLP lesion, assessable via OLPClinROM; aged $\geq 18$ years; practising daily oral hygiene (by tooth brushing or mouthrinse (or both)) and willing to maintain at least their routine oral hygiene procedure during study participation; willingness to keep already used permitted concomitant medication, food supplements (e.g. probiotics) or herbals, which might have in the discretion of the investigator a potential influence on OLP, on a stable basis during the study.

Exclusion criteria: people requiring $>6$ patches (corresponding to approximately $3 \mathrm{~cm}^{2}$ per patch) to cover symptomatic ulcerative and erythematous OLP lesions at baseline visit; ongoing active visible fungal, bacterial or viral infection of oral mucosa, including ongoing treatment of those at baseline; with any un-healed oral surgery (including recent diagnostic biopsies, if applicable) or oral laser therapeutic wound(s) at baseline visit; any of the following systemic treatments prior to baseline visit: corticosteroids, antibiotics, retinoids, immunosuppressive drugs (e.g. azathioprine, ciclosporin, mycophenolate mofetil or biologics), antimycotics; any of the following topical treatments used in the oral cavity prior to baseline visit: corticosteroids, antibiotics, ciclosporin, tacrolimus, pimecrolimus, antimycotics, retinoids; phototherapy in oral cavity prior to baseline visit: UVB, PUVA; current participation in another clinical study or having received treatment with any non-marketed/investigational medicinal product (drug substance or medical device) within 4 weeks prior to screening; known or suspected intolerance/hypersensitivity/resistance to clobetasol propionate or any component of the investigational medicinal product; people who previously have failed to respond to OLP treatments with systemic glucocorticosteroids, methotrexate, ciclosporin, retinoids or azathioprine; history of squamous cell carcinoma (even if resected), and other non-squamous cell carcinoma (e.g. sarcoma, salivary gland tumours) that have been managed with radiation or chemotherapy; history of cancer (except resected cutaneous basal cell carcinoma and except in situ cervical cancer) unless it can be documented that the patient has been in a disease-free state for $\geq 5$ years. In case of clinical suspicion of malignancy in the oral cavity, a patient can only be included after an excluding biopsy; professional dental cleaning within 2 weeks prior to baseline and unwillingness to refrain from professional dental cleaning during study conduct; close affiliation with the investigator (e.g. a close relative) or people working at the study sites or patient who is an employee of the sponsor's company; pregnant, confirmed by a positive pregnancy test, or breastfeeding women, or women planning to become pregnant or not using or willing to continue to use a defined highly effective method of contraception.

Interventions Group A (intervention 1): Rivelin ${ }^{\circledR}-$ CLO clobetasol propionate patch $1 \mu \mathrm{g}$ twice daily (morning and evening).

Group B (intervention 2): Rivelin ${ }^{\circledR}$-CLO clobetasol propionate patch $5 \mu \mathrm{g}$ twice daily (morning and evening).

Group C (intervention 3): Rivelin ${ }^{\circledR}$-CLO clobetasol propionate patch $20 \mu \mathrm{g}$ twice daily (morning and evening).

Group D (control): Rivelin ${ }^{\circledast}$ plain patches twice daily (morning and evening).

Outcomes

Primary outcome: change in ulcer area

Secondary outcomes: change in lesion area, change in 5-point erythema score, change in Clinical Global Impression Score, change in OLPSSM total score (items \#1-7), change in individual diary 
NCT03592342 (Continued)

symptom scores (items \#1-7 of the OLPSSM), change in worst symptoms at anatomical sites, proportion of positive outcomes (score 0 or 1 ) on each of the 11 questions in the Patch Sensation Questionnaire, proportion of participants with successful ( $\geq 80 \%$ of days on treatment) patch applications, Incidence of treatment-emergent adverse events (safety and tolerability)

\begin{tabular}{ll}
\hline Starting date & June 2018 \\
\hline Contact information & Pia Jensen, pj@dermtreat.com \\
\hline Notes & Sponsors: Dermtreat, Proinnovera GmbH, X-act Cologne Research GmbH \\
& One review author, Marco Carrozzo, is involved in this trial. \\
\hline
\end{tabular}

\section{NCT03738176}

Trial name or title

The efficacy of topical sesame oil vs topical triamcinolone on oral lichen planus and salivary level of oxidative stress biomarker

\begin{tabular}{ll}
\hline Methods & Parallel, single-blind, RCT \\
& Egypt \\
\hline Participants & Adults aged $18-80$ years affected by OLP \\
& $\begin{array}{l}\text { Inclusion criteria: clinically diagnosed of atrophic or erosive OLP (or both); no history of taking top- } \\
\text { ical corticosteroids for the last } 2 \text { months and systemic corticosteroid for the last } 6 \text { months; people } \\
\text { who agree to take medication and follow-up }\end{array}$ \\
& $\begin{array}{l}\text { Exclusion criteria: pregnant or breastfeeding; history of topical steroids during last } 2 \text { months and } \\
\text { systemic steroids during last } 6 \text { months; recent dental filling associated with the lesion or associat- } \\
\text { ed with recent drug administration; history of diabetes or hypertension or people with positive HCV } \\
\text { antibody or HBsAg }\end{array}$
\end{tabular}

Interventions

Group A: sesame oil $20 \mathrm{~g}+$ CMC $80 \mathrm{~g} 3$ times daily for 1 month

Group B: triamcinolone $140 \mathrm{~g}+\mathrm{Na}$ CMC $50 \mathrm{~g} 3$ times daily for 1 month

\begin{tabular}{ll}
\hline Outcomes & Primary outcomes: pain (VAS), clinical score (Thongprasom) \\
& Secondary outcome: salivary level of oxidative stress biomarker (thiobarbituric acid)
\end{tabular}

\begin{tabular}{ll}
\hline Starting date & December 2018 \\
\hline Contact information & Sponsor: Dr Mona Taha Mohammed MD, Cairo University; mona.taha@dentistry.cu.edu.eg \\
\hline Notes & \\
\hline
\end{tabular}

\section{NCT03793634}

\begin{tabular}{ll}
\hline Trial name or title & $\begin{array}{l}\text { Evaluation of topical chamomile vs topical triamcinolone acetonide in management of oral lichen } \\
\text { planus }\end{array}$ \\
\hline Methods & Parallel, double-blind, RCT \\
& Egypt
\end{tabular}


NCT03793634 (Continued)

Participants

Adults aged $30-80$ years with OLP

Inclusion criteria: symptomatic OLP; no history of taking corticosteroids for the last 6 months; people who agree to take medication; "medically free"

Exclusion criteria: oral lesions other than OLP; lichenoid reaction; pregnancy or breastfeeding; smokers

$\begin{array}{ll}\text { Interventions } & \text { Group A: topical chamomile } \\ \text { Group B: topical triamcinolone acetonide }\end{array}$

Outcomes Primary outcome: pain (numerical rating scale)

Secondary outcome: clinical sign scores (Thongprasom)

\begin{tabular}{ll}
\hline Starting date & Not reported \\
\hline Contact information & Esraa Nashat, Cairo University \\
\hline
\end{tabular}

Notes

CMC: carboxymethyl cellulose; ELISA: enzyme-linked immunosorbent assay; HBsAg: hepatitis B surface antigen; HCV: hepatitis C virus; IFNa: interferon- $\alpha$; OHIP: Oral Health Impact Profile; OLP: oral lichen planus; OLPClinROM: OLP Clinician Reported Outcome Measure; OLPSSM: Oral Lichen Planus Symptom Severity Measure; PUVA: psoralen and ultraviolet A; SF-36: 36-item Short Form; RCT: randomised controlled trial; TBA: thiobarbituric acid; UVB: ultraviolet B; VAS: visual analogue scale; WHO: World Health Organization.

\section{DATA AND ANALYSES}

Comparison 1. Corticosteroids versus placebo

\begin{tabular}{lllll}
\hline Outcome or subgroup title & $\begin{array}{l}\text { No. of } \\
\text { studies }\end{array}$ & $\begin{array}{l}\text { No. of } \\
\text { partici- } \\
\text { pants }\end{array}$ & Statistical method & Effect size \\
\hline 1 Pain score & 1 & & Mean Difference (IV, Fixed, 95\% Cl) & Totals not selected \\
\hline 1.1 Clobetasol vs placebo & 1 & Mean Difference (IV, Fixed, 95\% Cl) & $0.0[0.0,0.0]$ \\
\hline 2 Pain resolution & 2 & 72 & Risk Ratio (M-H, Fixed, 95\% Cl) & $1.91[1.08,3.36]$ \\
\hline 2.1 Flucinonide vs placebo & 1 & 40 & Risk Ratio (M-H, Fixed, 95\% Cl) & $2.17[1.03,4.55]$ \\
\hline 2.2 Clobetasol vs placebo & 1 & 32 & Risk Ratio (M-H, Fixed, 95\% Cl) & $1.6[0.67,3.84]$ \\
\hline 3 Clinical score & 1 & & Mean Difference (IV, Fixed, 95\% Cl) & Totals not selected \\
\hline 3.1 Clobetasol vs placebo & 1 & & Mean Difference (IV, Fixed, 95\% Cl) & $0.0[0.0,0.0]$ \\
\hline 4 Clinical resolution & 2 & 72 & Risk Ratio (M-H, Fixed, 95\% Cl) & $6.0[0.76,47.58]$ \\
\hline 4.1 Flucinonide vs placebo & 1 & 40 & Risk Ratio (M-H, Fixed, 95\% Cl) & $9.0[0.52,156.91]$ \\
\hline 4.2 Clobetasol vs placebo & 1 & 32 & Risk Ratio (M-H, Fixed, 95\% Cl) & $3.0[0.13,68.57]$ \\
\hline
\end{tabular}




\begin{tabular}{llllll}
\hline Outcome or subgroup title & $\begin{array}{l}\text { No. of } \\
\text { studies }\end{array}$ & $\begin{array}{l}\text { No. of } \\
\text { partici- } \\
\text { pants }\end{array}$ & Statistical method & Effect size \\
\hline 5 Adverse effects & 3 & 88 & Risk Ratio (M-H, Fixed, 95\% Cl) & $1.48[0.48,4.56]$ \\
\hline 5.1 Flucinonide vs placebo & 1 & 40 & Risk Ratio (M-H, Fixed, 95\% Cl) & $0.0[0.0,0.0]$ \\
\hline 5.2 Triamcinolone vs placebo & 1 & 16 & Risk Ratio (M-H, Fixed, 95\% Cl) & $1.29[0.37,4.53]$ \\
\hline 5.3 Clobetasol vs placebo & 1 & 32 & Risk Ratio (M-H, Fixed, 95\% Cl) & $2.0[0.20,19.91]$ \\
\hline
\end{tabular}

Analysis 1.1. Comparison 1 Corticosteroids versus placebo, Outcome 1 Pain score.

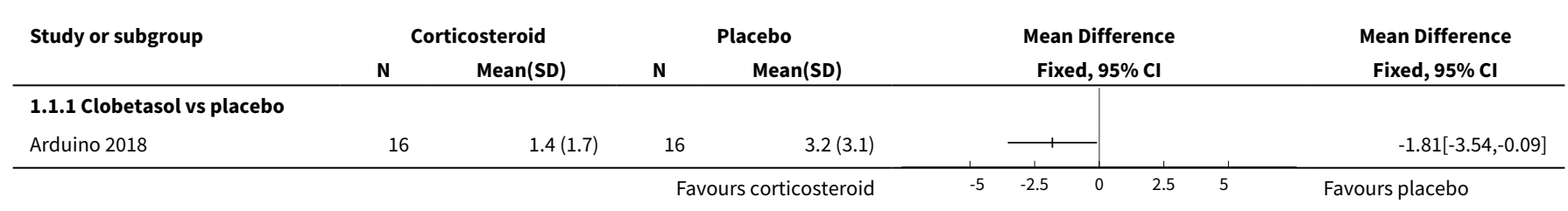

\section{Analysis 1.2. Comparison 1 Corticosteroids versus placebo, Outcome 2 Pain resolution.}

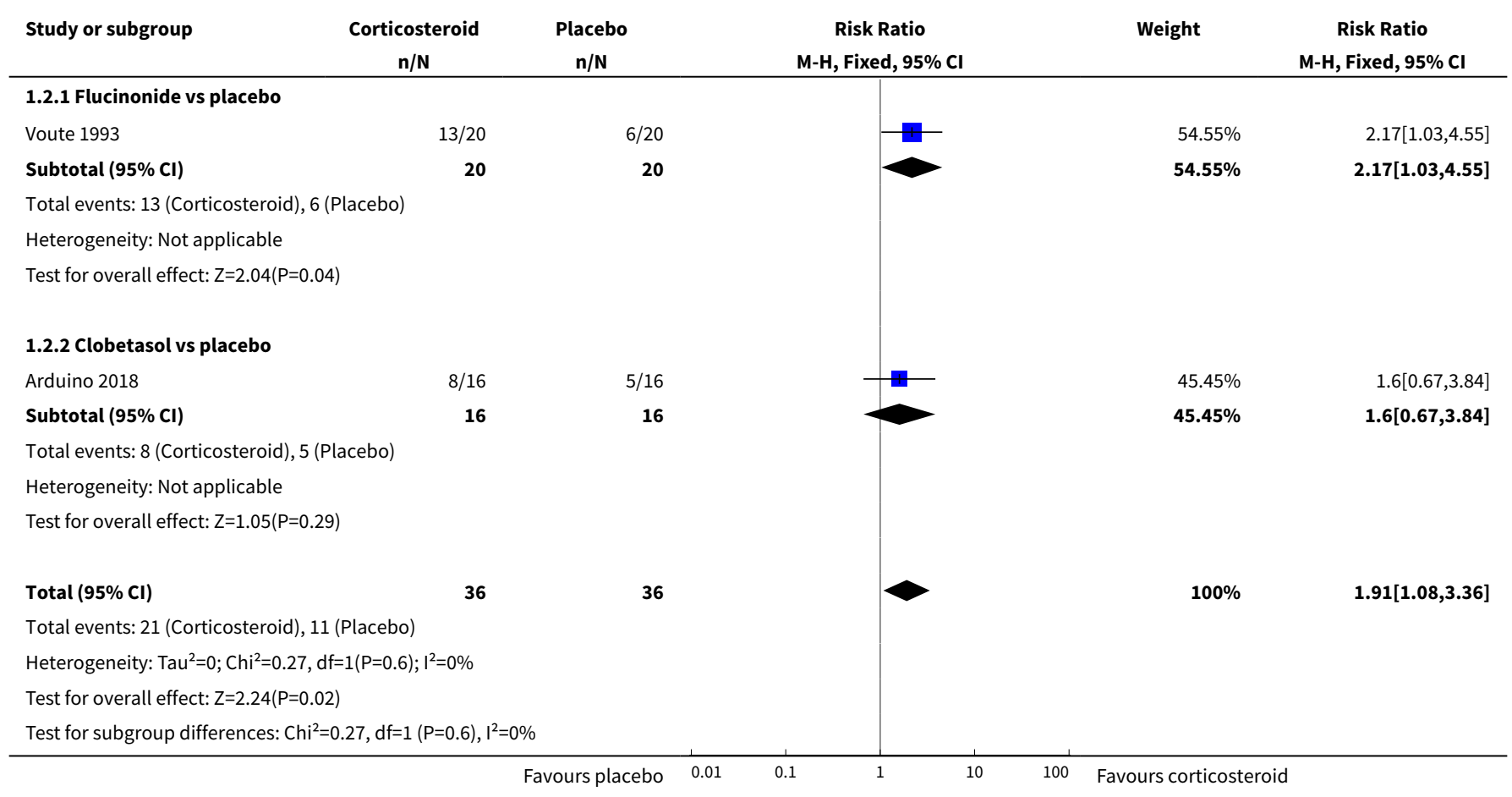


Analysis 1.3. Comparison 1 Corticosteroids versus placebo, Outcome 3 Clinical score.

\begin{tabular}{|c|c|c|c|c|c|c|c|}
\hline \multirow[t]{2}{*}{ Study or subgroup } & \multicolumn{2}{|c|}{ Corticosteroid } & \multicolumn{2}{|c|}{ Placebo } & \multirow{2}{*}{\multicolumn{2}{|c|}{$\begin{array}{c}\text { Mean Difference } \\
\text { Fixed, } 95 \% \mathrm{Cl}\end{array}$}} & \multirow{2}{*}{$\begin{array}{c}\text { Mean Difference } \\
\text { Fixed, } 95 \% \mathrm{Cl} \\
\end{array}$} \\
\hline & $\mathbf{N}$ & Mean(SD) & $\mathbf{N}$ & Mean(SD) & & & \\
\hline \multicolumn{8}{|c|}{ 1.3.1 Clobetasol vs placebo } \\
\hline Arduino 2018 & 16 & $2.7(0.9)$ & 16 & $3.1(0.6)$ & + & & $-0.37[-0.89,0.14]$ \\
\hline
\end{tabular}

\section{Analysis 1.4. Comparison 1 Corticosteroids versus placebo, Outcome 4 Clinical resolution.}

\begin{tabular}{|c|c|c|c|c|c|}
\hline Study or subgroup & $\begin{array}{c}\text { Corticosteroid } \\
n / N\end{array}$ & $\begin{array}{c}\text { Placebo } \\
n / N\end{array}$ & $\begin{array}{c}\text { Risk Ratio } \\
\text { M-H, Fixed, 95\% Cl }\end{array}$ & Weight & $\begin{array}{c}\text { Risk Ratio } \\
\text { M-H, Fixed, 95\% Cl }\end{array}$ \\
\hline \multicolumn{6}{|c|}{ 1.4.1 Flucinonide vs placebo } \\
\hline Voute 1993 & $4 / 20$ & $0 / 20$ & & $50 \%$ & $9[0.52,156.91]$ \\
\hline Subtotal $(95 \% \mathrm{Cl})$ & 20 & 20 & & $50 \%$ & $9[0.52,156.91]$ \\
\hline \multicolumn{6}{|c|}{ Total events: 4 (Corticosteroid), 0 (Placebo) } \\
\hline \multicolumn{6}{|c|}{ Heterogeneity: Not applicable } \\
\hline \multicolumn{6}{|c|}{ 1.4.2 Clobetasol vs placebo } \\
\hline Arduino 2018 & $1 / 16$ & $0 / 16$ & & $50 \%$ & $3[0.13,68.57]$ \\
\hline Subtotal $(95 \% \mathrm{CI})$ & 16 & 16 & & $50 \%$ & $3[0.13,68.57]$ \\
\hline \multicolumn{6}{|c|}{ Total events: 1 (Corticosteroid), 0 (Placebo) } \\
\hline \multicolumn{6}{|c|}{ Heterogeneity: Not applicable } \\
\hline \multicolumn{6}{|c|}{ Test for overall effect: $Z=0.69(P=0.49)$} \\
\hline Total $(95 \% \mathrm{Cl})$ & 36 & 36 & & $100 \%$ & $6[0.76,47.58]$ \\
\hline \multicolumn{6}{|c|}{ Total events: 5 (Corticosteroid), 0 (Placebo) } \\
\hline \multicolumn{6}{|c|}{ Heterogeneity: $\operatorname{Tau}^{2}=0 ; \mathrm{Chi}^{2}=0.27, \mathrm{df}=1(\mathrm{P}=0.61) ; \mathrm{I}^{2}=0 \%$} \\
\hline \multicolumn{6}{|c|}{ Test for overall effect: $Z=1.7(P=0.09)$} \\
\hline Test for subgroup dif & $.26, \mathrm{df}=1(\mathrm{P}=0.61)$, & & & & \\
\hline
\end{tabular}

\section{Analysis 1.5. Comparison 1 Corticosteroids versus placebo, Outcome 5 Adverse effects.}

\begin{tabular}{|c|c|c|c|c|c|}
\hline Study or subgroup & $\begin{array}{c}\text { Corticosteroid } \\
\mathrm{n} / \mathrm{N}\end{array}$ & \multirow[t]{2}{*}{$\begin{array}{c}\text { Placebo } \\
\mathbf{n} / \mathbf{N}\end{array}$} & $\begin{array}{c}\text { Risk Ratio } \\
\text { M-H, Fixed, 95\% Cl }\end{array}$ & Weight & \multirow[t]{2}{*}{$\begin{array}{c}\text { Risk Ratio } \\
\text { M-H, Fixed, 95\% Cl }\end{array}$} \\
\hline 1.5.1 Flucinonide vs & & & & & \\
\hline Voute 1993 & $0 / 20$ & $0 / 20$ & & & Not estimable \\
\hline Subtotal $(95 \% \mathrm{Cl})$ & 20 & 20 & & & Not estimable \\
\hline \multicolumn{6}{|c|}{ Total events: 0 (Corticosteroid), 0 (Placebo) } \\
\hline \multicolumn{6}{|c|}{ Heterogeneity: Not applicable } \\
\hline \multicolumn{6}{|c|}{ Test for overall effect: Not applicable } \\
\hline \multicolumn{6}{|c|}{ 1.5.2 Triamcinolone vs placebo } \\
\hline Siponen 2017 & $3 / 7$ & $3 / 9$ & - & $72.41 \%$ & $1.29[0.37,4.53]$ \\
\hline Subtotal $(95 \% \mathrm{Cl})$ & 7 & 9 & & $72.41 \%$ & $1.29[0.37,4.53]$ \\
\hline \multicolumn{6}{|c|}{ Total events: 3 (Corticosteroid), 3 (Placebo) } \\
\hline \multicolumn{6}{|c|}{ Heterogeneity: Not applicable } \\
\hline
\end{tabular}




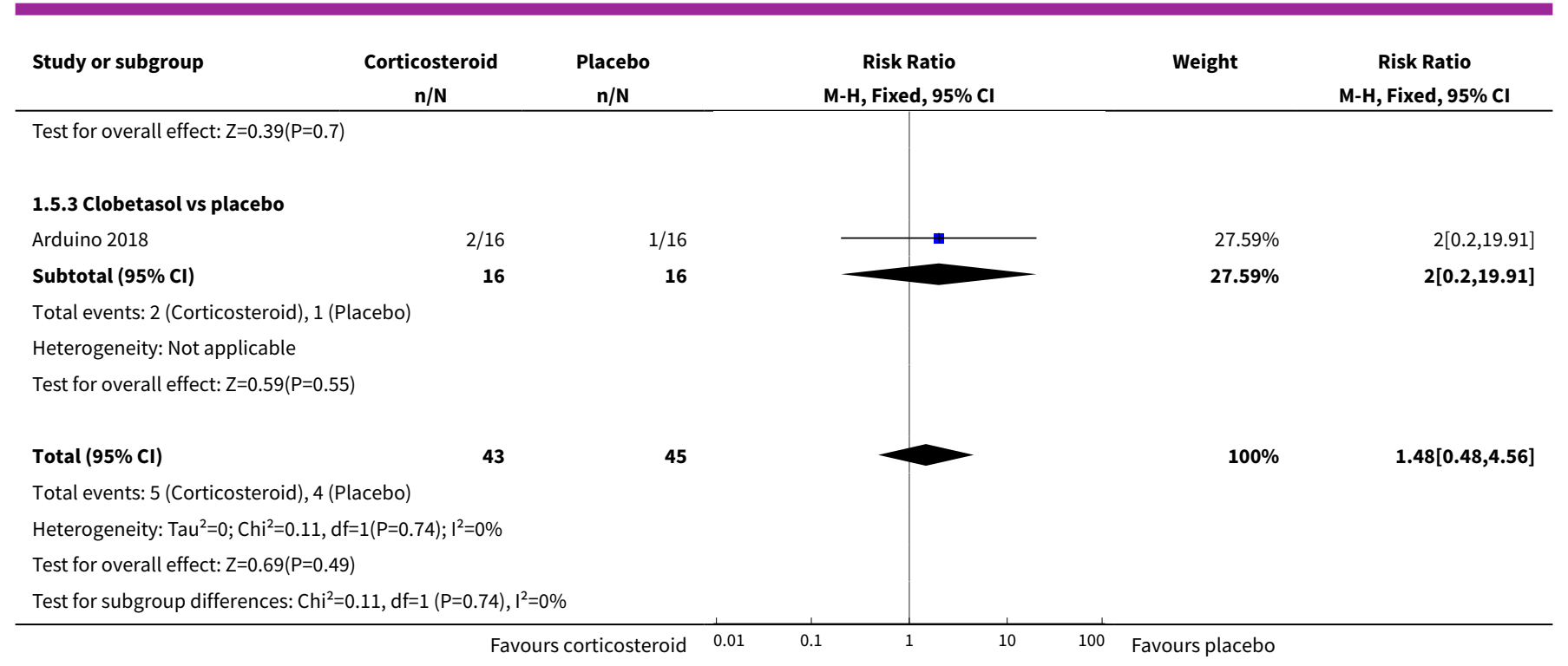

\section{Comparison 2. Corticosteroids versus calcineurin inhibitors}

\begin{tabular}{|c|c|c|c|c|}
\hline Outcome or subgroup title & $\begin{array}{l}\text { No. of } \\
\text { studies }\end{array}$ & $\begin{array}{l}\text { No. of } \\
\text { partici- } \\
\text { pants }\end{array}$ & Statistical method & Effect size \\
\hline 1 Pain score & 4 & & $\begin{array}{l}\text { Mean Difference (IV, Fixed, 95\% } \\
\mathrm{CI})\end{array}$ & Subtotals only \\
\hline 1.1 Clobetasol vs tacrolimus & 1 & 68 & $\begin{array}{l}\text { Mean Difference (IV, Fixed, 95\% } \\
\mathrm{CI})\end{array}$ & $0.08[-0.33,0.49]$ \\
\hline 1.2 Triamcinolone vs pimecrolimus & 2 & 70 & $\begin{array}{l}\text { Mean Difference (IV, Fixed, 95\% } \\
\mathrm{CI})\end{array}$ & $-0.05[-2.97,2.87]$ \\
\hline 1.3 Triamcinolone vs ciclosporin & 1 & 139 & $\begin{array}{l}\text { Mean Difference (IV, Fixed, 95\% } \\
\mathrm{CI})\end{array}$ & $-0.23[-1.02,0.56]$ \\
\hline 2 Pain resolution & 3 & & Risk Ratio (M-H, Fixed, 95\% Cl) & Subtotals only \\
\hline 2.1 Clobetasol vs ciclosporin & 1 & 39 & Risk Ratio (M-H, Fixed, 95\% Cl) & $2.11[0.76,5.86]$ \\
\hline 2.2 Clobetasol vs tacrolimus & 2 & 100 & Risk Ratio (M-H, Fixed, 95\% Cl) & $0.45[0.24,0.88]$ \\
\hline 3 Clinical score & 3 & & $\begin{array}{l}\text { Mean Difference (IV, Fixed, 95\% } \\
\mathrm{CI})\end{array}$ & Totals not selected \\
\hline 3.1 Clobetasol vs tacrolimus & 1 & & $\begin{array}{l}\text { Mean Difference (IV, Fixed, 95\% } \\
\mathrm{CI})\end{array}$ & $0.0[0.0,0.0]$ \\
\hline 3.2 Triamcinolone vs pimecrolimus & 2 & & $\begin{array}{l}\text { Mean Difference (IV, Fixed, 95\% } \\
\mathrm{CI})\end{array}$ & $0.0[0.0,0.0]$ \\
\hline 4 Clinical resolution & 4 & & Risk Ratio (M-H, Fixed, 95\% Cl) & Subtotals only \\
\hline 4.1 Clobetasol vs ciclosporin & 1 & 39 & Risk Ratio (M-H, Fixed, 95\% Cl) & $3.16[1.00,9.93]$ \\
\hline
\end{tabular}




\begin{tabular}{lllll}
\hline Outcome or subgroup title & $\begin{array}{l}\text { No. of } \\
\text { studies }\end{array}$ & $\begin{array}{l}\text { No. of } \\
\text { partici- } \\
\text { pants }\end{array}$ & Statistical method & Effect size \\
\hline 4.2 Clobetasol vs tacrolimus & 2 & 52 & Risk Ratio (M-H, Fixed, 95\% Cl) & $0.61[0.38,0.99]$ \\
\hline 4.3 Triamcinolone vs tacrolimus & 2 & 60 & Risk Ratio (M-H, Fixed, 95\% Cl) & $0.86[0.55,1.35]$ \\
\hline 5 Adverse effects & 7 & & Risk Ratio (M-H, Fixed, 95\% Cl) & Subtotals only \\
\hline 5.1 Clobetasol vs ciclosporin & 1 & 39 & Risk Ratio (M-H, Fixed, 95\% Cl) & $6.32[0.84,47.69]$ \\
\hline 5.2 Clobetasol vs tacrolimus & 2 & 100 & Risk Ratio (M-H, Fixed, 95\% Cl) & $0.05[0.00,0.83]$ \\
\hline 5.3 Triamcinolone vs ciclosporin & 1 & 139 & Risk Ratio (M-H, Fixed, 95\% Cl) & $0.15[0.05,0.49]$ \\
\hline 5.4 Triamcinolone vs pimecrolimus & 1 & 35 & Risk Ratio (M-H, Fixed, 95\% Cl) & $0.21[0.01,4.10]$ \\
\hline 5.5 Triamcinolone vs tacrolimus & 2 & 58 & Risk Ratio (M-H, Fixed, 95\% Cl) & $0.47[0.22,0.99]$ \\
\hline
\end{tabular}

Analysis 2.1. Comparison 2 Corticosteroids versus calcineurin inhibitors, Outcome 1 Pain score.

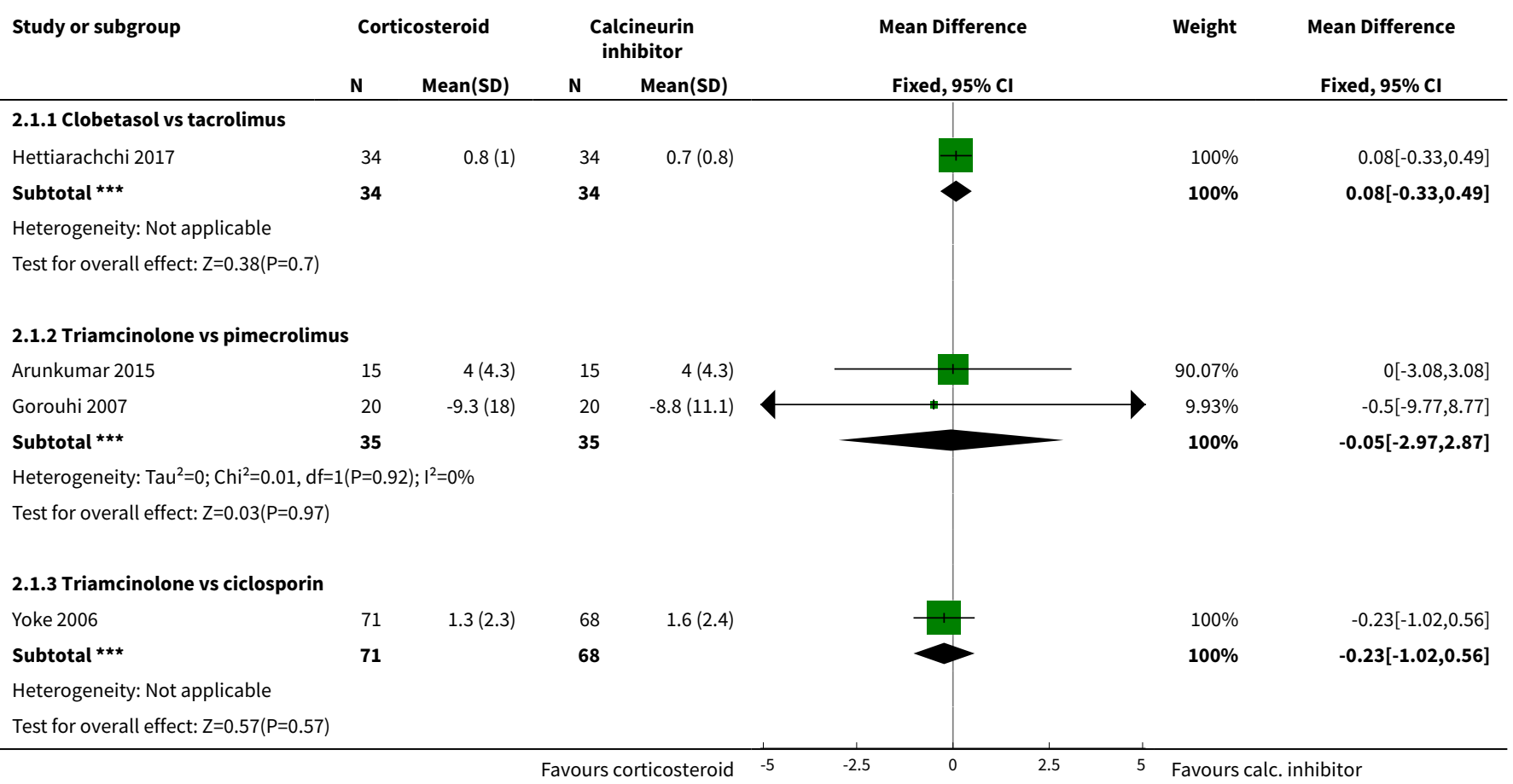


Analysis 2.2. Comparison 2 Corticosteroids versus calcineurin inhibitors, Outcome 2 Pain resolution.

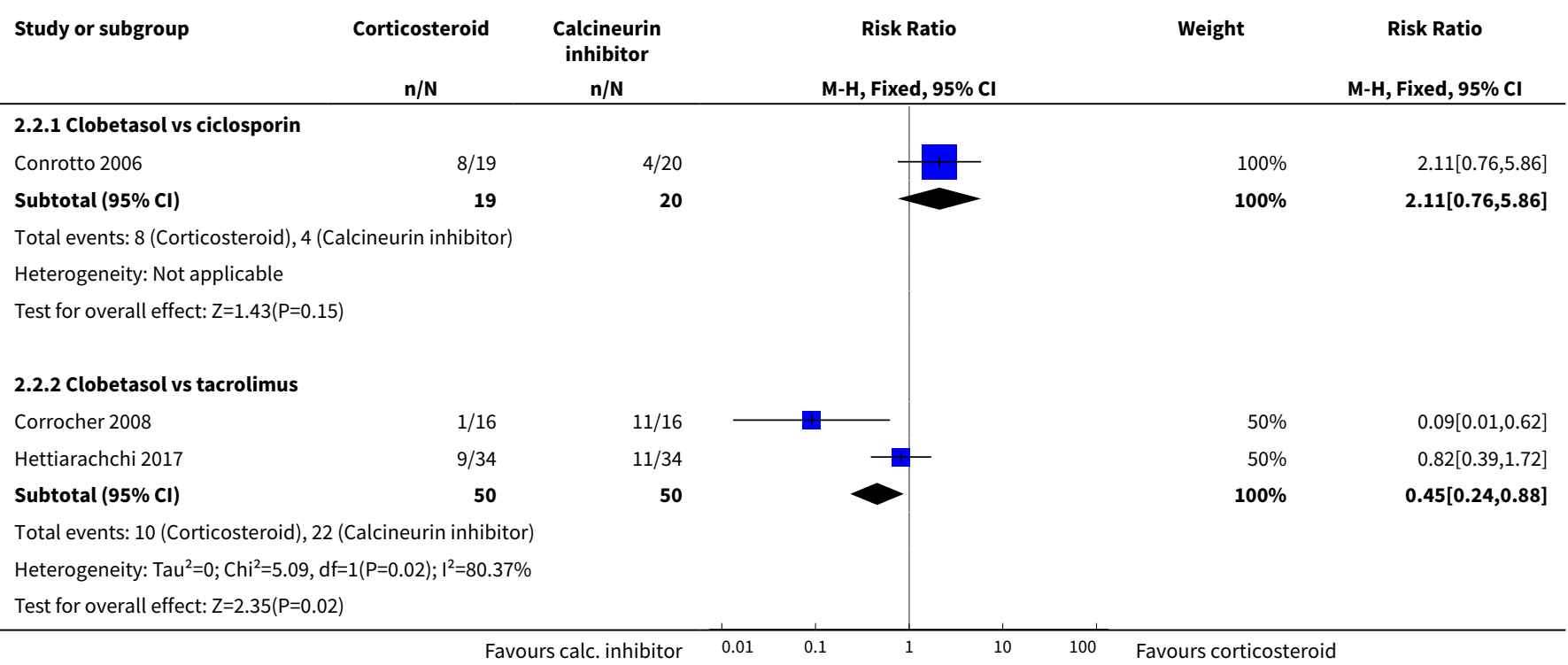

Analysis 2.3. Comparison 2 Corticosteroids versus calcineurin inhibitors, Outcome 3 Clinical score.

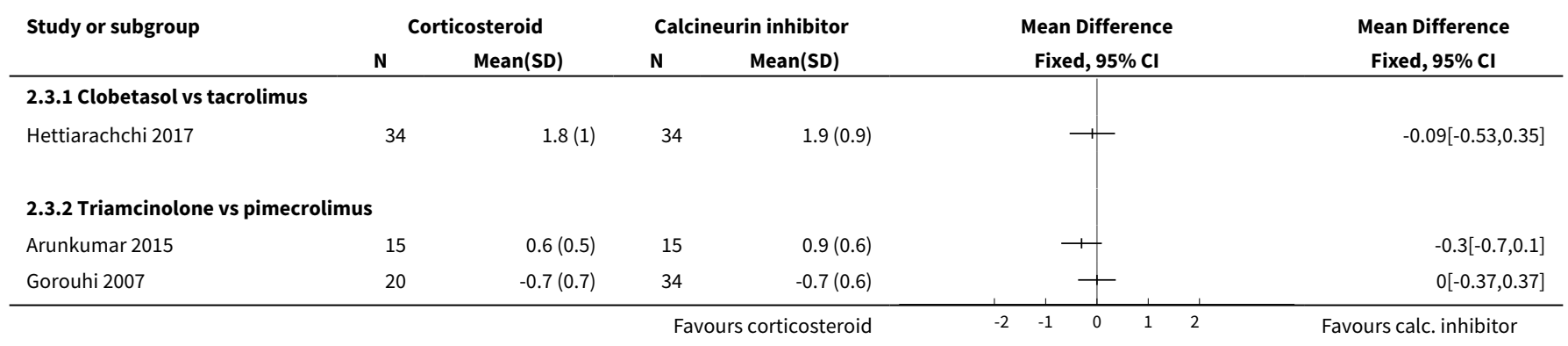

Analysis 2.4. Comparison 2 Corticosteroids versus calcineurin inhibitors, Outcome 4 Clinical resolution.

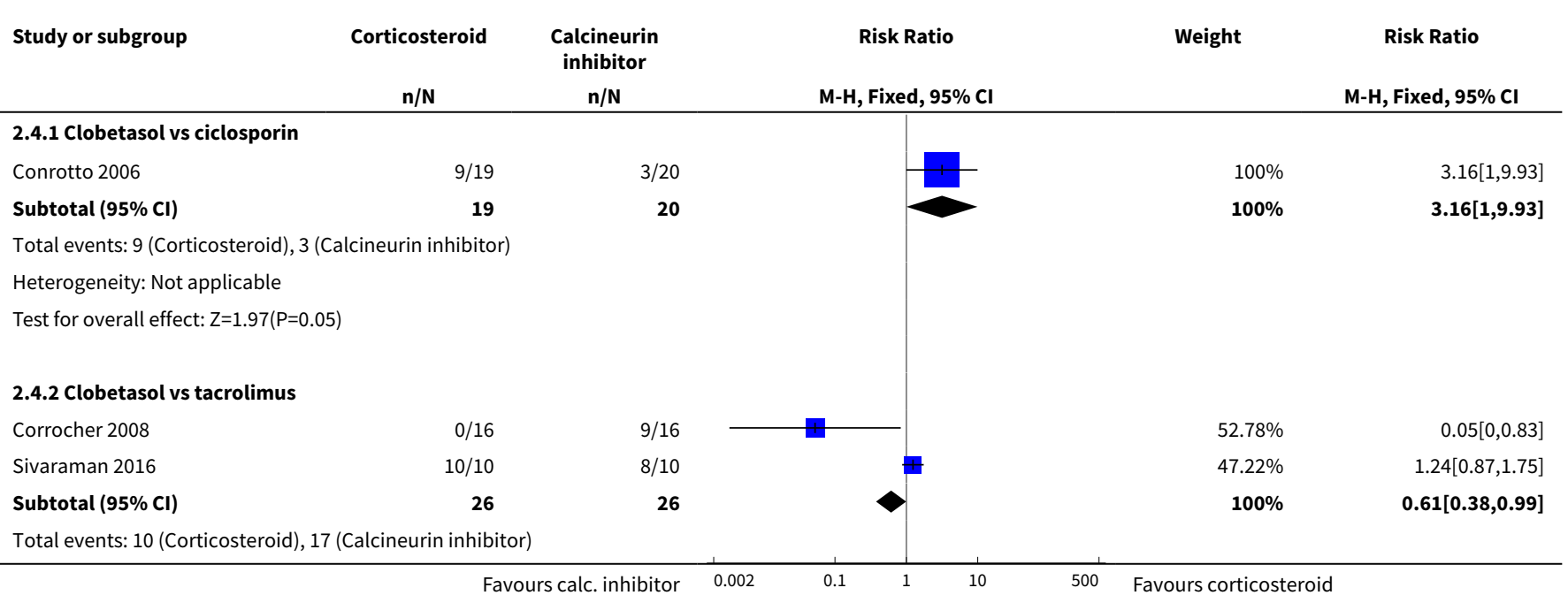




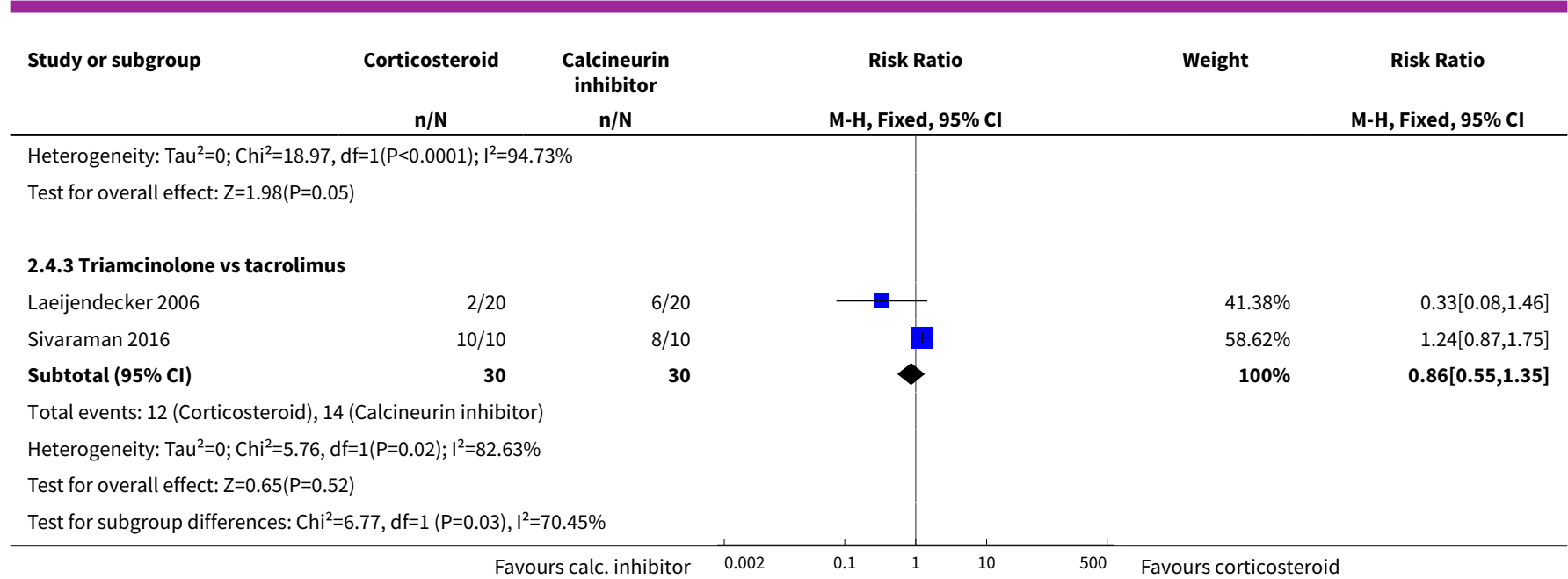

\section{Analysis 2.5. Comparison 2 Corticosteroids versus calcineurin inhibitors, Outcome 5 Adverse effects.}

\begin{tabular}{|c|c|c|c|c|c|}
\hline \multirow[t]{2}{*}{ Study or subgroup } & \multirow{2}{*}{$\begin{array}{l}\text { Corticosteroid } \\
n / N\end{array}$} & \multirow{2}{*}{$\begin{array}{c}\text { Calcineurin } \\
\text { inhibitor } \\
n / N\end{array}$} & Risk Ratio & \multirow[t]{2}{*}{ Weight } & \multirow{2}{*}{$\begin{array}{c}\text { Risk Ratio } \\
\text { M-H, Fixed, 95\% CI }\end{array}$} \\
\hline & & & M-H, Fixed, 95\% Cl & & \\
\hline \multicolumn{6}{|c|}{ 2.5.1 Clobetasol vs ciclosporin } \\
\hline Conrotto 2006 & $6 / 19$ & $1 / 20$ & & $100 \%$ & $6.32[0.84,47.69]$ \\
\hline Subtotal $(95 \% \mathrm{Cl})$ & 19 & 20 & & $100 \%$ & $6.32[0.84,47.69]$ \\
\hline \multicolumn{6}{|c|}{ Total events: 6 (Corticosteroid), 1 (Calcineurin inhibitor) } \\
\hline \multicolumn{6}{|c|}{ Heterogeneity: Not applicable } \\
\hline \multicolumn{6}{|c|}{ Test for overall effect: $Z=1.79(P=0.07)$} \\
\hline \multicolumn{6}{|c|}{ 2.5.2 Clobetasol vs tacrolimus } \\
\hline Corrocher 2008 & $0 / 16$ & $9 / 16$ & & $100 \%$ & $0.05[0,0.83]$ \\
\hline Hettiarachchi 2017 & $0 / 34$ & $0 / 34$ & & & Not estimable \\
\hline Subtotal $(95 \% \mathrm{Cl})$ & 50 & 50 & & $100 \%$ & $0.05[0,0.83]$ \\
\hline \multicolumn{6}{|c|}{ Heterogeneity: Not applicable } \\
\hline \multicolumn{6}{|c|}{ Test for overall effect: $Z=2.09(P=0.04)$} \\
\hline \multicolumn{6}{|c|}{ 2.5.3 Triamcinolone vs ciclosporin } \\
\hline Yoke 2006 & $3 / 71$ & $19 / 68$ & & $100 \%$ & $0.15[0.05,0.49]$ \\
\hline Subtotal $(95 \% \mathrm{Cl})$ & 71 & 68 & & $100 \%$ & $0.15[0.05,0.49]$ \\
\hline \multicolumn{6}{|c|}{ Total events: 3 (Corticosteroid), 19 (Calcineurin inhibitor) } \\
\hline \multicolumn{6}{|c|}{ Heterogeneity: Not applicable } \\
\hline \multicolumn{6}{|c|}{ Test for overall effect: $Z=3.16(P=0)$} \\
\hline \multicolumn{6}{|c|}{ 2.5.4 Triamcinolone vs pimecrolimus } \\
\hline Gorouhi 2007 & $0 / 17$ & $2 / 18$ & & $100 \%$ & $0.21[0.01,4.1]$ \\
\hline Subtotal $(95 \% \mathrm{CI})$ & 17 & 18 & & $100 \%$ & $0.21[0.01,4.1]$ \\
\hline \multicolumn{6}{|c|}{ Heterogeneity: Not applicable } \\
\hline \multicolumn{6}{|c|}{ Test for overall effect: $Z=1.03(P=0.3)$} \\
\hline \multicolumn{6}{|c|}{ 2.5.5 Triamcinolone vs tacrolimus } \\
\hline Laeijendecker 2006 & $3 / 20$ & $8 / 20$ & & $56.25 \%$ & $0.38[0.12,1.21]$ \\
\hline
\end{tabular}




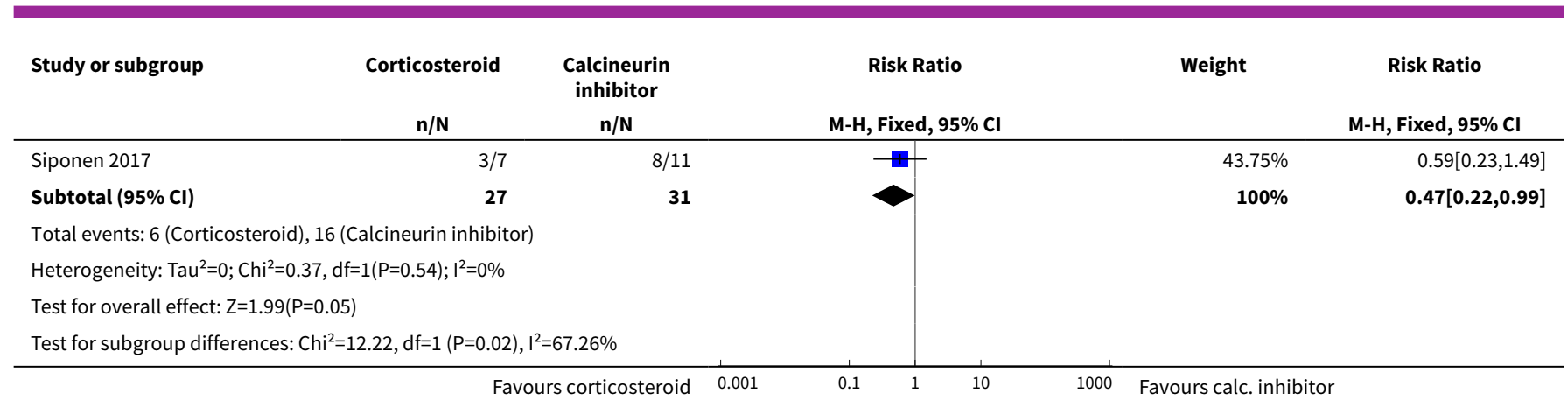

\section{Comparison 3. Corticosteroid A versus corticosteroid B}

\begin{tabular}{|c|c|c|c|c|}
\hline Outcome or subgroup title & $\begin{array}{l}\text { No. of } \\
\text { studies }\end{array}$ & $\begin{array}{l}\text { No. of } \\
\text { partici- } \\
\text { pants }\end{array}$ & Statistical method & Effect size \\
\hline 1 Pain score & 3 & & Mean Difference (IV, Fixed, 95\% CI) & $\begin{array}{l}\text { Totals not select- } \\
\text { ed }\end{array}$ \\
\hline $\begin{array}{l}1.1 \text { Clobetasol ointment }(0.025 \%) \text { vs clobe- } \\
\text { tasol ointment }(0.05 \%)\end{array}$ & 1 & & Mean Difference (IV, Fixed, 95\% CI) & $0.0[0.0,0.0]$ \\
\hline $\begin{array}{l}1.2 \text { Clobetasol ointment }(0.025 \%) \text { vs clobe- } \\
\text { tasol microspheres }(0.025 \%)\end{array}$ & 1 & & Mean Difference (IV, Fixed, 95\% CI) & $0.0[0.0,0.0]$ \\
\hline $\begin{array}{l}1.3 \text { Intralesional betamethasone }(1.4 \mathrm{mg}) \\
\text { vs intralesional triamcinolone acetonide } \\
\text { ( } 8 \mathrm{mg})\end{array}$ & 1 & & Mean Difference (IV, Fixed, 95\% CI) & $0.0[0.0,0.0]$ \\
\hline 2 Pain resolution & 1 & & Risk Ratio (M-H, Fixed, 95\% Cl) & $\begin{array}{l}\text { Totals not select- } \\
\text { ed }\end{array}$ \\
\hline $\begin{array}{l}2.1 \text { Betamethasone }(5 \mathrm{mg}) \text { vs triamci- } \\
\text { nolone paste }(0.1 \%)\end{array}$ & 1 & & Risk Ratio (M-H, Fixed, 95\% Cl) & $0.0[0.0,0.0]$ \\
\hline 3 Clinical score & 3 & & Mean Difference (IV, Fixed, 95\% CI) & $\begin{array}{l}\text { Totals not select- } \\
\text { ed }\end{array}$ \\
\hline $\begin{array}{l}3.1 \text { Clobetasol ointment }(0.025 \%) \text { vs clobe- } \\
\text { tasol ointment }(0.05 \%)\end{array}$ & 1 & & Mean Difference (IV, Fixed, 95\% CI) & $0.0[0.0,0.0]$ \\
\hline $\begin{array}{l}3.2 \text { Clobetasol }(0.025 \%) \text { ointment vs clobe- } \\
\text { tasol microspheres }(0.025 \%)\end{array}$ & 1 & & Mean Difference (IV, Fixed, 95\% CI) & $0.0[0.0,0.0]$ \\
\hline $\begin{array}{l}\text { 3.3 Betamethasone }(5 \mathrm{mg}) \text { vs triamci- } \\
\text { nolone }(0.1 \%)\end{array}$ & 1 & & Mean Difference (IV, Fixed, 95\% CI) & $0.0[0.0,0.0]$ \\
\hline 4 Clinical resolution & 5 & & Risk Ratio (M-H, Fixed, 95\% Cl) & Subtotals only \\
\hline $\begin{array}{l}4.1 \text { Clobetasol ointment }(0.025 \%) \text { vs clobe- } \\
\text { tasol ointment }(0.05 \%)\end{array}$ & 1 & 30 & Risk Ratio (M-H, Fixed, 95\% Cl) & $1.14[0.56,2.35]$ \\
\hline $\begin{array}{l}4.2 \text { Clobetasol ointment }(0.025 \%) \text { vs clobe- } \\
\text { tasol microspheres }(0.025 \%)\end{array}$ & 1 & 45 & Risk Ratio (M-H, Fixed, 95\% Cl) & $1.04[0.80,1.36]$ \\
\hline
\end{tabular}




\begin{tabular}{|c|c|c|c|c|}
\hline Outcome or subgroup title & $\begin{array}{l}\text { No. of } \\
\text { studies }\end{array}$ & $\begin{array}{l}\text { No. of } \\
\text { partici- } \\
\text { pants }\end{array}$ & Statistical method & Effect size \\
\hline $\begin{array}{l}4.3 \text { Clobetasol ointment }(0.05 \%) \text { vs triamci- } \\
\text { nolone }(0.1 \%) \text { ointment }\end{array}$ & 2 & 57 & Risk Ratio (M-H, Fixed, 95\% Cl) & $1.56[1.09,2.21]$ \\
\hline $\begin{array}{l}4.4 \text { Intralesional betamethasone }(1.4 \mathrm{mg}) \\
\text { vs intralesional triamcinolone acetonide ( } 8 \\
\mathrm{mg})\end{array}$ & 1 & 59 & Risk Ratio (M-H, Fixed, 95\% Cl) & $1.40[1.06,1.83]$ \\
\hline 5 Adverse effects & 5 & & Risk Ratio (M-H, Fixed, 95\% Cl) & $\begin{array}{l}\text { Totals not select- } \\
\text { ed }\end{array}$ \\
\hline $\begin{array}{l}5.1 \text { Clobetasol ointment }(0.025 \%) \text { vs clobe- } \\
\text { tasol ointment }(0.05 \%)\end{array}$ & 1 & & Risk Ratio (M-H, Fixed, 95\% Cl) & $0.0[0.0,0.0]$ \\
\hline $\begin{array}{l}5.2 \text { Clobetasol ointment }(0.025 \%) \text { vs clobe- } \\
\text { tasol microspheres }(0.025 \%)\end{array}$ & 1 & & Risk Ratio (M-H, Fixed, 95\% Cl) & $0.0[0.0,0.0]$ \\
\hline $\begin{array}{l}5.3 \text { Clobetasol ointment }(0.05 \%) \text { vs triamci- } \\
\text { nolone }(0.1 \%) \text { ointment }\end{array}$ & 1 & & Risk Ratio (M-H, Fixed, 95\% Cl) & $0.0[0.0,0.0]$ \\
\hline $\begin{array}{l}5.4 \text { Betamethasone }(5 \mathrm{mg}) \text { vs triamci- } \\
\text { nolone }(0.1 \%)\end{array}$ & 1 & & Risk Ratio (M-H, Fixed, 95\% Cl) & $0.0[0.0,0.0]$ \\
\hline $\begin{array}{l}5.5 \text { Intralesional betamethasone }(1.4 \mathrm{mg}) \\
\text { vs intralesional triamcinolone acetonide ( } 8 \\
\mathrm{mg})\end{array}$ & 1 & & Risk Ratio (M-H, Fixed, 95\% Cl) & $0.0[0.0,0.0]$ \\
\hline
\end{tabular}

Analysis 3.1. Comparison 3 Corticosteroid A versus corticosteroid B, Outcome 1 Pain score.

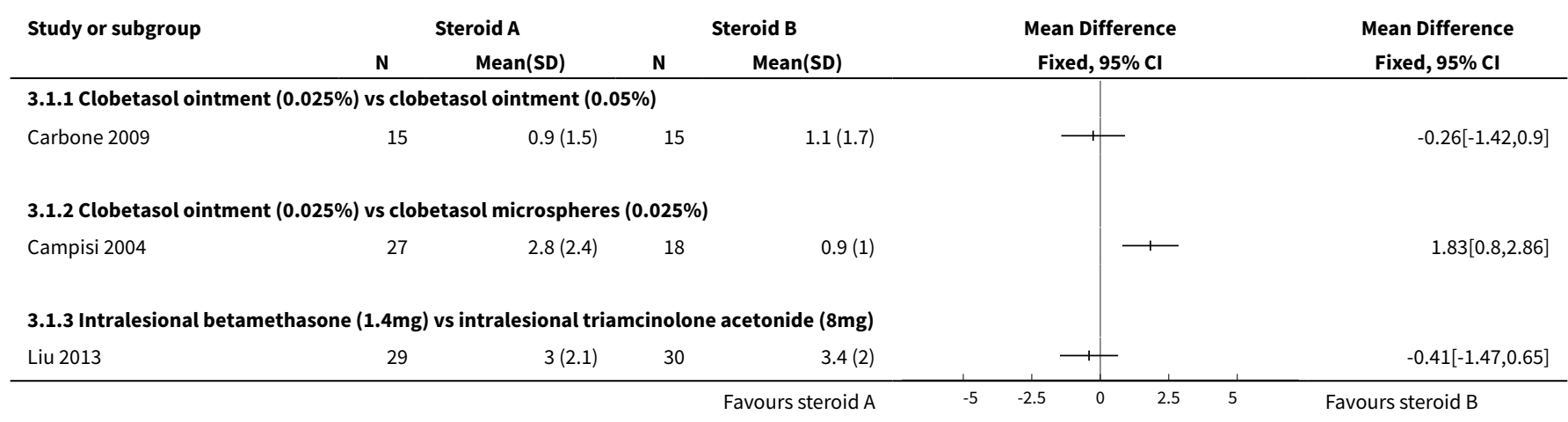

Analysis 3.2. Comparison 3 Corticosteroid A versus corticosteroid B, Outcome 2 Pain resolution.

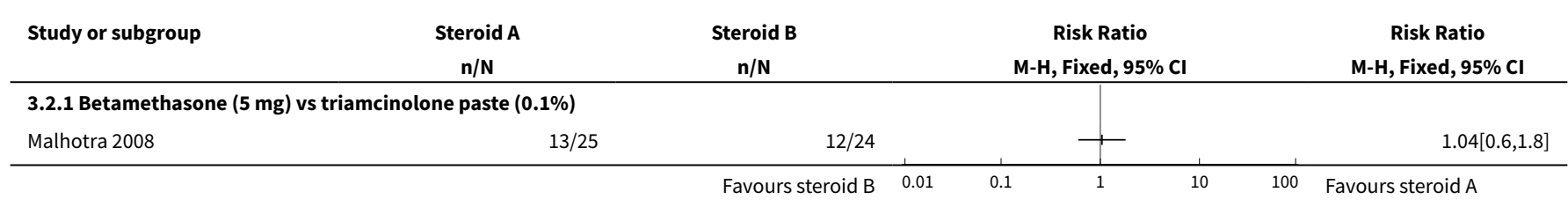


Analysis 3.3. Comparison 3 Corticosteroid A versus corticosteroid B, Outcome 3 Clinical score.

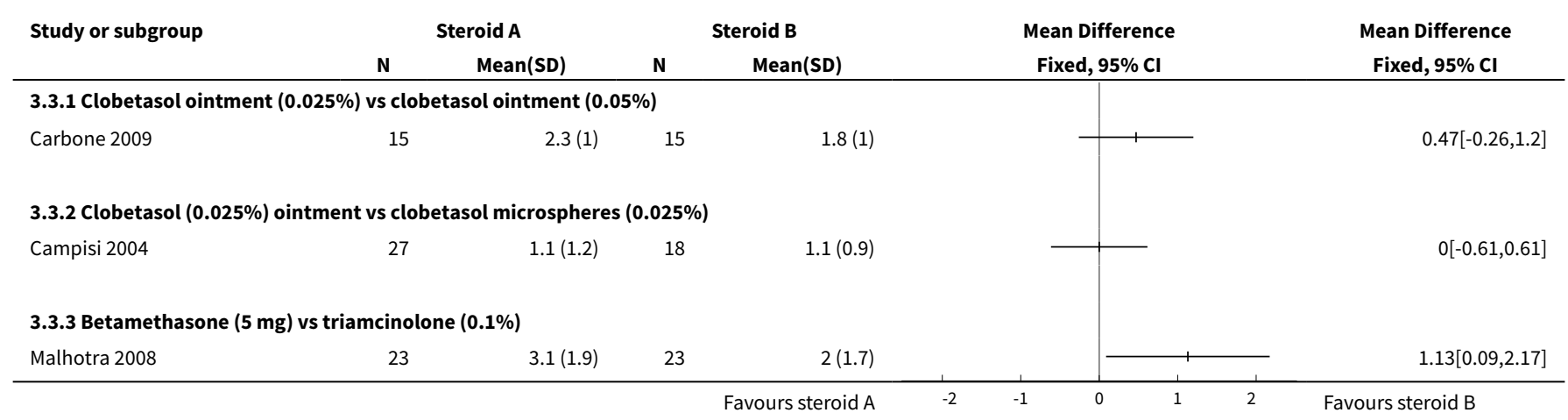

Analysis 3.4. Comparison 3 Corticosteroid A versus corticosteroid B, Outcome 4 Clinical resolution.

\begin{tabular}{|c|c|c|c|c|c|}
\hline Study or subgroup & $\begin{array}{c}\text { Steroid A } \\
\mathrm{n} / \mathrm{N}\end{array}$ & $\begin{array}{c}\text { Steroid B } \\
\mathrm{n} / \mathrm{N}\end{array}$ & $\begin{array}{c}\text { Risk Ratio } \\
\text { M-H, Fixed, } 95 \% \text { Cl }\end{array}$ & Weight & $\begin{array}{c}\text { Risk Ratio } \\
\text { M-H, Fixed, } 95 \% \mathrm{Cl}\end{array}$ \\
\hline \multicolumn{6}{|c|}{ 3.4.1 Clobetasol ointment $(0.025 \%)$ vs clobetasol ointment $(0.05 \%)$} \\
\hline Carbone 2009 & $8 / 15$ & $7 / 15$ & & $100 \%$ & $1.14[0.56,2.35]$ \\
\hline Subtotal $(95 \% \mathrm{Cl})$ & 15 & 15 & & $100 \%$ & $1.14[0.56,2.35]$ \\
\hline \multicolumn{6}{|c|}{ Total events: 8 (Steroid A), 7 (Steroid B) } \\
\hline \multicolumn{6}{|c|}{ Heterogeneity: Not applicable } \\
\hline \multicolumn{6}{|c|}{ Test for overall effect: $\mathrm{Z}=0.36(\mathrm{P}=0.72)$} \\
\hline \multicolumn{6}{|c|}{$\begin{array}{l}\text { 3.4.2 Clobetasol ointment }(0.025 \%) \text { vs clobetasol microspheres } \\
(0.025 \%)\end{array}$} \\
\hline Campisi 2004 & $24 / 28$ & $14 / 17$ & & $100 \%$ & $1.04[0.8,1.36]$ \\
\hline Subtotal $(95 \% \mathrm{Cl})$ & 28 & 17 & & $100 \%$ & $1.04[0.8,1.36]$ \\
\hline \multicolumn{6}{|c|}{ Total events: 24 (Steroid A), 14 (Steroid B) } \\
\hline \multicolumn{6}{|c|}{ Heterogeneity: Not applicable } \\
\hline \multicolumn{6}{|c|}{ Test for overall effect: $Z=0.29(P=0.77)$} \\
\hline \multicolumn{6}{|c|}{ 3.4.3 Clobetasol ointment $(0.05 \%)$ vs triamcinolone $(0.1 \%)$ ointment } \\
\hline Rodstrom 1994 & $12 / 17$ & $5 / 20$ & 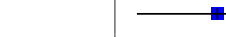 & $30.44 \%$ & $2.82[1.25,6.4]$ \\
\hline Sivaraman 2016 & $10 / 10$ & $10 / 10$ & & $69.56 \%$ & $1[0.83,1.2]$ \\
\hline Subtotal $(95 \% \mathrm{Cl})$ & 27 & 30 & & $100 \%$ & $1.56[1.09,2.21]$ \\
\hline \multicolumn{6}{|c|}{ Total events: 22 (Steroid A), 15 (Steroid B) } \\
\hline \multicolumn{6}{|c|}{ Heterogeneity: $\mathrm{Tau}^{2}=0 ; \mathrm{Chi}^{2}=24.55, \mathrm{df}=1(\mathrm{P}<0.0001) ; \mathrm{I}^{2}=95.93 \%$} \\
\hline \multicolumn{6}{|c|}{ Test for overall effect: $Z=2.47(P=0.01)$} \\
\hline \multicolumn{6}{|c|}{$\begin{array}{l}\text { 3.4.4 Intralesional betamethasone ( } 1.4 \mathrm{mg}) \text { vs intralesional triamci- } \\
\text { nolone acetonide }(8 \mathrm{mg})\end{array}$} \\
\hline Liu 2013 & $27 / 29$ & $20 / 30$ & & $100 \%$ & $1.4[1.06,1.83]$ \\
\hline Subtotal $(95 \% \mathrm{Cl})$ & 29 & 30 & & $100 \%$ & $1.4[1.06,1.83]$ \\
\hline \multicolumn{6}{|c|}{ Total events: 27 (Steroid A), 20 (Steroid B) } \\
\hline \multicolumn{6}{|c|}{ Heterogeneity: Not applicable } \\
\hline Test for overall effec & & & & & \\
\hline
\end{tabular}


Analysis 3.5. Comparison 3 Corticosteroid A versus corticosteroid B, Outcome 5 Adverse effects.

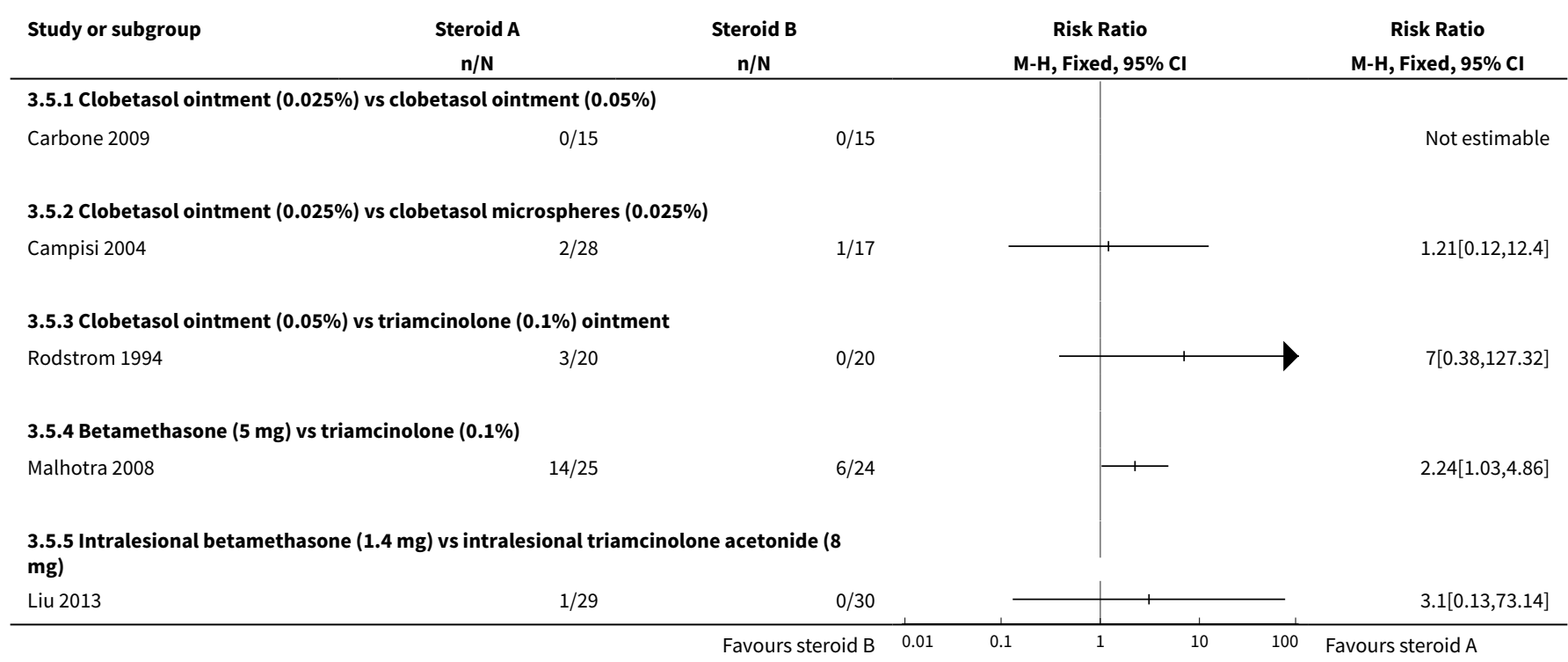

\section{Comparison 4. Corticosteroids versus other treatments}

\begin{tabular}{|c|c|c|c|c|}
\hline Outcome or subgroup title & $\begin{array}{l}\text { No. of } \\
\text { studies }\end{array}$ & $\begin{array}{l}\text { No. of } \\
\text { partici- } \\
\text { pants }\end{array}$ & Statistical method & Effect size \\
\hline 1 Pain score & 7 & & Mean Difference (IV, Fixed, 95\% CI) & Subtotals only \\
\hline $\begin{array}{l}1.1 \text { Triamcinolone vs curcumin } \\
\text { topical }\end{array}$ & 2 & 100 & Mean Difference (IV, Fixed, 95\% CI) & $-0.64[-1.19,-0.10]$ \\
\hline 1.2 Triamcinolone vs BCG-PSN & 1 & 53 & Mean Difference (IV, Fixed, 95\% CI) & $0.59[-0.15,1.33]$ \\
\hline $\begin{array}{l}1.3 \text { Clobetasol ointment } \\
(0.05 \%) \text { vs low-level laser ther- } \\
\text { apy }\end{array}$ & 1 & 42 & Mean Difference (IV, Fixed, 95\% CI) & $0.62[0.42,0.82]$ \\
\hline $\begin{array}{l}\text { 1.4 Dexamethasone ointment } \\
\text { vs amlexanox paste }\end{array}$ & 1 & 36 & Mean Difference (IV, Fixed, 95\% CI) & $0.05[-0.78,0.88]$ \\
\hline 1.5 Triamcinolone vs PDT & 1 & 20 & Mean Difference (IV, Fixed, 95\% CI) & $4.9[2.98,6.82]$ \\
\hline $\begin{array}{l}1.6 \text { Triamcinolone vs hyaluron- } \\
\text { ic acid }\end{array}$ & 1 & 40 & Mean Difference (IV, Fixed, 95\% CI) & $-0.12[-0.65,0.41]$ \\
\hline $\begin{array}{l}2 \text { Pain score (split-mouth } \\
\text { study) }\end{array}$ & 1 & & Mean Difference (Fixed, 95\% Cl) & Subtotals only \\
\hline $\begin{array}{l}2.1 \text { Triamcinolone vs cryother- } \\
\text { apy }\end{array}$ & 1 & & Mean Difference (Fixed, 95\% Cl) & $1.48[0.58,2.38]$ \\
\hline 3 Pain resolution & 1 & & Risk Ratio (M-H, Fixed, 95\% Cl) & Totals not selected \\
\hline
\end{tabular}




\begin{tabular}{|c|c|c|c|c|}
\hline Outcome or subgroup title & $\begin{array}{l}\text { No. of } \\
\text { studies }\end{array}$ & $\begin{array}{l}\text { No. of } \\
\text { partici- } \\
\text { pants }\end{array}$ & Statistical method & Effect size \\
\hline $\begin{array}{l}\text { 3.1 Dexamethasone ointment } \\
\text { vs amlexanox paste }\end{array}$ & 1 & & Risk Ratio (M-H, Fixed, 95\% Cl) & $0.0[0.0,0.0]$ \\
\hline 4 Clinical score & 8 & & Mean Difference (IV, Fixed, 95\% CI) & Totals not selected \\
\hline $\begin{array}{l}4.1 \text { Triamcinolone vs hyaluron- } \\
\text { ic acid }\end{array}$ & 1 & & Mean Difference (IV, Fixed, 95\% CI) & $0.0[0.0,0.0]$ \\
\hline $\begin{array}{l}4.2 \text { Triamcinolone vs curcumin } \\
\text { topical }\end{array}$ & 1 & & Mean Difference (IV, Fixed, 95\% CI) & $0.0[0.0,0.0]$ \\
\hline $\begin{array}{l}4.3 \text { Triamcinolone vs curcumin } \\
\text { topical }\end{array}$ & 1 & & Mean Difference (IV, Fixed, 95\% CI) & $0.0[0.0,0.0]$ \\
\hline 4.4 Triamcinolone vs BCG-PSN & 1 & & Mean Difference (IV, Fixed, 95\% Cl) & $0.0[0.0,0.0]$ \\
\hline $\begin{array}{l}\text { 4.5 Clobetasol ointment } \\
(0.05 \%) \text { vs low-level laser ther- } \\
\text { apy }\end{array}$ & 1 & & Mean Difference (IV, Fixed, 95\% CI) & $0.0[0.0,0.0]$ \\
\hline $\begin{array}{l}\text { 4.6 Dexamethasone ointment } \\
\text { vs amlexanox paste }\end{array}$ & 1 & & Mean Difference (IV, Fixed, 95\% CI) & $0.0[0.0,0.0]$ \\
\hline $\begin{array}{l}\text { 4.7 Dexamethasone mouth- } \\
\text { wash + nystatin vs PDT }\end{array}$ & 1 & & Mean Difference (IV, Fixed, 95\% CI) & $0.0[0.0,0.0]$ \\
\hline 4.8 Triamcinolone vs PDT & 1 & & Mean Difference (IV, Fixed, 95\% CI) & $0.0[0.0,0.0]$ \\
\hline $\begin{array}{l}5 \text { Clinical score (split-mouth } \\
\text { study) }\end{array}$ & 1 & & Mean Difference (Fixed, 95\% Cl) & $0.11[-0.46,0.68]$ \\
\hline $\begin{array}{l}5.1 \text { Triamcinolone vs cryother- } \\
\text { apy }\end{array}$ & 1 & & Mean Difference (Fixed, 95\% Cl) & $0.11[-0.46,0.68]$ \\
\hline 6 Clinical resolution & 4 & & Risk Ratio (M-H, Fixed, 95\% Cl) & Totals not selected \\
\hline $\begin{array}{l}6.1 \text { Triamcinolone paste vs } \\
\text { curcumin paste }\end{array}$ & 1 & & Risk Ratio (M-H, Fixed, 95\% Cl) & $0.0[0.0,0.0]$ \\
\hline $\begin{array}{l}\text { 6.2 Clobetasol ointment } \\
(0.05 \%) \text { vs low-level laser ther- } \\
\text { apy }\end{array}$ & 1 & & Risk Ratio (M-H, Fixed, 95\% Cl) & $0.0[0.0,0.0]$ \\
\hline $\begin{array}{l}\text { 6.3 Dexamethasone ointment } \\
\text { vs amlexanox paste }\end{array}$ & 1 & & Risk Ratio (M-H, Fixed, 95\% Cl) & $0.0[0.0,0.0]$ \\
\hline $\begin{array}{l}\text { 6.4 Dexamethasone mouth- } \\
\text { wash + nystatin vs PDT }\end{array}$ & 1 & & Risk Ratio (M-H, Fixed, 95\% Cl) & $0.0[0.0,0.0]$ \\
\hline $\begin{array}{l}7 \text { Clinical Resolution (split- } \\
\text { mouth study) }\end{array}$ & 1 & 26 & Odds Ratio (Fixed, 95\% Cl) & $0.64[0.17,2.44]$ \\
\hline 8 Adverse effects & 4 & & Risk Ratio (M-H, Fixed, 95\% Cl) & Totals not selected \\
\hline
\end{tabular}




\begin{tabular}{lllll}
\hline Outcome or subgroup title & $\begin{array}{l}\text { No. of } \\
\text { studies }\end{array}$ & $\begin{array}{l}\text { No. of } \\
\text { partici- } \\
\text { pants }\end{array}$ & Statistical method & Effect size \\
\hline $\begin{array}{l}8.1 \text { Triamcinolone paste vs } \\
\text { curcumin paste }\end{array}$ & 1 & & Risk Ratio (M-H, Fixed, 95\% Cl) & $0.0[0.0,0.0]$ \\
\hline $\begin{array}{l}\text { 8.2 Triamcinolone vs BCG-PSN } \\
\text { 8.3 Clobetasol ointment }\end{array}$ & 1 & Risk Ratio (M-H, Fixed, 95\% Cl) & $0.0[0.0,0.0]$ \\
$\begin{array}{l}0.05 \%) \text { vs low-level laser ther- } \\
\text { apy }\end{array}$ & 1 & Risk Ratio (M-H, Fixed, 95\% Cl) & $0.0[0.0,0.0]$ \\
\hline $\begin{array}{l}\text { 8.4 Dexamethasone ointment } \\
\text { vs amlexanox paste }\end{array}$ & 1 & & Risk Ratio (M-H, Fixed, 95\% Cl) & \\
\hline $\begin{array}{l}\text { 9 Adverse events (split-mouth } \\
\text { study) }\end{array}$ & 1 & 30 & Odds Ratio (Fixed, 95\% Cl) & $0.0[0.0,0.0]$ \\
\hline
\end{tabular}

\section{Analysis 4.1. Comparison 4 Corticosteroids versus other treatments, Outcome 1 Pain score.}

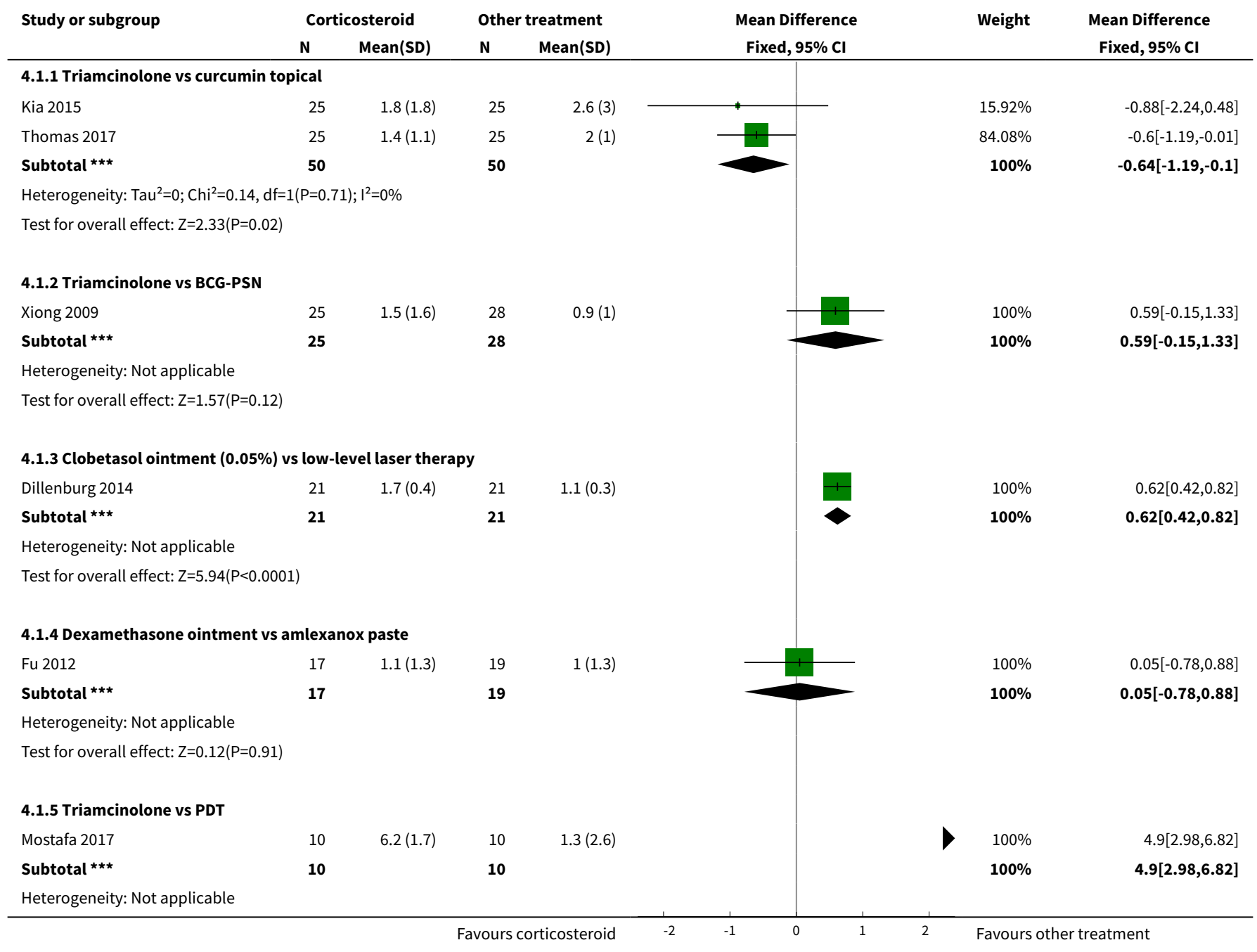




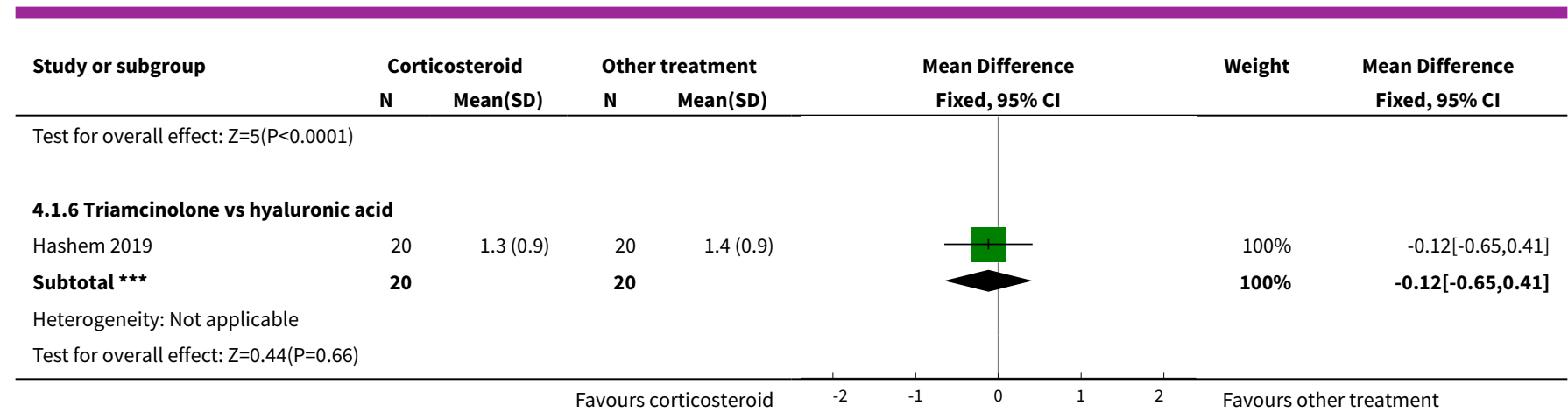

Analysis 4.2. Comparison 4 Corticosteroids versus other treatments, Outcome 2 Pain score (split-mouth study).

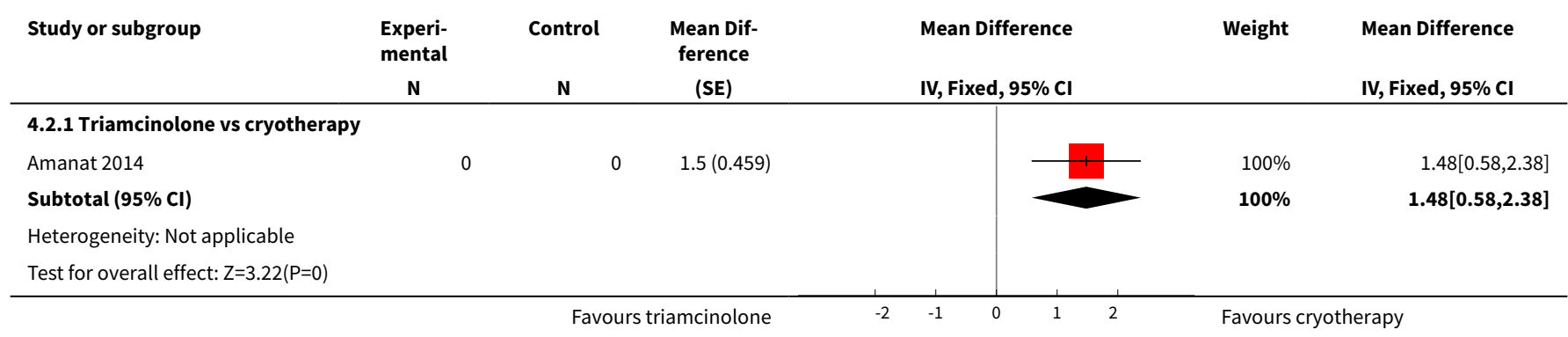

Analysis 4.3. Comparison 4 Corticosteroids versus other treatments, Outcome 3 Pain resolution.

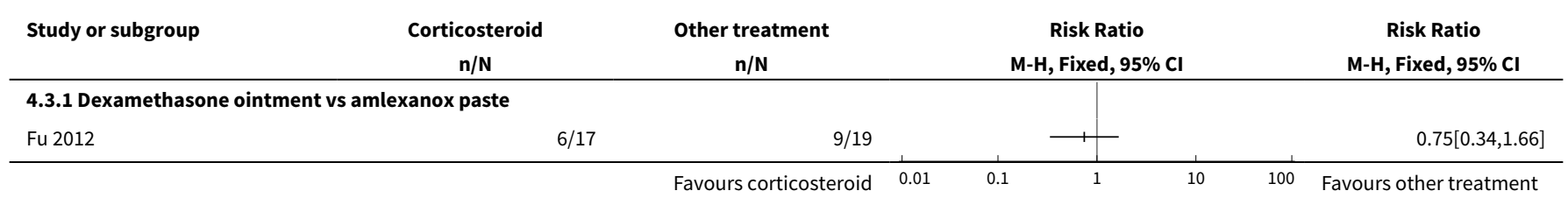

Analysis 4.4. Comparison 4 Corticosteroids versus other treatments, Outcome 4 Clinical score.

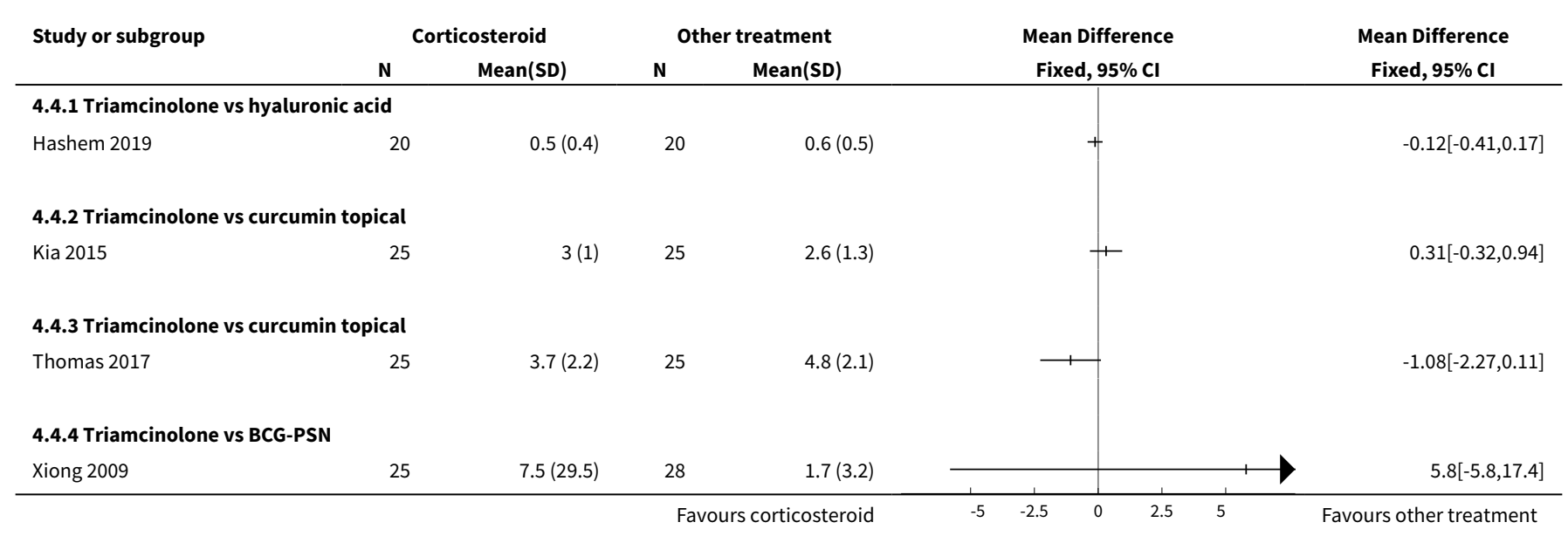




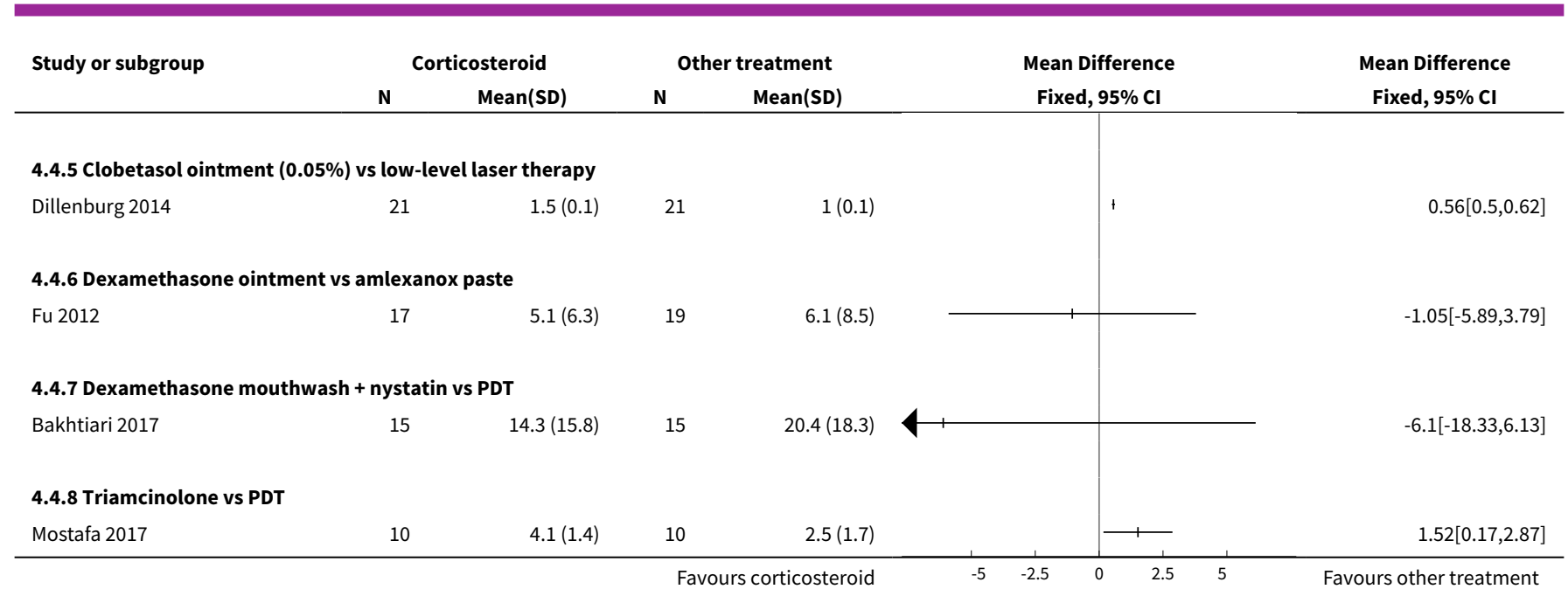

Analysis 4.5. Comparison 4 Corticosteroids versus other treatments, Outcome 5 Clinical score (split-mouth study).

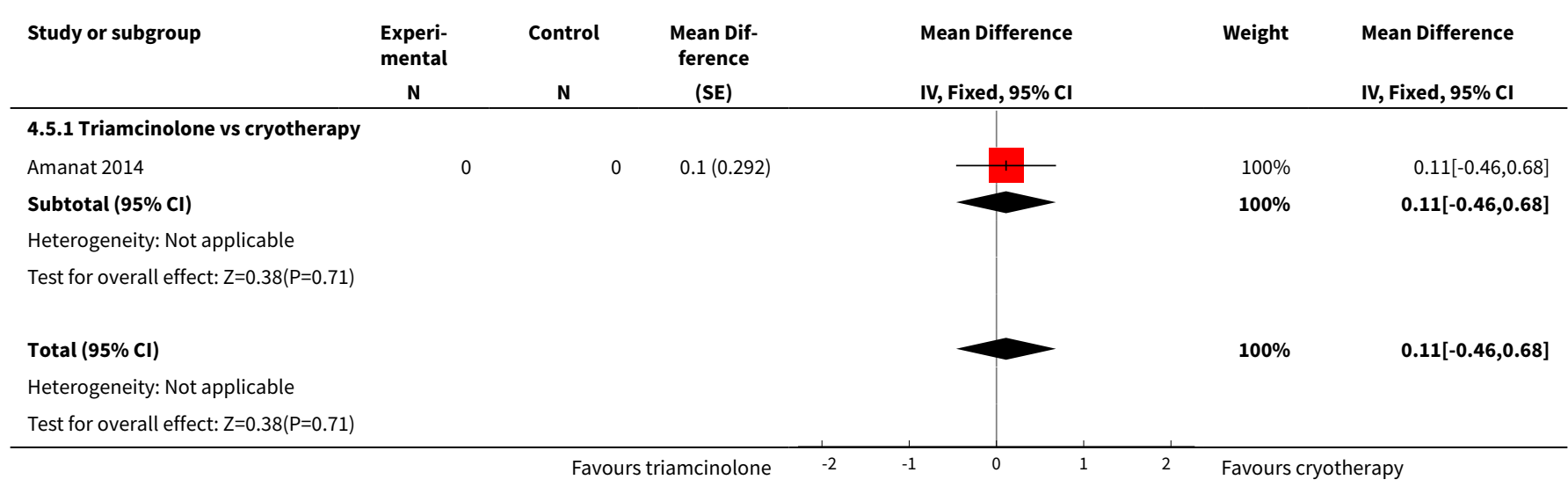

Analysis 4.6. Comparison 4 Corticosteroids versus other treatments, Outcome 6 Clinical resolution.

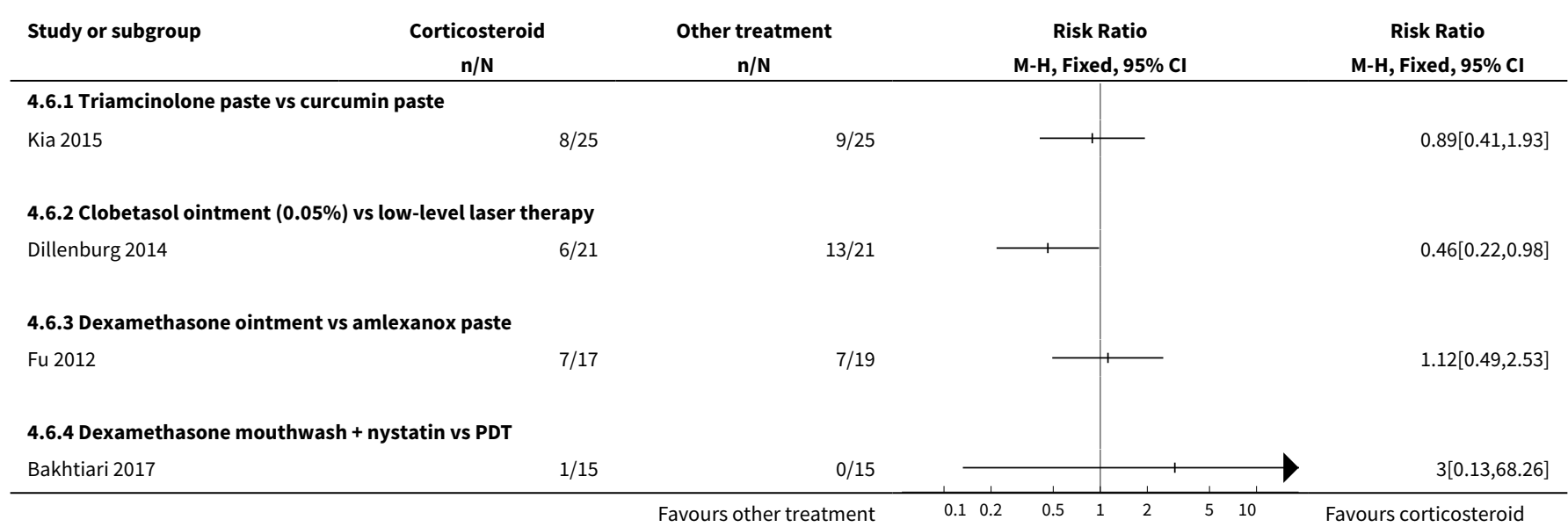


Analysis 4.7. Comparison 4 Corticosteroids versus other treatments, Outcome 7 Clinical Resolution (split-mouth study).

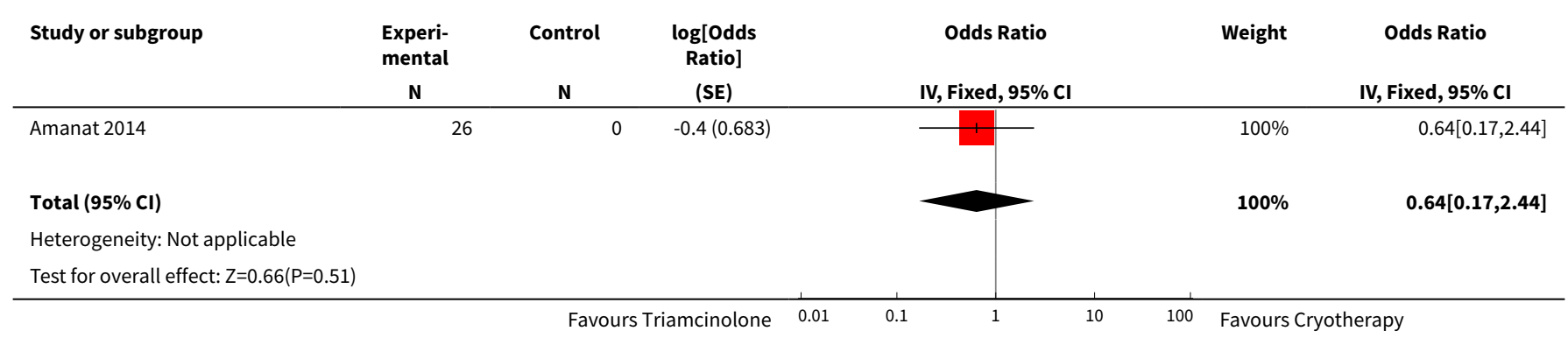

Analysis 4.8. Comparison 4 Corticosteroids versus other treatments, Outcome 8 Adverse effects.

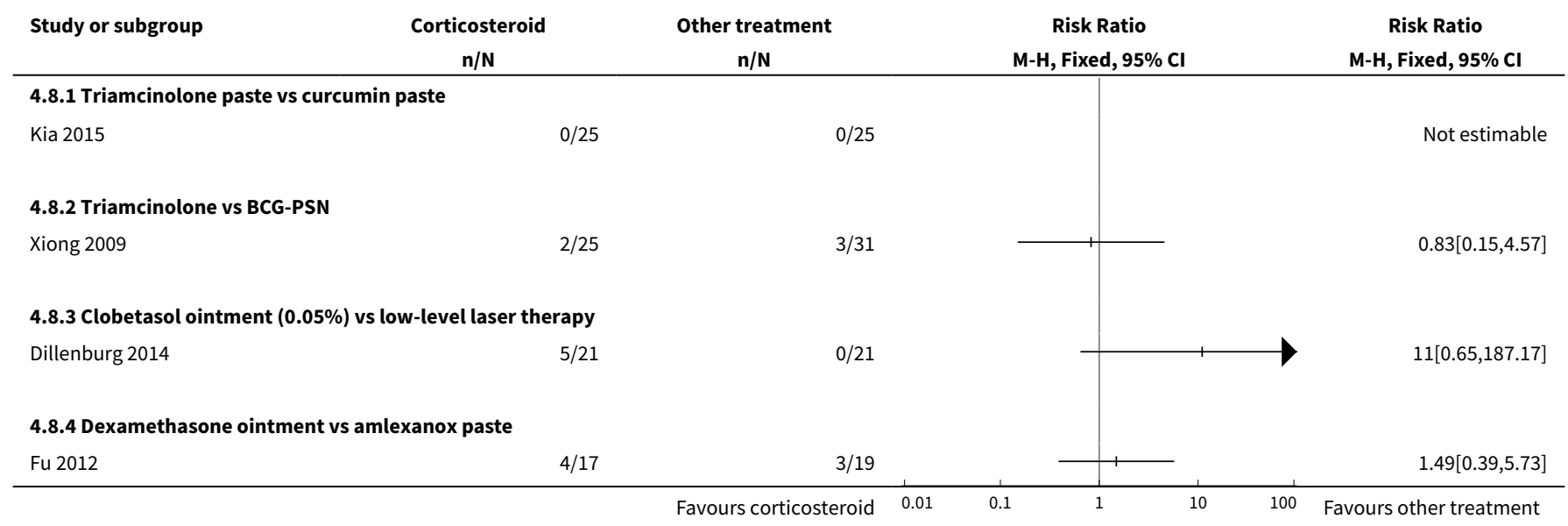

Analysis 4.9. Comparison 4 Corticosteroids versus other treatments, Outcome 9 Adverse events (split-mouth study).

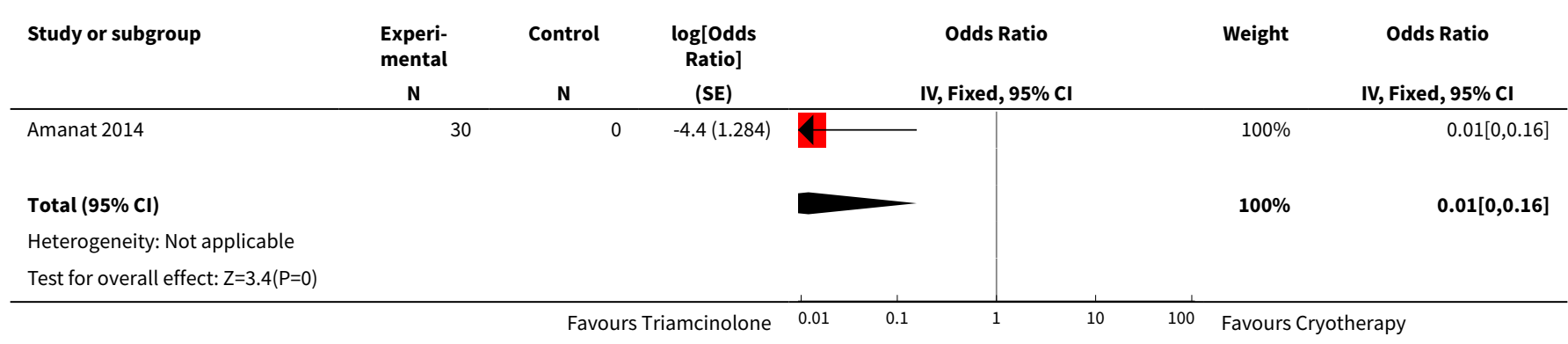


Comparison 5. Adjunctive treatment to corticosteroids

\begin{tabular}{|c|c|c|c|c|}
\hline Outcome or subgroup title & $\begin{array}{l}\text { No. of } \\
\text { studies }\end{array}$ & $\begin{array}{l}\text { No. of } \\
\text { partici- } \\
\text { pants }\end{array}$ & Statistical method & Effect size \\
\hline 1 Pain (mean score) & 3 & & Mean Difference (IV, Fixed, 95\% CI) & $\begin{array}{l}\text { Totals not select- } \\
\text { ed }\end{array}$ \\
\hline $\begin{array}{l}\text { 1.1 Clobetasol + miconazole vs clobeta- } \\
\text { sol + placebo }\end{array}$ & 1 & & Mean Difference (IV, Fixed, 95\% CI) & $0.0[0.0,0.0]$ \\
\hline $\begin{array}{l}\text { 1.2 Dexamethasone }+ \text { nystatin }+ \text { cur- } \\
\text { cumin vs dexamethasone }+ \text { nystatin }+ \\
\text { placebo }\end{array}$ & 1 & & Mean Difference (IV, Fixed, 95\% CI) & $0.0[0.0,0.0]$ \\
\hline $\begin{array}{l}\text { 1.3 Triamcinolone vs triamcinolone + } \\
\text { glucosamine sulphate }\end{array}$ & 1 & & Mean Difference (IV, Fixed, 95\% CI) & $0.0[0.0,0.0]$ \\
\hline 2 Clinical score & 3 & & Mean Difference (IV, Fixed, 95\% CI) & $\begin{array}{l}\text { Totals not select- } \\
\text { ed }\end{array}$ \\
\hline $\begin{array}{l}2.1 \text { Clobetasol + miconazole vs clobeta- } \\
\text { sol + placebo }\end{array}$ & 1 & & Mean Difference (IV, Fixed, 95\% CI) & $0.0[0.0,0.0]$ \\
\hline $\begin{array}{l}\text { 2.2 Dexamethasone }+ \text { nystatin }+ \text { cur- } \\
\text { cumin vs dexamethasone }+ \text { nystatin }+ \\
\text { placebo }\end{array}$ & 1 & & Mean Difference (IV, Fixed, 95\% CI) & $0.0[0.0,0.0]$ \\
\hline $\begin{array}{l}2.3 \text { Triamcinolone vs triamcinolone + } \\
\text { glucosamine sulphate }\end{array}$ & 1 & & Mean Difference (IV, Fixed, 95\% CI) & $0.0[0.0,0.0]$ \\
\hline 3 Clinical resolution & 2 & & Risk Ratio (M-H, Fixed, 95\% Cl) & $\begin{array}{l}\text { Totals not select- } \\
\text { ed }\end{array}$ \\
\hline $\begin{array}{l}\text { 3.1 Dexamethasone + mycostatin vs } \\
\text { dexamethasone alone }\end{array}$ & 1 & & Risk Ratio (M-H, Fixed, 95\% Cl) & $0.0[0.0,0.0]$ \\
\hline $\begin{array}{l}\text { 3.2 Dexamethasone + nystatin }+ \text { cur- } \\
\text { cumin vs dexamethasone }+ \text { nystatin }+ \\
\text { placebo }\end{array}$ & 1 & & Risk Ratio (M-H, Fixed, 95\% Cl) & $0.0[0.0,0.0]$ \\
\hline 4 Adverse effects & 2 & & Risk Ratio (M-H, Fixed, 95\% Cl) & $\begin{array}{l}\text { Totals not select- } \\
\text { ed }\end{array}$ \\
\hline $\begin{array}{l}4.1 \text { Clobetasol + miconazole vs clobeta- } \\
\text { sol + placebo }\end{array}$ & 1 & & Risk Ratio (M-H, Fixed, 95\% Cl) & $0.0[0.0,0.0]$ \\
\hline $\begin{array}{l}\text { 4.2 Dexamethasone + nystatin + cur- } \\
\text { cumin vs dexamethasone + nystatin }+ \\
\text { placebo }\end{array}$ & 1 & & Risk Ratio (M-H, Fixed, 95\% Cl) & $0.0[0.0,0.0]$ \\
\hline
\end{tabular}


Analysis 5.1. Comparison 5 Adjunctive treatment to corticosteroids, Outcome 1 Pain (mean score).

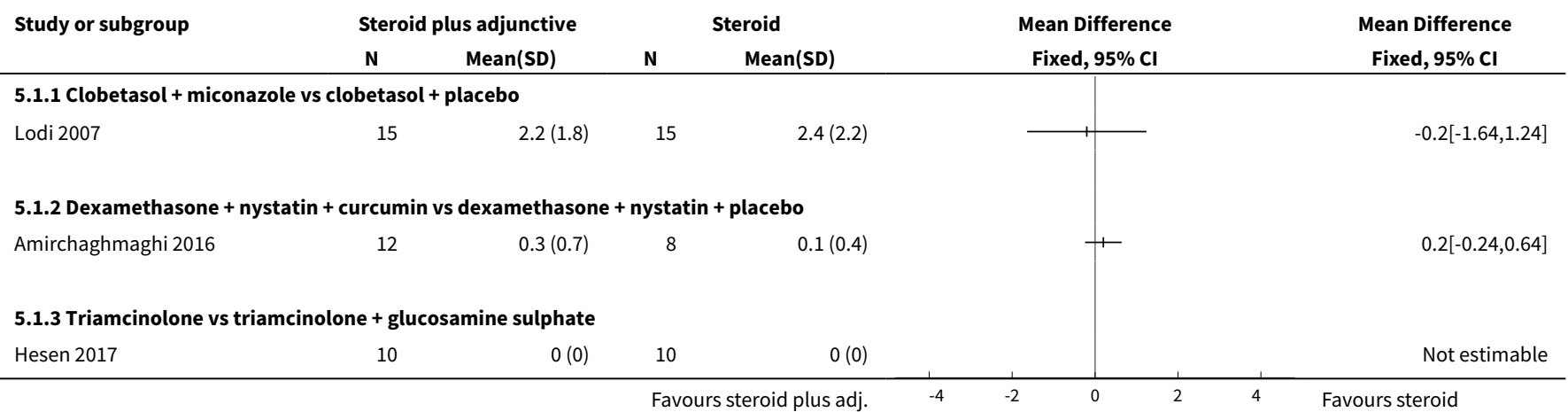

Analysis 5.2. Comparison 5 Adjunctive treatment to corticosteroids, Outcome 2 Clinical score.

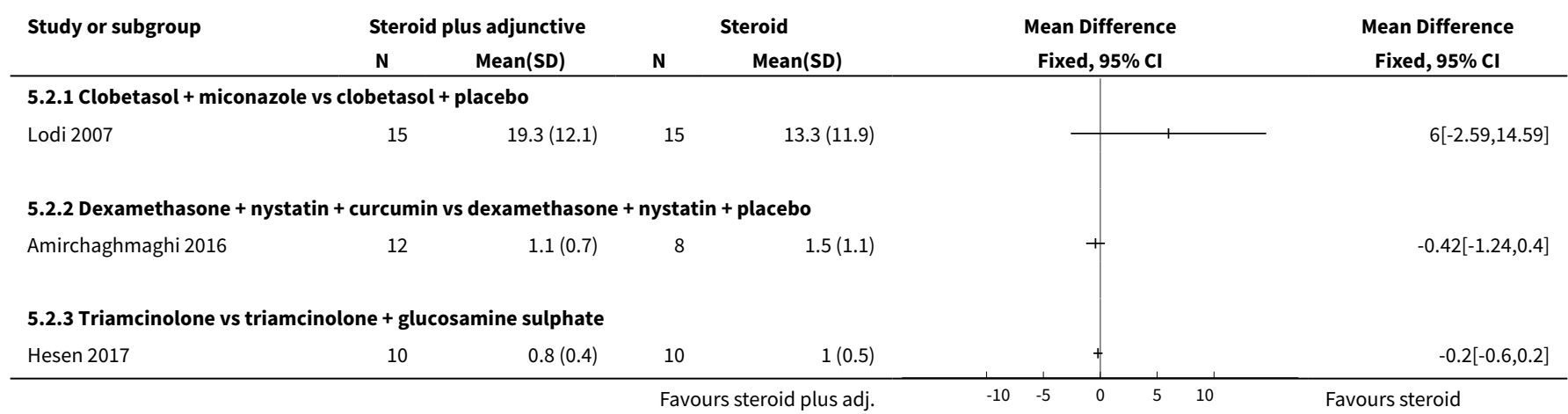

\section{Analysis 5.3. Comparison 5 Adjunctive treatment to corticosteroids, Outcome 3 Clinical resolution.}

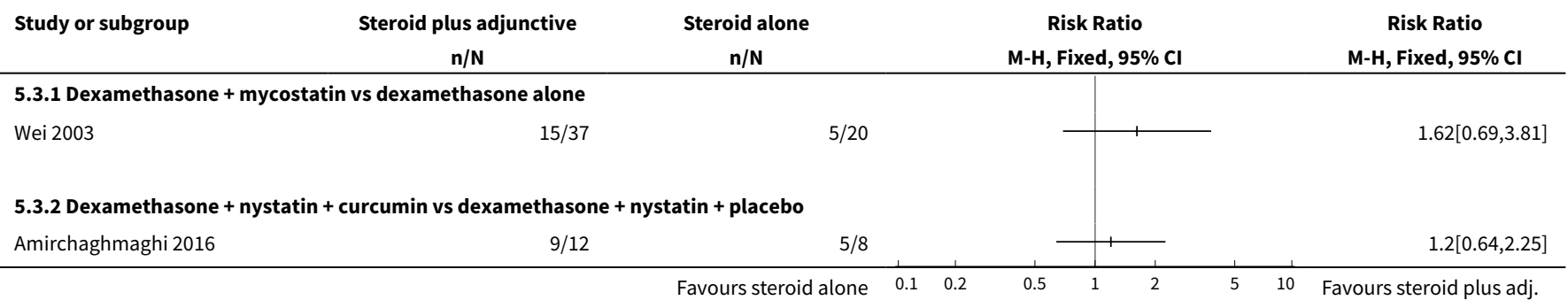

Analysis 5.4. Comparison 5 Adjunctive treatment to corticosteroids, Outcome 4 Adverse effects.

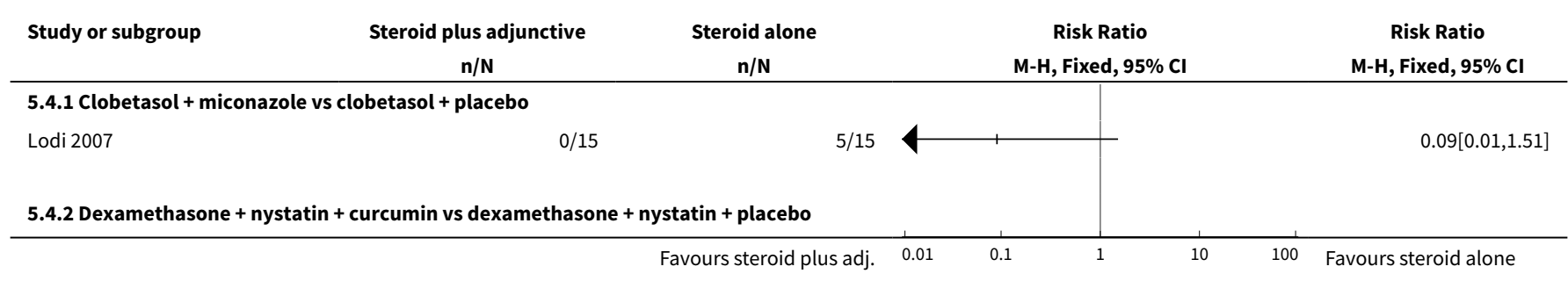




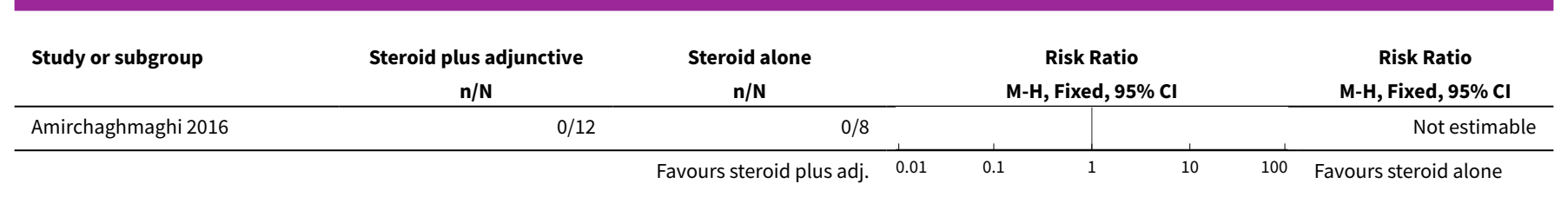

\section{ADDITIONAL TABLES}

Table 1. Characteristics of the interventions

\begin{tabular}{|c|c|c|c|}
\hline Comparison & $\begin{array}{l}\text { Delivery } \\
\text { method }\end{array}$ & Interventions & Study \\
\hline \multirow{3}{*}{$\begin{array}{l}\text { Corticos- } \\
\text { teroids vs } \\
\text { placebo }\end{array}$} & Topical & $\begin{array}{l}\text { Fluocinonide } 0.025 \% \text { in } 40 \% \text { hypromellose ointment in white soft paraffin vs place- } \\
\text { bo }\end{array}$ & Voute 1993 \\
\hline & Topical & Triamcinolone acetonide ointment $0.1 \%$ vs placebo & $\begin{array}{l}\text { Siponen } \\
2017\end{array}$ \\
\hline & Topical & Clobetasol propionate $0.025 \%$ in $4 \%$ hydroxyethyl cellulose gel vs placebo $a$ & Arduino 2018 \\
\hline \multirow{12}{*}{$\begin{array}{l}\text { Corticos- } \\
\text { teroids vs } \\
\text { calcineurin } \\
\text { inhibitors }\end{array}$} & Topical & Triamcinolone acetonide $0.1 \%$ paste vs pimecrolimus $1 \%$ paste & $\begin{array}{l}\text { Arunkumar } \\
2015\end{array}$ \\
\hline & Topical & $\begin{array}{l}\text { Clobetasol propionate } 0.025 \% \text { in } 4 \% \text { hydroxyethyl cellulose gel vs ciclosporin } 1.5 \% \\
\text { in } 4 \% \text { hydroxyethyl cellulose gel }{ }^{a}\end{array}$ & $\begin{array}{l}\text { Conrotto } \\
2006\end{array}$ \\
\hline & Topical & Clobetasol propionate $0.05 \%$ ointment vs tacrolimus $0.1 \%$ ointment & $\begin{array}{l}\text { Corrocher } \\
2008\end{array}$ \\
\hline & Topical & Betamethasone $0.1 \%$ gel vs pimecrolimus $1 \%$ gel & Ezzatt 2019 \\
\hline & Topical & Clobetasol propionate $0.05 \%$ cream vs tacrolimus $0.1 \%$ cream & $\begin{array}{l}\text { Het- } \\
\text { tiarachchi } \\
2017\end{array}$ \\
\hline & Topical & Clobetasol propionate $0.05 \%$ vs tacrolimus $0.03 \%$ & $\begin{array}{l}\text { Sivaraman } \\
2016\end{array}$ \\
\hline & Topical & Triamcinolone $0.1 \%$ paste vs pimecrolimus $1 \%$ cream & $\begin{array}{l}\text { Gorouhi } \\
2007\end{array}$ \\
\hline & Topical & Triamcinolone acetonide $0.1 \%$ in Orabase vs pimecrolimus $1 \%$ cream & $\begin{array}{l}\text { Pakfetrat } \\
2015\end{array}$ \\
\hline & Topical & $\begin{array}{l}\text { Triamcinolone acetonide } 0.1 \% \text { in hypromellose } 20 \% \text { ointment vs tacrolimus } 1 \% \\
\text { ointment }\end{array}$ & $\begin{array}{l}\text { Laeijendeck- } \\
\text { er } 2006\end{array}$ \\
\hline & Topical & Triamcinolone acetonide ointment $0.1 \%$ vs tacrolimus $0.1 \%$ ointment & $\begin{array}{l}\text { Siponen } \\
2017\end{array}$ \\
\hline & Topical & Triamcinolone acetonide $0.1 \%$ vs tacrolimus $0.03 \%$ & $\begin{array}{l}\text { Sivaraman } \\
2016\end{array}$ \\
\hline & Topical & Triamcinolone acetonide $0.1 \%$ in Orabase vs ciclosporin solution $0.1 \%$ & Yoke 2006 \\
\hline
\end{tabular}




\section{Table 1. Characteristics of the interventions (Continued)}

\begin{tabular}{|c|c|c|c|}
\hline \multirow{8}{*}{$\begin{array}{l}\text { Corticos- } \\
\text { teroid A vs } \\
\text { corticos- } \\
\text { teroid B }\end{array}$} & Topical & $\begin{array}{l}\text { Clobetasol propionate in microspheres } 0.025 \% \text { vs clobetasol propionate } 0.025 \% \text { in a } \\
\text { dispersion of a lipophilic ointment in a hydrophilic phase }\end{array}$ & $\begin{array}{l}\text { Campisi } \\
2004\end{array}$ \\
\hline & Topical & $\begin{array}{l}\text { Clobetasol priopionate } 0.05 \% \text { in } 4 \% \text { hydroxyethyl cellulose vs clobetasol priopi- } \\
\text { onate } 0.025 \% \text { in } 4 \% \text { hydroxyethyl cellulose } a\end{array}$ & $\begin{array}{l}\text { Carbone } \\
2009\end{array}$ \\
\hline & Topical & $\begin{array}{l}\text { Clobetasol propionate } 0.05 \% \text { ointment in Orabase vs triamcinolone acetonide } 0.1 \% \\
\text { ointment in Orabase }\end{array}$ & $\begin{array}{l}\text { Rodstrom } \\
1994\end{array}$ \\
\hline & Topical & Clobetasol propionate $0.05 \%$ vs triamcinolone acetonide $0.1 \%$ & $\begin{array}{l}\text { Sivaraman } \\
2016\end{array}$ \\
\hline & $\begin{array}{l}\text { Injected lo- } \\
\text { cally }\end{array}$ & $\begin{array}{l}\text { Betamethasone dipropionate } 5 \mathrm{mg} \text { + betamethasone disodium phosphate } 2 \mathrm{mg} / \mathrm{mL} \\
\text { intralesional injection vs triamcinolone acetonide } 8 \mathrm{mg} \text {, intralesional injection }\end{array}$ & Liu 2013 \\
\hline & Systemic & Betamethasone $5 \mathrm{mg}$ daily orally vs triamcinolone acetonide $0.1 \%$ paste & $\begin{array}{l}\text { Malhotra } \\
2008\end{array}$ \\
\hline & Topical & Prednisolone $5 \mathrm{mg}$ mucoadhesive tablet vs triamcinolone acetonide $0.1 \%$ paste & $\begin{array}{l}\text { Ghabanchi } \\
2009\end{array}$ \\
\hline & Topical & Fluticasone spray $50 \mu \mathrm{g}$ vs betamethasone sodium phosphate $500 \mu \mathrm{g}$ oral rinses & Hegarty 2002 \\
\hline \multirow{9}{*}{$\begin{array}{l}\text { Corticos- } \\
\text { teroids vs } \\
\text { other treat- } \\
\text { ments }\end{array}$} & Topical & Triamcinolone acetonide paste $0.1 \%$ vs curcumin paste $5 \%$ & Kia 2015 \\
\hline & Topical & $\begin{array}{l}\text { Triamcinolone acetonide paste } 0.1 \% \text { vs Curenext Oral Gel containing curcuma longa } \\
\text { extracts } 10 \mathrm{mg}\end{array}$ & $\begin{array}{l}\text { Thomas } \\
2017\end{array}$ \\
\hline & Topical & $\begin{array}{l}\text { Dexamethasone mouthwash } 0.5 \mathrm{mg} \text { oral rinses vs photodynamic therapy mediated } \\
\text { by methylene blue }\end{array}$ & $\begin{array}{l}\text { Bakhtiari } \\
2017\end{array}$ \\
\hline & Topical & Triamcinolone acetonide $0.1 \%$ paste vs hyaluronic acid preparation $0.2 \%$ paste & $\begin{array}{l}\text { Hashem } \\
2019\end{array}$ \\
\hline & Topical & $\begin{array}{l}\text { Triamcinolone acetonide } 0.1 \% \text { in Orabase vs photodynamic therapy mediated by } \\
\text { methylene blue }\end{array}$ & Mostafa 2017 \\
\hline & Topical & Triamcinolone acetonide ointment $0.1 \%$ in Orabase vs cryotherapy & Amanat 2014 \\
\hline & Topical & Clobetasol propionate gel $0.05 \%$ vs laser diodeb & $\begin{array}{l}\text { Dillenburg } \\
2014\end{array}$ \\
\hline & $\begin{array}{l}\text { Injected lo- } \\
\text { cally }\end{array}$ & $\begin{array}{l}\text { Triamcinolone acetonide } 10 \mathrm{mg} \text { intralesional injection vs Bacillus Calmette-Guerin } \\
\text { polysaccharide nucleic acid, } 0.5 \mathrm{~mL} \text { intralesional injection }\end{array}$ & Xiong 2009 \\
\hline & Topical & Dexamethasone paste $0.043 \%$ vs amlexanox paste $250 \mathrm{mg}$ & Fu 2012 \\
\hline \multirow{4}{*}{$\begin{array}{l}\text { Adjunctive } \\
\text { treatment } \\
\text { to corticos- } \\
\text { teroids }\end{array}$} & Topical & $\begin{array}{l}\text { Clobetasol propionate gel } 0.05 \%+\text { miconazole } 2 \% \text { gel vs clobetasol propionate gel } \\
0.05 \%+\text { placebo gel }\end{array}$ & Lodi 2007 \\
\hline & Topical & Dexamethasone paste and mycostatin paste alternatively vs dexamethasone paste & Wei 2003 \\
\hline & Topical & $\begin{array}{l}\text { Dexamethasone mouthwash } 0.5 \mathrm{mg} \text { oral rinses + curcumin } 250 \mathrm{mg} \text { tablets vs dexam- } \\
\text { ethasone mouthwash } 0.5 \mathrm{mg} \text { oral rinses + placebo }{ }^{b}\end{array}$ & $\begin{array}{l}\text { Amirchagh- } \\
\text { maghi } 2016\end{array}$ \\
\hline & Topical & $\begin{array}{l}\text { Triamcinolone acetonide } 0.1 \% \text { oral paste }+ \text { glucosamine sulphate } 1500 \mathrm{mg} \text { vs triam- } \\
\text { cinolone acetonide } 0.1 \% \text { oral paste }\end{array}$ & Hesen 2017 \\
\hline
\end{tabular}


Table 1. Characteristics of the interventions (Continued)

\begin{tabular}{lll} 
Systemic & Prednisone $60 \mathrm{mg}+$ curcuminoids $2000 \mathrm{mg}$ daily vs prednisone $60 \mathrm{mg}+$ placebo & $\begin{array}{l}\text { Chainani-Wu } \\
2007\end{array}$ \\
\hline Systemic & $\begin{array}{l}\text { Herbal topical and decoction + prednisone 5-10 mg 3 times daily chlorphenamine 4 } \\
\text { mg 3 times daily, vitamin C 0.1 g 3 times daily vs prednisone 5-10 mg 3 times daily, } \\
\text { chlorphenamine 4 mg 3 times daily, vitamin C 0.1g 3 times daily }\end{array}$ & Xu2 \\
&
\end{tabular}

a Participants in both groups also received antifungals: miconazole gel plus $0.12 \%$ chlorhexidine mouthrinse.

bParticipants in both groups also took antifungals: nystatin 100,000 UI/mL oral rinse.

\section{AP PE N DICES}

\section{Appendix 1. Cochrane Oral Health's Trials Register search strategy}

Cochrane Oral Health's Trials Register is available via the Cochrane Register of Studies. For information on how the register is compiled, see oralhealth.cochrane.org/trials.

From June 2013, searches of the Cochrane Oral Health Trials Register were undertaken via the Cochrane Register of Studies, using the search strategy below:

\#1 (("lichen planus" or lichen-planus or OLP):ti,ab) AND (INREGISTER)

\#2 ((mouth or oral or mucosa*):ti,ab) AND (INREGISTER)

\#3 (\#1 and \#2) AND (INREGISTER)

Previous searches of the Cochrane Oral Health Trials Register were undertaken via the Procite software, using the search strategy below:

(("lichen planus" OR lichen-planus OR OLP) AND (oral OR mucosa* OR mouth))

\section{Appendix 2. Cochrane Central Register of Controlled Trials (CENTRAL) search strategy}

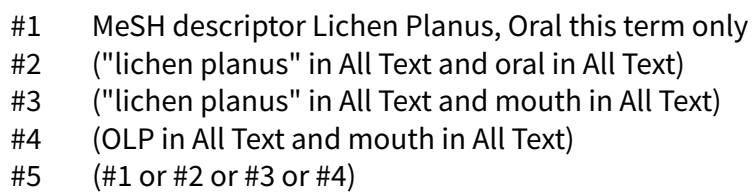

\section{Appendix 3. MEDLINE Ovid search strategy}

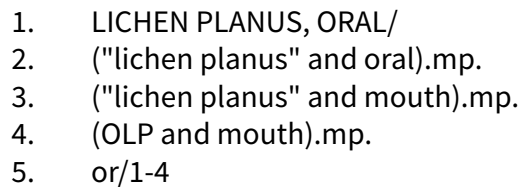

This subject search was linked to the Cochrane Highly Sensitive Search Strategy (CHSSS) for identifying randomised trials in MEDLINE: sensitivity-maximising version (2008 revision) as referenced in Chapter 6.4.11.1 and detailed in box 6.4.c of The Cochrane Handbook for Systematic Reviews of Interventions, Version 5.1.0 [updated March 2011] (Lefebvre 2011).

1. randomized controlled trial.pt.

2. controlled clinical trial.pt.

3. randomized.ab.

4. placebo.ab.

5. drug therapy.fs.

6. randomly.ab.

7. trial.ab.

8. groups.ab.

9. or/1-8

10. exp animals/ not humans.sh.

11.9 not 10 


\section{Appendix 4. Embase Ovid search strategy}

1. LICHEN PLANUS, ORAL/

2. ("lichen planus" and oral).mp.

3. ("lichen planus" and mouth).mp.

4. (OLP and mouth).mp.

5. or/1-4

The above subject search was linked to adapted version of the Cochrane Embase Project filter for identifying RCTs in Embase Ovid (see www.cochranelibrary.com/help/central-creation-details.html for information):

1. Randomized controlled trial/

2. Controlled clinical study/

3. Random\$.ti,ab.

4. randomization/

5. intermethod comparison/

6. placebo.ti,ab.

7. (compare or compared or comparison).ti.

8. ((evaluated or evaluate or evaluating or assessed or assess) and (compare or compared or comparing or comparison)).ab.

9. (open adj label).ti,ab.

10. ((double or single or doubly or singly) adj (blind or blinded or blindly)).ti,ab.

11. double blind procedure/

12. parallel group $\$ 1 . t i, a b$.

13. (crossover or cross over).ti,ab.

14. ((assign $\$$ or match or matched or allocation) adj5 (alternate or group $\$ 1$ or intervention $\$ 1$ or patient $\$ 1$ or subject $\$ 1$ or participant

\$1)).ti,ab.

15. (assigned or allocated).ti,ab.

16. (controlled adj7 (study or design or trial)).ti,ab.

17. (volunteer or volunteers).ti,ab.

18. trial.ti.

19. or/1-18

20. (exp animal/ or animal.hw. or nonhuman/) not (exp human/ or human cell/ or (human or humans).ti.)

21. 19 not 20

\section{Appendix 5. ClinicalTrials.gov search strategy}

"oral lichen planus"

Appendix 6. WHO International Clinical Trials Registry Platform search strategy

"oral lichen planus"

WHAT'S NEW

\begin{tabular}{lll}
\hline Date & Event & Description \\
\hline 17 August 2019 & $\begin{array}{l}\text { New citation required and conclusions } \\
\text { have changed }\end{array}$ & $\begin{array}{l}\text { We identified three placebo-controlled trials (the last version of } \\
\text { the review had none) and found low-certainty evidence that top- } \\
\text { ical corticosteroids may be more effective than placebo for re- } \\
\text { ducing the pain of oral lichen planus. }\end{array}$ \\
& $\begin{array}{l}\text { We found very low-certainty evidence that tacrolimus may re- } \\
\text { duce pain more than clobetasol, but also that tacrolimus may be } \\
\text { more likely to cause adverse effects. }\end{array}$ \\
\end{tabular}

26 February $2019 \quad$ New search has been performed

Review split into two: one focusing on corticosteroid therapies and one focusing on non-corticosteroid therapies.

Updated searches

14 new studies included 


\section{HISTORY}

Protocol first published: Issue 3, 1998

Review first published: Issue 2, 1999

\begin{tabular}{lll}
\hline Date & Event & Description \\
\hline 14 June 2011 & $\begin{array}{l}\text { New citation required and conclusions } \\
\text { have changed }\end{array}$ & $\begin{array}{l}\text { Significant update of original review published in 1999: new re- } \\
\text { view team; review methodology updated; included studies in- } \\
\text { creased from } 9 \text { to 28. }\end{array}$ \\
\hline 14 June 2011 & New search has been performed & Searches updated to 26 January 2011. \\
\hline 18 June 2008 & New search has been performed & Converted to new review format. \\
\hline
\end{tabular}

\section{CONTRIBUTIONS OF AUTHORS}

GL: main review author, participation in all phases of the review's preparation.

MM: participation in all phases of the review's preparation.

VM: selection of eligible trials, risk of bias assessment and data extraction, manuscript preparation.

MC: selection of eligible trials, interpretation of results, manuscript preparation.

\section{DECLARATIONS OF INTEREST}

GL: none known. I am an Editor with Cochrane Oral Health. I authored one of the included studies (Lodi 2007).

MM: none.

VM: none.

RM: none.

MC: the institution I work for received money from a company called AFYX for a study on a new preparation of clobetasol, which may be included in a future update of this review (NCT03592342).

\section{SOURCES OF SUPPORT}

\section{Internal sources}

- Cochrane Oral Health, UK.

Provided funding for a meeting held in Italy in 2009

- School of Dentistry, The University of Manchester, Manchester Academic Health Sciences Centre (MAHSC) and the NIHR Manchester Biomedical Research Centre, UK.

\section{External sources}

- Cochrane Oral Health Global Alliance, Other.

The production of Cochrane Oral Health reviews has been supported financially by our Global Alliance since 2011 (oralhealth.cochrane.org/partnerships-alliances). Contributors in the last two years have been the American Association of Public Health Dentistry, USA; AS-Akademie, Germany; the British Association for the Study of Community Dentistry, UK; the British Society of Paediatric Dentistry, UK; the Canadian Dental Hygienists Association, Canada; the Centre for Dental Education and Research at All India Institute of Medical Sciences, India; the National Center for Dental Hygiene Research \& Practice, USA; New York University College of Dentistry, USA; and Swiss Society of Endodontology, Switzerland.

- National Institute for Health Research (NIHR), UK.

This project was supported by the NIHR, via Cochrane Infrastructure funding to Cochrane Oral Health. The views and opinions expressed therein are those of the authors and do not necessarily reflect those of the Systematic Reviews Programme, NIHR, NHS or the Department of Health. 


\section{DIFFERENCES BETWEEN PROTOCOLAND REVIEW}

We have split the original review into two: this one focusing on corticosteroid therapies, and another, which in preparation, focusing on non-corticosteroid therapies. As a result, some of the trials included in the last version have been removed from this update and will appear in the sister review update.

Some of our 'Risk of bias' judgements have changed from the last version after our reconsideration; for example, we judged blinding more strictly and separated out performance and detection bias.

In addition to integrating the new results into the review, we edited and updated the Background; Methods; and Discussion sections.

\section{NOTES}

This is part of an update of a review originally published in 1999 (Chan 1999), and first updated in 2011 (Thongprasom 2011). We have split the review into two: one on corticosteroid therapies (this review), and another on non-corticosteroid therapies (in preparation).

\section{INDEX TERMS}

\section{Medical Subject Headings (MeSH)}

*Palliative Care; Aloe; Calcineurin Inhibitors; Cyclosporins [therapeutic use]; Lichen Planus, Oral [`therapy]; Mouthwashes; Phototherapy; Plant Preparations [therapeutic use]; Randomized Controlled Trials as Topic; Retinoids [therapeutic use]; Steroids [therapeutic use]

\section{MeSH check words}

Humans 